\title{
Geological, Geochemical, and Geophysical Studies by the U.S. Geological Survey in Big Bend National Park, Texas
}

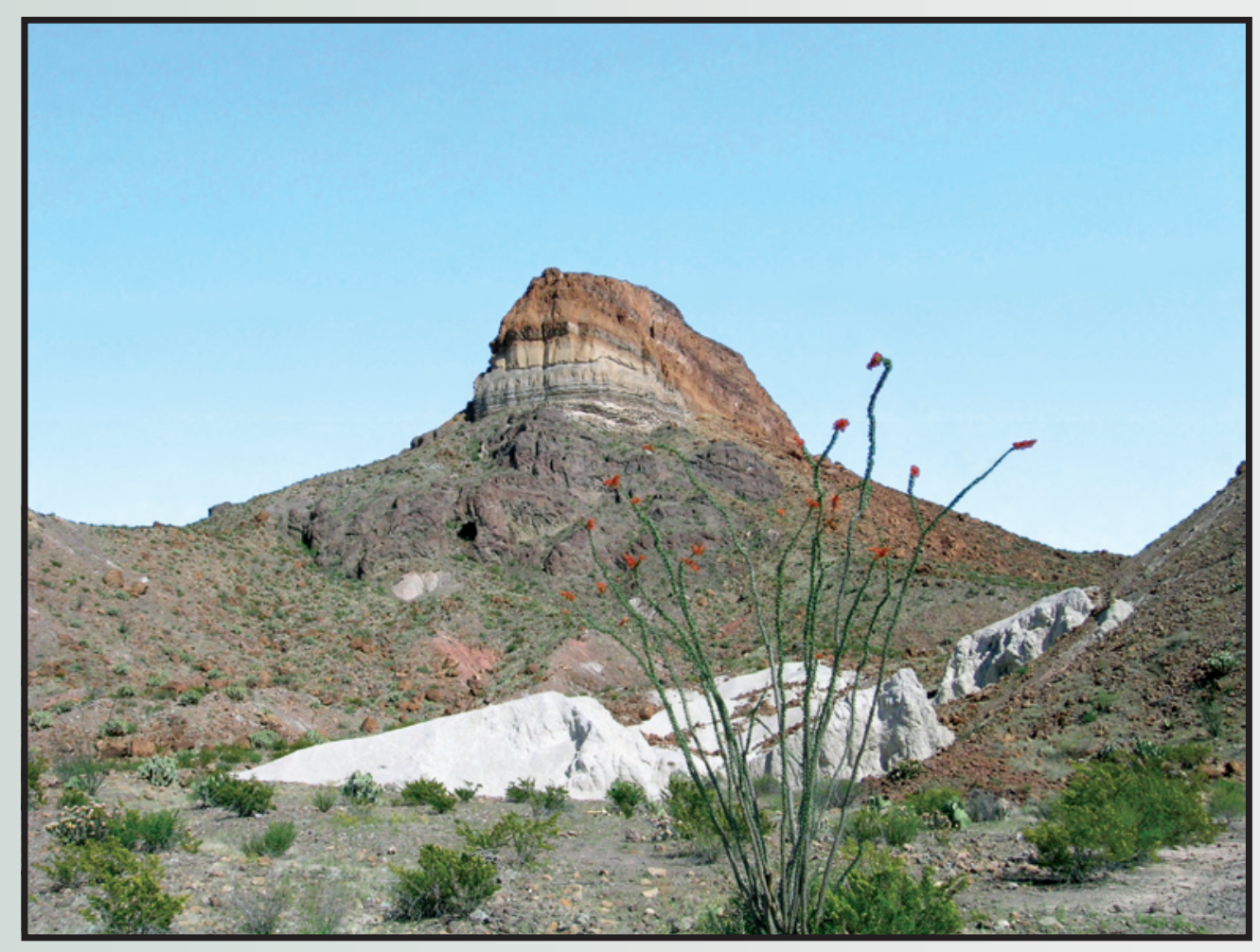

Circular 1327

U.S. Department of the Interior U.S. Geological Survey

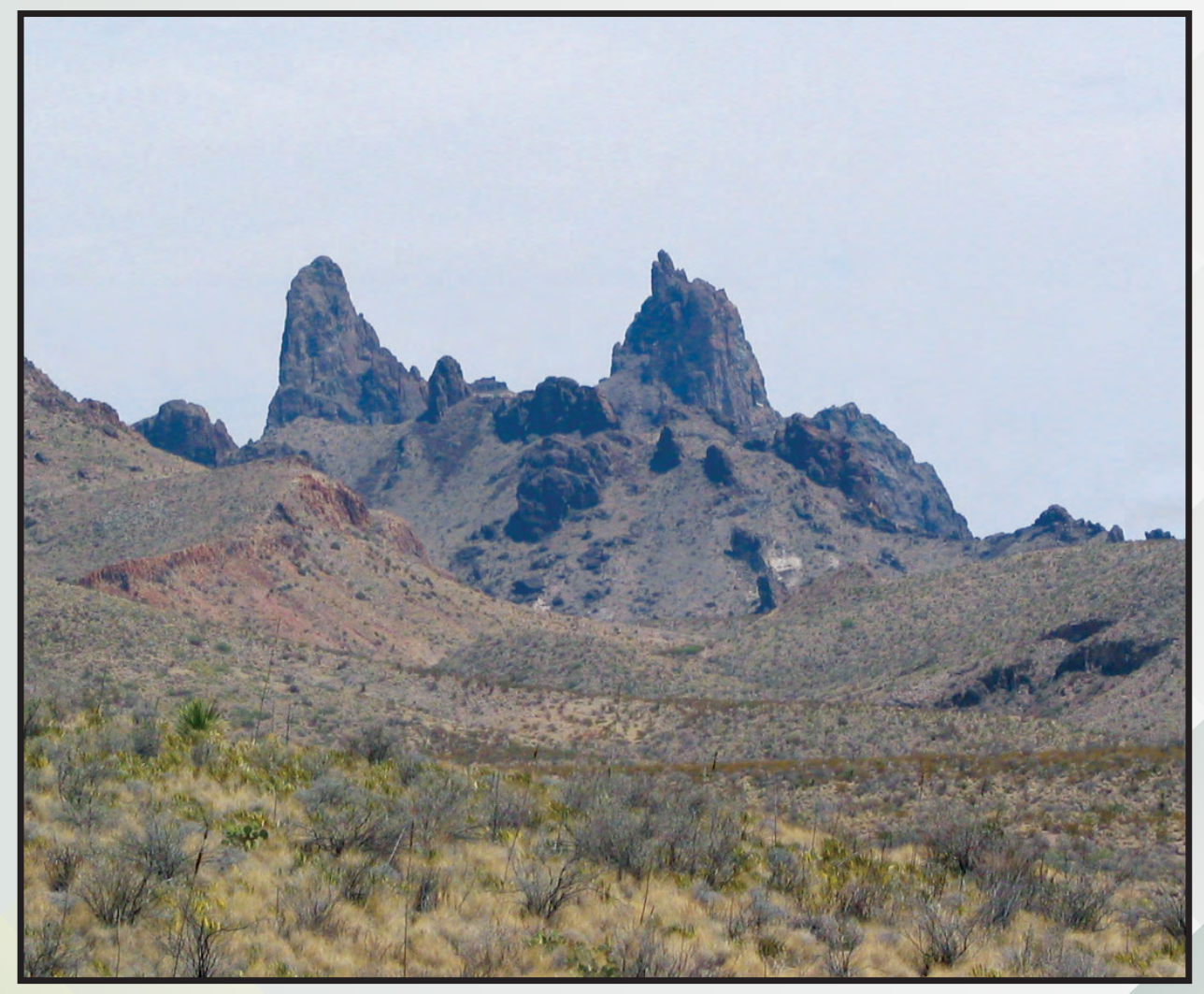


Cover photographs. Front upper: View looking west at Cerro Castellan located northeast of the village of Castolon in Big Bend National Park. This exposure is a series of Tertiary age volcanic units. In the foreground are white outcrops of Tertiary age tuffaceous sedimentary deposits and an ocotillo cactus. Photo by David L. Fey. Front lower: View looking east toward Mule Ear Peaks, which are eroded rhyolitic units of Tertiary age. Photo by John E. Gray. Back cover: View looking west through "The Window" located in The Basin of Big Bend National Park. The Window is a narrow opening between intrusive rocks of Ward Mountain and Pulliam Peak. Runoff and drainage from The Basin flows through The Window and downstream into Oak Creek. Photo by John E. Gray. 


\section{Geological, Geochemical, and Geophysical Studies by the U.S. Geological Survey in Big Bend National Park, Texas}

Edited by J.E. Gray and W.R. Page

Circular 1327 


\title{
U.S. Department of the Interior DIRK KEMPTHORNE, Secretary
}

\author{
U.S. Geological Survey \\ Mark D. Myers, Director
}

U.S. Geological Survey, Reston, Virginia: 2008

For product and ordering information:

World Wide Web: http://www.usgs.gov/pubprod

Telephone: 1-888-ASK-USGS

For more information on the USGS — the Federal source for science about the Earth,

its natural and living resources, natural hazards, and the environment:

World Wide Web: http://www.usgs.gov

Telephone: 1-888-ASK-USGS

\footnotetext{
Any use of trade, product, or firm names is for descriptive purposes only and does not imply endorsement by the U.S. Government.

Although this report is in the public domain, permission must be secured from the individual copyright owners to reproduce any copyrighted material contained within this report.
}

Suggested citation:

Gray, J.E., and Page, W.R., eds., 2008, Geological, geochemical, and geophysical studies by the U.S. Geological Survey in Big Bend National Park, Texas: U.S. Geological Survey Circular 1327, 93 p. 


\section{Foreword}

A key goal of the work of the U.S. Geological Survey (USGS) is to enhance and protect the quality of life by describing and understanding the Earth around us. This Circular describes work that is part of ongoing collaborative studies-involving the USGS, National Park Service, the Texas Bureau of Economic Geology, and several universities-of the composition, history, and age of the rocks that underlie Big Bend National Park in southwest Texas.

Big Bend National Park, located along the Rio Grande at the United States border with Mexico, is situated in the Chihuahuan Desert. The fragile desert ecosystem displays enormous beauty, includes mountain and basin environments, hosts an extraordinary diversity of native plants and animals, and is the site of significant mineral deposits and historic mercury mines. The studies reported in this Circular were largely funded by the USGS Mineral Resources and National Cooperative Geologic Mapping Programs. The scientists who conduct the work of these programs provide new information for uses ranging from understanding sources and effects of nonfuel mineral deposits to improving management of Federal lands.

The eight technical papers included in this Circular present a range of studies and results. Taken as a whole, the new geologic mapping and geophysical data, together with analyses of surface and subsurface waters, abandoned mine sites, and food sources of large mammals, provide a fundamental and objective scientific foundation for land-use, water-use, and resource-use decision makers in and near Big Bend National Park. In addition, geochemical studies of miningrelated mercury contamination in and around the park address a specific local challenge by demonstrating that, although mercury concentrations are elevated in mine waste, concentrations are generally low in the downstream ecosystems, primarily because of hot and dry desert climate conditions of the region. These diverse scientific studies conducted in Big Bend National Park not only inform decisions there, but also provide a basis for understanding similar environments elsewhere in the United States and around the world.

Kathleen M. Johnson

Mineral Resources Program Coordinator 


\section{Contents}

Foreword, by K.M. Johnson ..................................................................................................

Introduction, by J.E. Gray and W.R. Page ...............................................................................

1. Tectonic History of Big Bend National Park, by W.R. Page, K.J. Turner, and

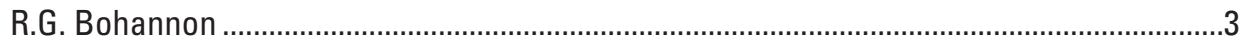

2. Surficial Deposits of Big Bend National Park, by M.E. Berry and V.S. Williams.......................15

3. Volcanic Geology of Several Prominent Outcrops in the Western Part of Big Bend National Park, by D.P. Miggins, M. Ren, and E.Y. Anthony.

4. Where Magma Meets Limestone: Dagger Flats, an Example of Skarn Deposits in Big

Bend National Park, by L.A. Morgan and W.C. Shanks

5. Evaluation of Mercury Contamination at Inactive Mercury Mines in and around Big Bend National Park, by J.E. Gray, P.M. Theodorakos, and D.P. Krabbenhoft......................57

6. The Waters of Big Bend: Geochemical Variations, Ages, and Sources, by W.C. Shanks, L.A. Morgan, J.E. Gray, A.H. Manning, and P.A. Gemery-Hill

7. Stable Isotope and Trace Element Studies of Black Bear Hair, Big Bend Ecosystem, Texas and Mexico, by W.C. Shanks, E.C. Hellgren, C. Stricker, P.A. Gemery-Hill, and D.P. Onorato.

8. Aeromagnetic and Radioelement Analyses Identify Igneous Rocks in the Big Bend National Park Region, by C.A. Finn and E. Anderson ...

\section{Figures}

1-1. Map of BBNP showing late Tertiary Basin and Range faults, middle Tertiary volcanic and plutonic features, and present-day distribution of generalized rock units.

1-2. Index map showing transform faults and lineaments related to Proterozoic rifting along the southern edge of North America.

1-3. Map showing location of Marathon orogenic belt and subduction zone formed from collision between the North and South American plates.

1-4. Stratigraphic column showing geologic rock units and major tectonic episodes in Big Bend National Park

1-5. Map showing location of the Diablo Platform and the Chihuahua trough........................9

1-6. Generalized map of the major structures that formed in BBNP during the Laramide orogeny

2-1. Map showing locations within Big Bend National Park that are referred to in the text.

2-2. Photograph taken near Estufa Spring, looking east (downstream) towards the boundary fault and sediments of Estufa bolson

2-3. Example of the strong calcic soil typical of Qoa deposits in Big Bend National Park....20

2-4. Examples of pediment sequences in Big Bend National Park......................................22

2-5. Rio Grande terraces near Santa Elena Canyon Overlook, southwest Big Bend National Park

2-6. Banded vegetation and surface characteristics of deposits on which the banded

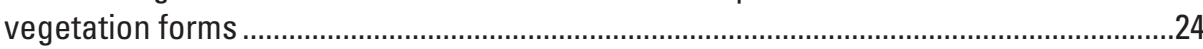

3-1. Landsat 7 image showing Big Bend National Park and surrounding regions.

3-2. Location map and stratigraphic composite section for the Chisos Group and South Rim Formations 
3-3. Total alkali versus silica diagram showing the major rock types discussed in the text.

3-4. Landsat 7 image of the western half of Big Bend National Park indicating some of the major features and geologic units discussed in the text. .34

3-5. Various photos and composite stratigraphic section for the Blue Creek Ranch area ...36

3-6. Photo of Tule Mountain indicating the major volcanic rocks exposed in the area .........37

3-7. Photos showing distant and close up views for the stratigraphy of the Round Mountain area located south of the Mule Ears Viewpoint. .38

3-8. Location map and photos showing the stratigraphy of Cerro Castellan .........................39

3-9. Various photos showing the Bee Mountain Basalt above the Mule Ear Spring Tuff......40

4-1. Index maps and photo of study area in Big Bend National Park and at Dagger Flats....44

4-2. Geologic and magnetic intensity maps of the Dagger Flats vicinity . .45

4-3. Series of photographs of composite sills exposed in the Dagger Flats area and their range in composition

4-4. Four diagrams from various sites at Dagger Flats where schematic stratigraphic sections are compared with variation in content of $\mathrm{SiO}_{2}, \mathrm{CaO}$, and $\mathrm{Al}_{2} \mathrm{O}_{3}$ and with changes in depth in the capping mineralized limestone units above the sill. Also compared are alteration mineralogies for the skarn and sills.....

4-5. Photographs of features exposed in skarns at Big Bend National Park .51

4-6. Simplified schematic diagrams illustrating a model for the intrusion of sills at Dagger Flats into the Cretaceous Boquillas Formation and formation of the skarn .......52

5-1. Location of the study area and mercury mines studied ...................................................58

5-2. Photographs of Study Butte and Mariscal mercury mines and mine waste...................60

5-3. Concentration of mercury in mine waste and sediment collected in and around Big Bend National Park

5-4. Concentration of mercury versus methylmercury in water collected in the Big Bend area.

5-5. Mercury concentrations in air and soil gas collected from mercury mines in the Big Bend area and from uncontaminated baseline sites in the park

6-1. Location of Big Bend water samples from springs, streams, and drinking water wells

6-2. Oxygen and hydrogen composition of Big Bend waters.

6-3. Chemical variation diagrams for selected constituents that illustrate fundamental differences between waters from different areas

6-4. Geologic setting of drinking water production sites in Big Bend National Park .............72

6-5. Photograph of vertical fractures (joints) in the Ward Mountain rhyolitic intrusive rocks east of Ward Spring.

7-1. Black bear in Big Bend National Park..............................................................................78

7-2. Map showing general location of the Big Bend ecosystem where black bear hair samples were collected for this study

7-3. Plots of nitrogen isotopes versus carbon and sulfur isotope values for Big Bend black bear hair

8-1. Magnetic anomaly and magnetic sources from the Big Bend National Park region .....86

8-2. Magnetic data superimposed on an aerial photo draped on a DEM along the south central portion of the Chalk Draw Fault.

8-3. Mapped faults superimposed on the maxima of the horizontal gradient of the reduced to the pole magnetic anomaly

8-4. Color composite of potassium, thorium, and uranium superimposed on a grey shade map of the topography, with outlines of selected geologic units 


\section{Tables}

2-1. Age estimates for time divisions within the Tertiary and Quaternary Periods .................17

2-2. Surficial deposits in Big Bend National Park............................................................17

2-3. Rio Grande terraces and their general correlation to other alluvial deposits in

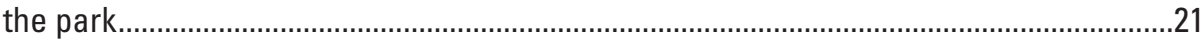

6-1. Helium-tritium and rare gas results .........................................................................

7-1. Stable isotope data for bear hair in the Big Bend National Park area .............................81

7-2. Average composition and standard deviation of selected elements in Big Bend National Park bear hair 


\title{
Introduction
}

\author{
By J.E. Gray and W.R. Page
}

Big Bend National Park (BBNP), Tex., covers 801,163 acres (3,242 km²) and was established in 1944 through a transfer of land from the State of Texas to the United States. The park is located along a 118-mile (190-km) stretch of the Rio Grande at the United States-Mexico border. The park is in the Chihuahuan Desert, an ecosystem with high mountain ranges and basin environments containing a wide variety of native plants and animals, including more than 1,200 species of plants, more than 450 species of birds, 56 species of reptiles, and 75 species of mammals. In addition, the geology of BBNP, which varies widely from high mountains to broad open lowland basins, also enhances the beauty of the park. For example, the park contains the Chisos Mountains, which are dominantly composed of thick outcrops of Tertiary extrusive and intrusive igneous rocks that reach an altitude of 7,832 $\mathrm{ft}(2,387 \mathrm{~m})$ and are considered the southernmost mountain range in the United States. Geologic features in BBNP provide opportunities to study the formation of mineral deposits and their environmental effects; the origin and formation of sedimentary and igneous rocks; Paleozoic, Mesozoic, and Cenozoic fossils; and surface and ground water resources. Mineral deposits in and around BBNP contain commodities such as mercury (Hg), uranium (U), and fluorine (F), but of these, the only significant mining has been for $\mathrm{Hg}$. Because of the biological and geological diversity of BBNP, more than 350,000 tourists visit the park each year.

The U.S. Geological Survey (USGS) has been investigating a number of broad and diverse geologic, geochemical, and geophysical topics in BBNP to provide fundamental information needed by the National Park Service (NPS) to address resource management goals in this park. Scientists from the USGS Mineral Resources and National Cooperative Geologic Mapping Programs have been working cooperatively with the NPS and several universities on several research studies within BBNP. Because the last geologic map of the entire BBNP was published in the 1960s, one of the primary goals of the USGS is to provide a new geologic map of BBNP at a scale 1:100,000; this work is ongoing among the USGS, NPS, the Texas Bureau of Economic Geology, and university scientists. This USGS Circular summarizes eight studies funded and primarily carried out by the USGS, but it is not intended to be a comprehensive reference of work conducted in BBNP. This Circular describes topical research of the recently completed interdisciplinary USGS project, which has provided information leading to a more complete understanding of the following topics in BBNP:

- Tectonic and geologic history (Chapters 1, 2, and 3),

- Age and formation processes of a skarn mineral deposit (Chapter 4),

- Geoenvironmental effects of abandoned mercury mines (Chapter 5),

- Age, source, and geochemistry of surface and subsurface water resources (Chapter 6),

- Isotopic tracing of food sources of bears (Chapter 7), and

- Geophysical characteristics of surface and subsurface geology (Chapter 8).

Additional information and the geochemical and geophysical data of the USGS studies in BBNP are available on line at http://minerals.cr.usgs.gov/projects/big_bend/index.html. 



\title{
1. Tectonic History of Big Bend National Park
}

\author{
By William R. Page, Kenzie J. Turner, and Robert G. Bohannon
}

\section{Abstract}

Geologic features in Big Bend National Park (BBNP) formed from repetitive cycles of rifting, mountain building, basin development, faulting and folding, and volcanism and plutonism. The oldest tectonic episode recorded in the park is mountain building associated with the Marathon orogeny, which deformed the rocks in the park region from Middle Mississippian to Early Permian time (about 330-285 Ma). During this episode, deep ocean basin rocks originally deposited south of BBNP were thrust northwestward onto the edge of the North American continent by collision between the North and South American plates.

From the Late Triassic into the Late Cretaceous (about 200-85 Ma), the BBNP area experienced subtle effects of rifting between the North and South American continents; this rifting largely controlled the opening of the Gulf of Mexico. During rifting, BBNP was part of the Diablo Platform, a carbonate platform where the sediments that would become Lower and Upper Cretaceous limestone and shale units were deposited in shallow, open-marine water.

The Late Cretaceous to early Tertiary Laramide orogeny (about 70-50 Ma) had significant influence on the tectonic evolution of BBNP. This period of contractional deformation produced major uplifts, basins, and faults and folds that formed from northeast-directed compression related to collision between the North American continent and the Pacific/ Farallon plate at the western edge of the continent. Major Laramide features in BBNP include the northeast-facing Mesa de Anguila, an uplifted monocline on the southwest margin of the park, and the southwest-facing Sierra del Carmen-Santiago Mountains, an uplifted and thrusted monocline bounding the east part of the park. The Tornillo Basin developed between these uplifted basin margins.

Major episodes of volcanism and plutonism occurred in the park area from about 46 to $28 \mathrm{Ma}$. Principal features formed in this time period include numerous volcanic flows extruded from a complex system of volcanic vents and lava domes in the western part of the park and adjacent areas of Mexico, and the Pine Canyon caldera complex, which constitutes the high Chisos Mountains. It was during this time that major laccolithic complexes developed and intruded Cretaceous and Tertiary sedimentary rocks to form the Rosillos Mountains, McKinney Hills, and Grapevine Hills. These volcanic features, especially The Basin area of the Chisos Mountains, are some of the most visited and scenic parts of the park.
The last major tectonic episode to affect BBNP was Basin and Range faulting from about 25 to $2 \mathrm{Ma}$. Features formed in BBNP during this time period include mostly high-angle normal faults that cut the entire stratigraphic sequence through Pliocene basin-fill deposits. Movement on some of the major faults has formed local depositional basins, such as the Estufa and Delaho bolsons on the flanks of the high Chisos Mountains. Basin and Range faults predated integration of the late Tertiary basins with the Rio Grande, which began about $2 \mathrm{Ma}$, and they were the last structures to modify the landscape into its present-day configuration.

\section{Introduction}

This report is a brief overview of the salient aspects of the tectonic history of BBNP. A more thorough review of the state of knowledge of tectonism for the BBNP area is beyond the scope of this report. The report does provide the reader with key references that address the tectonic history of BBNP and adjacent areas in greater detail. Muehlberger $(1980,1989)$ and Muehlberger and Dickerson (1989) reviewed the tectonic history of the Trans-Pecos Texas region, including the $\mathrm{BBNP}$ area, related to the pervasive influence of preexisting structural grain on the development of later tectonic features. Dickerson (1980) summarized the tectonic history of the Trans Pecos region in terms of major structural zones, which were reactivated by structures of different regional stress regimes throughout time. Lehman (1991) and Lehman and Busbey (2007) provided summaries of Laramide and Neogene tectonism in BBNP based on detailed sedimentation studies. The early work of Maxwell and others (1967) provided an impressive, detailed account of the tectonic history and major structural features specific to BBNP. These reports, in addition to those referenced below, serve as a foundation for understanding the complex tectonic history of the BBNP region.

\section{Proterozoic Rifting}

Although the oldest recorded tectonism in BBNP is related to the late Paleozoic Marathon orogeny, Proterozoic rifting and protocontinental plate collisional events likely had 
a profound influence in shaping BBNP's landscape. These older events are thought to have established the northwest trend of major structural and geographic features that characterize the park today (fig. 1-1) (Muehlberger, 1980).

Neoproterozoic rifting (about 800-550 Ma) along the southern edge of the North American continent produced northwest-striking continental transform faults that laterally offset the southern continental margin (fig. 1-2) (Thomas, 1991; Poole and others, 2005). Poole and others (2005) reported that these faults controlled the geometry and configuration of the Ouachita-Marathon-Sonora orogenic belt; figure 1-3 illustrates how these older faults define major northwestto-southwest bends in the Marathon belt that mimic transform fault offset patterns.

The transform faults are subparallel with the Texas lineament (Albritton and Smith, 1957; Muehlberger, 1980), a northwest-trending zone of proposed wrench faulting extending from Presidio, Tex., southward into the Big Bend area (fig. 1-2). Muehlberger (1980) and Dickerson (1980) suggested that faults related to the deeply buried Texas lineament may have formed during rifting events as long ago as 1,500-1,000 Ma, and the fault zone was reactivated during subsequent tectonic episodes, including the late Paleozoic Marathon orogeny, Late Cretaceous-early Tertiary Laramide orogeny, and late Tertiary Basin and Range faulting. Some of the major northwest-trending features in BBNP include the Sierra del Carmen-Santiago Mountains and the Mesa de Anguila monoclinal uplifts, and numerous northwest striking faults and folds (fig. 1-1).

\section{Paleozoic}

During its early history (Paleozoic), BBNP was near the southern edge of the North American continent and was the site of marine deposition and complex tectonic interactions between the North and South American plates. The oldest tectonic episode recorded in the park is mountain building associated with the Marathon orogeny, which deformed rocks in the BBNP region from Middle Mississippian to Early Permian time (about 330-285 Ma; fig. 1-3) (Poole and others, 2005). The Marathon orogenic belt is one segment of the much larger Ouachita-Marathon-Sonora orogenic belt of Poole and others (2005), which extends along the Paleozoic continental margin from Mississippi and Arkansas (Ouachita segment), through Texas (Marathon segment), and into Chihuahua and Sonora, Mexico (Sonora segment).

In the west Texas area, deep-water ocean basin rocks originally deposited south of the Big Bend area were thrust northwestward onto the North American continent above a subduction zone created by the collision between the North and South American plates (fig. 1-3). Along this zone, the subducting slab of North American continental crust plunged southeast below the overriding South American plate. Paleozoic rocks of the Marathon belt are well exposed to the north of BBNP in the Marathon Basin (Wilson, 1954; Muehlberger and Tauvers, 1989) where they are deformed by northeaststriking, northwest-vergent thrust faults and folds.

Only remnants of the Marathon orogeny can be seen in BBNP's present-day landscape; these remnants are characterized by small outcrop belts (fig. 1-1) containing Paleozoic rocks and northwest-directed thrust faults. Paleozoic rocks of the Marathon orogeny are best exposed in the Persimmon Gap area of the park (fig. 1-3) (Maxwell and others, 1967) and include, from base to top, the Middle Ordovician Maravillas Formation, Silurian to Mississippian Caballos Novaculite, and the Mississippian to Pennsylvanian Tesnus Formation (fig. 1-4) (Poole and others, 2005). Northwest-vergent thrust faults duplicate the Paleozoic section and juxtapose rocks of the Maravillas Formation above the Tesnus Formation (Maxwell and others, 1967; Poth, 1979). The Paleozoic thrust block at Persimmon Gap was subsequently deformed during the Late Cretaceous-early Tertiary Laramide orogeny (see below) by southwest-vergent thrust faults, which juxtaposed the Paleozoic thrust block with Cretaceous sedimentary rocks above and below (Maxwell and others, 1967; Poth, 1979).

The Maravillas Formation and Caballos Novaculite are interpreted as pre-orogenic, deep-water basinal rocks (McBride, 1989; Noble, 1994; Page and Harris, 2007), and the Tesnus Formation is interpreted as synorogenic flysch deposited into foreland basins in front of the advancing Marathon thrust sheet (Poole and others, 2005). The Marathon orogenic highlands slowly eroded during Triassic and Jurassic Periods. The absence of Triassic- and Jurassic-age rocks in BBNP reflects this period of erosion, which is characterized locally in the park by a major unconformity separating rocks of the Lower Cretaceous Glen Rose Limestone above from rocks of the Mississippian-Pennsylvanian Tesnus Formation below (fig. 1-4).

\section{Mesozoic-Cenozoic}

\section{Triassic-Cretaceous Rifting}

From the Late Triassic into the Late Cretaceous (about 200-85 Ma), the BBNP area experienced subtle affects of rifting, or seafloor spreading, between North and South America; this rifting controlled the opening of the Gulf of Mexico (Muehlberger, 1980; Muehlberger and Dickerson, 1989; Lehman and Busbey, 2007). During rifting, BBNP was part of the Diablo Platform (fig. 1-5) (Henry, 1998; Goldhammer and Johnson, 1999), where sediments of Lower and Upper Cretaceous limestone and shale units were deposited in shallow open-marine water. These units include, from base to top, the Glen Rose Limestone, Del Carmen Limestone, Sue Peaks Formation, Santa Elena Limestone, Del Rio Clay, Buda Limestone, and Boquillas Formation (fig. 1-4), and are preserved today mostly in the Sierra del Carmen-Santiago Mountains, Nine Point Mesa, Mariscal Mountain, and Mesa de Anguila areas of the park (fig. 1-1). 


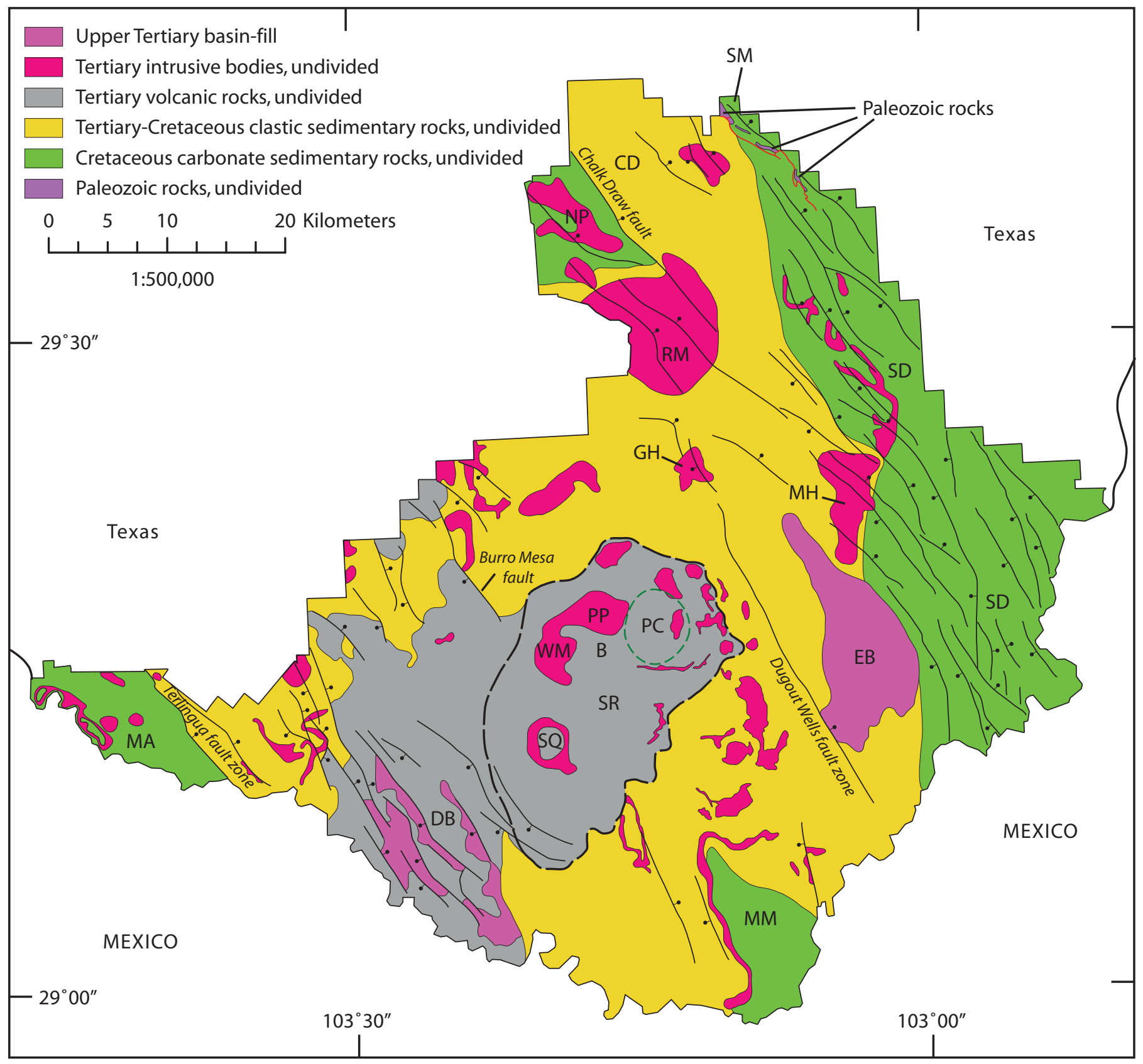

Figure 1-1. Map of BBNP showing late Tertiary Basin and Range faults (last major tectonic episode in BBNP), middle Tertiary volcanic and plutonic features, and present-day distribution of generalized rock units (colors). Geologic features are designated by upper case letters and include: SM, Santiago Mountains; CD, Chalk Draw graben; NP, Nine Point Mesa; RM, Rosillos Mountains; SD, Sierra del Carmen; GH, Grapevine Hills; MH, McKinney Hills; EB, Estufa bolson; MM, Mariscal Mountain; PC, Pine Canyon caldera; B, The Basin; PP; Pulliam Peak; WM, Ward Mountain; SR, South Rim; SQ, Sierra Quemada; DB, Delaho bolson; and MA, Mesa de Anguila. Thick black dashed line in central part of figure is outline of Chisos Mountains; green dashed line is Pine Canyon caldera. Solid black lines with bar and ball are late Tertiary Basin and Range faults; bar and ball is on downthrown side. 
Figure 1-2. Index map showing transform faults and lineaments related to Proterozoic rifting along the southern edge of North America. Solid black lines are Neoproterozoic continental transform faults (Poole and others, 2005; Thomas, 1991); arrows show relative motion of continental plate offset; gray double-banded line is main rift zone between North and South American plates; solid red lines are Texas lineament (Albritton and Smith, 1957; Muehlberger, 1980); and dark green area is BBNP.

Figure 1-3. Map showing location of Marathon orogenic belt and subduction zone (inset figure) formed from collision between the North and South American plates. Dotted black lines are traces of transform faults shown in figure 1-2; short solid red line represents approximate line of section for inset figure; dark green area is BBNP; PG, Persimmon Gap.
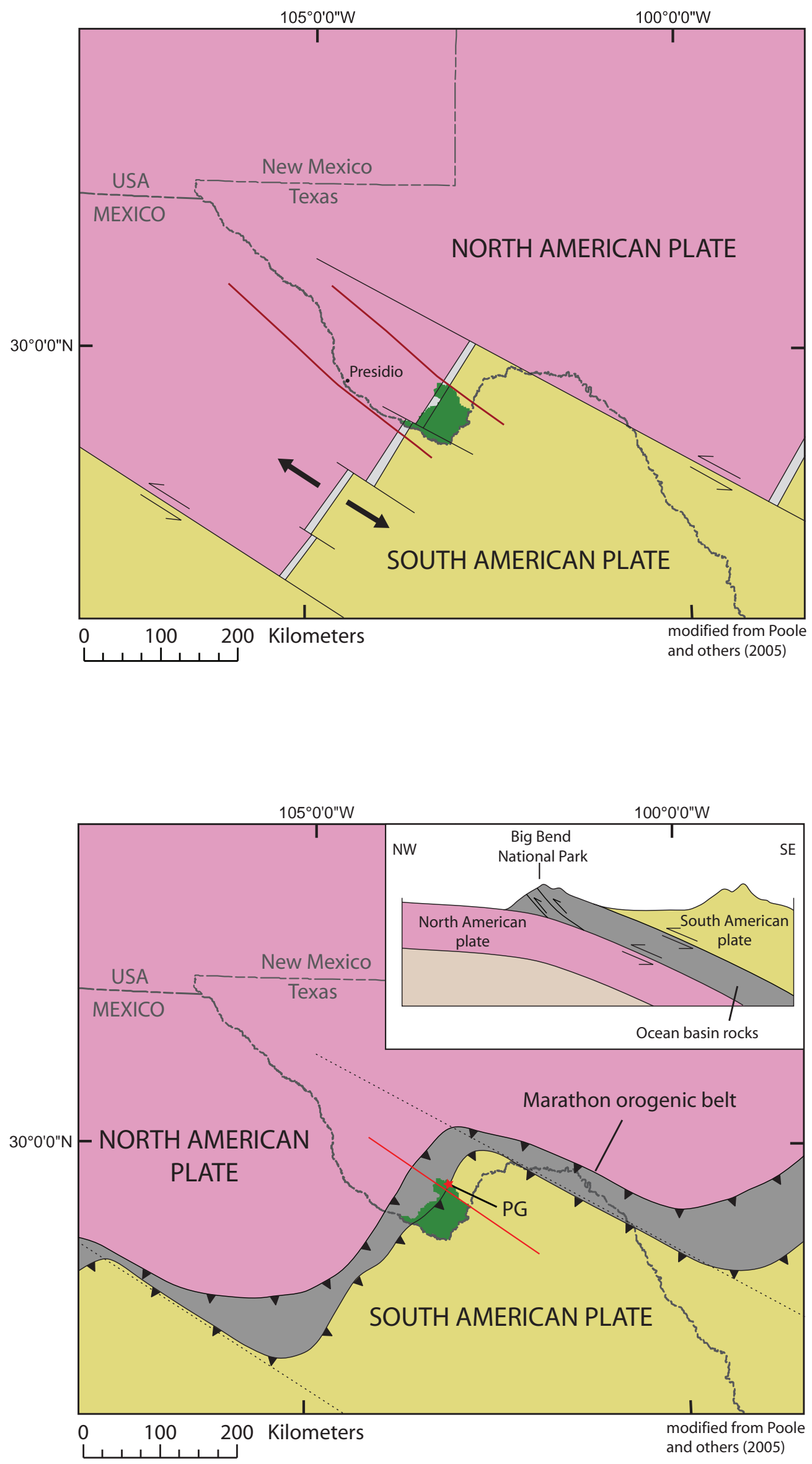
Southwest of the platform, an ocean basin known as the Chihuahua trough formed in association with the opening of the Gulf of Mexico (fig. 1-5) (Muehlberger, 1980; Muehlberger and Dickerson, 1989; and Lehman and Busby, 2007). Development of the trough resulted from Late Triassic rifting, and faulting along its margin with the Diablo Platform controlled subsidence of the trough from the Jurassic to Late Cretaceous time (fig. 1-5) (Lehman and Busbey, 2007). Cretaceous rocks in the Chihuahua trough are much thicker than time-equivalent rocks of the Diablo Platform. Lehman and Busbey (2007) reported that trough rocks of the Ojinaga Formation (found outside of BBNP) are about six times thicker than equivalent platform rocks of the Boquillas Formation in BBNP.

Deposition of the Upper Cretaceous Aguja and Javelina Formations in BBNP indicate a significant shift from marine to continental deposition. This change in depositional regime, coupled with thickness similarities between equivalent trough and platform rocks, indicate the trough had filled and major subsidence had ended by Late Cretaceous time (Lehman and Busbey, 2007).

\section{Late Cretaceous-Early Tertiary Laramide Orogeny}

The Late Cretaceous to early Tertiary Laramide orogeny (about 70-50 Ma) had significant influence on the tectonic evolution of BBNP; it was one of the most tectonically active times in the park's history. This period of contractional deformation produced major uplifts, basins, and faults and folds that formed from northeast-directed compression related to subduction of the Pacific/Farallon plate beneath the North American continent at the western edge of the continent (fig. 1-6). The plate collision had a major influence on the development of the Laramide fold and thrust belt, which extends from Canada to Mexico; the Chihuahua tectonic belt, south of BBNP, represents the frontal edge of the Laramide fold and thrust belt in the region.

Features of the Laramide orogeny in BBNP (fig. 1-6) include the northeast-facing Mesa de Anguila, an uplifted monocline on the southwest margin of the park, and the southwest-facing Sierra del Carmen-Santiago Mountains, an uplifted and thrust-faulted monocline bounding the east part of the park. The Tornillo Basin developed between these uplifted monoclines (Lehman, 1991; Lehman and Busbey, 2007).

The Mesa de Anguila monocline in BBNP was described by DeCamp (1985) as a northeast-directed monoclinal flexure that formed from northeast-directed compression of the Chihuahua tectonic belt against the Diablo Platform. DeCamp (1985) discussed evidence for left-lateral, strike-slip faults at Mesa de Anguila that accommodated uplift of the monocline during the Laramide. The monocline and strike-slip faults were interpreted as an eastern extension of the much broader Terlingua-Solitario uplift, west of BBNP (Erdlac, 1990). Erdlac reported the age of the uplift at between 68 and $50 \mathrm{Ma}$ and interpreted it as a Laramide push-up block, or transfer zone, which primarily accommodated left-lateral shearing related to northeast-directed Laramide compression.
The Sierra del Carmen-Santiago Mountains monocline is characterized by a southwest-directed flexure containing southwest-directed thrust, or reverse faults (fig. 1-6, Santiago thrust) (Poth, 1979; Cobb, 1980; Cobb and Poth, 1980). The feature represents the southwestern margin of a broader feature known as the Marathon uplift (Muehlberger and Dickerson, 1989; Lehman, 1991) or dome (Ewing, 1991). Dickerson (1980) interpreted the feature as a raised basement ridge that was uplifted along basement-cored faults on the Sierra del Carmen trend, and Lehman and Busbey (2007) noted similarities between the uplift and other basement-cored uplifts in the Rocky Mountain Cordilleran foreland belt. The uplift has also been attributed to left-lateral shearing along the faults at the uplift margin (Cobb and Poth, 1980; Muelberger, 1980; Muehlberger and Dickerson, 1989) and was interpreted as part of a broad transfer zone similar to the Terlingua-Solitario uplift (Erdlac, 1990).

The Tornillo Basin of Lehman (1991) formed between the Mesa de Anguila and Sierra del Carmen-Santiago Mountains monoclines (fig. 1-6). Synorogenic rocks that compose the basin fill are mostly fluvial deposits and include, from base to top, the Javelina, Black Peaks, and Hannold Hill Formations (fig. 1-4). Based on sedimentological and structural data, Lehman (1991) reported that Laramide deformation in the Tornillo Basin began with deposition of sediments of the Javelina Formation (70-65 Ma) and ended after the middle Eocene, with deposition of sediments of the Canoe Formation, about $50 \mathrm{Ma}$ (fig. 1-4). The Canoe Formation overlaps folds as well as thrust and reverse faults in the Hannold Hill, Black Peaks, Javelina, and Aguja Formations (Lehman and Busbey, 2007). Major Laramide folds in the Tornillo Basin of BBNP include the Cow Heaven, Mariscal Mountain, and San Vicente anticlines (fig. 1-6).

\section{Middle Tertiary Volcanism and Plutonism}

Major episodes of volcanism and plutonism occurred in BBNP from about 46 to $28 \mathrm{Ma}$ (Maxwell and others, 1967; Barker and others, 1986; Henry and McDowell, 1986). Volcanism and plutonism resulted from shallow subduction of the Farallon plate on the western margin of the North American continent. As the subducted plate descended, it increased in temperature and melting caused magma to form. The magma rose through the continental crust either to erupt at the surface to form volcanic rocks, or to be injected at depth where it solidified to form plutonic rocks. Volcanoes and volcanic rocks in the Big Bend area formed as part of a continental arc that extends from Mexico into Canada.

The oldest volcanic rocks in BBNP are lavas and tuffs of the Chisos Group (fig. 1-4) (Maxwell and others, 1967; Henry and McDowell, 1986; Henry and Davis, 1996). These rocks include mafic lava flows, silicic ash-fall, and ash-flow tuffs that were erupted between about 46 and $33 \mathrm{Ma}$ from poorly known sources in southwest BBNP and adjacent areas in Mexico (Henry and Davis, 1996). These rocks are south and west of the Pine Canyon caldera complex and extend west and south into Mexico (fig. 1-1). 


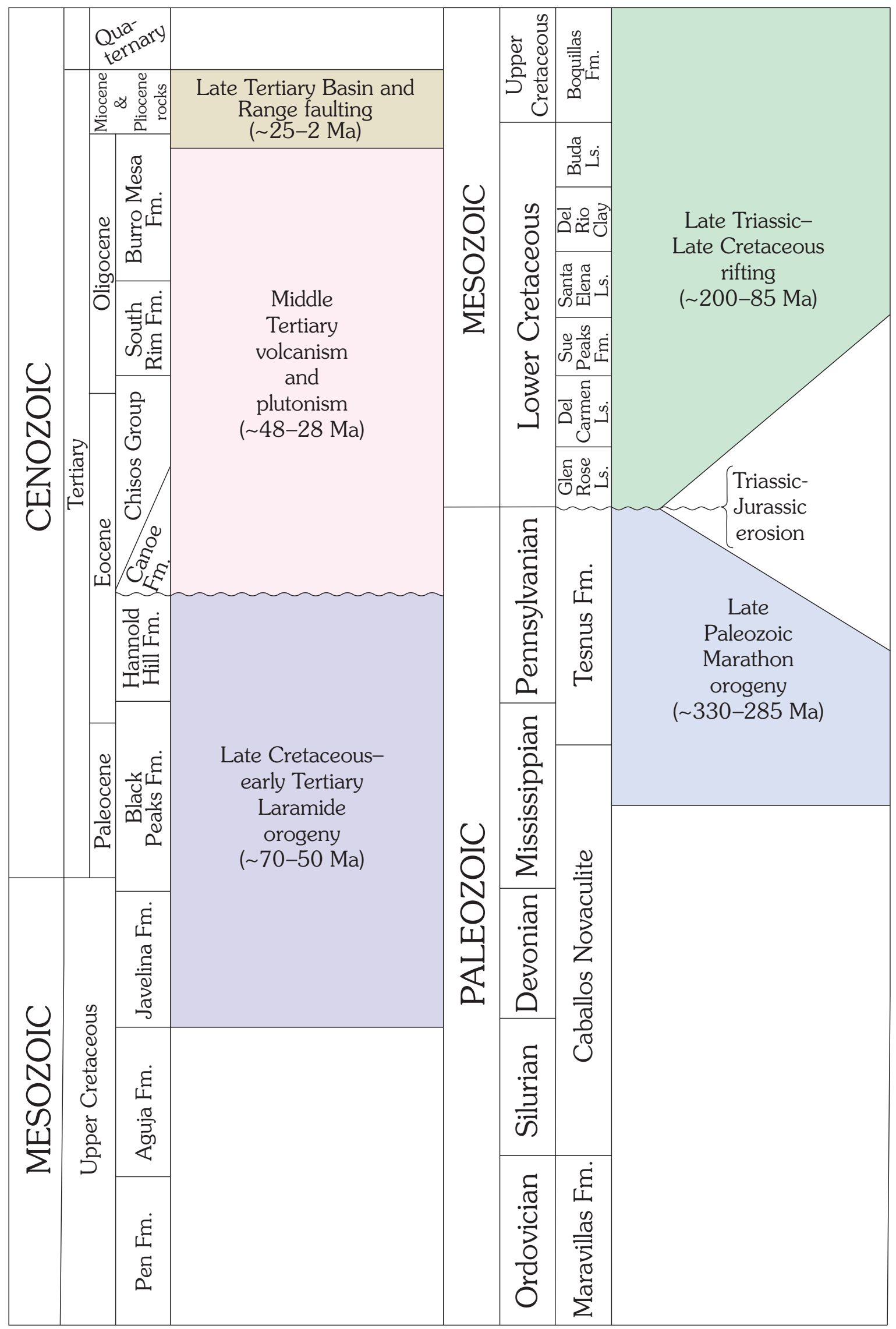

Figure 1-4. Stratigraphic column showing geologic rock units and major tectonic episodes in Big Bend National Park. 


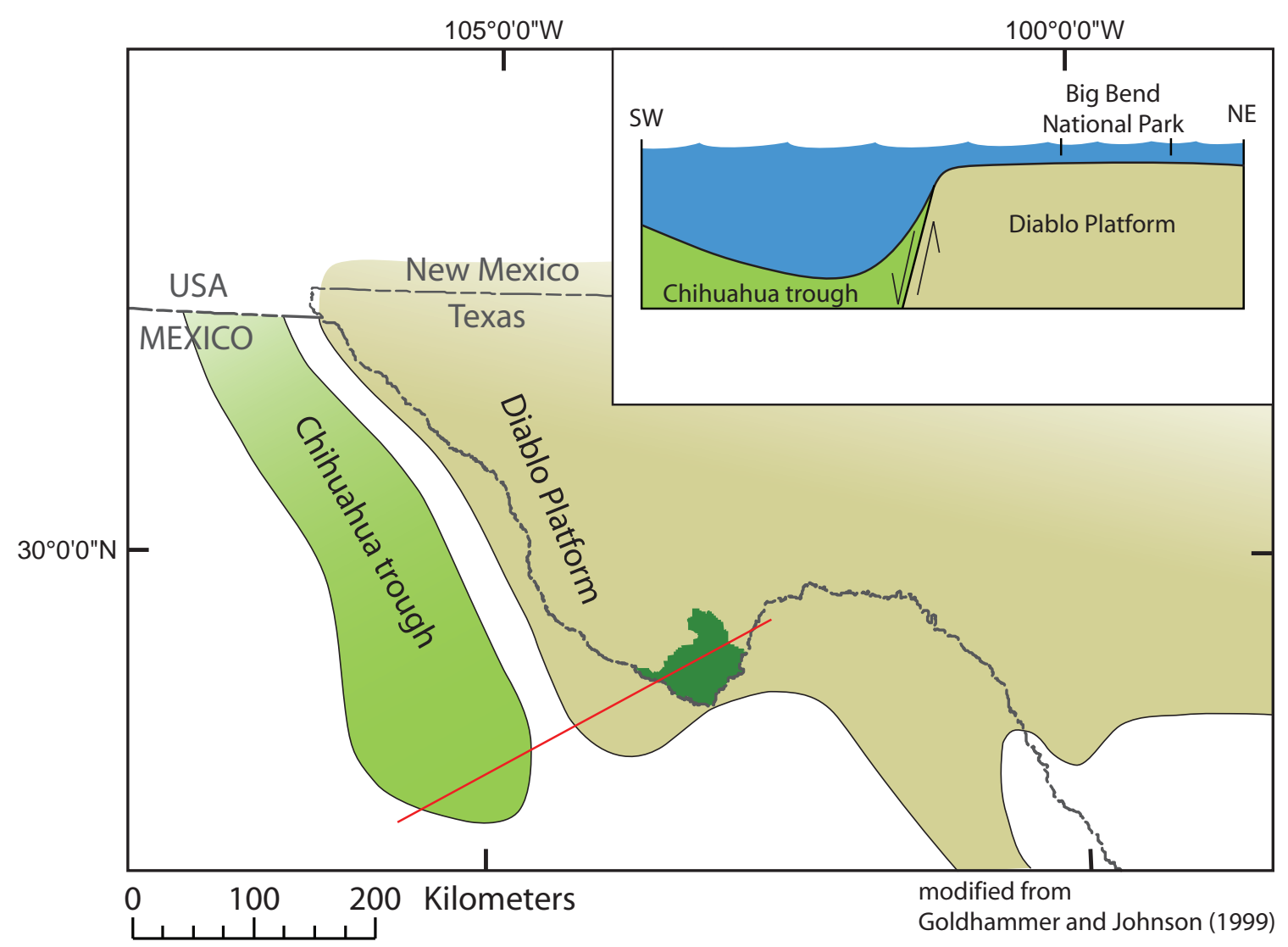

Figure 1-5. Map showing location of the Diablo Platform and the Chihuahua trough, features that formed in the Big Bend area during Late Triassic through Late Cretaceous rifting between North and South America. Solid red line is approximate line of section for inset figure; dark green area is BBNP.

At about $32 \mathrm{Ma}$, the Pine Canyon caldera complex (fig. 1-1) (Ogley, 1978; Barker and others, 1986; Benker, 2005; White and others, 2006) erupted rocks of the South Rim Formation (Barker and others, 1986; Benker, 2005; White and others, 2006). Rocks of the South Rim Formation are mostly preserved in the high Chisos Mountains, particularly the South Rim area (fig. 1-1) where the formation's name originates (Maxwell and others, 1967). The Pine Canyon caldera complex developed originally as a large volcano prior to caldera formation, which elevated the topography throughout the Chisos Mountains (Ogley, 1978; Barker and others, 1986). The massive intrusion surrounding The Basin (Ward MountainPulliam Peak) is likely related to the Pine Canyon caldera magma system, based on similar chemistry (White and others, 2006), and is probably slightly older than the caldera and the South Rim Formation.

Many of the larger intrusive bodies in BBNP were emplaced at about the same time as the Pine Canyon caldera. The laccoliths at the Rosillos Mountains, McKinney Hills, and Grapevine Hills (fig. 1-1) were emplaced between 33 and $32 \mathrm{Ma}$ (Miggins and others, 2007). Although the timing of emplacement for these intrusions is similar to the Pine Canyon caldera, it is unlikely that they are related. However, it is clear there was a significant influx of magma rising into the park at the time of caldera eruption.

At approximately $30 \mathrm{Ma}$, the Sierra Quemada dome (fig. 1-1) formed to the south of The Basin (fig. 1-1). Sierra Quemada has previously been interpreted as a caldera that formed at 33.6 Ma (Duex and Tucker, 1989; Duex, 2007), but recent studies indicate the feature likely formed about 31-30 Ma by doming rather than caldera collapse (Scott and others, 2007). Magma injection caused the existing country rock to dome; the domed rocks were eventually cut by discontinuous ring dikes and smaller sills and dikes, and only a small quantity of extremely lithic-rich material erupted.

The youngest major volcanic and intrusive episode in BBNP is related to the 29.5-Ma Burro Mesa Formation (Miggins and others, 2004; Benker, 2005; White and others, 2006). The Burro Mesa Formation is composed of ash-flow tuffs erupted from small localized vents and lava domes in the southwest part of the park (Holt, 1998; and Parker, 2002). These eruptive rocks are seen as thick capping units above rocks of the Chisos Group at Kit Mountain, Goat Mountain, and Cerro Castellan (Miggins and others, this volume). Volcanism and intrusive events of the Burro Mesa Formation represent the last significant phase of igneous activity in BBNP. 


\section{Late Tertiary Basin and Range Faulting}

The last major tectonic episode in the park was Basin and Range faulting, which occurred in the park from about 25 to $2 \mathrm{Ma}$. Basin and Range normal faulting began at about $25 \mathrm{Ma}$ in Trans-Pecos Texas (Henry, 1998) and resulted from rifting across the Basin and Range Province of western North America. The rifting caused stretching or pulling apart of the western North America crust to form uplifted ranges and intervening down-dropped basins. Big Bend National Park is part of the Rio Grande rift, a subprovince of the Basin and Range Province, which extends northward through New Mexico and into Colorado. Dickerson (1980), Muehlberger (1980), and DeCamp (1985) reported that some Basin and Range faults in the BBNP area of the Rio Grande rift (Mesa de Anguila area) also exhibited a component of right-lateral shear, reflecting northwestward movement of Mexico relative to Texas.

Major Basin and Range faults in BBNP are shown in figure 1-1. Some of these faults formed local depositional basins, such as the Estufa and Dehalo bolsons (Stevens and Stevens, 1989) on the flanks of the high Chisos Mountains (fig. 1-1). The bolsons contain thick accumulations of Miocene-Pliocene sediments that were deposited into half-grabens dipping away from the Chisos Mountains (Stevens and Stevens, 1989; Lehman and Busbey, 2007). The Delaho bolson is characterized by three or four major northwest-striking faults, while the Estufa bolson is bound on its west side by the northwest-striking Dugout Wells fault zone (Stevens and Stevens, 1989).

Other notable Basin and Range faults in BBNP include the Terlingua and Sierra del Carmen fault zones and the Chalk Draw and Burro Mesa faults (fig. 1-1). The Terlingua fault zone forms the steep limestone cliffs on the northeast side of Mesa de Anguila near the mouth of Santa Elena Canyon (DeCamp, 1985; Lehman and Busbey, 2007). The Sierra del Carmen fault zone consists of numerous northwest-striking normal faults that flank the Sierra del Carmen. The Terlingua and Sierra del Carmen fault zones are interpreted to have formed by reactivation of the older Laramide Mesa de Anguila and Sierra del Carmen-Santiago Mountains monoclinal uplifts (Poth, 1979; Cobb, 1980; Cobb and Poth, 1980; DeCamp, 1985). In northern BBNP, the northwest-striking Chalk Draw fault bounds the Chalk Draw graben and was interpreted as a late Paleozoic structure that was reactivated during the Laramide orogeny and again during Basin and Range faulting (Dickerson, 1980; Muehlberger and Dickerson, 1989). The Burro Mesa fault is a down-to-the-southwest normal fault exposed on the northeast flank of Burro Mesa, where it drops rocks of the Chisos Group down against the Aguja Formation (Maxwell and others, 1967). The fault forms the eastern boundary of the Castolon graben as defined by Stevens (1969) and Muehlberger (1989).

Basin and Range faults predated integration of the late Tertiary basins with the Rio Grande, which began about 2 Ma (Henry, 1998), and they were the last structures to shape
BBNP's present-day landscape. The Quaternary Period (1.8 Ma to present) in BBNP was characterized by extensive erosion, down-cutting, and some aggradation related to integration of BBNP basins with the Rio Grande. The Quaternary geology of BBNP is summarized in Berry and Williams (this volume), Berry (2008), and Lehman and Busbey (2007).

\section{Summary}

The oldest tectonic episode recorded in the park is mountain building associated with the Paleozoic Marathon orogeny, which affected the rocks in the park region from Middle Mississippian to Early Permian time (about 330-285 Ma). Only remnants of this oldest episode remain in BBNP's present-day landscape.

From the Late Triassic into the Late Cretaceous (about 200-85 Ma), the BBNP area experienced subtle affects of rifting, or seafloor spreading, between the North and South American continents; this rifting largely controlled the opening of the Gulf of Mexico. During rifting, BBNP was part of the Diablo Platform, a carbonate platform where the sediments that would become Lower and Upper Cretaceous limestone and shale units were deposited in shallow, open-marine water.

The Late Cretaceous to early Tertiary Laramide orogeny (about 70-50 Ma) had significant influence on the tectonic history of BBNP. This period of contractional deformation produced major uplifts, basins, and faults and folds that formed from northeast-directed compression related to collision between the North American continent and the Pacific/ Farallon plate at the western edge of the continent. Major Laramide features in the park include the northeast-facing Mesa de Anguila uplifted monocline on the southwest margin of the park and the southwest-facing Sierra del Carmen-Santiago Mountains uplifted and thrust-faulted monocline bounding the east part of the park. The Tornillo Basin developed between the uplifted basin margins.

Major episodes of volcanism and plutonism occurred in the park area from about 46 to $28 \mathrm{Ma}$. Principal features formed in this time period include numerous volcanic flows extruded from a complex system of volcanic vents and lava domes in the western part of the park and adjacent areas of Mexico, and the Pine Canyon caldera complex in the high Chisos Mountains. Laccolithic complexes developed and intruded Cretaceous and Tertiary sedimentary rocks to form the Rosillos Mountains, McKinney Hills, and Grapevine Hills.

The last major tectonic episode to affect BBNP was Basin and Range faulting from about 25 to $2 \mathrm{Ma}$. Movements on some of the major faults have formed local depositional basins, such as the Estufa and Delaho bolsons on the flanks of the high Chisos Mountains. Basin and Range faults predated integration of the late Tertiary basins with the Rio Grande, which began about $2 \mathrm{Ma}$, and they were the last structures to modify the landscape into its present-day configuration. 


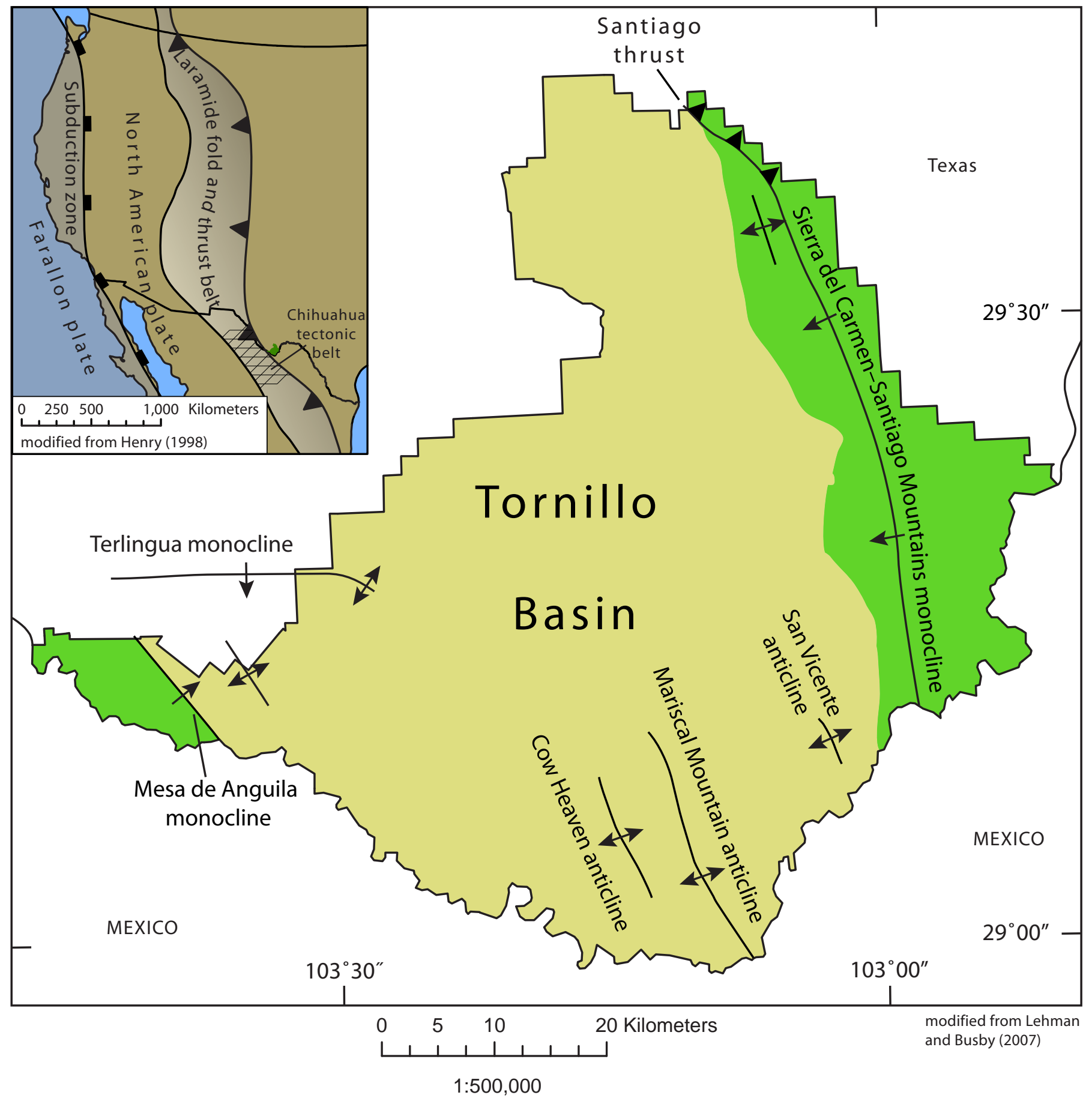

Figure 1-6. Generalized map of the major structures that formed in BBNP during the Laramide orogeny. Inset map shows location of Laramide fold and thrust belt in western North America and Chihuahua tectonic belt in the BBNP area. 


\section{References Cited}

Albritton, D.D., Jr., and Smith, J.F., Jr., 1957, The Texas Lineament: Proceedings of the $20^{\text {th }}$ International Geological Congress, Mexico City, Mexico, p. 508-518.

Barker, D.S., Henry, C.D., and McDowell, F.W., 1986, Pine Canyon caldera, Big Bend National Park-A mildly peralkaline magamatic system, in Price, J.G., Henry, C.D., Parker, D.F., and Barker, D.S., eds., Igneous geology of Trans-Pecos Texas-Field trip guide and research articles: University of Texas at Austin, Bureau of Economic Geology Guidebook 23, p. 266-285.

Benker, S.C., 2005, The petrology of the South Rim Formation, Big Bend National Park, Texas: Richmond, Ky., Eastern Kentucky University, M.S. thesis, 94 p.

Berry, M.E., 2008, Mapping surficial geology in the border region of Big Bend National Park, Texas, in Norman, L.M., Hirsch, D.D., and Ward, A.W., eds., Proceedings of a USGS workshop on facing tomorrow's challenges along the U.S.Mexico border-Monitoring, modeling, and forecasting change within the Arizona-Sonora transboundary watersheds: U.S. Geological Survey Circular 1322, p. 11.

Cobb, R.C., 1980, Structural geology of the Santiago Mountains between Pine Mountains and Persimmon Gap, Trans-Pecos, Texas: Austin, Tex., University of Texas, M.A. thesis, $69 \mathrm{p}$.

Cobb, R.C., and Poth, S., 1980, Superposed deformation in the Santiago and northern Del Carmen Mountains, Trans-Pecos Texas, in Trans-Pecos Region (West Texas): New Mexico Geological Society Fall Field Conference Guidebook 31, p. $71-75$.

DeCamp, D.W., 1985, Structural geology of Mesa de Anguila, Big Bend National Park, in Dickerson, P.W., and Muehlberger, W.R., eds., Structure and tectonics of TransPecos Texas: West Texas Geological Society Publication 85-81, p. 127-135.

Dickerson, P.W., 1980, Structural zones transecting the southern Rio Grande rift-Preliminary observations, in Trans-Pecos Region (West Texas): New Mexico Geological Society Fall Field Conference Guidebook 31, p. 63-70.

Duex, T., 2007, Evidence of caldera activity in the Sierra Quemada, Big Bend National Park, Texas [abs.]: Geological Society of America Abstracts with Programs, v. 39, no. 6, p. 511.

Duex, T.W., and Tucker, D.R., 1989, Geologic history of the Sierra Quemada caldera, Big Bend National Park, Texas [abs.]: Geological Society of America Abstracts with Programs, v. 21, no. 1, p. 9.
Erdlac, Richard J., Jr., 1990, A Laramide-age push-up blockThe structures and formation of the Terilingua-Solitario structural block, Big Bend region, Texas: Geological Society of America Bulletin, v. 102, p. 1,065-1,076.

Ewing, T.E., 1991, The tectonic framework of Texas: University of Texas at Austin, Bureau of Economic Geology Tectonic Map of Texas, 1:750,000 scale.

Goldhammer, R.K., and Johnson, C.A., 1999, Mesozoic sequence stratigraphy and paleogeographic evolution of northeast Mexico, in Bartolini, C., Wilson, J.L., and Lawton, T.F., eds., Mesozoic sedimentary and tectonic history of north-central Mexico: Geological Society of America Special Paper 340, p. 1-58.

Henry, C.D., 1998, Geology of Big Bend Ranch State Park, Texas: University of Texas at Austin, Bureau of Economic Geology Guidebook 27, 72 p.

Henry, C.D., and Davis, L.L, 1996, Tertiary volcanic, volcaniclastic, and intrusive rocks adjacent to the Solitario, in Henry, C.D., and Muehlberger, W.R., eds., Geology of Solitario Dome, Trans-Pecos Texas: University of Texas at Austin, Bureau of Economic Geology Report of Investigations no. 240, p. 85-105.

Henry, C.D., and McDowell, F.W., 1986, Geochronology of magmatism in the Tertiary volcanic field, Trans-Pecos Texas, in Price, J.G., Henry, C.D., Parker, D.F., and Barker, D.S., eds., Igneous geology of Trans-Pecos Texas-Field trip guide and research articles: University of Texas at Austin, Bureau of Economic Geology Guidebook 23, p. 99-122.

Holt, G.S., 1998, Trace element partioning of alkali feldspar in Burro Mesa Rhyolite and other units of the Trans-Pecos Magmatic Province: Waco, Tex., Baylor University, M.S. thesis, $119 \mathrm{p}$.

Lehman, T.M., 1991, Sedimentation and tectonism in the Laramide Tornillo basin of West Texas: Sedimentary Geology, v. 75, p. 9-28.

Lehman, T.M., and Busbey, A.B., 2007, Society of Vertebrate Paleontology Fall 2007 Big Bend field trip guide: Austin, Tex., Society of Vertebrate Paleontology, 117 p.

Maxwell, R.A., Lonsdale, J.T., Hazzard, R.T., and Wilson, J.A., 1967, Geology of Big Bend National Park, Brewster County, Texas: University of Texas at Austin, Bureau of Economic Geologic Publication no. 6711, 320 p.

McBride, E.F., 1989, Stratigraphy and sedimentary history of pre-Permian Paleozoic rocks in the Marathon uplift, in Hatcher, R.D., Jr., Thomas, W.A., and Viele, G.W., eds., The Appalachian-Ouachita orogen in the United States. The Geology of North America, v. F2, chapter 20: Geological Society of America, p. 603-620. 
Miggins, D., Anthony, E., Ren, M., and Wache, K., 2007, New ${ }^{40} \mathrm{Ar} /{ }^{39} \mathrm{Ar}$ ages, geochemistry, and stratigraphy for mafic and rhyolitic volcanic units from Big Bend National Park, Texas [abs.]: Geological Society of America Abstracts with Programs, v. 39, no, 6, p. 635.

Miggins, D., Scott, R.B., and Snee, L.W., 2004, New ${ }^{40} \mathrm{Ar} /{ }^{39} \mathrm{Ar}$ ages from Big Bend National Park [abs.]: Geological Society of America Abstracts with Programs, v. 36, no. 5, p. 128.

Muehlberger, W.R., 1980, Texas lineament revisited, in TransPecos Region (West Texas): New Mexico Geological Society Fall Field Conference Guidebook 31, p. 113-121.

Muehlberger, W.R., 1989, Summary of the structural geology of Big Bend National Park and vicinity, in Muehlberger, W.R., and Dickerson, P.W., leaders, $28^{\text {th }}$ International Geological Congress fieldtrip guidebook T317: American Geophysical Union, p. 179-197.

Muehlberger, W.R., and Dickerson, P.W., 1989, A tectonic history of Trans-Pecos Texas, in Muehlberger, W.R., and Dickerson, P.W., leaders, $28^{\text {th }}$ International Geological Congress fieldtrip guidebook T317: American Geophysical Union, p. 35-54.

Muehlberger, W.R., and Tauvers, P.R., 1989, Marathon fold-thrust belt, west Texas, in Hatcher, R.D. Jr., Thomas, W.A., and Viele, G.W., eds., The Appalachian-Ouachita orogen in the United States. The Geology of North America, v. F2, chapter 24: Geological Society of America, p. 673-680.

Noble, P.J., 1994, Silurian radiolarian zonation for the Caballos Novaculite, Marathon uplift, west Texas: Bulletin of American Paleontology, v. 106, no. 345, 55p.

Ogley, D.S., 1978, Eruptive history of the Pine Canyon Caldera, Big Bend National Park, Texas: Austin, Tex., University of Texas, M.S. thesis, 68 p.

Page, W.R., and Harris, A.G., 2007, Late Ordovician conodonts from the Maravillas Formation near Persimmon Gap, Big Bend National Park, Texas [abs.]: Geological Society of America Abstracts with Programs, v. 39, no. 6, p. 635.
Parker, D.F., 2002, Horseshoe Canyon volcanic dome, in White, J.C., ed., What we have learned since Maxwell and others (1967)?: Geological Society of America South-Central Meeting, Alpine, Tex., Field trip guide, p. 24-32.

Poole, F.G., Perry, W.J., Jr., Madrid, R.J., and AmayaMartinez, R., 2005, Tectonic synthesis of the OuachitaMarathon-Sonora orogenic margin of southern LaurentiaStratigraphic and structural implications for timing of deformational events and plate tectonic model, in Anderson, T.H., Nourse, J.A., McKee, J.W., and Steiner, M.B., eds., The Mojave-Sonora megashear hypothesis-Development, assessment, and alternatives: Geological Society of America Special Paper 393, p. 543-596.

Poth, S., 1979, Structural transition between the Santiago and Del Carmen Mountains in northern Big Bend National Park, Texas: Austin, Tex., University of Texas, M.A. thesis, 55 p.

Scott, R.B., Turner, K.J., Budahn, J., and Miggins, D., 2007, Sierra Quemada-A failed caldera, Big Bend National Park [abs.]: Geological Society of America Abstracts with Programs, v. 39, no. 6, p. 512.

Stevens, J.B., 1969, Geology of the Castolon area, Big Bend National Park, Brewster County, Texas: Austin, Tex., University of Texas, Ph.D. dissertation, 129 p.

Stevens, J.B., and Stevens, M.S., 1989, Stratigraphy and major structural-tectonic events along and near the Rio Grande, Trans-Pecos Texas and adjacent Chihuahua and Coahuila, Mexico, in Dickerson, P.W., Stevens, M.S., and Stevens, J.B., eds., Geology of Big Bend and Trans-Pecos Texas: South Texas Geological Society, p. 73-116

Thomas, W.A., 1991, The Appalachian-Ouachita rifted margin of southeastern North America: Geological Society of America Bulletin, v. 103, no. 3, p. 415-431.

White, J.C., Benker, S.C., Ren, M., Urbanczyk, K., and Corrick, D.W., 2006, Petrogenesis and tectonic setting of the peralkaline Pine Canyon caldera, Trans-Pecos Texas: Lithos, v. 91, p. 74-94.

Wilson, J.L., 1954, Ordovician Stratigraphy in the Marathon folded belt: American Association of Petroleum Geologists, v. 38 , p. $2,455-2,475$. 



\title{
2. Surficial Deposits of Big Bend National Park
}

\author{
By Margaret E. Berry and Van S. Williams
}

\section{Abstract}

The Quaternary geologic and climatic history of Big Bend National Park is recorded in multiple levels of pedimentcapping gravel deposits, stream and river alluvium, and alluvial-fan deposits that cover much of the park. Based on relative-age indicators (soil development and surface morphology) on these surfaces, the oldest ones probably are middle (or possibly early) Pleistocene, the intermediate ones middle and late Pleistocene, and the youngest ones late Pleistocene to Holocene and Holocene in age. Eolian landforms in this arid region are relatively minor in extent. Alluvial valley floors have been deflated locally by wind erosion and in places are covered by small coppice dunes, but large areas of eolian sand deposition are generally lacking. In the northernmost part of the park, patterns that resemble eolian deposits on aerial photographs are formed by bands of relatively dense vegetation separated by more sparsely vegetated interband areas. This type of banded vegetation develops in desert environments like that of Big Bend National Park to maximize water available for plant growth.

\section{Introduction}

Surficial deposits in Big Bend National Park, west Texas, record the long and complex Quaternary geologic and climatic history of this border region. Since the Rio Grande became established, probably in late Pliocene to early Pleistocene time (fig. 2-1, table 2-1) (Dickerson and Muehlberger, 1994), the fluvial system has been dominated by long-term incision (the downward erosion of a stream, deepening the stream channel by removal of rock and sediment) punctuated by episodes of aggradation (the building-up of a stream valley by deposition of sediment) that were likely related to fluctuations in climate (Dethier, 2001; Connell and others, 2005). The Big Bend area was far removed from alpine glaciations that occurred during the Pleistocene in the mountainous headwaters of the Rio Grande, located in northern New Mexico and southern Colorado (Connell and others, 2005). Data from fossil packrat middens (the piles of plant and animal remains collected by packrats and preserved by crystallized packrat urine) found in and around Big Bend National Park indicate that during the last major glaciation (around 20,000 years ago) Big Bend's climate was characterized by milder winters, cooler summers, and more precipitation than in postglacial times; they also show that conifer woodlands extended from the mountains out onto the lowlands (Elias, 1997). Since the transition to a postglacial environment 10,000-11,000 years ago, the climate in the Big Bend area has become hotter and drier with less effective moisture, and for the last 4,200 years or more the lowlands have supported desert vegetation similar to that found in the region today (Elias, 1997).

\section{Quaternary Alluvial Deposits}

Thin gravel deposits capping pediments (broad, gentlysloping, laterally-planed erosion surfaces), alluvial-fan deposits, and stream or river alluvium cover a large part of the park. Material suitable for radiocarbon dating of the deposits is scarce, and volcanic ashes, useful in constraining ages of Quaternary surficial deposits elsewhere in the western and southwestern United States, have not been found as far south as Big Bend. Therefore, relative-age criteria are used to interpret age relationships of the geomorphic surfaces of the deposits (for example, Bull, 1991). Criteria used to assess relative age include relative height above the valley floor, which is higher for older surfaces where streams have incised; preservation state of depositional morphology, which is subdued through time by post-depositional processes; and amount of surface dissection, characteristics of desert pavement, soil development, and weathering, all of which tend to increase or change predictably through time.

The surficial deposits are grouped based on their genesis and relative age (table 2-2). Groups Qya, Qyw, Qia, and Qiw can be further subdivided by relative age in many places in the park. River deposits are differentiated from other types of alluvium mainly along the Rio Grande, where morphological distinctions are pronounced. Terraces along this portion of the Rio Grande typically are underlain by coarse-gravel deposits with subrounded to well-rounded clasts. Soil carbonate accumulation on the terraces tends to be somewhat greater than that in corresponding fan and pediment alluvium, likely due to subtle textural differences that may influence percolation through the soil. 


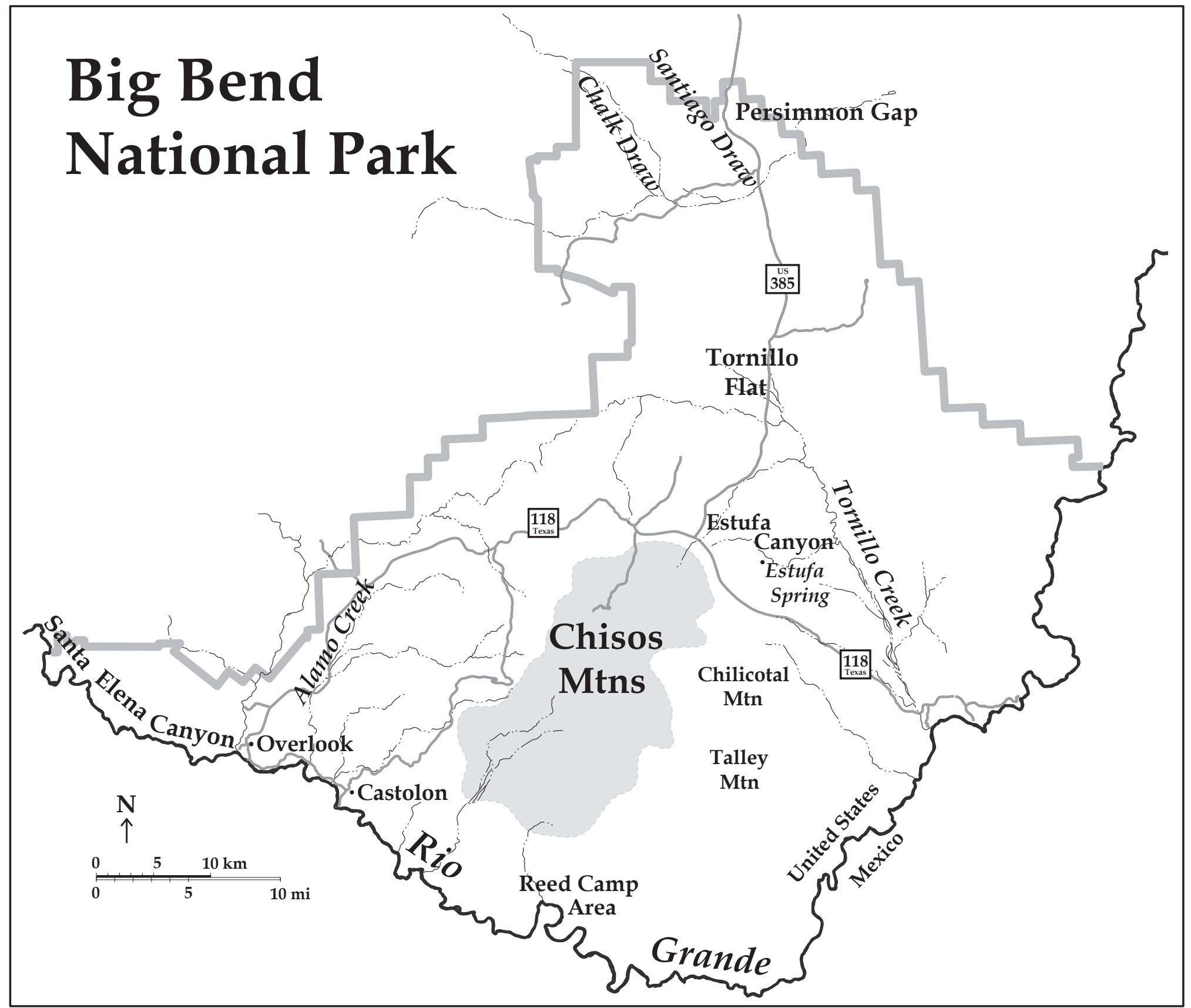

Figure 2-1. Map showing locations within Big Bend National Park that are referred to in the text. 
Table 2-1. Age estimates for time divisions within the Tertiary and Quaternary Periods. Based on USGS “Divisions of Geologic Time" (U.S. Geological Survey Geologic Names Committee, 2007) and the ICS time scale (0gg, 2004).

\begin{tabular}{|c|c|c|c|}
\hline $\begin{array}{c}\text { Geologic time } \\
\text { period }\end{array}$ & \multicolumn{2}{|c|}{ Time divisions } & Age estimate \\
\hline \multirow{4}{*}{ 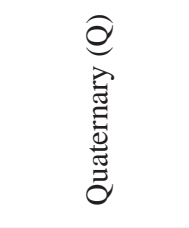 } & \multicolumn{2}{|l|}{ Holocene } & $11,500-0 \mathrm{yr}$ \\
\hline & \multirow{3}{*}{ Pleistocene } & late & $126,000-11,500 \mathrm{yr}$ \\
\hline & & middle & $781,000-126,000 \mathrm{yr}$ \\
\hline & & early & $1.8 \mathrm{Ma}-781,000 \mathrm{yr}$ \\
\hline \multirow{5}{*}{ 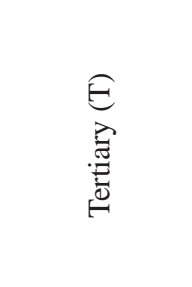 } & \multicolumn{2}{|l|}{ Pliocene } & $5.3-1.8 \mathrm{Ma}$ \\
\hline & \multicolumn{2}{|l|}{ Miocene } & $23-5.3 \mathrm{Ma}$ \\
\hline & \multicolumn{2}{|l|}{ Oligocene } & $33.9-23 \mathrm{Ma}$ \\
\hline & \multicolumn{2}{|l|}{ Eocene } & $55.8-33.9 \mathrm{Ma}$ \\
\hline & \multicolumn{2}{|l|}{ Paleocene } & $65.5-55.8 \mathrm{Ma}$ \\
\hline
\end{tabular}

Table 2-2. Surficial deposits in Big Bend National Park.

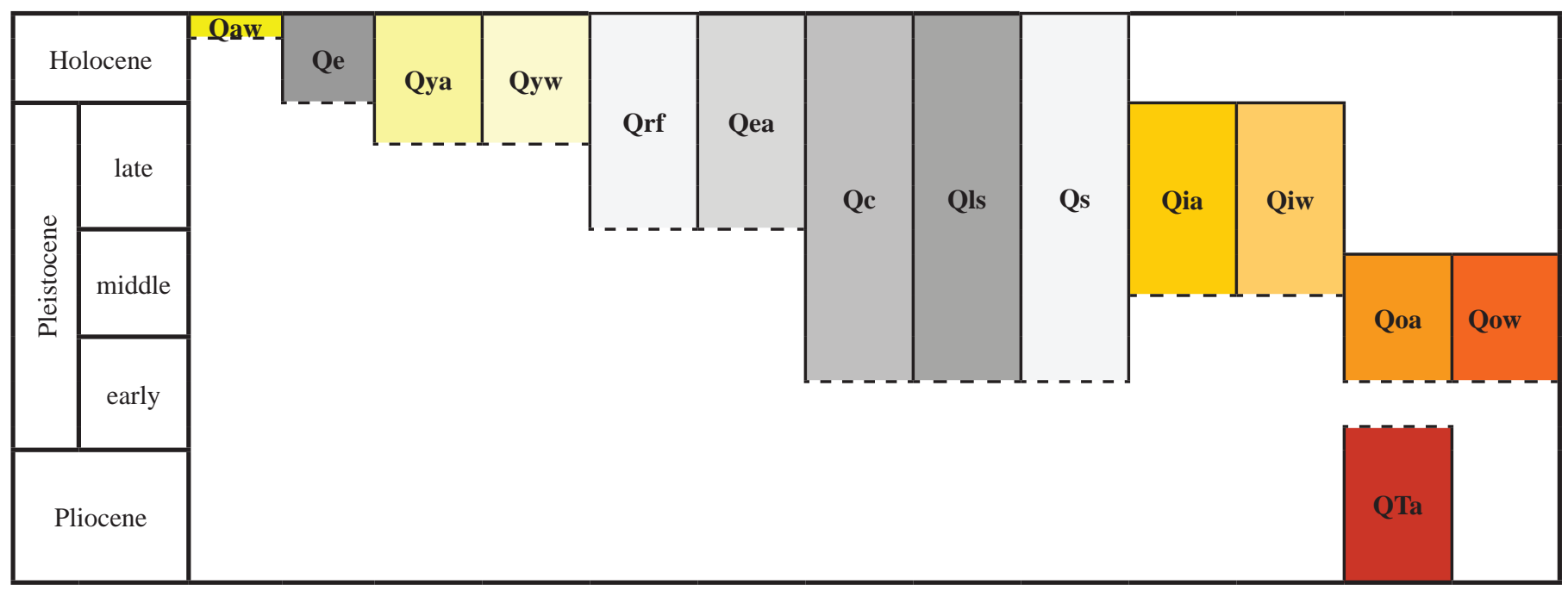

Definition of unit symbols and estimated relative age ranges:

Qaw: Active tributary wash and river deposits; latest Holocene

Qe: $\quad$ Eolian sand; Holocene

Qya: Young alluvial deposits (pediment, fan, and stream), undivided; Holocene to late Pleistocene

Qyw: Young axial river deposits; Holocene to late Pleistocene

Qrf: $\quad$ Rock-fall deposits; Holocene and late Pleistocene

Qea: $\quad$ Mixed eolian and alluvial deposits; Holocene and late Pleistocene

Qc: $\quad$ Slope deposits consisting of colluvial aprons and colluvial-fan deposits; Holocene to early? Pleistocene

Qls: $\quad$ Landslide deposits; Holocene to early? Pleistocene

Qs: $\quad$ Spring deposits; Holocene to early? Pleistocene

Qia: Intermediate alluvial deposits (pediment, fan, and stream), undivided; late and middle Pleistocene

Qiw: Intermediate axial river deposits; late and middle Pleistocene

Qoa: Old alluvial deposits (pediment, fan, and stream), undivided; middle to early? Pleistocene

Qow: Old axial river deposits; middle to early? Pleistocene

QTa: Very old alluvium; early Pleistocene and Pliocene 


\section{Bolson Fill}

General characteristics of the young alluvial deposits (Qya and Qyw, Holocene to late Pleistocene) include limited preservation of original surface morphology (channel topography and bar-and-swale or meander-scroll topography) and low relative height above active stream channels or valley floors. Deposits are generally unconsolidated to weakly consolidated. Development of desert pavement, varnish, and soil carbonate range from little or none on the younger of the Qya and $\mathbf{Q y w}$ deposits to densely packed and uniform pavement with well-varnished clasts and stage $\mathrm{I}^{1}$ soil-carbonate morphology on the older of the Qya and Qyw deposits. For further discussion of soil-carbonate morphology and the formation of soils in arid environments, see Birkeland (1999).

Intermediate-age alluvial deposits (Qia and Qiw, late and middle Pleistocene), at intermediate relative height, typically have surfaces that are uniform (due to the obliteration of original, depositional morphology), partly incised, and slightly rounded at the edges. Deposits are generally weakly to moderately well consolidated. Pavement ranges from weakly developed to densely packed and uniform with well-varnished clasts. Soils typically have stage I-II (locally weakly cemented stage III) carbonate morphology on the younger of the Qia and Qiw deposits and weakly to moderately cemented stage III-IV carbonate morphology on the older of the Qia and Qiw deposits.

Old alluvial deposits (Qoa and Qow, middle to early? Pleistocene), at high relative height, are commonly moderately to well consolidated. Surfaces have been dissected into ridge and ravine (ballena) topography where gravel deposits are relatively thick (as in the fan deposits), or are preserved as generally planar or gently undulatory remnants high above adjacent valley floors where gravel deposits are thin (as on the pediments). Surface pavements range from weakly developed to moderately packed and uniform with moderately varnished clasts; soils typically have weakly to moderately cemented stage IV carbonate morphology.

Very old alluvium (QTa, early Pleistocene and Pliocene), typically well consolidated, thick deposits primarily of alluvial fan origin, are eroded and deeply dissected into ridge and ravine (ballena) topography. Near faults, beds have been titled by drag (the folding of beds on either side of a fault due to shear created by movement on the fault). Where preserved, soils have stage III to IV carbonate morphology in horizons as much as $2 \mathrm{~m}$ thick.

\footnotetext{
${ }^{1}$ In gravelly deposits, the progressive development of soil-carbonate morphology is described briefly as follows: Stage I-thin, discontinuous coatings of $\mathrm{CaCO}_{3}$ are present on the bottom side of clasts. Stage $\mathrm{II}-\mathrm{CaCO}_{3}$ coatings are continuous around clasts; the soil matrix is mostly loose, but several clasts may be cemented together locally. Stage III $-\mathrm{CaCO}_{3}$ is disseminated throughout the soil matrix, cementing the horizon and giving it a whitish color. Stage IV-thin laminar layers of almost pure $\mathrm{CaCO}_{3}$ are present in the upper part of the horizon; the rest of the horizon is plugged with accumulated $\mathrm{CaCO}_{3}$.
}

Thick accumulations of Tertiary- and early Quaternaryage sediment, interpreted as bolson fill, ${ }^{2}$ are preserved in several places in the park (Stevens and Stevens, 1989, 1990; Dickerson and Muehlberger, 1994). On the previous map of the park (Maxwell and others, 1967), the bolson fill was combined with Pleistocene pediment, fan, and terrace deposits and referred to as QTog. Fossils found in the deposits indicate that much of the bolson fill is Miocene in age-for example, the Delaho Formation in the Castolon area (Stevens and others, 1969; Stevens, 1977) and the informal Banta Shut-in formation in the lower Tornillo Creek area (Stevens and Stevens, 1989, 2003). In the Estufa bolson, northeast of the Chisos Mountains in the lower Tornillo Creek area (fig. $2-1$ ), an upper Miocene section of sediment is overlain by very old, fault-bounded alluvial-fan deposits (QTa) containing clasts thought to be derived from the Chisos Mountains (informal Estufa member of Thurwachter, 1984, and informal Estufa Canyon formation of Stevens and Stevens, 1989, 2003). The age of these alluvial-fan deposits is unknown, but has been interpreted as Pliocene-Pleistocene (Stevens and Stevens, 1989, 2003), and possibly correlative with very old alluvialfan deposits in the Burro Mesa area (informal Fingers formation of Stevens, 1969, 1988; Stevens and Stevens, 1989).

\section{Landscape Development}

Long-term aggradation represented by the thick bolson fills was followed by degradation that resulted in the erosion of large volumes of rock and sediment from the Big Bend landscape during the Quaternary period; this shift from aggradation to degradation was likely associated with establishment of the Rio Grande and declining rates of fault activity. The Estufa bolson provides a striking example of the amount of erosion that has occurred. The inferred Pliocene-Pleistocene alluvial-fan sediments of the Estufa bolson (QTa) were deposited in a graben (fault-bounded basin), but now stand in high relief, 46 to 73 $\mathrm{m}$ above younger Quaternary sediments subsequently deposited on the upthrown side of the fault (fig. 2-2) (Thurwachter, 1984). The oldest alluvial deposits that postdate erosion of Pliocene-Pleistocene sediments and bedrock from the upthrown side of the fault have strong calcic soils with cemented stage IV horizons $1 \mathrm{~m}$ thick or more (Qoa; fig. 2-3). This degree of soil development likely took several hundred thousand years to form (Machette, 1985) and indicates that the following sequence of events-(1) erosion producing the inverted topography of Estufa bolson, followed by (2) deposition of Qoa gravels, and (3) stabilization of the Qoa surface that allowed a soil to start

\footnotetext{
${ }^{2}$ The term bolson, a Spanish word for large purse, is used in desert regions of the southwestern United States for a broad, mostly internally drained, interior basin (Neuendorf and others, 2005) commonly formed by faulting. Sediment deposited in these closed or semi-closed basins is referred to as bolson fill.
} 


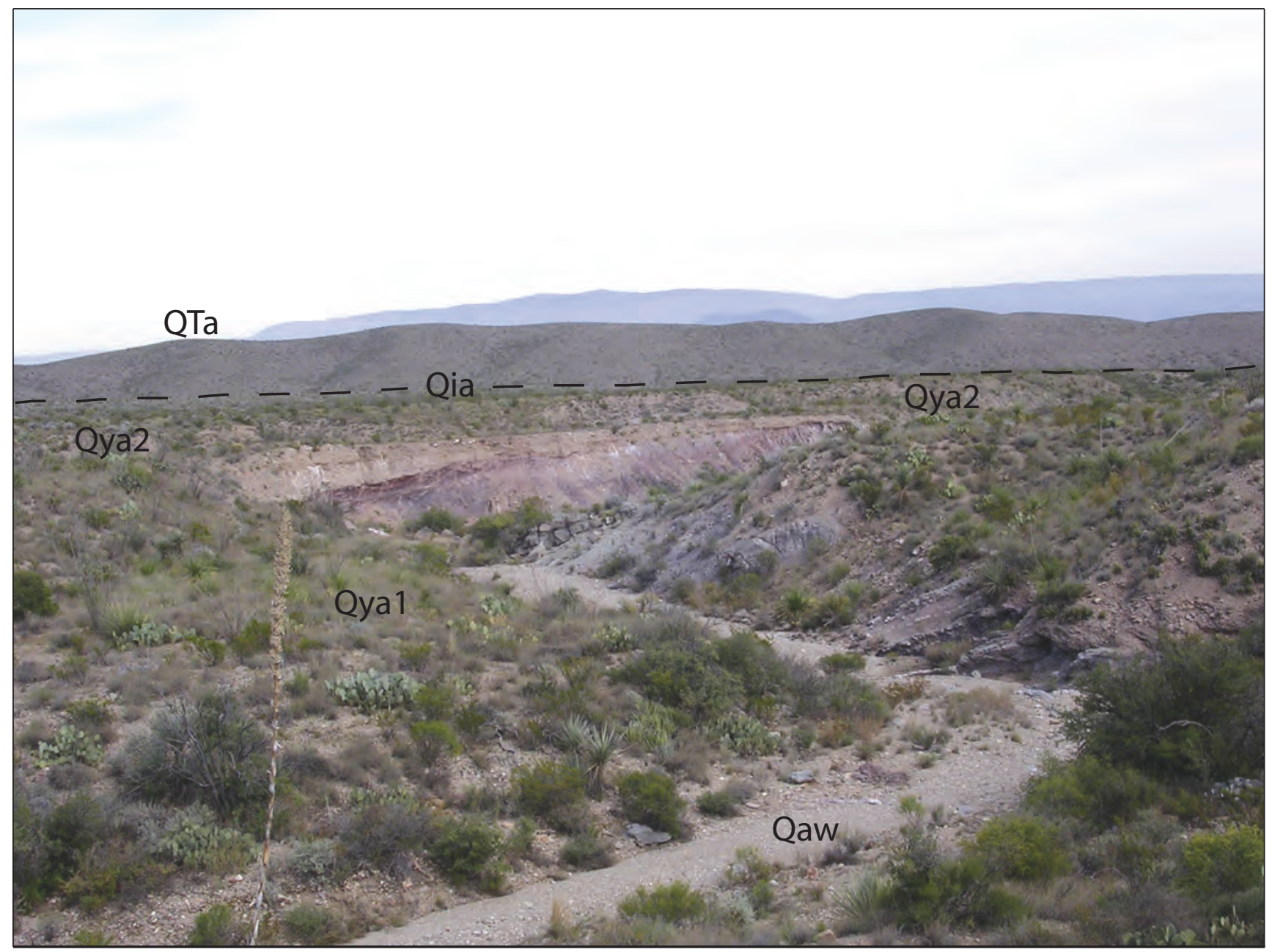

Figure 2-2. Photograph taken near Estufa Spring, looking east (downstream) towards the boundary fault (approximate location shown by dashed line) and sediments of Estufa bolson. Labels mark surfaces of deposits: OTa, inferred Pliocene-Pleistocene alluvial-fan sediments of Estufa bolson, originally deposited in a graben but now standing in high relief above younger Quaternary deposits; Oia, intermediate-age alluvial deposits; Oya2, older of the young alluvial deposits; 0ya1, younger of the young alluvial deposits; 0aw, alluvium deposited in the active tributary wash. Nearby Ooa alluvial deposits are just out of view to the south (right) and north (left). 


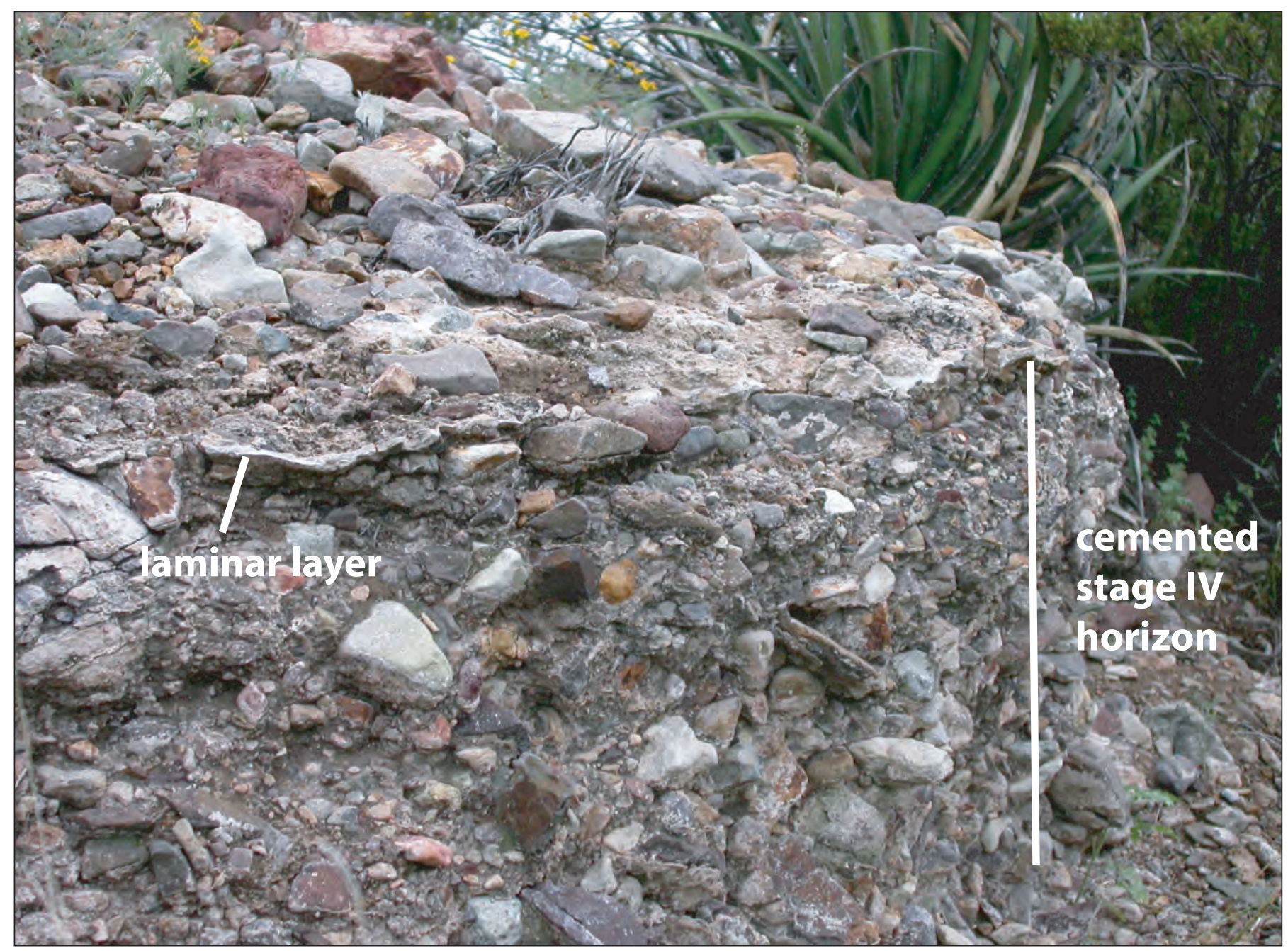

Figure 2-3. Example of the strong calcic soil typical of Qoa deposits in Big Bend National Park. The cemented stage IV horizon (with laminar layers at the top) likely took several hundred thousand years to form (Machette, 1985), suggesting that the 0oa deposits are middle Pleistocene or older. For scale, the larger clasts visible in the photograph are 10 to $15 \mathrm{~cm}$ in diameter. 
forming - was probably complete by several hundred thousand years ago, if not earlier. Given the amount of erosion required in an environment where rates of erosion were probably relatively low, it is likely that the onset of long-term degradation occurred sometime prior to the middle Pleistocene (in the early Pleistocene or late Pliocene).

That extensive erosion of the landscape continued during the middle and late Pleistocene as well is shown by the multiple levels of gravel-capped pediments that are prominent throughout the park (fig. 2-4). Surfaces that make up the highest and therefore oldest relative-age group (Qoa) are thought to be middle to early? Pleistocene, based on the presence of strong calcic soils (cemented stage IV horizons) developed in the gravel deposits capping the pediment surfaces. These old pediment surfaces are typically 30-50 m above the valley floor. Below the highest level are more extensively preserved, intermediate pediment surfaces (Qia2 and Qia1, generally 12-40 $\mathrm{m}$ and 6-24 $\mathrm{m}$ above the valley floor, respectively) that probably formed during the middle and late Pleistocene, based on their relative age characteristics. Still younger pediment surfaces (Qya2), generally $3 \mathrm{~m}$ or more above the valley floor, are probably late Pleistocene to Holocene in age. This extensive erosion of the Big Bend landscape during the Quaternary probably contributed to the destabilization of bedrock slopes, which resulted in large, multi-event landslides in several areas of the park, such as those at the Chilicotal and Talley Mountains (Collins and others, 2007) and the northwest mountain-front of the Chisos.

\section{Rio Grande Terraces}

Multiple levels of coarse-gravel terrace deposits are preserved along the Rio Grande in Big Bend National Park. The fluvial deposits range in thickness from less than $1 \mathrm{~m}$ to over $15 \mathrm{~m}$, but commonly they are at least 3-4 m thick and overlie bedrock. These fluvial deposits probably reflect times during the Quaternary when, in response to periodic changes in climate and river hydrology, long-term incision of the river system was disrupted by episodes of aggradation (Dethier, 2001; Connell and others, 2005).

The highest level (Qow), represented by a few small isolated remnant deposits, is about 55-60 $\mathrm{m}$ above the Rio Grande floodplain (table 2-3, fig. 2-5). The relative age of Qow is equivocal, but based on its height above the next lower level (Qiw3) and the strength of calcic soils found in places on that lower level (moderately cemented stage III to IV horizons), Qow is likely middle Pleistocene or older. Three intermediate levels of terraces (Qiw3, Qiw2, and Qiw1; table 2-3), perhaps best observed in the area between Santa Elena Canyon Overlook and Castolon (figs. 2-1 and 2-5), are probably middle and late Pleistocene in age. Whereas remnants of Qiw3 and Qiw2 are fairly local in their extent, Qiw1 forms broad, flat remnant surfaces that can be traced all along the stretch of river that flows through the park. The lowest terraces along the river (table 2-3) are likely late Pleistocene to Holocene (Qyw2) and Holocene (Qyw1) in age.

\section{Eolian Landforms}

Eolian landforms in this arid region are relatively minor in extent. In areas such as Tornillo Flat, alluvial valley floors have been deflated locally by wind erosion and in places are covered by small coppice dunes (also referred to as nabkhas, dunes formed when wind-blown sand accumulates around and on the lee side of shrubs or vegetation clumps), but large areas of eolian sand deposition are generally lacking. Patterns seen on aerial photographs of the northernmost part of the park, particularly near Chalk Draw, Santiago Draw, and northern Tornillo Flat, resemble eolian features but are actually banded vegetation (figs. 2-1 and 2-6). Best seen in aerial view, banded vegetation, also known as tiger bush or banded mosaic, is made up of bands of relatively dense vegetation separated by more sparsely vegetated interband areas (Aguiar and Sala, 1999; Wakelin-King, 1999; Saco and others, 2006). The banded pattern develops in arid and semiarid environments where water available for plant growth is limited. The bands align perpendicular to slope and form where surface gradients are low such that runoff remains unchanneled. During rainfall events, sheet flow generated in the sparsely vegetated interband areas flows downslope into the dense vegetation bands where it is trapped and infiltrates into the soil. This process maximizes the amount of water available for plant growth in an environment with limited rainfall (Aguiar and Sala, 1999; Wakelin-King, 1999; Saco and others, 2006). Interband areas in Big Bend commonly have a moderately to well-developed pavement or surface crusts that help promote sheet flow (fig. 2-6B, $C$ ).

Table 2-3. Rio Grande terraces and their general correlation to other alluvial deposits in the park.

\begin{tabular}{|c|c|c|}
\hline $\begin{array}{c}\text { Terrace } \\
\text { height }(\mathbf{m})^{1}\end{array}$ & Terrace & Correlation ${ }^{2}$ \\
\hline$\leq 3$ & Qyw1 & Qya1 \\
\hline $4-9$ & Qyw2 & Qya2 \\
\hline $12-18$ & Qiw1 & Qia1 \\
\hline $18-25$ & Qiw2 & \\
\hline $30-45$ & Qiw3 & Qia2 \\
\hline $55-60$ & Qow & Qoa? \\
\hline
\end{tabular}

\footnotetext{
${ }^{1}$ General height above Rio Grande floodplain.

${ }^{2}$ Based on field relations and relative-age data.
} 

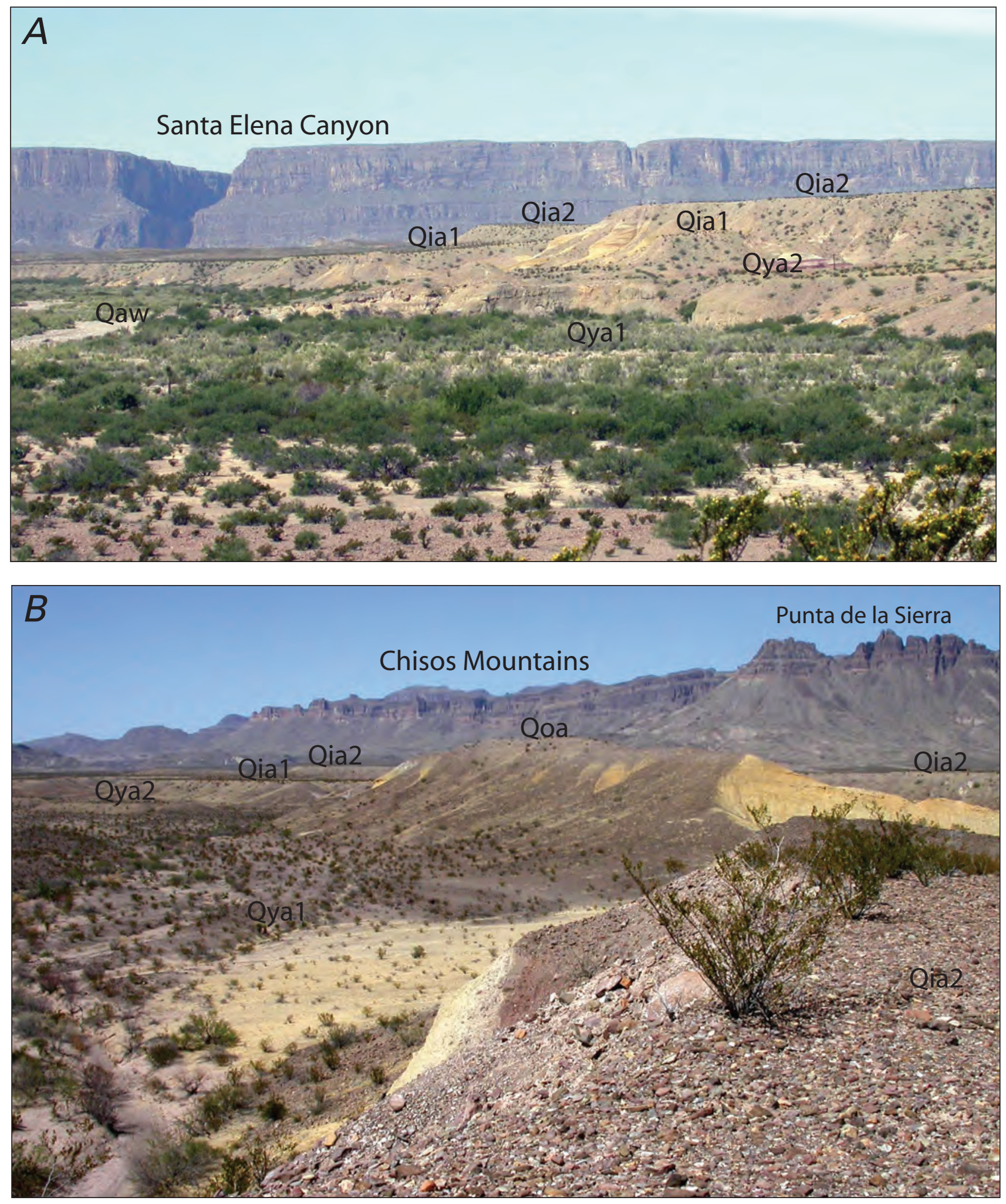

Figure 2-4. Examples of pediment sequences in Big Bend National Park. Labels mark surfaces of thin, gravel-rich, Quaternaryage alluvial deposits that cap Cretaceous-age bedrock made up of yellowish-brown sandstone and yellowish-brown and maroon clay: Qoa, old alluvial deposits; Qia2, older of the intermediate-age alluvial deposits; 0ia1, younger of the intermediate-age alluvial deposits; 0ya2, older of the young alluvial deposits; 0ya1, younger of the young alluvial deposits; 0aw, alluvium deposited in the active tributary wash. $A$, View looking southwest across Alamo Creek towards Santa Elena Canyon, a deep gorge cut by the Rio Grande through Cretaceous-age limestone. B, View looking north (towards the Chisos Mountains) in the Reed Camp area. 


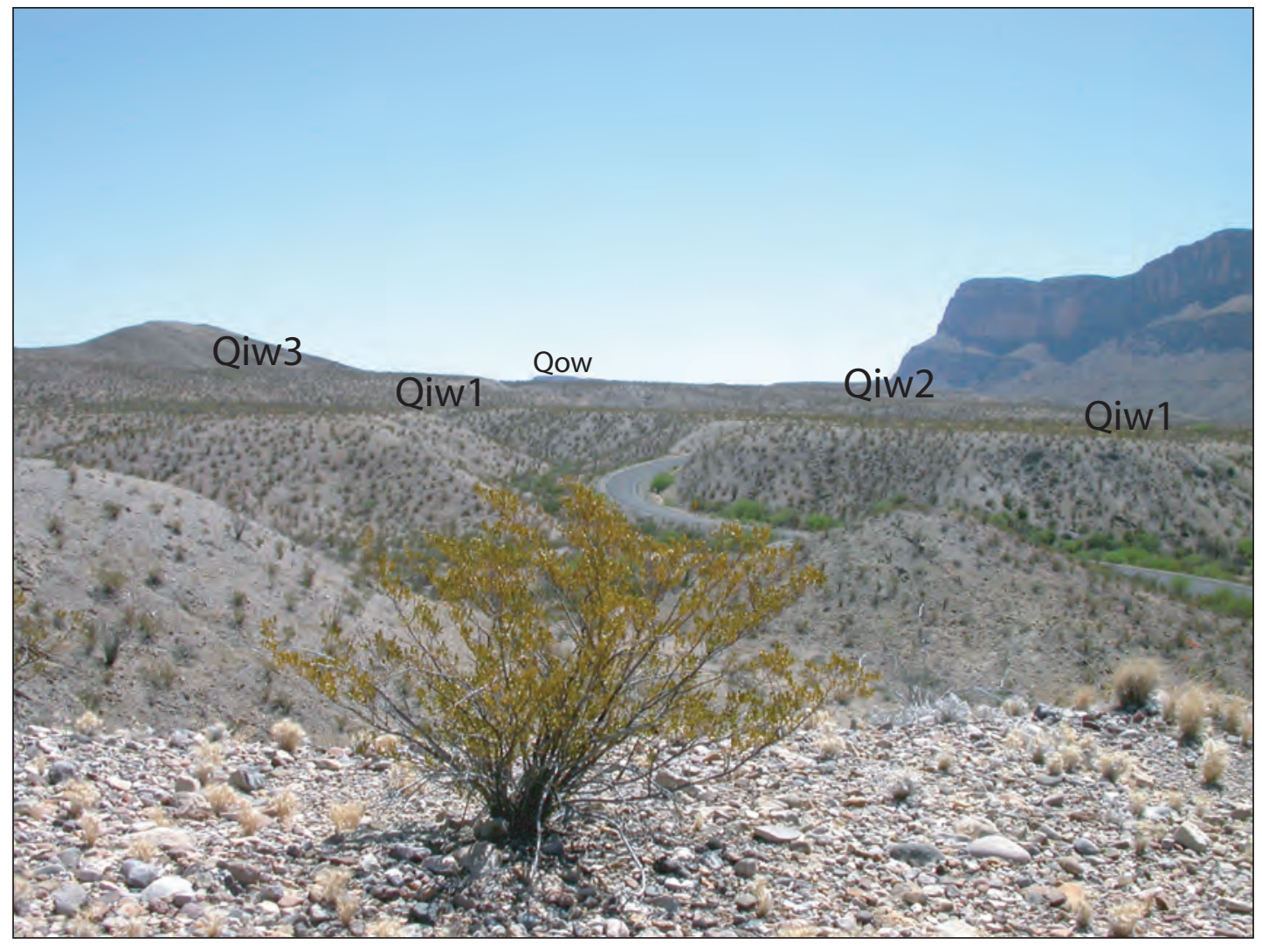

Figure 2-5. Rio Grande terraces near Santa Elena Canyon Overlook, southwest Big Bend National Park (the overlook is just out of view to the right, on the Qiw1 terrace). Three levels of terraces thought to range from middle to late Pleistocene in age (Qiw3, Qiw2, and Qiw1) are visible in this photograph. An older, higher terrace (0ow) is barely visible far in the distance, near the center of the photograph. 

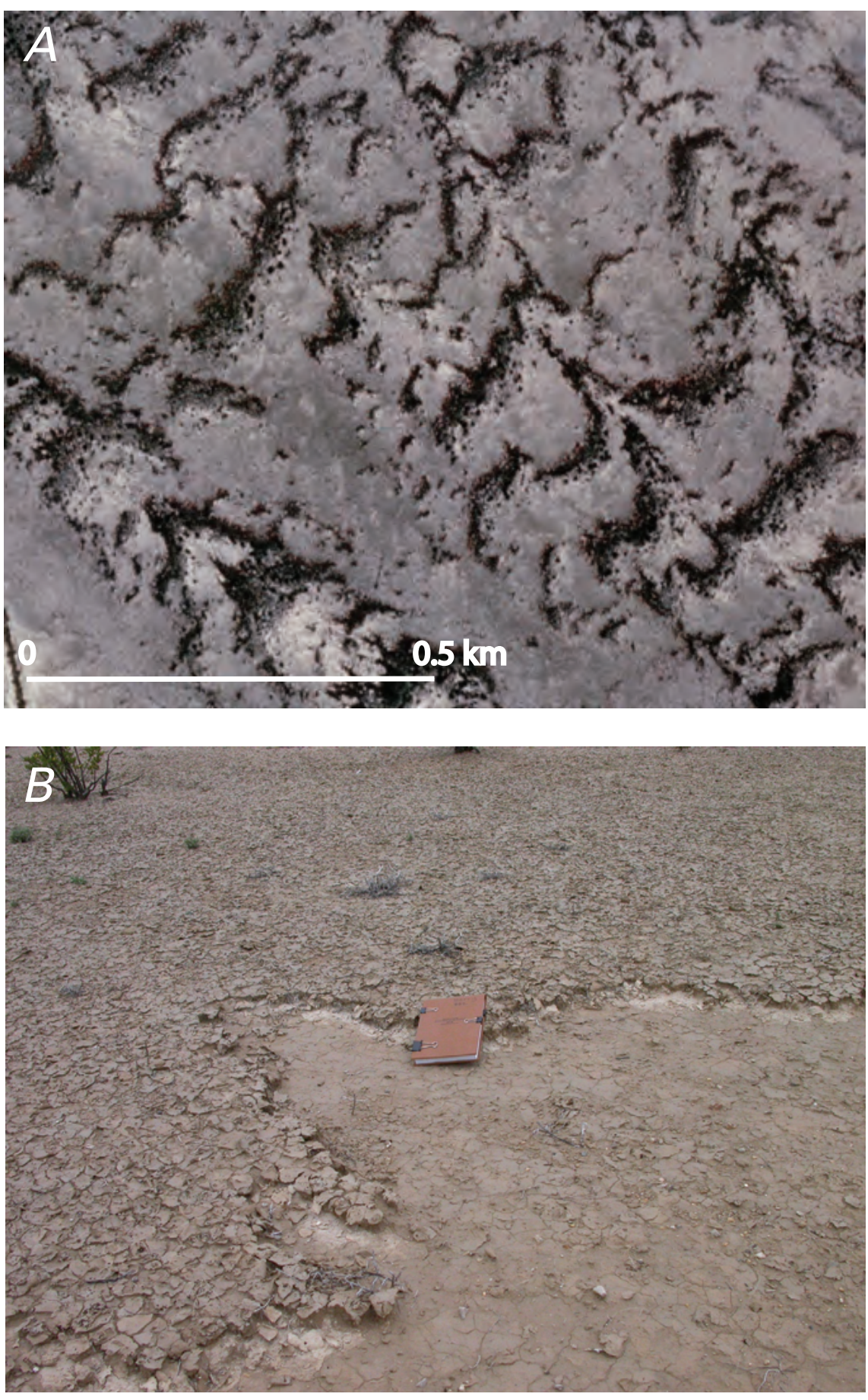

Figure 2-6 (left and facing page). Banded vegetation and surface characteristics of deposits on which the banded vegetation forms. A, Portion of a color-infrared digital orthophoto image of the southwest quarter of Persimmon Gap quadrangle, in the northernmost part of the park. Image shows aerial view of banded vegetation (dark bands) separated by lighter colored interband areas where vegetation cover is relatively sparse. $B$, Mud cracked surface crust on a young alluvial surface (Oya1) in an interband area near Dog Canyon. Crust has been partly eroded by surface wash. Notebook (14 cm wide) for scale. $C$, Interband area adjacent to the vegetation band shown in figure $2-6 D$, formed on an intermediate-age alluvial surface (Qia). Pavement is moderately packed and uniform with moderately varnished clasts. $D$, Relatively thick vegetation growing in a vegetation band adjacent to the area shown in figure $2-6 C$. Ground surface within the vegetation band is relatively rough and lacks desert pavement. 

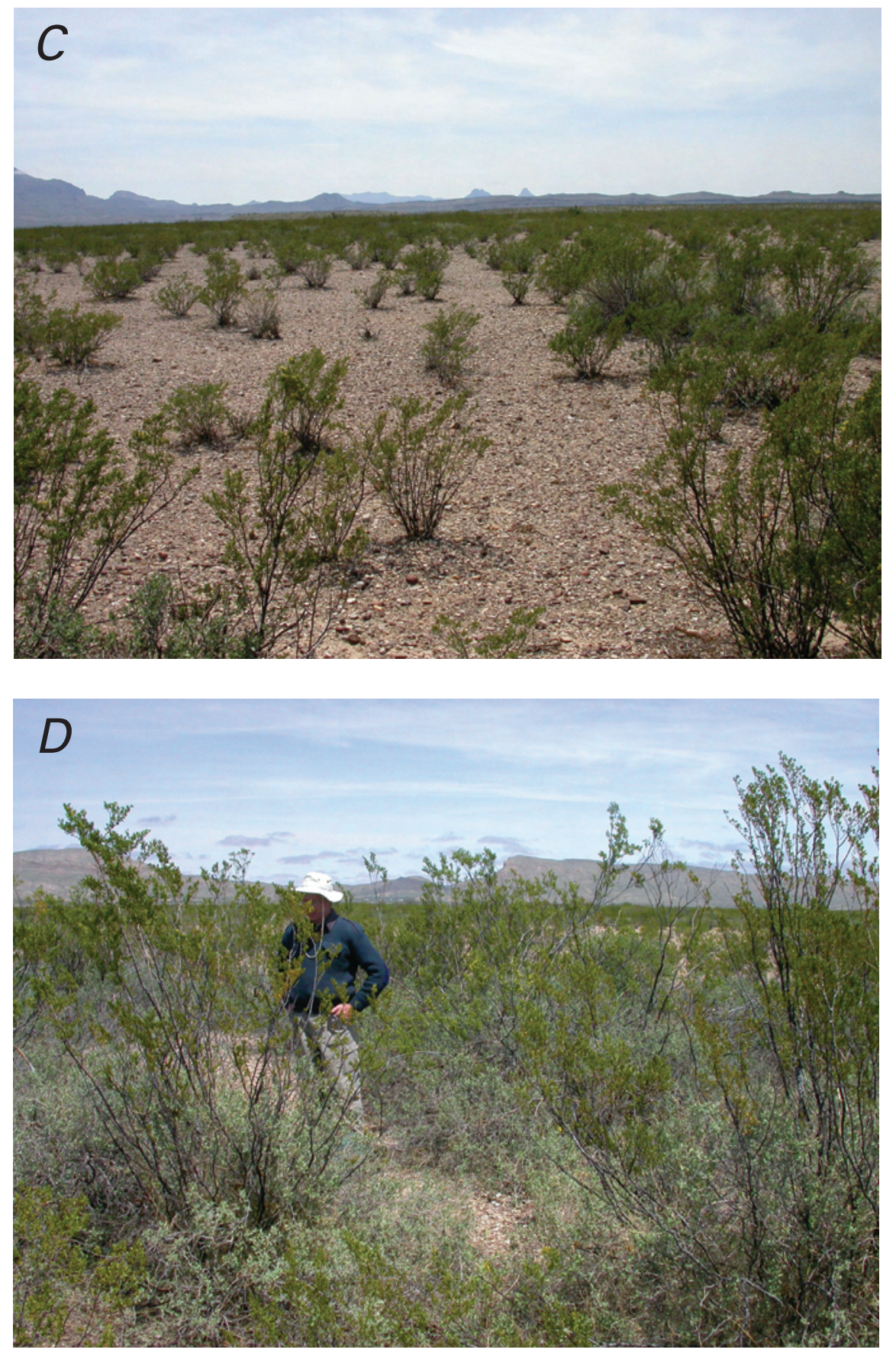


\section{Summary}

The long and complex Quaternary geologic and climatic history of Big Bend National Park is reflected in the multiple levels of pediment-capping gravel deposits, alluvial-fan deposits, and stream and river alluvium that cover much of the park. Erosion of the landscape has been extensive during the Quaternary period. The Rio Grande fluvial system has been dominated by long-term incision since it was established, probably in the late Pliocene to early Pleistocene. Periodically, incision was disrupted by episodes of aggradation, evidence of which is reflected in the multiple levels of coarse-gravel terrace deposits preserved along the Rio Grande. These fluctuations in the depositional regime likely were associated with periodic changes in climate and river hydrology.

\section{Acknowledgments}

We thank Michael Machette and Marith Reheis for their thoughtful and constructive reviews of this manuscript, and our coworkers on the Big Bend project for their support.

\section{References Cited}

Aguiar, M.R., and Sala, O.E., 1999, Patch structure, dynamics and implications for the functioning of arid ecosystems: Tree, v. 14, no. 7, p. 273-277.

Birkeland, P.W., 1999, Soils and geomorphology (3d ed.): New York, Oxford University Press, 430 p.

Bull, W.B., 1991, Geomorphic responses to climatic change: New York, Oxford University Press, 326 p.

Collins, E.W., Muehlberger, W.R., and Dickerson, P.W., 2007, Geologic map of the Glenn Spring Quadrangle, Big Bend National Park, Texas: University of Texas at Austin, Bureau of Economic Geology Open-file map, scale 1:24,000, 2 sheets.

Connell, S.D., Hawley, J.W., and Love, D.W., 2005, Late Cenozoic drainage development in the southwestern Basin and Range of New Mexico, southeasternmost Arizona, and western Texas, in Lucas, S.G., Morgan, G.S., and Zeigler, K.E., eds., New Mexico's ice ages: Albuquerque, N. Mex., New Mexico Museum of Natural History and Science Bulletin 28 , p. $125-150$.

Dethier, D.P., 2001, Pleistocene incision rates in the western United States calibrated using Lava Creek B tephra: Geology, v. 29, no. 9, p. 783-786.
Dickerson, P.W., and Muehlberger, W.R., 1994, Basins in the Big Bend segment of the Rio Grande rift, Trans-Pecos Texas, in Keller, G.R., and Cather, S.M., eds., Basins of the Rio Grande rift-Structure, stratigraphy, and tectonic setting: Geological Society of America Special Paper 291, p. 283-297.

Elias, S.A., 1997, The ice-age history of southwestern National Parks: Washington, D.C., Smithsonian Institution Press, 200 p.

Machette, M.N., 1985, Calcic soils of the southwestern United States, in Weide, D.L., ed., Soils and Quaternary geology of the southwestern United States: Geological Society of America Special Paper 203, p. 1-21.

Maxwell, R.A., Lonsdale, J.T., Hazzard, R.T., and Wilson, J.A., 1967, Geology of Big Bend National Park, Brewster County, Texas: University of Texas at Austin, Bureau of Economic Geology Publication 6711, 320 p.

Neuendorf, K.K.E, Mehl, J.P., Jr., and Jackson, J.A., 2005, Glossary of geology (5th ed.): Alexandria, Va., American Geological Institute.

Ogg, J., comp., 2004, Overview of global boundary stratotype sections and points (GSSPs): International Commission on Stratigraphy, http://www.stratigraphy.org/gssp.htm.

Saco, P.M., Willgoose, G.R., and Hancock, G.R., 2006, Ecogeomorphology and vegetation patterns in arid and semiarid regions: Hydrology and Earth System Sciences Discussions, v. 3, p. 2,559-2,593.

Stevens, J.B., 1969, Geology of the Castolon area, Big Bend National Park, Brewster County, Texas: Austin, Tex., University of Texas, Ph.D. dissertation, 129 p.

Stevens, J.B., 1988, Mid-Tertiary and Pleistocene sections, Sotol Vista to Cerro Castellan, Big Bend National Park, southwestern Brewster County, Trans-Pecos Texas, in Hayward, O.T., ed., South-central section of the Geological Society of America. Centennial field guide, v. 4: Geological Society of America, p. 429-434.

Stevens, J.B., and Stevens, M.S., 1990, Stratigraphy and major structural-tectonic events along and near the Rio Grande, Trans-Pecos Texas and adjacent Chihuahua and Coahuila, Mexico, in Dickerson, P.W., Stevens, M.S., and Stevens, J.B., eds., Geology of the Big Bend, and Trans-Pecos, Texas: South Texas Geological Society field trip guidebook [for the American Association of Petroleum Geologists annual meeting, San Antonio, Tex., 1989], p. 73-116.

Stevens, M.S., 1977, Further study of the Castolon local fauna (early Miocene), Big Bend National Park, Texas: Texas Memorial Museum, Pearce-Sellards Series, no. 28, 69 p. 
Stevens, M.S., and Stevens, J.B., 1989, Neogene-Quaternary deposits and vertebrate faunas, Trans-Pecos Texas, in Busbey, A.B., III, and Lehman, T.M., eds., Wilson, J.A., coordinator, Vertebrate paleontology, biostratigraphy and depositional environments, Latest Cretaceous and Tertiary, Big Bend Area, Texas [guidebook for the Big Bend field trip]: Society of Vertebrate Paleontology [annual meeting, Austin, Tex., 1989], p. 67-90.

Stevens, M.S., and Stevens, J.B., 2003, Carnivora (Mammalia, Felidae, Canidae, and Mustelidae) from earliest Hemphillian Screw Bean local fauna, Big Bend National Park, Brewster County, Texas: Bulletin of the American Museum of Natural History, v. 13, no. 279, p. 177-211.

Stevens, M.S., Stevens, J.B., and Dawson, M.R., 1969, New early Miocene formation and vertebrate local fauna, Big Bend National Park, Brewster County, Texas: Texas Memorial Museum, Pearce-Sellards Series, no. 15, 53 p.

Thurwachter, J.E., 1984, Sedimentology of Neogene basin-fill deposits, lower Tornillo Creek area, Big Bend National Park, Texas: Austin, Tex., University of Texas, M.A. thesis, 86 p.

U.S. Geological Survey Geologic Names Committee, 2007, Divisions of geologic time-Major chronostratigraphic and geochronologic units: U.S. Geological Survey Fact Sheet 2007-3015, 2 p.

Wakelin-King, G.A., 1999, Banded mosaic ('tiger bush') and sheetflow plains-A regional mapping approach: Australian Journal of Earth Sciences, v. 46, p. 53-60. 


\title{
3. Volcanic Geology of Several Prominent Outcrops in the Western Part of Big Bend National Park
}

\author{
By Daniel P. Miggins, Minghua Ren, and Elizabeth Y. Anthony
}

\section{Abstract}

Big Bend National Park (BBNP) contains a diverse suite of volcanic and plutonic rocks. Ongoing geologic mapping, geochronology, and geochemical studies have focused on the timing and geological relationships associated with these volcanic and plutonic rocks. New geochemical data and ${ }^{40} \mathrm{Ar} /{ }^{39} \mathrm{Ar}$ age determinations aid in our understanding of the volcanic stratigraphy in the western part of BBNP. This study focused on volcanic rocks in four areas in western BBNP: (1) Blue Creek Ranch, (2) Tule Mountain, (3) Mule Ear Peaks, and (4) Cerro Castellan. Geochronological data indicate that volcanism within the western part of the park occurred from 46.5 to $29 \mathrm{Ma}$. The oldest volcanic rocks in the western part of BBNP are the Alamo Creek lavas dated at 46.5 Ma. Samples from the Ash Spring Basalt yielded ${ }^{40} \mathrm{Ar} /{ }^{39} \mathrm{Ar}$ ages of about $42 \mathrm{Ma}$. The Alamo Creek and Ash Spring Basalts are difficult to distinguish from one another and are similar both petrographically and geochemically. The Bee Mountain Basalt is dated at 33.7 Ma and has a variable thickness in western BBNP. We identified lava flows above the Mule Ear Spring Tuff and below the Tule Mountain Trachyandesite; they are likely correlative with the Bee Mountain Basalt, indicating the eruption of the basalt was interrupted by the Mule Ear Spring Tuff. The Mule Ear Spring Tuff, a regional ash-flow tuff dated at 33.6 Ma, is a significant marker unit within the Chisos Group. The Tule Mountain Trachyandesite is dated at approximately $33 \mathrm{Ma}$ at Tule Mountain, but we have obtained ${ }^{40} \mathrm{Ar} /{ }^{39} \mathrm{Ar}$ ages of 30.3 Ma for a widespread unit previously mapped as Tule Mountain Trachyandesite south and west of Tule Mountain. The Wasp Spring and Burro Mesa members of the Burro Mesa Formation are dated at 29.4 Ma and represent the last major volcanic eruptions in BBNP west of the Chisos Mountains.

\section{Introduction}

The park contains a diverse suite of volcanic and plutonic rocks representing the easternmost extension of the Trans-Pecos magmatic province (fig. 3-1) (Barker, 1977). A number of geological studies have been conducted within and surrounding BBNP to understand the volcanic and plutonic rocks with respect to their stratigraphic and tectonic setting (Maxwell and others, 1967; Barker, 1977, 1987; Henry and Price, 1984; Barker and others, 1986; Henry and others, 1991; White and others, 2006). These studies provide a solid foundation for further geochemical and geochronological studies.

Limited ${ }^{40} \mathrm{Ar} /{ }^{39} \mathrm{Ar}$ and numerous K/Ar ages poorly constrained the volcanic and plutonic history (Maxwell and others, 1967; Laughlin and others, 1982; Henry and McDowell, 1986). New geologic mapping, ${ }^{40} \mathrm{Ar} /{ }^{39} \mathrm{Ar}$ geochronology, and geochemical data are helping us better understand the volcanic stratigraphy and timing of the numerous intrusive rocks throughout BBNP as they relate to the park's geologic history. Volcanic stratigraphic units in BBNP include the Chisos Group (Henry and Davis, 1996), the South Rim Formation (White and others, 2006), and the Burro Mesa Formation (Benker, 2005; White and others, 2006).

This paper discusses some prominent outcrops in BBNP, mainly along Ross Maxwell Scenic Drive, and presents new geochronological and geochemical data of selected volcanic samples from the Chisos Group and Burro Mesa Formation.

\section{Stratigraphy}

This report focuses on the volcanic rocks in the western part of BBNP, which includes the Eocene-Oligocene Chisos Group of Henry and Davis (1996), and Oligocene Burro Mesa Formation of Benker (2005) and White and others (2006). The rocks of the South Rim are not discussed here and we generally follow Benker (2005) and White and others (2006) in restricting these rocks to sources in the Pine Canyon caldera complex of the high Chisos Mountains (fig. 3-1). 
Figure 3-1. Landsat 7 image showing Big Bend National Park and surrounding regions. See figure $3-4$ for detail of boxed region. TPMP, Trans-Pecos magmatic province; BBNP, Big Bend National Park; R, Roy's Peak; PM, Peña Mountain; BCR, Blue Creek Ranch; MG, Mariscal Mountain gabbro; SQ, Sierra Quemada; P, Punta de la Sierra; ME, Mule Ear Peaks.

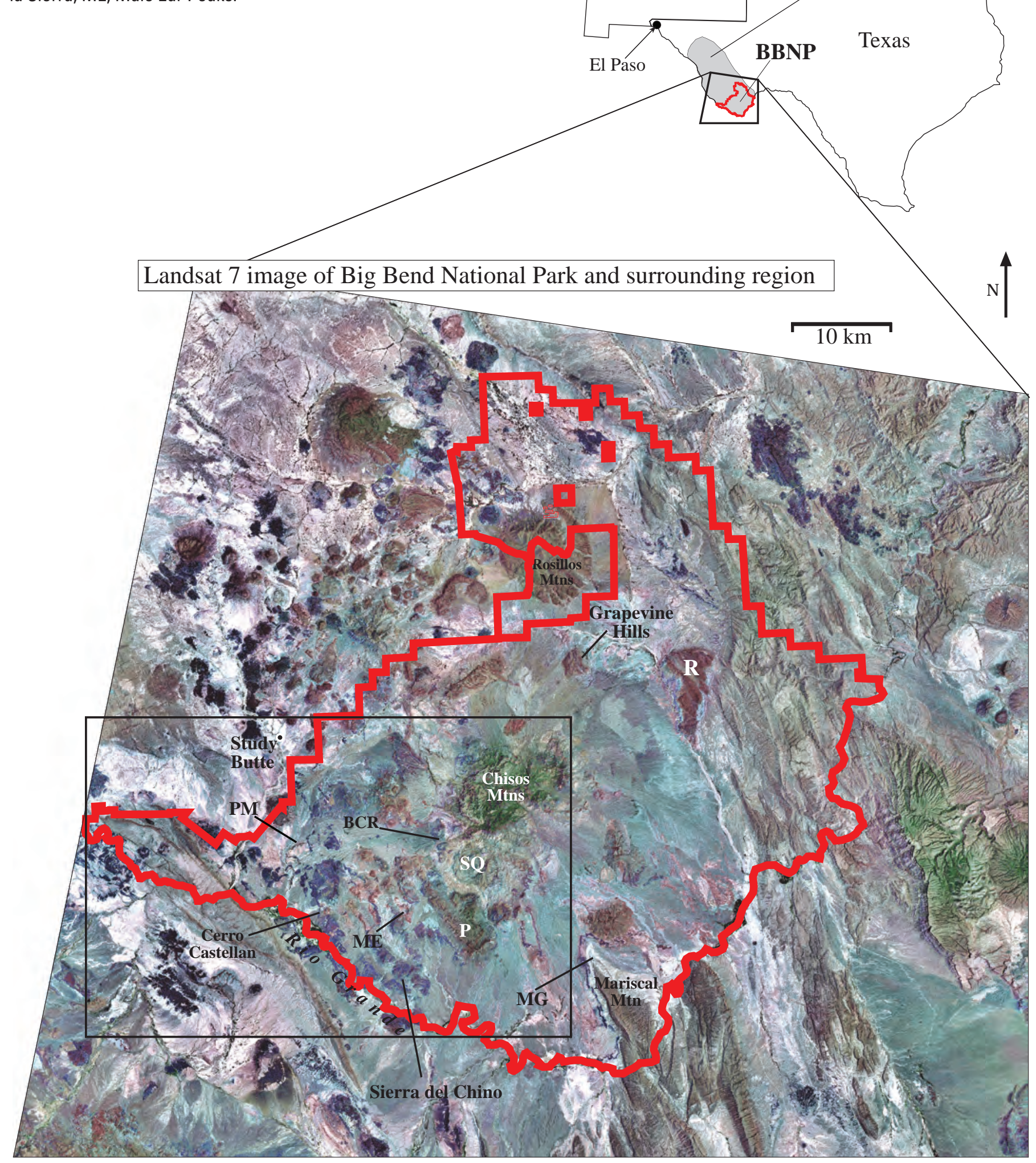


The Chisos Formation was originally defined by Maxwell and others (1967) to include (in ascending order), the Alamo Creek Basalt, Ash Spring Basalt, Bee Mountain Basalt, Mule Ear Spring Tuff, and Tule Mountain Trachyandesite. These members are separated by undifferentiated, tuffaceous sedimentary rocks of the Chisos Formation including conglomerate, sandstone, mudstone, tuff, tuffaceous sandstone and clay, and minor lacustrine limestone. Henry and Davis (1996) noted that many of the volcanic flows that Maxwell and others (1967) designated as members of the Chisos Formation were widespread, prominent, identifiable units in the Trans-Pecos region, and thus, they subsequently renamed this formation as the Chisos Group; in addition, most of its members (Alamo Creek Basalt, Bee Mountain Basalt, Mule Ear Spring Tuff, and Tule Mountain Trachyandesite) were renamed formations. The Ash Spring Basalt of Maxwell and others (1967) was not recognized outside of BBNP, and therefore, was not included as a formation in the Chisos Group by Henry and Davis (1996). The volcanic rocks within the Chisos Group are mafic and felsic rocks that are exposed mostly in the western part of BBNP.

Henry and Davis (1996) reported that the Alamo Creek Basalt contained multiple flows of about $47 \mathrm{Ma}$ and of highly variable composition ranging from basalt, through trachybasalt and basaltic trachyandesite, to trachyandesite. Several samples of Alamo Creek Basalt collected within the park are geochemically classified as trachyandesites (figs. 3-2 and $3-3)$, but these flows have been reported to be variable in composition (Maxwell and others, 1967, Carman and others, 2003). Exposures of the Alamo Creek Basalt are limited to the western half of BBNP, where they generally unconformably overlie prevolcanic Upper Cretaceous and Lower Tertiary sedimentary rocks. The Alamo Creek Basalt has been reported to contain up to six individual flows (Carman and others, 2003). The thickest sections of Alamo Creek Basalt are exposed west of the Mule Ear Peaks and Punta de la Sierra (fig. 3-1). We collected and analyzed several samples of the Alamo Creek Basalt from locations in western BBNP. These samples yielded ${ }^{40} \mathrm{Ar} /{ }^{39} \mathrm{Ar}$ ages of $46.5 \mathrm{Ma}$, which is similar to ages of this unit reported by Henry and Davis (1996).

The next unit above the Alamo Creek Basalt consists of lavas mapped by Maxwell and others (1967) as the Ash Spring Basalt (fig. 3-2B). The Ash Spring Basalt is petrographically and geochemically similar to the Alamo Creek Basalt; these two units can be difficult to distinguish in outcrop. Maxwell and others (1967) described the Ash Spring Basalt as two or more flows of porphyritic basalt with abundant plagioclase phenocrysts. We collected a sample of the Ash Spring Basalt along the Ross Maxwell Scenic Drive that yielded a ${ }^{40} \mathrm{Ar} /{ }^{39} \mathrm{Ar}$ age of $42.5 \mathrm{Ma}$.

The thickest mafic lavas of the Chisos Group include flows of Bee Mountain Basalt. Henry and Davis (1996) defined the Bee Mountain Basalt west of BBNP to include at least five flows below the Mule Ear Spring Tuff and three or four flows above the Mule Ear Spring Tuff that range in age from 34 to $33 \mathrm{Ma}$ with a composition ranging from trachybasalt to basalt. Exposures of the Bee Mountain Basalt generally form steep cliffs, and the flows contain abundant plagioclase. Several samples that we collected from flows below the Mule
Ear Spring Tuff have similar compositions to those described by Henry and Davis (1996), and our ${ }^{40} \mathrm{Ar} /{ }^{39} \mathrm{Ar}$ ages of $33.7 \mathrm{Ma}$ are similar to theirs. A series of lavas in BBNP above the Mule Ear Spring Tuff, but below the Tule Mountain Trachyandesite, are likely correlative to the Bee Mountain lavas based on trace element analyses by Turner and others (in press). These upper Bee Mountain lavas are in the same stratigraphic position outside of BBNP as those described by Henry and Davis (1996).

The Mule Ear Spring Tuff was defined by Henry and Davis (1996) to include a single rhyolite flow with an age of about 33 Ma. Exposures of this tuff range from non-welded to moderatelywelded with varying amounts of lithic clasts and pumice. Unlike most tuffs exposed in BBNP, the Mule Ear Spring Tuff has a nearly uniform thickness ranging from 6-8 $\mathrm{m}$. Several samples of this tuff yield consistent ages of $33.6 \mathrm{Ma}$, similar to those reported by Henry and Davis (1996) and Henry and others (1998).

The Tule Mountain Trachyandesite was defined by Henry and Davis (1996) in areas west of BBNP as a single flow of intermediate to moderately silicic composition lava flow dated at about 33 Ma. Benker (2005) indicated that rocks mapped as Tule Mountain Trachyandesite by Maxwell and others (1967) consist of lava flows, dikes, and small volcanic plugs (fig. $3-2 B)$. However, our study and findings by Turner and others (in press) indicate some of these rocks may be misidentified. Rocks from Burro Mesa, Tule Mountain, and Sierra Aguja have similar trace element and whole rock compositions (Turner and others, in press) and have been dated at around approximately $33 \mathrm{Ma}$. In contrast, rocks southwest of Tule Mountain to Sierra del Chino (fig. 3-4) are compositionally distinct from the approximately 33 Ma rocks (Turner and others, in press), and ${ }^{40} \mathrm{Ar} /{ }^{39} \mathrm{Ar}$ ages indicate they are much younger at $30.3 \mathrm{Ma}$. Further studies are needed to fully comprehend the relationship these two rocks share with other Chisos Group rocks.

The undifferentiated tuffaceous sedimentary rocks represent a significant part of the Chisos Group stratigraphy (fig. $3-2 B$ ). Exposures of these tuffs range in thickness from a few to hundreds of meters and were deposited between the major lava flows found throughout the western half of BBNP. Deposits of the Chisos tuffs contain one or more of the following in any given outcrop: air-fall deposits, tuffaceous sediments, conglomerates, and reworked and ponded tuffs, such as those exposed at Cerro Castellan and west of Mule Ear Peaks (fig. 3-1).

The Burro Mesa Formation of Benker (2005) and White and others (2006) (fig. 3-2A) includes the Wasp Spring member and Burro Mesa Rhyolite member (fig. 3-2B). The Wasp Spring member is one of the more easily recognizable volcanic rocks. Typical exposures of this rock vary in color from bright orange, to gray, to sometimes white, containing 5-60 percent lithic clasts. The Wasp Spring member reaches thicknesses of $200 \mathrm{~m}$ or more, with the thickest exposures at Goat Mountain (fig. 3-4A). The Burro Mesa Rhyolite member consists of lava flows and associated vents. Typically, lavas of the Burro Mesa are light to dark gray and contain variable amounts of sanidine and riebeckite. Most exposures of the Burro Mesa Rhyolite show rheomorphic folding and exposed flows can be greater than $50 \mathrm{~m}$ thick; ${ }^{40} \mathrm{Ar} /{ }^{39} \mathrm{Ar}$ ages for the Wasp Spring and Burro Mesa Rhyolite members are about 29.4 Ma. 


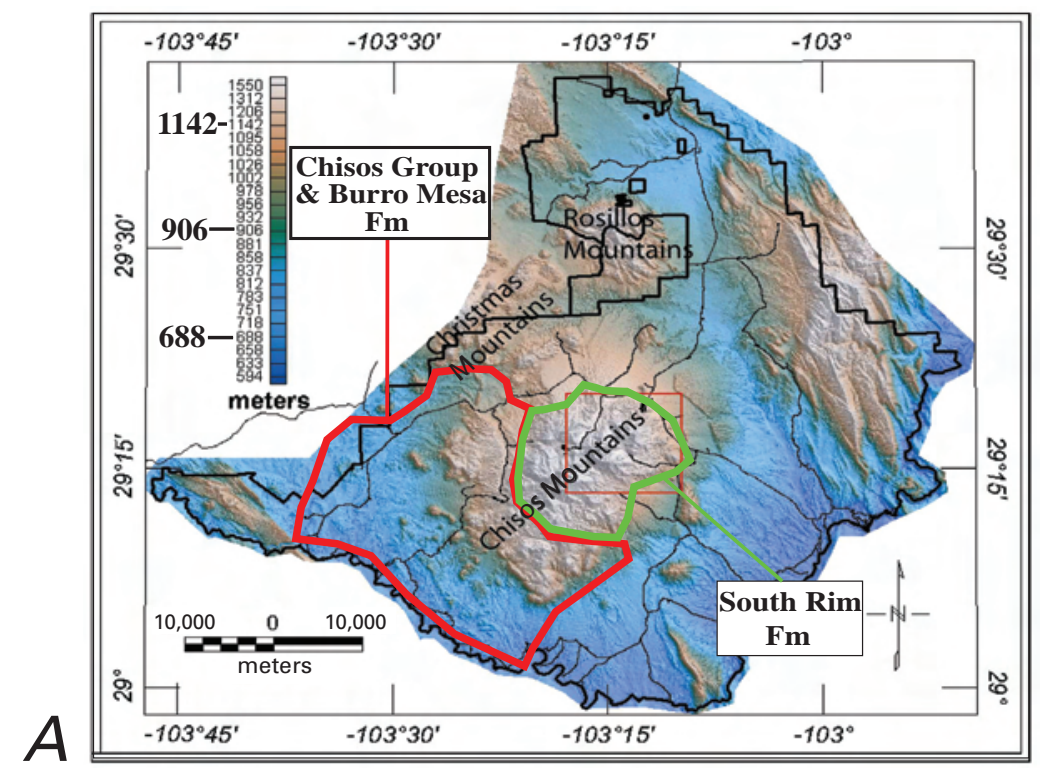

Figure 3-2. Location map and stratigraphic composite section for the Chisos Group and South Rim Formations. $A$, False color relief map of Big Bend National Park. Generalized geographic locations for the Chisos, Burro Mesa, and South Rim Formations; modified from Drenth (2005). $B$, Generalized volcanic stratigraphy of studied area. The ${ }^{40} \mathrm{Ar} /{ }^{39} \mathrm{Ar}$ ages are from this study.

Ages (Ma)

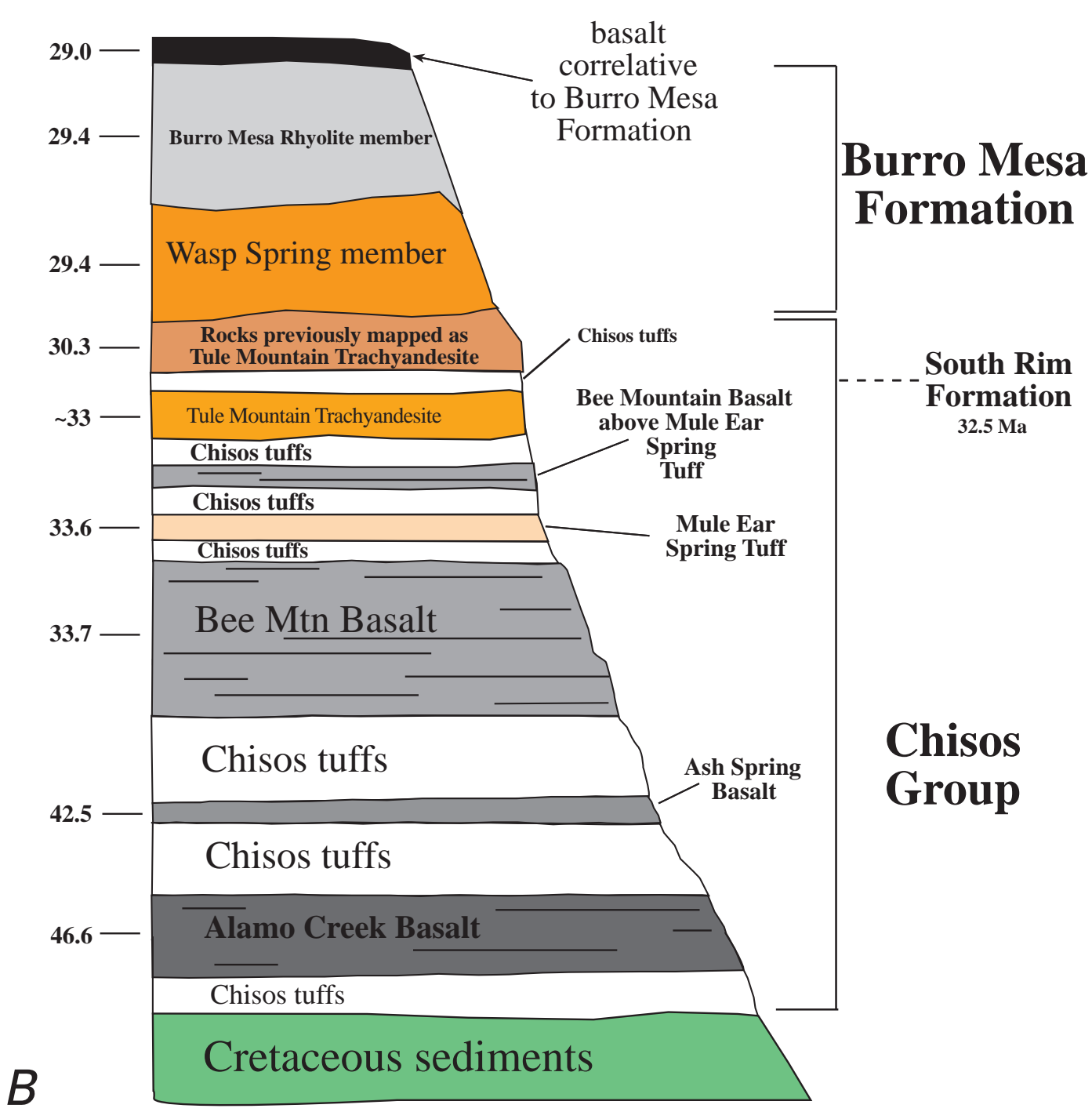




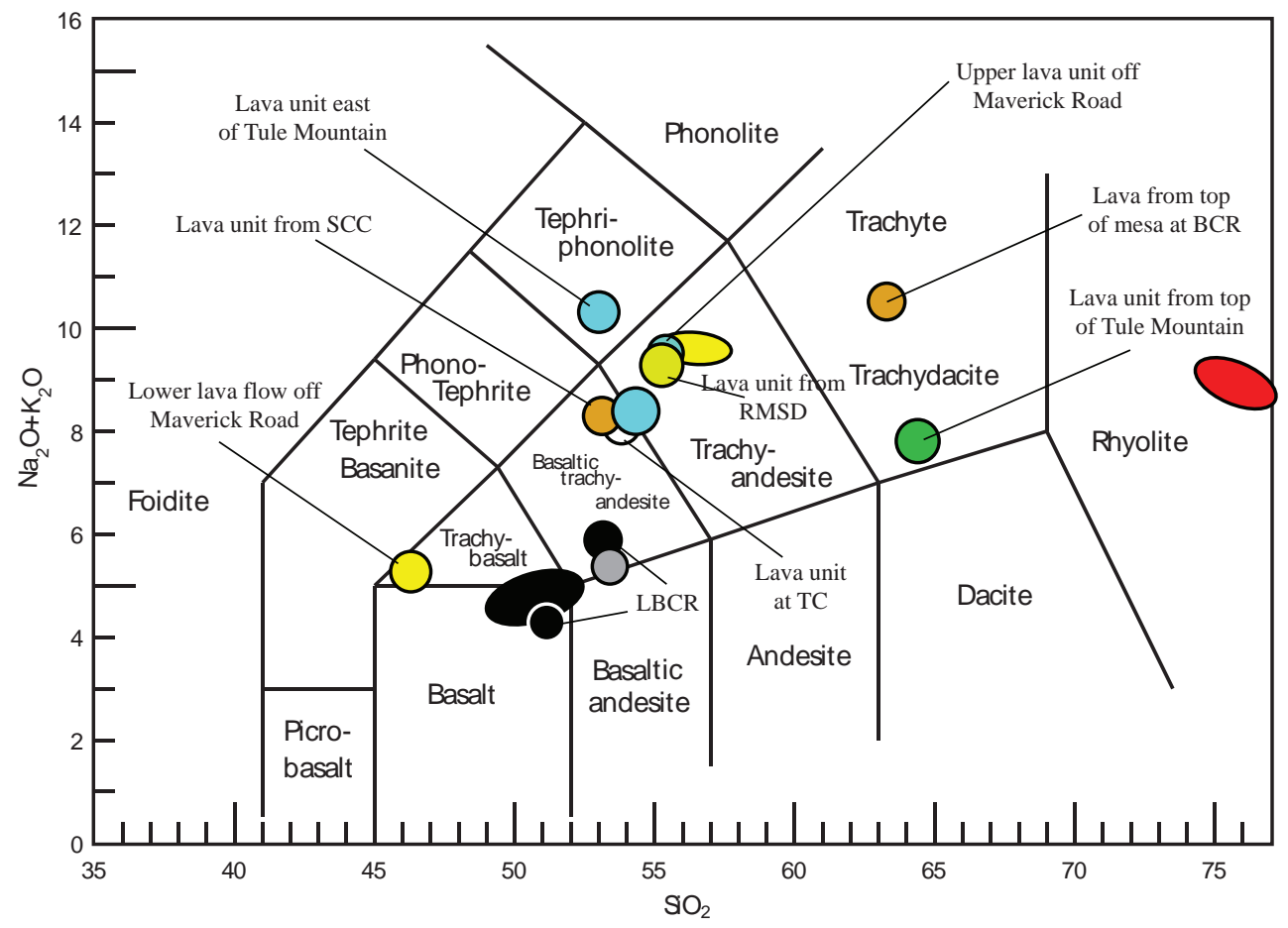

\section{EXPLANATION}

\section{Rock type}

Burro Mesa Rhyolite

Rocks previously mapped as Tule Mountain Trachyandesite

Tule Mountain Trachyandesite

Bee Mountain Basalt above Mule Ear Spring Tuff

Bee Mountain Basalt below Mule Ear Spring Tuff

Ash Spring Basalt

Alamo Creek Basalt
Age (Ma)

29.4

30.3

$\sim 33$

33.6

33.7

42.5

46.6

Figure 3-3. Total alkali versus silica diagram showing the major rock types discussed in the text. This diagram illustrates the diversity of rock types in the western half of Big Bend National Park, as well as the variation among rocks of similar age. The explanation indicates the type of unit and age or age range for each sample. The Alamo Creek, Tule Mountain, and unknown units (may be Alamo Creek, Ash Spring, or Bee Mountain lavas) show the greatest geochemical differences. For example, the Tule Mountain units have compositions ranging from basaltic-trachyandesite to trachydacite to trachyte. BCR, Blue Creek Ranch; RMSD, Ross Maxwell Scenic Drive; TC, Tuff Canyon; LBCR, lower Blue Creek Ranch lavas; SCC, Southern Cerro Castellan. (From LeBas and others, 1986.) 


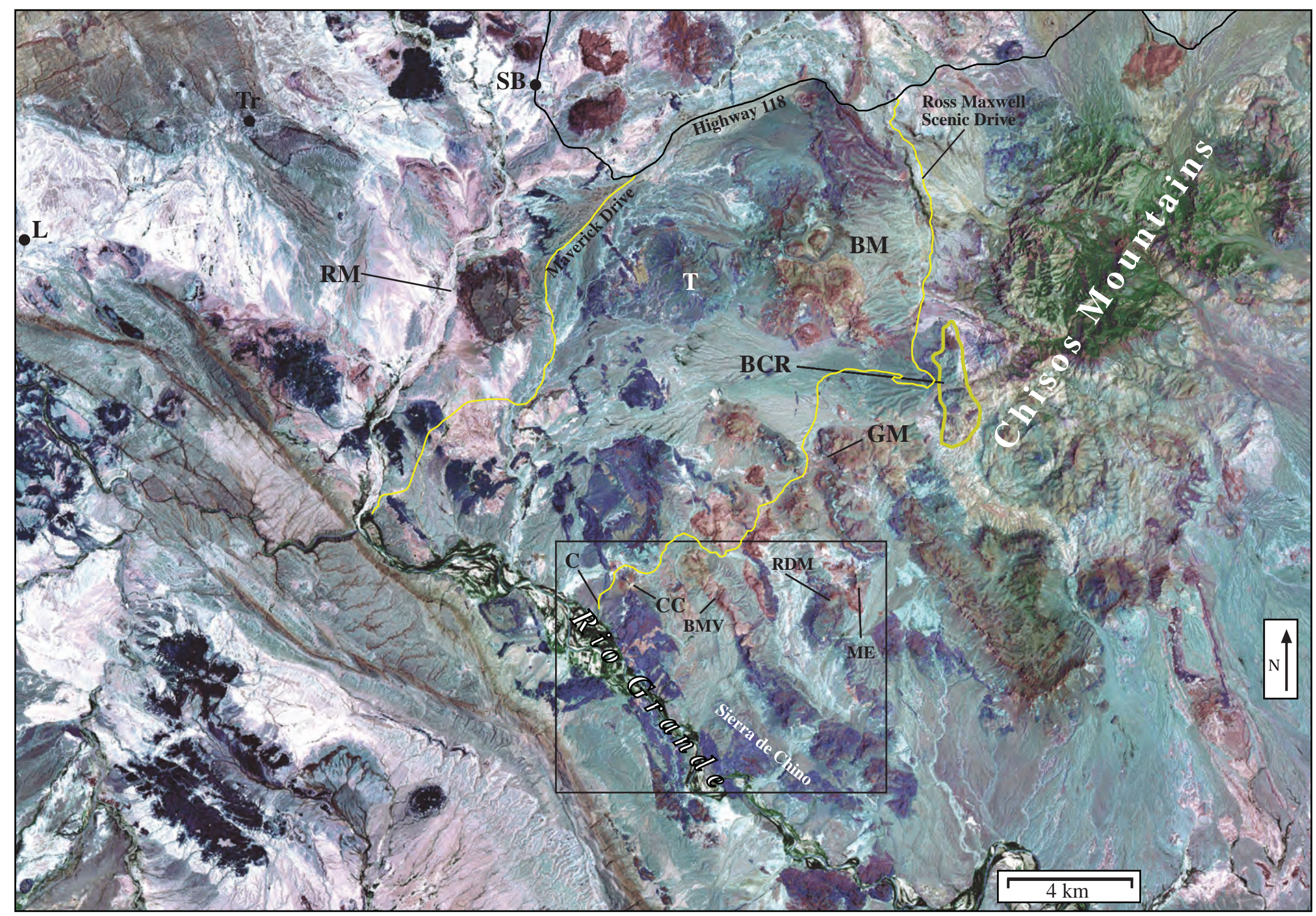

Figure 3-4. Landsat 7 image of the western half of Big Bend National Park indicating some of the major features and geologic units discussed in the text. In general terms, the red and light colored rocks are felsic in composition and darker rocks are mafic in composition. See figure 3-8C for detail of boxed region. SB, Study Butte; L, Lajitas; Tr, Terlingua; RM, Rattlesnake Mountain; BM, Burro Mesa; T, Tule Mountain; BCR, Blue Creek Ranch; C, Castolon; CC, Cerro Castellan; BMV, Burro Mesa vent area; ME, Mule Ear Peaks; RDM, Round Mountain; GM, Goat Mountain. 


\section{Volcanic Stratigraphy}

\section{Blue Creek Ranch Overlook}

A set of geologic outcrops that we have studied includes exposures near the Blue Creek Ranch Overlook on the Ross Maxwell Scenic Drive (figs. 3-1 and 3-4A). Maxwell and others (1967) mapped the outcrops in the Blue Creek Ranch area, from lower to upper units, as Bee Mountain Basalt, Mule Ear Spring Tuff, and Tule Mountain Trachyandesite.

The lowermost exposed unit at Blue Creek Ranch is the Bee Mountain Basalt. Above the Bee Mountain Basalt are thick deposits of lahars and conglomerates (fig. 3-5). The conglomerate contains clasts of a variety of volcanic rock types that range from a few millimeters to $50 \mathrm{~cm}$ in diameter. Unconformably overlying the conglomerates and lahar deposits are thick sequences of ash-flow tuffs (figs. 3-5A, $B$ ). A sequence of three ash-flow tuffs is exposed on the north side of Blue Creek. The middle tuff yielded a ${ }^{40} \mathrm{Ar} /{ }^{39} \mathrm{Ar}$ age from sanidine of 32.1 Ma. The limited aerial extent of these tuffs suggests that they were erupted from a local source, and the age (32.1 Ma) is similar to volcanic and intrusive rocks associated with the South Rim Formation. We suggest that the rhyolite tuffs exposed in the Blue Creek area may represent outflow tuffs related to the South Rim Formation, but further geochemical analyses and detailed geologic mapping are needed to correlate these rocks.

The uppermost volcanic rocks were previously mapped by Maxwell and others (1967) as the Tule Mountain Trachyandesite (fig. 3-5D) but are dated at $30.3 \mathrm{Ma}$ and are chemically similar to other rocks discussed earlier (Turner and others, in press). A rhyolite dike exposed on the north side of Blue Creek yielded a ${ }^{40} \mathrm{Ar} /{ }^{39} \mathrm{Ar}$ age of $29.0 \mathrm{Ma}$, cross-cuts this section, and represents some of the youngest intrusive activity found in BBNP (fig. 3-5C).

\section{Mule Ear Peaks Viewpoint and Round Mountain Section}

The Mule Ear Peaks are visible just off Ross Maxwell Scenic Drive (Mule Ears Viewpoint) and are one of the more prominent geologic features in BBNP. Field observations suggest that the Mule Ear Peaks are dominantly Burro Mesa Rhyolite member of the Burro Mesa Formation and represent the last major eruptive rhyolite found throughout southwestern BBNP (fig. 3-3) with an age of 29.4 Ma (Miggins and others, 2004, 2006). Although not apparent from the Mule Ears Viewpoint, there is a thick stratigraphic section of the Chisos Group and overlying Burro Mesa Formation exposed at Round Mountain, several kilometers south of the viewpoint (fig. $3-7 B)$. This section is significant because the Alamo Creek Basalt is about $100 \mathrm{~m}$ thick and represents one of the thickest sections of the unit in the entire park. This thick accumulation of lava suggests this area was a paleo-topographic valley, drainage, or depression during eruption of the Alamo Creek Basalt. Tuffaceous, sedimentary deposits of the Chisos Group above the Alamo Creek Basalt are also thick, indicating this area remained a lowland during their deposition. These deposits consist of about $500 \mathrm{~m}$ of air-fall tuff and ponded, reworked units comprising massive tuff beds intercalated with conglomerate and tuffaceous sandstone (fig. 3-7).

Above the Chisos Group tuffaceous and sedimentary rocks is a massive section of Bee Mountain Basalt (fig. 3-7). Stratigraphically above the Bee Mountain Basalt are a series of trachyandesite lava flows (fig. 3-7). It is presently unclear if these trachyandesites belong to the approximately $33 \mathrm{Ma}$ Tule Mountain Trachyandesite as defined by Henry and Davis (1996), or are part of the 30.3 Ma trachyandesite previously mapped as the Tule Mountain Trachyandesite by Maxwell and others (1967). The Burro Mesa Formation caps the top of Round Mountain (fig. 3-7).

\section{Tule Mountain}

The volcanic rocks exposed at Tule Mountain in stratigraphic order are Chisos tuffs, Ash Spring Basalt, Chisos tuffs and conglomerates, Mule Ear Spring Tuff, and the Tule Mountain Trachyandesite (fig. 3-6). Maxwell and others (1967) mapped flows at the base of Tule Mountain as Ash Spring Basalt (figs. 3-2 and 3-6). In this section, the Ash Spring Basalt consists of one to three lava flows. Above the Ash Spring Basalt is a 2-m-thick ash-flow tuff, which yielded a ${ }^{40} \mathrm{Ar} /{ }^{39} \mathrm{Ar}$ age of $42.1 \mathrm{Ma}$, indicating that the underlying Ash Spring Basalt is at least $42.1 \mathrm{~m}$.y. old. Above the ashflow tuff is a thick sequence of Chisos tuffs and conglomerates (fig. 3-6). The conglomerates tend to be thicker towards the base of the overlying Mule Ear Spring Tuff. The Mule Ear Spring Tuff is intermittently exposed along the upper flanks of Tule Mountain (fig. 3-6). The uppermost unit at Tule Mountain is the Tule Mountain Trachyandesite dated at approximately $33 \mathrm{Ma}$.

\section{Cerro Castellan}

Cerro Castellan, near Castolon (figs. 3-5 and 3-8A), is another popular geologic outcrop in BBNP. Cerro Castellan includes units of the Chisos Group and Burro Mesa Formation. The base of the Cerro Castellan section includes tuffaceous sedimentary units of the Chisos Group. These rocks are overlain by the Bee Mountain Basalt, which is in turn overlain by undifferentiated Chisos tuffs (Parker, 2002). The Wasp Spring member of the Burro Mesa Formation unconformably overlies Chisos tuffs (fig. 3-9A). The Wasp Spring member is an ignimbrite that yielded a ${ }^{40} \mathrm{Ar} /{ }^{39} \mathrm{Ar}$ date of 29.4 $\mathrm{Ma}$, representing activity before the eruption of the Burro Mesa Rhyolite member, which also yielded a date of 29.4 Ma. At Cerro Castellan, it is possible to see various Wasp Spring flows ranging from non-welded to welded ignimbrite. The Burro Mesa Rhyolite member caps the top of Cerro Castellan. Multiple vents for the Burro Mesa Rhyolite member have been identified in this area. The most spectacular exposures of this 


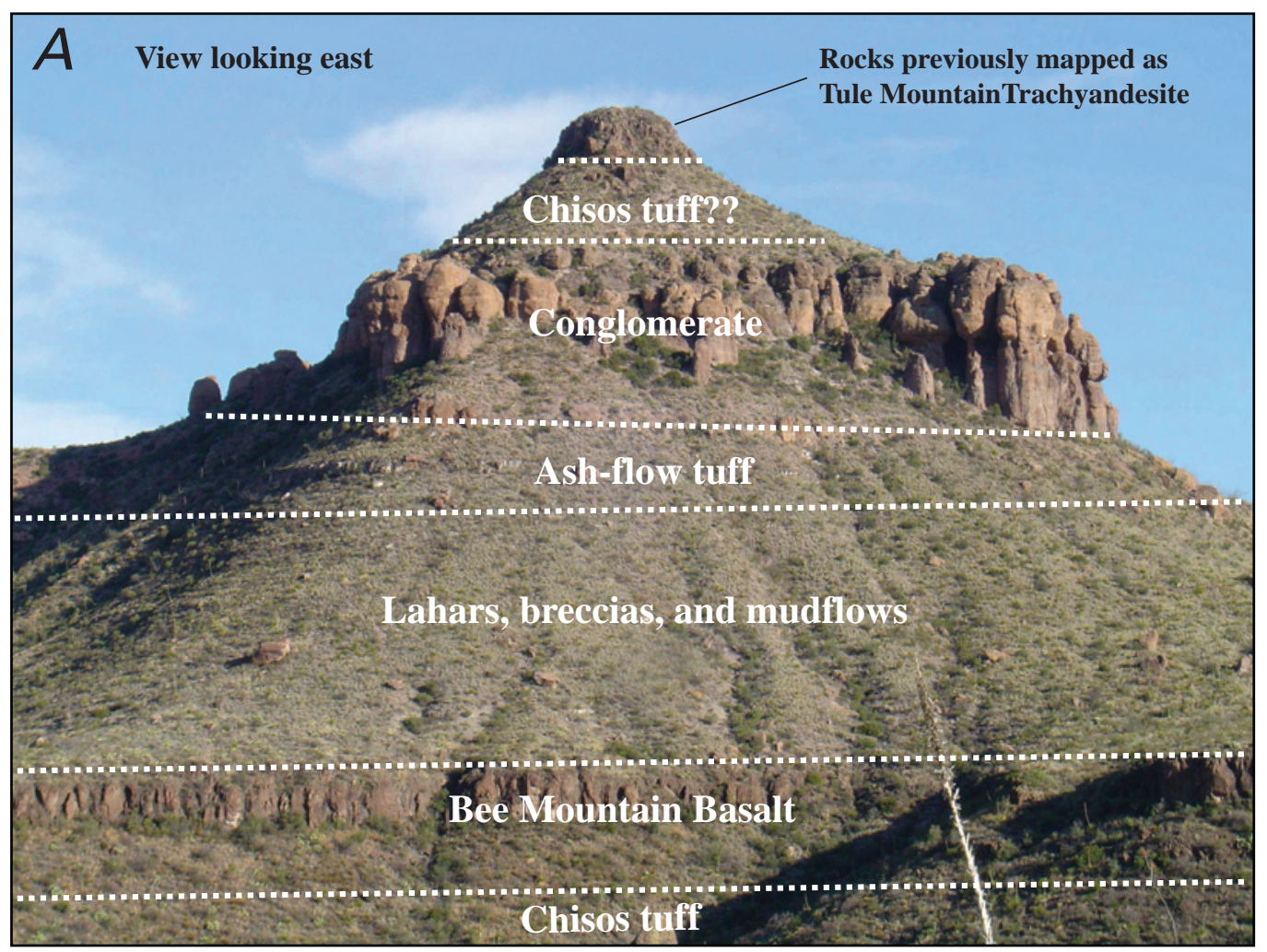

Figure 3-5. Various photos and composite stratigraphic section for the Blue Creek Ranch area. $A$, Photo showing geologic section on the south side of Blue Creek Ranch Overlook. $B$, Photo showing the three distinct ash-flow tuffs on the north side of Blue Creek Ranch. $C$, Photo of rhyolite dike exposed along the Ross Maxwell Scenic Drive. D, Volcanic stratigraphy at Blue Creek Ranch.

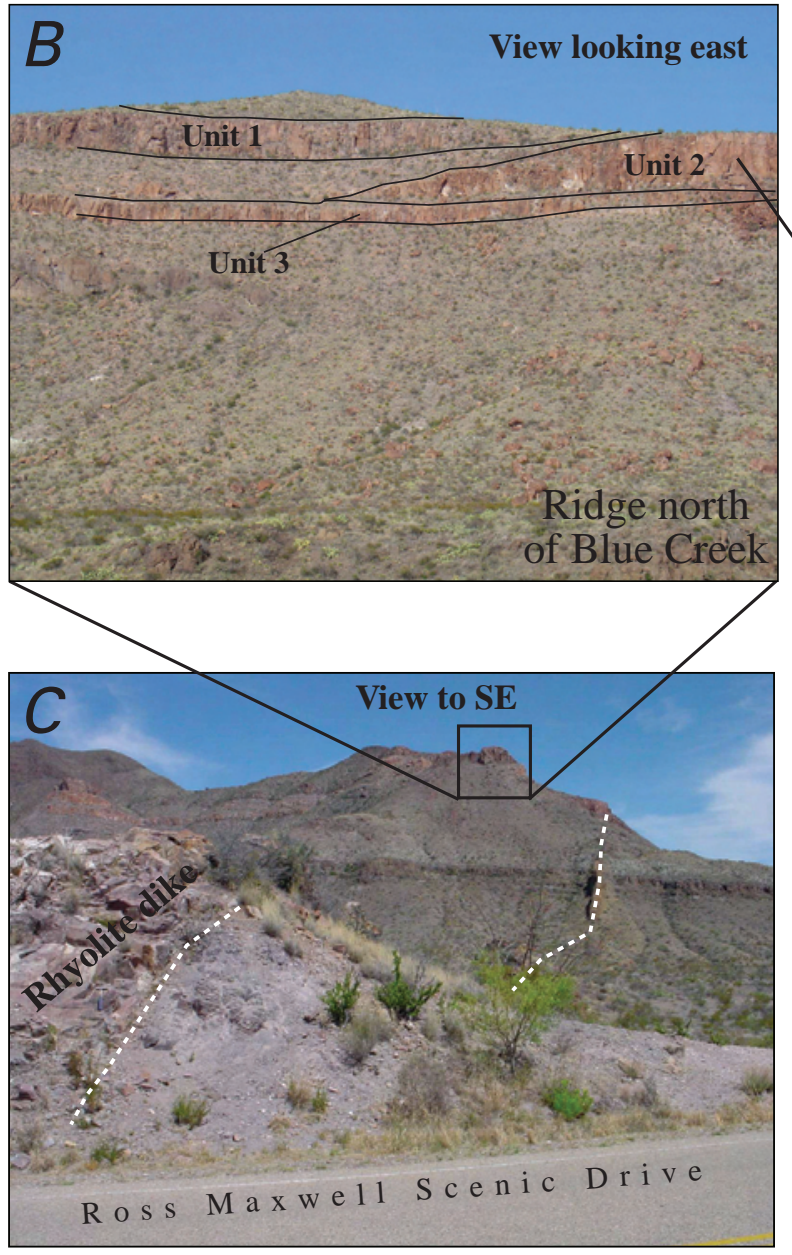

\section{$D$ Blue Creek Ranch composite section} ${ }^{40} \mathrm{Ar} /{ }^{39} \mathrm{Ar}$ Age (Ma)

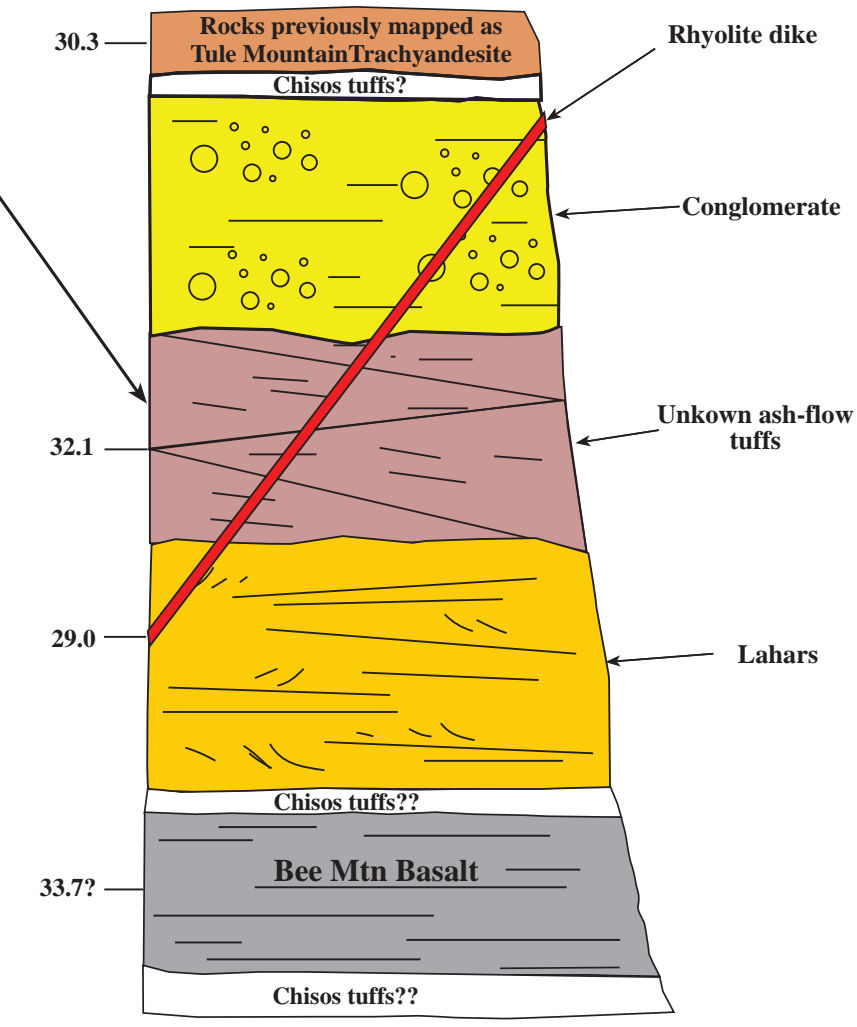




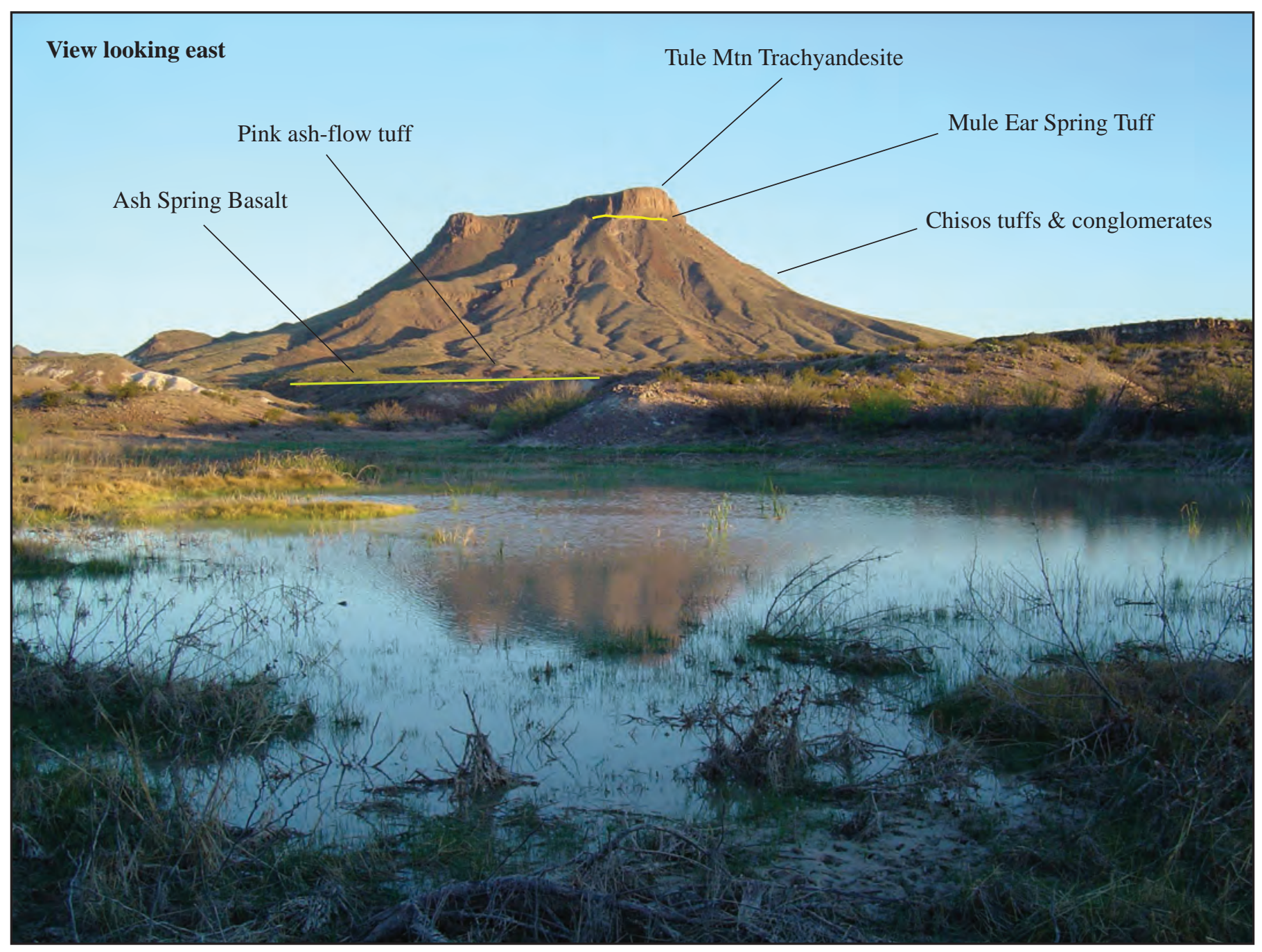

Figure 3-6. Photo of Tule Mountain indicating the major volcanic rocks exposed in the area, which include from base to top: a trachyandesite mapped by Maxwell and others (1967) as the Ash Spring Basalt; a thick section of Chisos Group tuffs, undivided; the Mule Ear Spring Tuff; and the Tule Mountain Trachyandesite.

member are on the north side of Cerro Castellan (fig. 3-8D) where fissures and tubes of the Burro Mesa Rhyolite member are exposed, cutting through Chisos tuffs (fig. 3-9B).

To the south of Cerro Castellan, along Cerro Castellan ridge, are exposures of the Mule Ear Spring Tuff and Bee Mountain lava flows (fig. 3-9A). Basaltic lavas stratigraphically above the Mule Ear Spring Tuff and below the Tule Mountain Trachyandesite were mapped by Maxwell and others (1967) as Tertiary unnamed lavas. Geochemical analyses suggest these lavas correlate with similar lavas described by Henry and Davis (1996) further west as Bee Mountain Basalt flows between the Mule Ear Spring Tuff and Tule Mountain
Trachyandesite (Turner and others, in press). In this respect, Bee Mountain lava flows were interrupted by the Mule Ear Spring Tuff (Henry and Davis, 1996). The Bee Mountain lavas above the Mule Ear Spring Tuff are diagnostic in BBNP because they often contain pea- to boulder-size xenoliths of quartzite up to $1 \mathrm{~m}$ in diameter (fig. 3-9C). These lavas are easily recognized because they are generally plagioclase poor and contain quartzite xenoliths, whereas the Bee Mountain flows below the Mule Ear Spring Tuff have abundant plagioclase. Further dating and geochemical analyses of these rocks are in progress to test the correlation of these rocks with the Bee Mountain Basalt. 


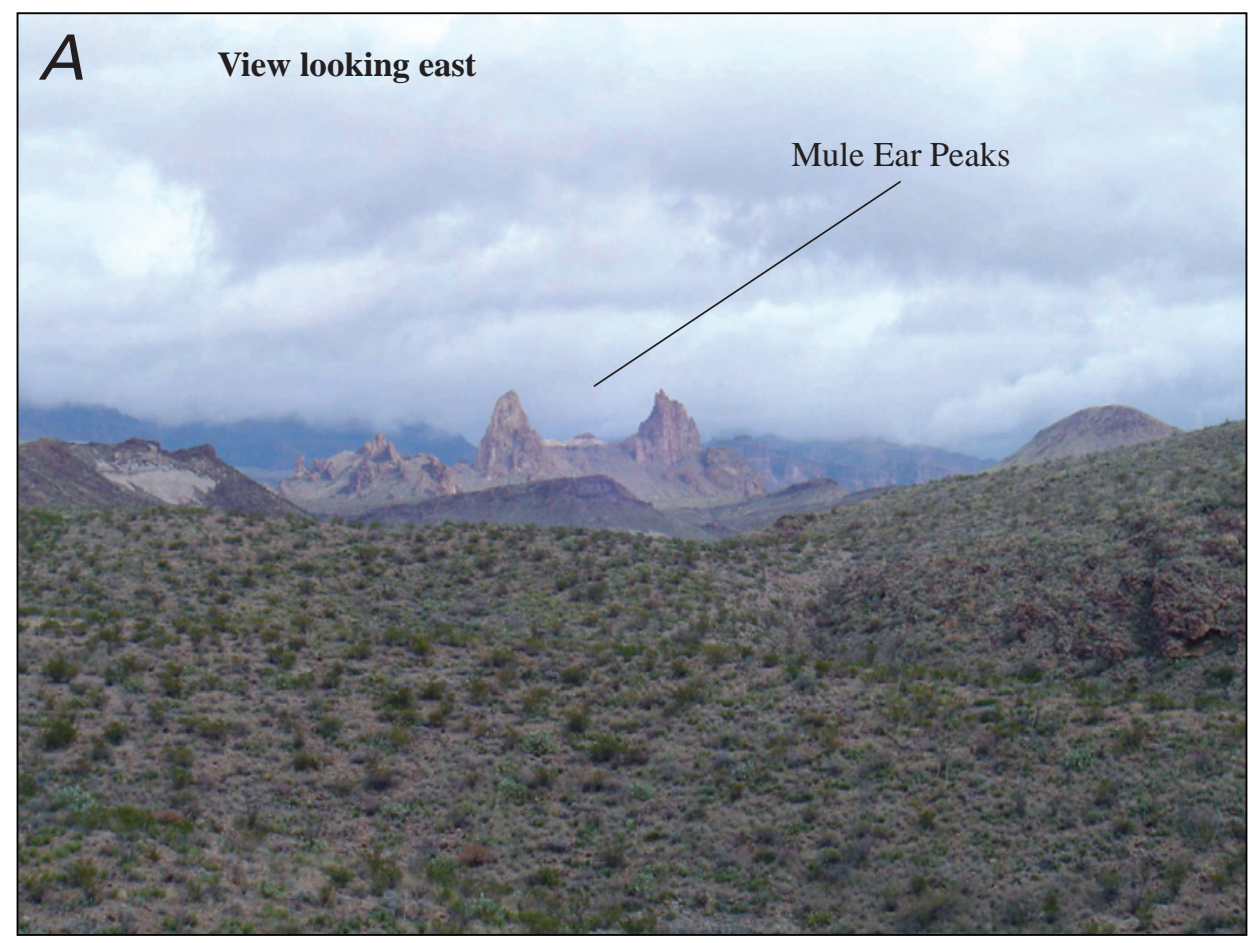

Figure 3-7. Photos showing distant and close up views for the stratigraphy of the Round Mountain area located south of the Mule Ears Viewpoint. $A$, Photo showing Mule Ear Peaks taken from the Mule Ears Viewpoint. $B$, Photo showing the volcanic stratigraphy taken approximately $2 \mathrm{~km}$ south of the Mule Ears Viewpoint. Some of the thickest deposits of the Alamo Creek lavas and Chisos tuff are exposed in this section.

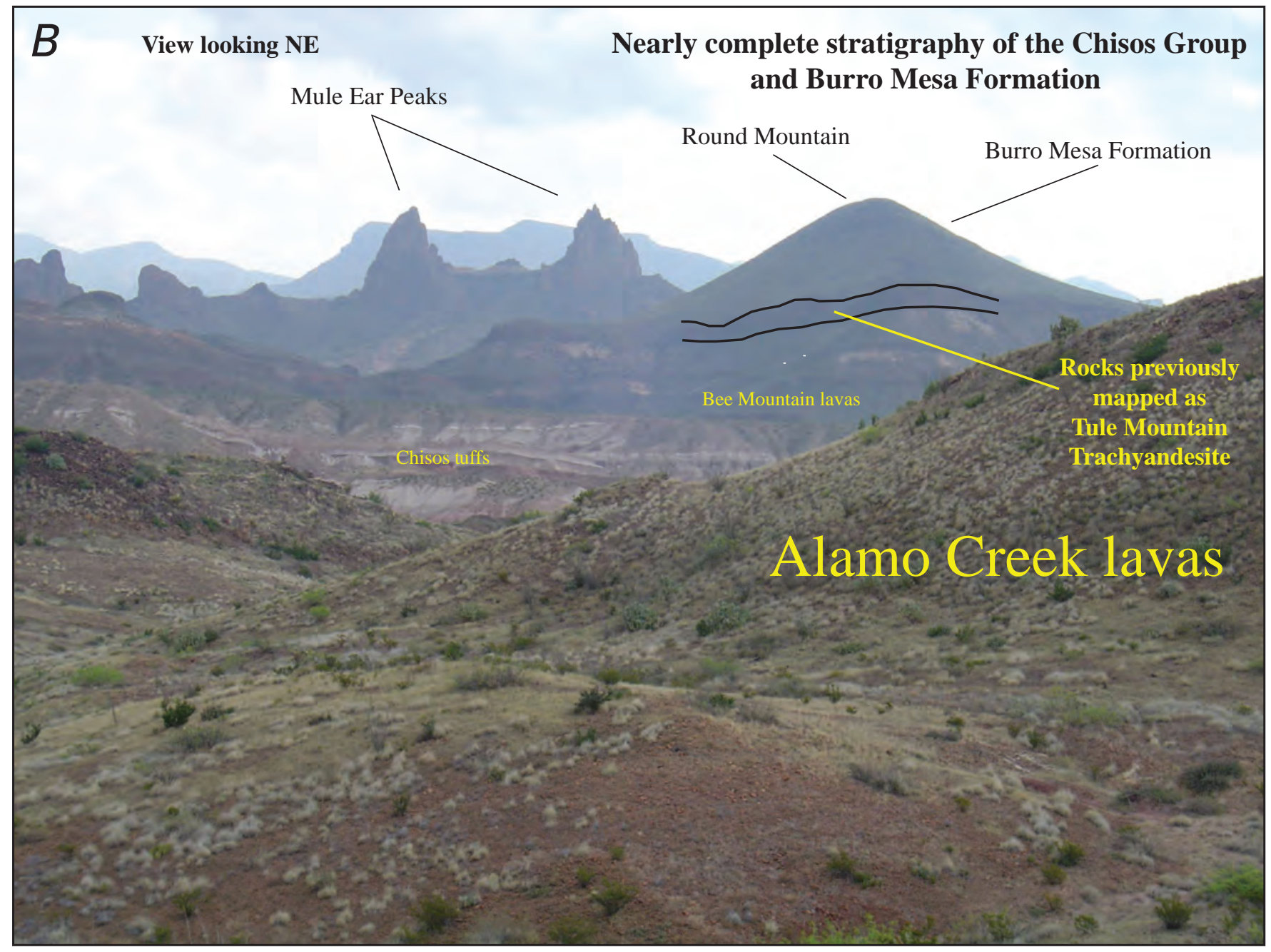




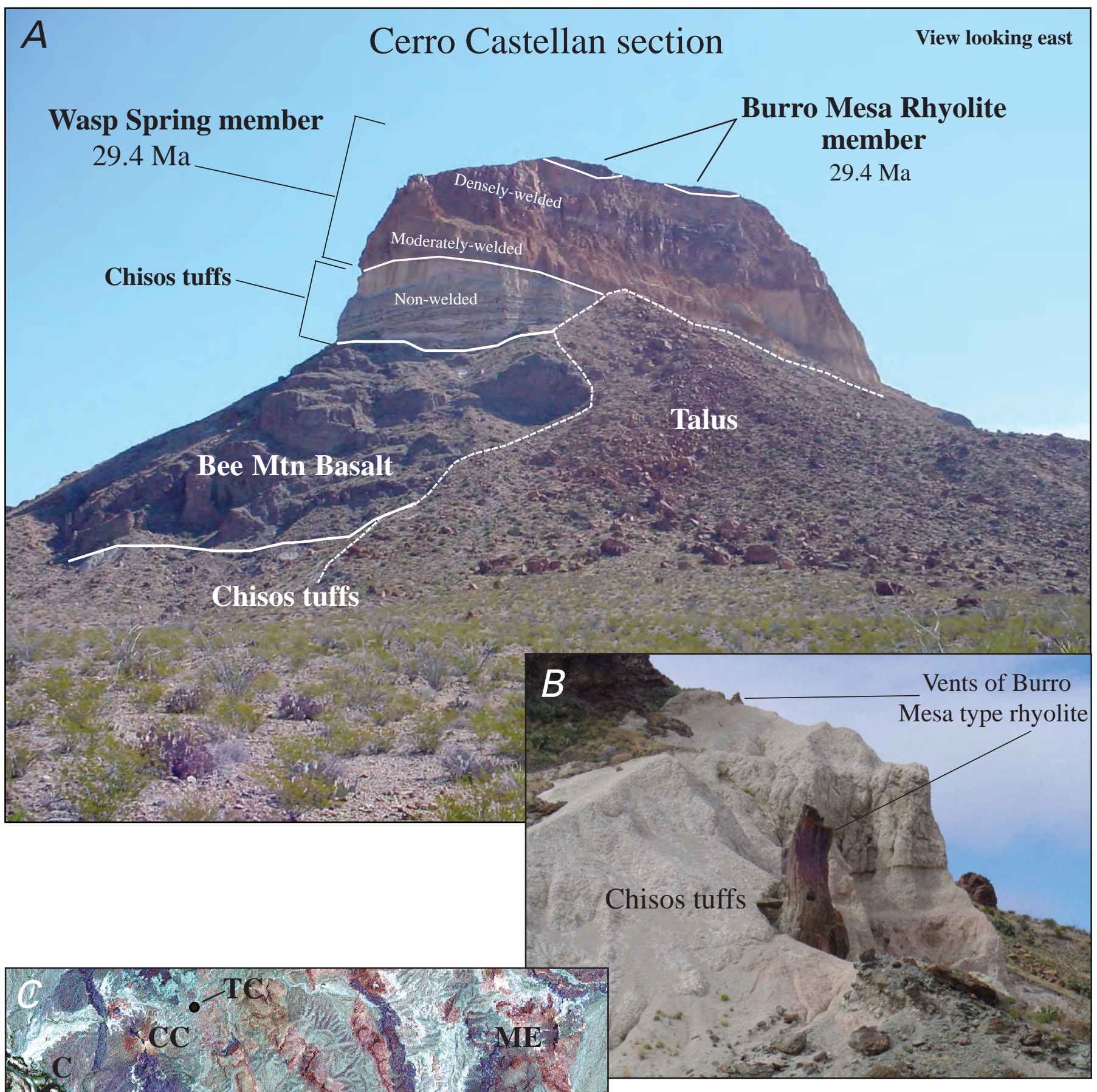

Figure 3-8. Location map and photos showing the stratigraphy of Cerro Castellan. $A$, Photo of Cerro Castellan showing the various volcanic rocks exposed. Outcrops of the Wasp Spring member of the Burro Mesa Formation represent one of the few areas showing the non-welded Chisos tuffs and the moderately-welded and welded nature of the Wasp Spring. $B$, Photo showing several vents of the Burro Mesa Rhyolite exposed in Chisos tuffs. Vents are one of many Burro Mesa vents exposed north of Cerro Castellan. $C$, Landsat 7 image showing some of the major geographic locations around the Cerro Castellan area. ME, Mule Ear Peaks; SCC, Southern Cerro Castellan; C, Castolon; CC, Cerro Castellan; TC, Tuff Canyon. 


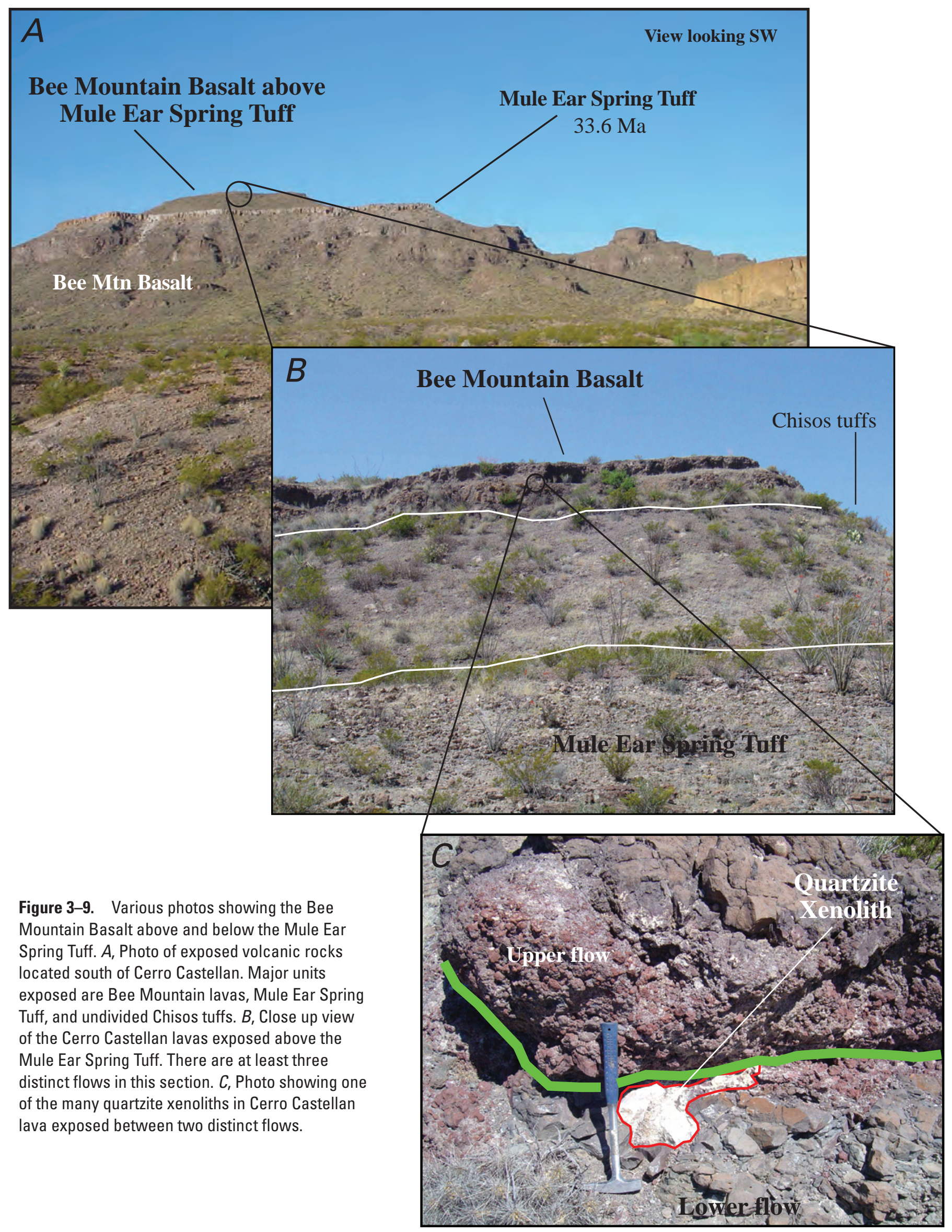




\section{Conclusions}

Big Bend National Park contains a diverse suite of volcanic and plutonic rocks that are exposed primarily along the western half of the park. These volcanic rocks consist of the Chisos Group, and the South Rim and Burro Mesa Formations. Numerous geologic studies on the volcanic rocks within and surrounding BBNP have been conducted in order to determine the timing of these rocks and their formation processes. Understanding the formation of these volcanic rocks is critical in determining how this igneous activity is associated with volcanic rocks throughout the western United States, in particular the Trans-Pecos magmatic province. The park makes up the southeastern portion of this magmatic province, where igneous activity occurred from 46.5 to $17 \mathrm{Ma}$ (Henry and McDowell, 1986).

Ages and geochemical data obtained from numerous rock units have helped to constrain the complex geologic history that has occurred in the western half of BBNP. Based on geological mapping, detailed field sampling and interpretations, geochronology, and geochemistry, we have been able to contribute to a better understanding of some of the most prominent geologic features in the western half of the park, especially lava flows located near the west entrance of BBNP.

\section{Acknowledgments}

We wish to thank William R. Page, Kenzie Turner, and John E. Gray for their detailed reviews that greatly improved the organization and clarity of this report. We thank Ross Yeoman and Rae Ann Orkild for helping with the argon analyses and Jim Budahn for the geochemical analyses. We also thank Rae Ann Orkild, Nathan Thompson, and Kay Wache for their invaluable help with the mineral separations and Paul Wigton and Kay Wache for their help in the field by assisting with the collection of many needed rock samples over several kilometers of rugged landscape. Without their help this study would not be possible. We thank Big Bend National Park for allowing us to conduct this work over the years.

\section{References Cited}

Barker, D.S., 1977, Northern Trans-Pecos magmatic provinceIntroduction and comparison with the Kenya rift: Geological Society of America Bulletin, v. 88, p. 1,421-1,427.

Barker, D.S., 1987, Tertiary alkaline magmatism in Trans-Pecos Texas: Geological Society of London Special Publication, v. 30, p. 415-431.

Barker, D.S., Henry, C.D., and McDowell, F.W., 1986, Pine Canyon caldera, Big Bend National Park-A mildly peralkaline magmatic system, in Price, J.G., Henry, C.D., Parker, D.F., and Barker, D.S., eds., Igneous geology of Trans-Pecos Texas-Field trip guide and research articles: University of Texas at Austin, Bureau of Economic Geology Guidebook 23, p. 266-285.

Benker, S.C., 2005, The petrology of the South Rim Formation, Big Bend National Park, Texas: Richmond, Ky., Eastern Kentucky University, M.S. thesis, 104 p.

Carman, M.F., Stewart, R.M., Jr., and Casey, J.F., 2003, Characterization of the Alamo Creek Basalt, Big Bend National Park, Texas: Texas Journal of Science, v. 55, no. 2, p. 99-128.

Drenth, B.J., 2005, Interpretation of geophysical anomalies over the Pine Canyon Caldera, Big Bend National Park, Texas: El Paso, Tex., University of Texas at El Paso, M.S. thesis, $78 \mathrm{p}$.

Henry, C.D., and Davis, L.L., 1996, Tertiary volcanic, volcaniclastic, and intrusive rocks adjacent to the Solitario, in Henry, C.D., and Muehlberger, W.R., eds., Geology of the Solitario Dome, Trans-Pecos Texas-Paleozoic, Mesozoic, and Cenozoic sedimentation, tectonism, and magmatism: University of Texas at Austin, Bureau of Economic Geology Reports of Investigations 240, p. 81-108.

Henry, C.D., Davis, L.L., Kunk, M.J. and McIntosh, W.C., 1998, Tertiary volcanism of the Bofecillos Mountains and Big Bend Ranch State Park-Revised stratigraphy and ${ }^{40} \mathrm{Ar} /{ }^{\beta 9} \mathrm{Ar}$ geochronology: University of Texas at Austin, Bureau of Economic Geology Report of Investigations 253, $76 \mathrm{p}$.

Henry, C.D., and McDowell, F.W., 1986, Geochronology and magmatism in the Tertiary volcanic field, TransPecos Texas, in Price, J.G., Henry, C.D., Parker, D.F., and Barker, D.S., eds., Igneous geology of Trans-Pecos Texas-Field trip guide and research articles: University of Texas at Austin, Bureau of Economic Geology Guidebook 23, p. 99-122.

Henry, C.D., and Price, J.G., 1984, Variations in caldera development in the Tertiary volcanic field of Trans-Pecos Texas: Journal of Geophysical Research, v. 89, no. B10, p. $8,765-8,786$. 
Henry, C.D., Price, J.G., and James, E.W., 1991, Mid-Cenozoic stress evolution and magmatism in the southern Cordillera, Texas and Mexico-Transition from continental arc to intraplate extension: Journal of Geophysical Research, v. 96, no. B8, p. 13,545-13,560.

Laughlin, A.W., Kress, V.C., and Aldrich, M.J., 1982, K-Ar ages of dike rocks, Big Bend National Park, Texas: Isochron West, v. 35, p. 17-18.

LeBas, M.J., LeMaitre, R.W., Streckeisen, A., and Zanettin, B., 1986, A chemical classification of volcanic rocks based on the total alkali silica diagram: Journal of Petrology, v. 27, p. 745-750.

Maxwell, R.A., Lonsdale, J.T., Hazzard, R.T., and Wilson, J.A., 1967, Geology of Big Bend National Park, Brewster County, Texas: University of Texas at Austin, Bureau of Economic Geology Publication 6711, 320 p.

Miggins, D.P., Ren, M., Anthony, E., Iriondo, A., and Wooden, J.L., 2006, New constraints on the timing of volcanism and associated intrusive rocks in Big Bend National Park using ${ }^{40} \mathrm{Ar} /{ }^{39} \mathrm{Ar}$ and U-Pb geochronology [abs.]: Geological Society of America Abstracts with Programs, v. 38, no. 7, p. 156.

Miggins, D., Scott, R.B., Snee, L.W., 2004, New ${ }^{40} \mathrm{Ar} /{ }^{39} \mathrm{Ar}$ ages from Big Bend National Park [abs.]: Geological Society of America Abstracts with Programs, v. 36, no. 5, p. 128.

Parker, D.F., 2002, Horseshoe Canyon volcanic dome, in White, J.C., ed., The Geology of Big Bend National Park: What Have We Learned Since Maxwell and others (1967)?: Geological Society of America South-Central meeting, Alpine, Tex., Field trip guide, p. 24-32.

Turner, K.J., Budahn, J.R., and Miggins, D.P., in press, A reinterpretation of some correlations of Chisos Group mafic lavas with new geochemistry and geochronology, Big Bend National Park, Texas [abs.]: Geological Society of America Abstracts with Programs.

White, J.C., Benker, C.S., Ren, M., Urbanczyk, K.M., and Corrick, D.W., 2006, Petrogenesis and tectonic setting of the peralkaline Pine Canyon caldera, Trans-Pecos Texas, USA: Lithos, v. 91, p. 74-94. 


\title{
4. Where Magma Meets Limestone: Dagger Flats, an Example of Skarn Deposits in Big Bend National Park
}

\author{
By Lisa A. Morgan and W.C. Pat Shanks III
}

\section{Abstract}

Igneous rocks of Big Bend National Park make up greater than half of all rock types in the park. An igneous style dominant in the northeastern part of the park is manifest by a series of intrusive units forming tabular bodies that were emplaced into the Earth's upper crust as sills. At Dagger Flats, the intrusion of predominantly alkaline mafic magmas as sills into the Cretaceous Boquillas Formation, a sequence of near-shore marine carbonate units, resulted in the formation of skarn deposits. These deposits have formed by contact metamorphism resulting from intrusion of hot magma into the upper crust. Reaction with host limestone units forms an assemblage of alteration minerals that include calcsilicates such as wollastonite, grossular garnet, prehnite, and zeolites, as well as clays and recrystalized calcite and quartz. At Dagger Flats, detailed sampling through several stratigraphic sections from the sill upward through the top of the capping skarn indicates that the porosity and permeability of various carbonate rocks within the Boquillas Formation controlled hydrothermal fluid infiltration where skarn-forming reactions influenced the distribution of mineralized rock.

\section{Introduction}

The igneous landscape dominating much of Big Bend National Park (BBNP) includes, but is not limited to, tectonically controlled dike and sill systems, shallow intrusive bodies, lava flows, and large ignimbrite-producing calderas. These igneous forms have been variably influenced or controlled by regional tectonism (Henry and Price, 1984). Many are associated with fossil hydrothermal systems that altered and mineralized the surrounding host rocks to varying degrees. One example of the interaction among magma, host rock, and hydrothermal mineralizing fluids can be found at Dagger Flats in the northeast corner of BBNP (fig. 4-1A). Lower Oligocene mafic and subordinate felsic sills intruded Cretaceous limestone rocks and produced skarn deposits. The focus of this paper is to describe one of several igneous landscapes in
BBNP and document this type of environment where skarn deposits are associated with shallow intrusions.

Skarn deposits are characterized by calc-silicate minerals in limestone or limestone-bearing rocks that have formed by contact metamorphism resulting from the intrusion of hot magma into cooler country rock. At the contact between the intrusive body and the host rock, heat, circulating hydrothermal fluids, and magmatic gases interact and react with the limestone host to form minerals such as wollastonite, $\mathrm{CaSiO}_{3}$, and diopside, $\mathrm{CaMg}\left(\mathrm{Si}_{2} \mathrm{O}_{6}\right)$. The composition and physical characteristics of the intrusive body, in addition to the physical and chemical nature of the carbonate host, control the mineralogy of skarn deposits (Lentz, 1998). In turn, the porosity and permeability in the varying depositional near-shore environments of the carbonate rocks control hydrothermal fluid infiltration where the skarn formed.

\section{Dagger Flats}

The Dagger Flats area is found along the southwestern base of the Sierra del Carmen, a series of long, northwesttrending ridges composed of massive Lower Cretaceous limestone (fig. 4-1A) (Maxwell, 1968). The landscape of Dagger Flats is represented by a series of low northwest-trending fault-bounded hills (fig. 4-1) cored with thick sills (tabular, conformable igneous bodies) that intruded into the Cretaceous Boquillas Formation (fig. 4-2A). Skarn deposits are exposed in the capping carbonate strata directly above the sills.

\section{Sills}

At Dagger Flats, sills are exposed as broad resistant ledges (fig. 4-1C) conformably capped by relatively thin (up to 20-25 m thick) erosional remnants of a sequence of carbonaceous marls, clays, mudstones, and siltstones of the Cretaceous Boquillas Formation. The sills are composite bodies with exposures 10 to $30 \mathrm{~m}$ thick that gently dip approx. 5-10 S-SW. 


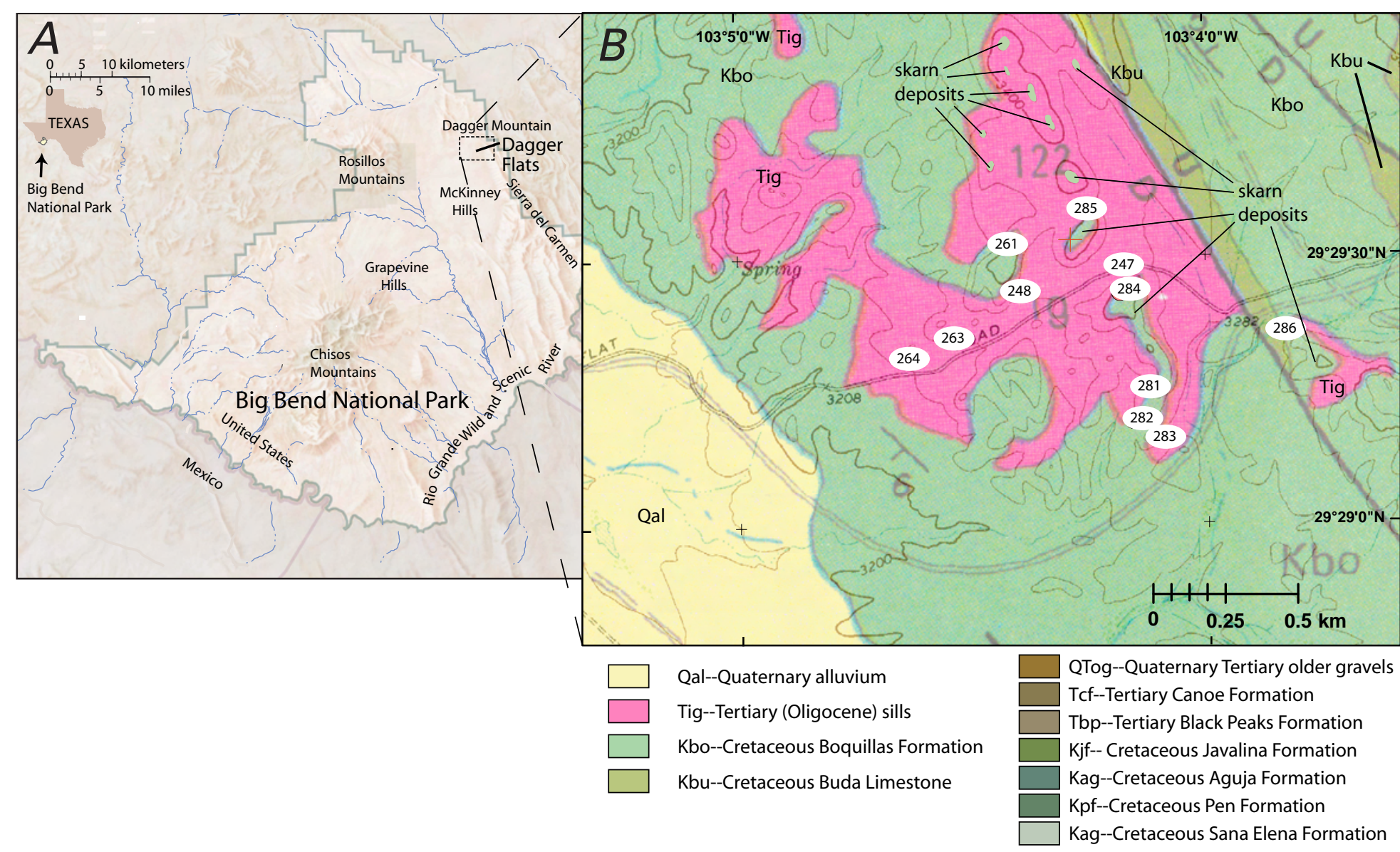

Figure 4-1. Index maps and photo of study are

in Big Bend National

Park and at Dagger

Flats. A, Location of Big Bend National Park in southwest Texas;

Dagger Flats is in the northeast part of the park. Inset shows where Big Bend National Park is located in Texas. $B$, Generalized, slightly modified, geologic map from Maxwell (1968) showing sampling site locations (site numbers correspond to sampling locations in white ovals). This area is cut by predominantly northwest-trending faults; downthrown side is indicated by letter $D$. Mapped skarn deposits are in the Cretaceous Boquillas Formation above the sills at Dagger Flats, mapped in pink as Tig. C, View of the lowlying, fault-bounded hills cored by Tertiary sills at Dagger Flats. Skarns in the Cretaceous

Boquillas Formation cap the hills, which are 20 to $40 \mathrm{~m}$ high. 

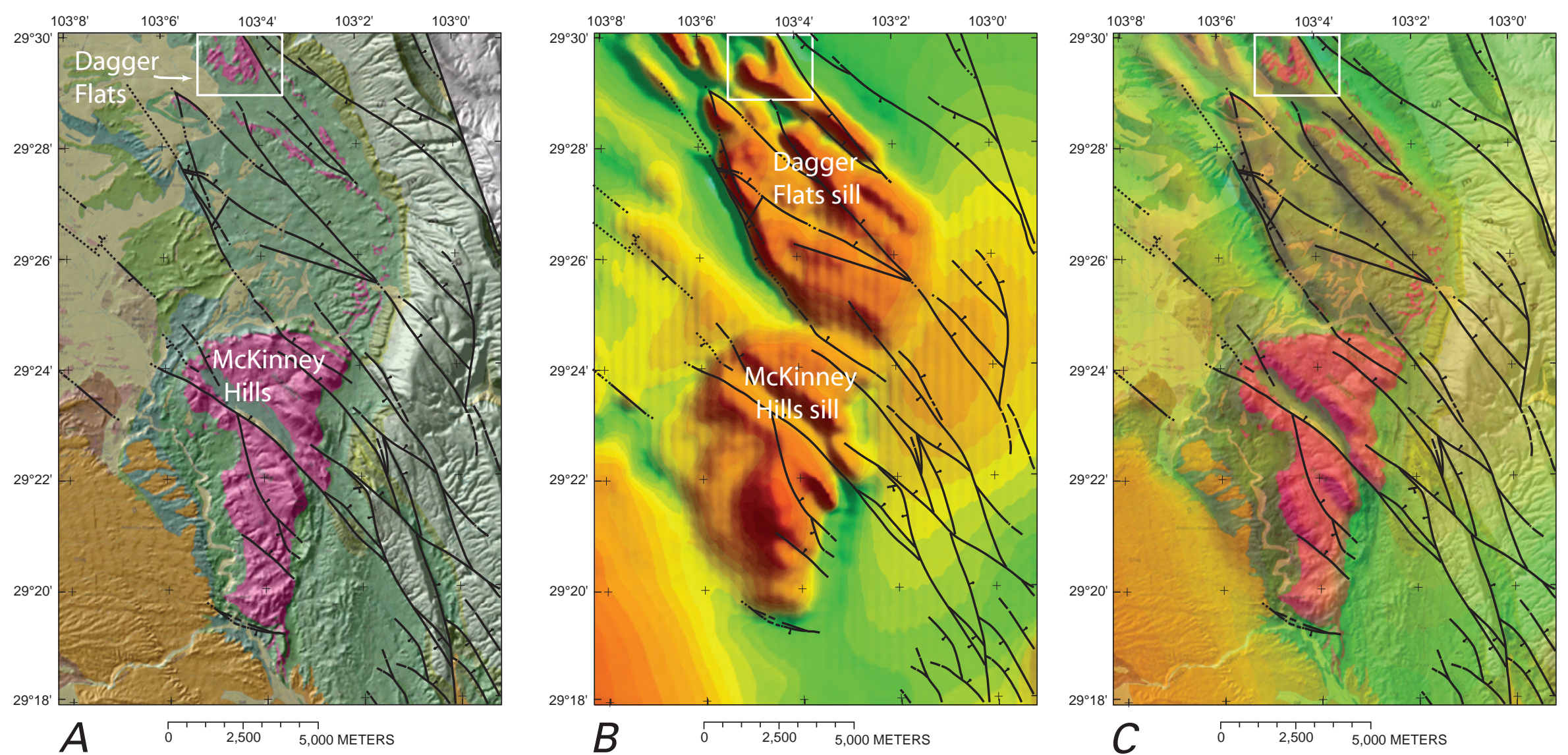

Figure 4-2. Maps of the Dagger Flats vicinity. $A$, Geologic map (from Maxwell, 1968) of Dagger Flats (shown in white outline) and McKinney Hills to the south draped over gray shaded-relief topographic map. Units are the same as shown in figure 4-1B. B, High-resolution, reduced-to-pole magnetic intensity map of same area shown in figure 4-2A (C.A. Finn, written commun., 2004). Magnetic intensities range from $1060 \mathrm{nT}$ to $930 \mathrm{nT}$; higher values are shown in warm colors and lower values are in cooler colors. In comparing the limited extent of the Tertiary sills exposed at Dagger Flats as shown on the geologic map in figure 4-2A with the extent of the large positive magnetic intensities in this map, the body associated with the sills at Dagger Flats has a much larger extent than the exposed sills. Faults from the geologic map have been draped on the magnetic intensity map and correspond well with breaks in intensity values in the large sill body, measured at approx. $5 \mathrm{~km}$ northeast by 12-22 km northwest. Other similar bodies with cross-cutting faults can be seen to the south at McKinney Hills, where the exposure of sills is prominent (seen here) and to the west in the Rosillos Mountains. C, Composite diagram showing the strong correlation between the geologic map of Dagger Flats and McKinney Hills and the reduced-to-pole magnetic intensity map. The geologic map is draped over a gray shaded-relief topographic map (fig. 4-2A), which, in turn, is draped by the magnetic intensity map (fig. 4-2B). 
High-resolution aeromagnetic mapping in BBNP (C.A. Finn, written commun., 2004; Anderson and others, 2004) shows that the Dagger Flats area is underlain by a positive magnetic anomaly that is roughly oval-shaped in plan view and has a larger extent than the area commonly known as Dagger Flats (fig. 4-2B). The oval body, interpreted as a shallow-level sill, has moderate positive values of magnetic intensity and is a northwest-striking structure about 15 to 22 $\mathrm{km}$ long and about $5 \mathrm{~km}$ wide. The Dagger Flats sill is of comparable size to or larger than adjacent sills and intrusive bodies, including those in the McKinney Hills (fig. 4-2B) and, to the west, in the Rosillos Mountains and Grapevine Hills (fig. 4-1A). Assuming a typical maximum thickness of $100 \mathrm{~m}$ documented seismically for many sills (Chevalier and Woodford, 1999; Smallwood and Maresh, 2002; Thomson, 2004; Thomson and Hutton, 2004), the sills at Dagger Flats give an estimated maximum volume of the sill body at approximately $11 \mathrm{~km}^{3}$. If we assume a thinner body of $30 \mathrm{~m}$ (which we see exposed at the surface), the minimum estimated volume for the Dagger Flats sill would be about $3.3 \mathrm{~km}^{3}$, about eight times the volume of total erupted magma in the multiple eruptions during 1980 at Mount Saint Helens, Wash.

The majority of the sills at Dagger Flats are a series of dark brown, coarse-grained, pyroxene-plagioclase-bearing silica-undersaturated alkaline intrusive rocks, referred to as alkali gabbros; silica content ranges from 41 to $44 \mathrm{wt}$ \% (weight percent) (fig. 4-3B). Sill lenses are 3 to $10 \mathrm{~m}$ thick, vertically jointed, and weather as large spheroidal blocks. Individual pyroxene phenocrysts, up to $7 \mathrm{~cm}$ in length, reflect a relatively long cooling period for the intrusions and indicate emplacement at some depth where the surrounding rocks are warmer due to temperature increase along the geothermal gradient of the earth.

In various exposures at Dagger Flats, a few smaller $(<1$ $\mathrm{m}$ thick) monzonite sills intrude the coarser alkali gabbroic sill sequence (fig. 4-3) and are common features in at least 10 sill and laccolith localities in the Big Bend area (Carman, 1994). The monzonite sills have sharp contacts with the main mafic body and are light gray, fine- to medium-grained, subhorizontal thin sheets rich in alkali feldspar and plagioclase. Chemically, these rocks plot in the monzonite field on the TAS (Total Alkali Silica) diagram (fig. 4-3B) (Middlemost, 1994). Silica content for these later-intruded sills ranges between 52 to 56 wt. $\% \mathrm{SiO}_{2}$; total water for the monzonite sills range from 3.1 to 4.4 wt. $\%$. Along the contact with the alkali gabbroic sill, thermal cracks perpendicular to the orientation of the monzonite sill sheet (fig. 4-3C) indicate that it intruded into the cooled mafic sill and was quenched. The thickness of the monzonite is somewhat variable and ranges from a few centimeters to about $1 \mathrm{~m}$ thick. A high-precision ${ }^{40} \mathrm{Ar} /{ }^{39} \mathrm{Ar}$ radiometric analysis of fine-grained groundmass from the monzonite (BB-05-248.1) yields a date of 32.47 $\pm 0.41 \mathrm{Ma}$.

\section{Hydrothermal Alteration of the Sills}

Hydrothermal alteration is present in both the alkali gabbroic sill and to a greater extent in the monzonite sill, based on alteration mineralogy and oxygen isotope values. Alteration mineralogy associated with the alkali gabbroic sill is primarily zeolitic (analcime, thomsonite, tetranatrolite) with clinochlore, phlogopite, and kaolinite (fig. 4-4). Analcime, kaolinite, montmorillonite, and chlorite were identified as alteration minerals associated with the smaller monzonitic sill.

Samples from the alkali gabbro sill have whole rock oxygen isotope values $\left(\delta^{18} \mathrm{O}_{\mathrm{wr}}\right)$ of 6.9 to 10.1. Most $\delta^{18} \mathrm{O}_{\mathrm{wr}}$ values for unaltered igneous rocks range between 6 and 8 . One coarse-grained alkali gabbro sill sample yields a $\delta^{18} \mathrm{O}_{\mathrm{wr}}$ value of 6.9; however, three other alkali gabbro sill samples yield $\delta^{18} \mathrm{O}_{\mathrm{wr}}$ values ranging from 9.6 to 10.3. Samples from the volumetrically subordinate monzonite sills have higher $\delta^{18} \mathrm{O}_{\mathrm{wr}}$ values ranging from 12.6 to 13.1 , indicating that hydrothermal alteration was more prevalent in these sills than the alkali gabbro host sill. The oxygen isotopic values and silicate mineralogy of the altered sills indicate late-stage lower temperature alteration, especially in late monzonite intrusions. These inferences, based on oxygen isotopes, are consistent with the stability range for some zeolite minerals, which is about $150-250^{\circ} \mathrm{C}$ (Bird and others, 1984).

Figure 4-3 (facing page). Series of photographs of composite sills exposed in the Dagger Flats area and their range in composition. $A$, Exposure showing a composite sill exposed in hillside at Dagger Flats flanked below and above by the Boquillas Formation. Thin $(<1 \mathrm{~m})$, light-colored, monzonite sill is exposed between thicker ( $>5 \mathrm{~m}$ ) and darker alkali gabbroic sills. Skarn is capping hill. $B$, Total Alkali Silica (TAS) diagram showing the compositions of the dominant alkali gabbroic sill and volumetrically minor monzonite sill (from Middlemost, 1994). C, View of monzonite sill intruded into the alkali gabbroic sill showing chilled margins of the smaller monzonite sill. Thickness of monzonite sill is approx. $60 \mathrm{~cm}$. $D$, Photograph of composite sill. Lighter gray unit is the monzonite sill; thickness here is approx. $4 \mathrm{~cm}$. 


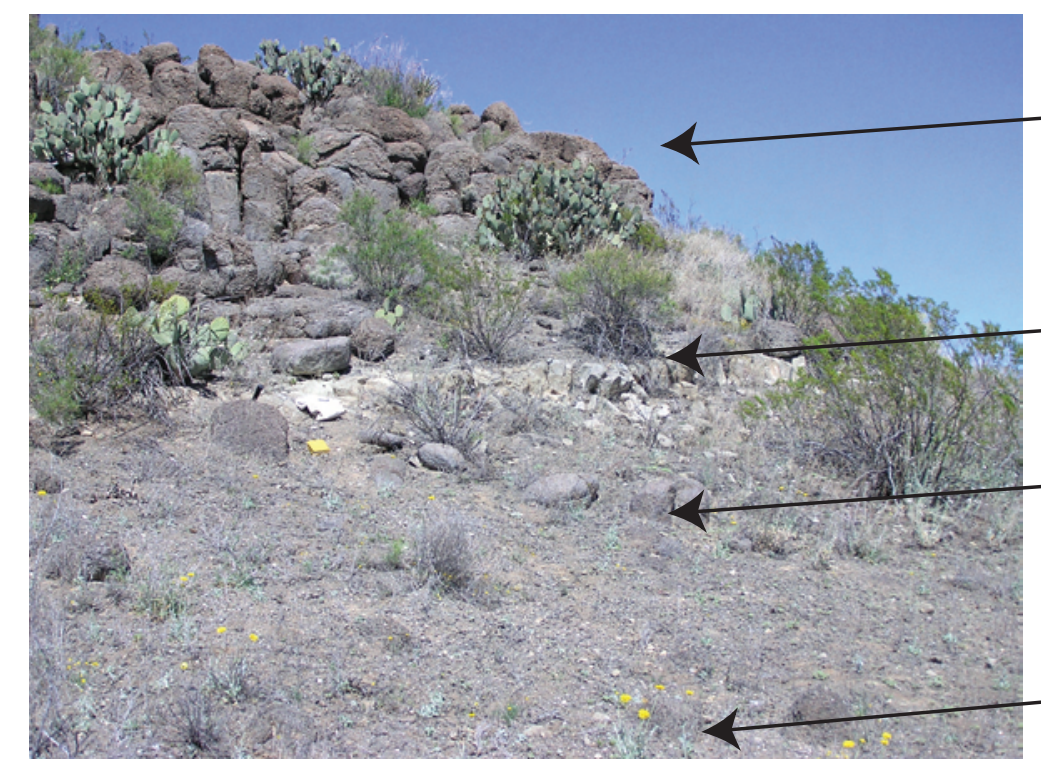

A alkali gabbro sill

monzonite sill

alkali gabbro sill

Boquillas Formation (covered)
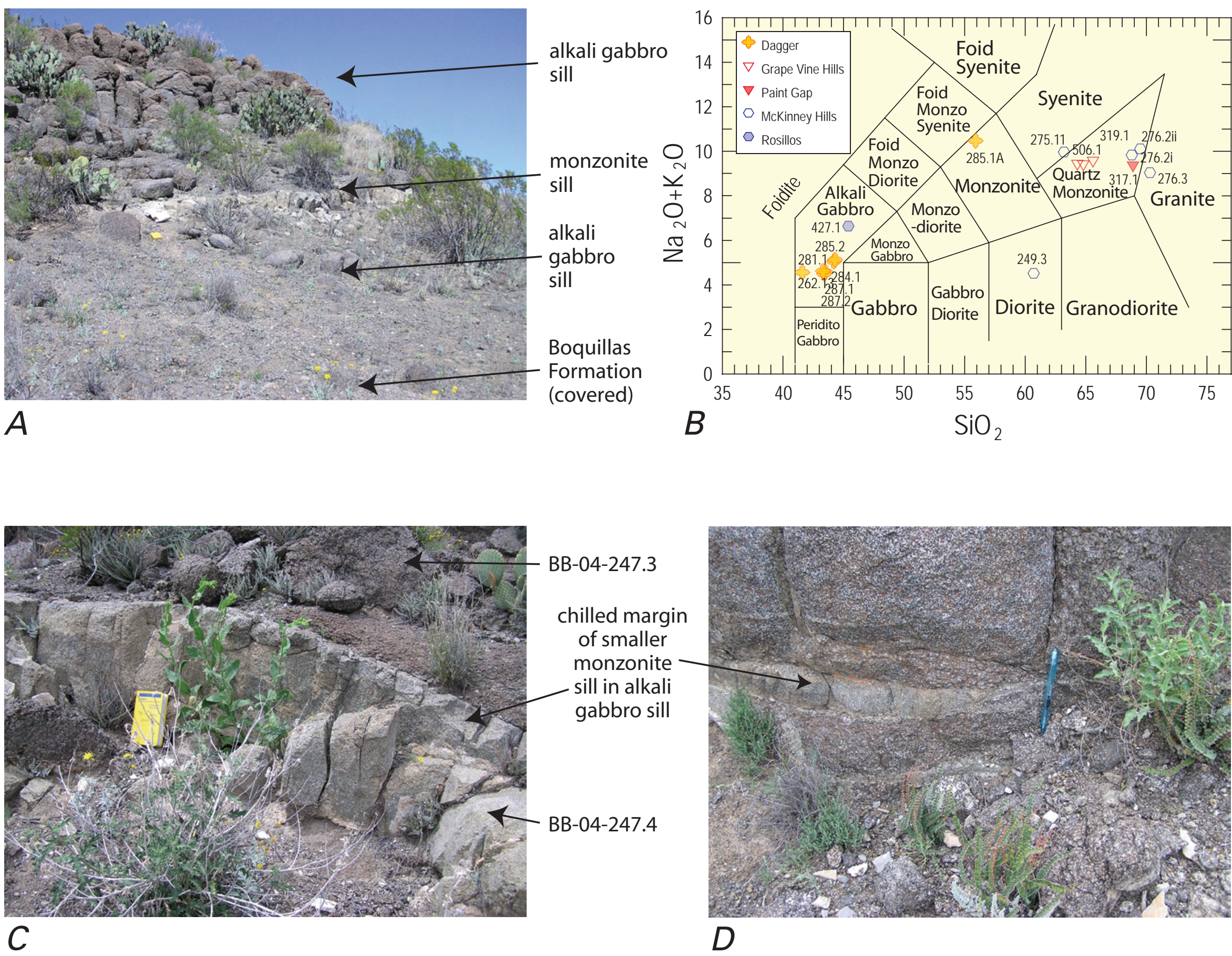

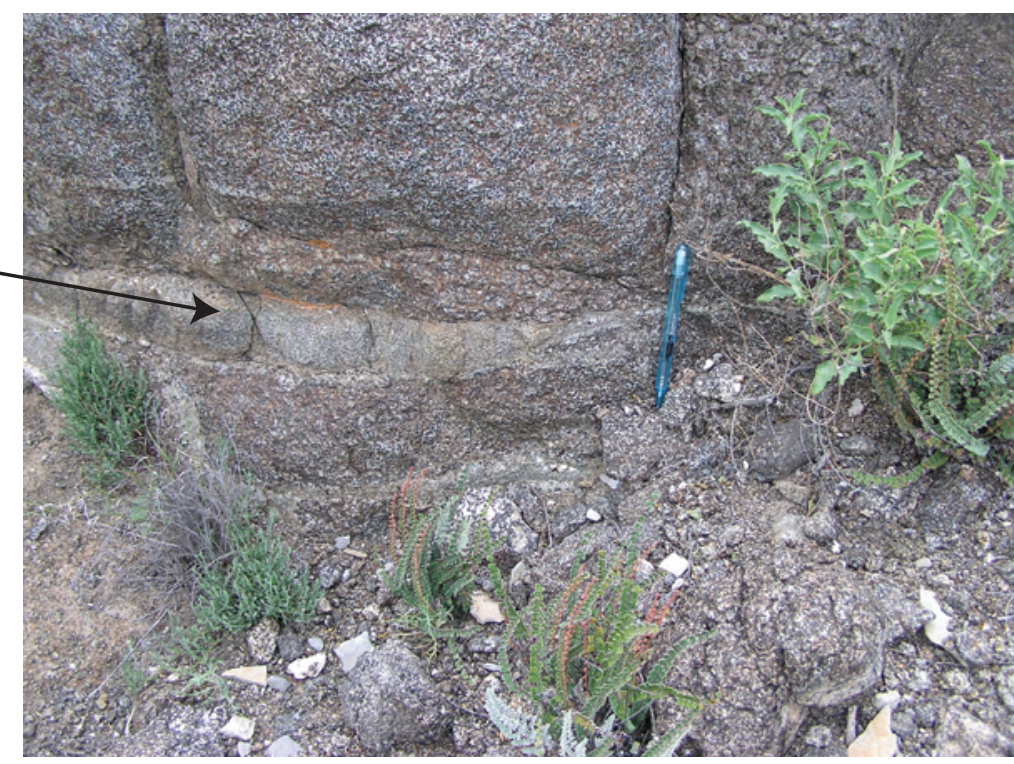

D 
site 286 (at edge)

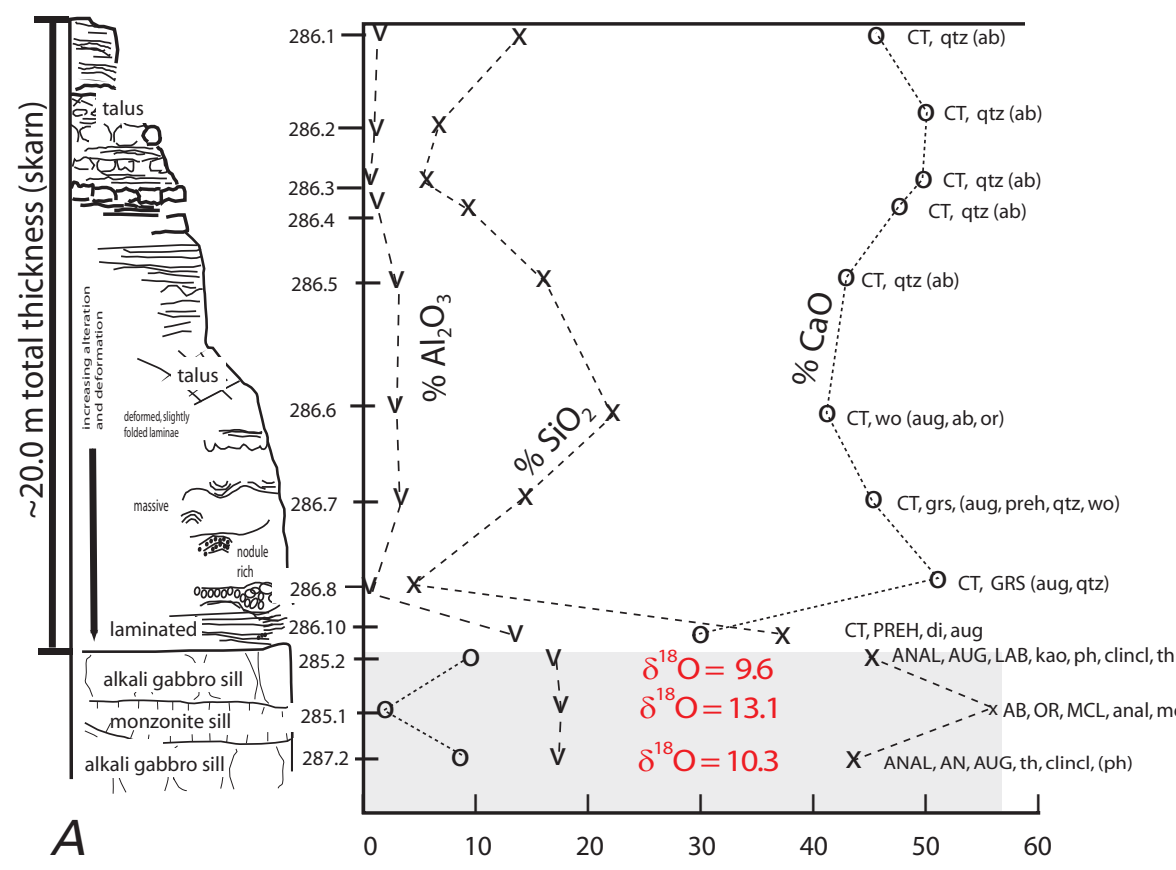

Figure 4-4 (left and facing page). Four diagrams from various sites at Dagger Flats where schematic stratigraphic sections are compared with variation in content of $\mathrm{SiO}_{2}$ (marked by $\mathrm{X}$ ), $\mathrm{CaO}$ (marked by 0 ), and $\mathrm{Al}_{2} \mathrm{O}_{3}$ (marked by $\mathrm{V}$ ) and with changes in depth in the capping mineralized limestone units above the sill. Also compared are alteration mineralogies for the skarn and sills. Values in $\delta^{18} 0$, shown in red, are for samples collected from the sills. Minerals identified and represented in these stratigraphic sections include: CT (calcite), OTZ (quartz), AB (albite), OR (orthoclase), AUG (augite), WO (wollastonite), GRS (grossular garnet), PREH (prehnite), DI (diopside), ANAL (analcime), LAB (labrodorite), KAO (kaolinite), ph (phlogopite), MCL (microcline), mont (montmorillonite), clincl (clinochlore), th (thomsonite), musc (muscovite), AN (anorthite), vermic (vermiculite), sm (smectite), andr (anhydrite), and chl (chlorite). Major minerals are those in upper case letters, minor minerals are in lower case letters; trace minerals are in lower case letters in parentheses. $A$, Site 286 (fig. 4-1B) showing characteristics of the

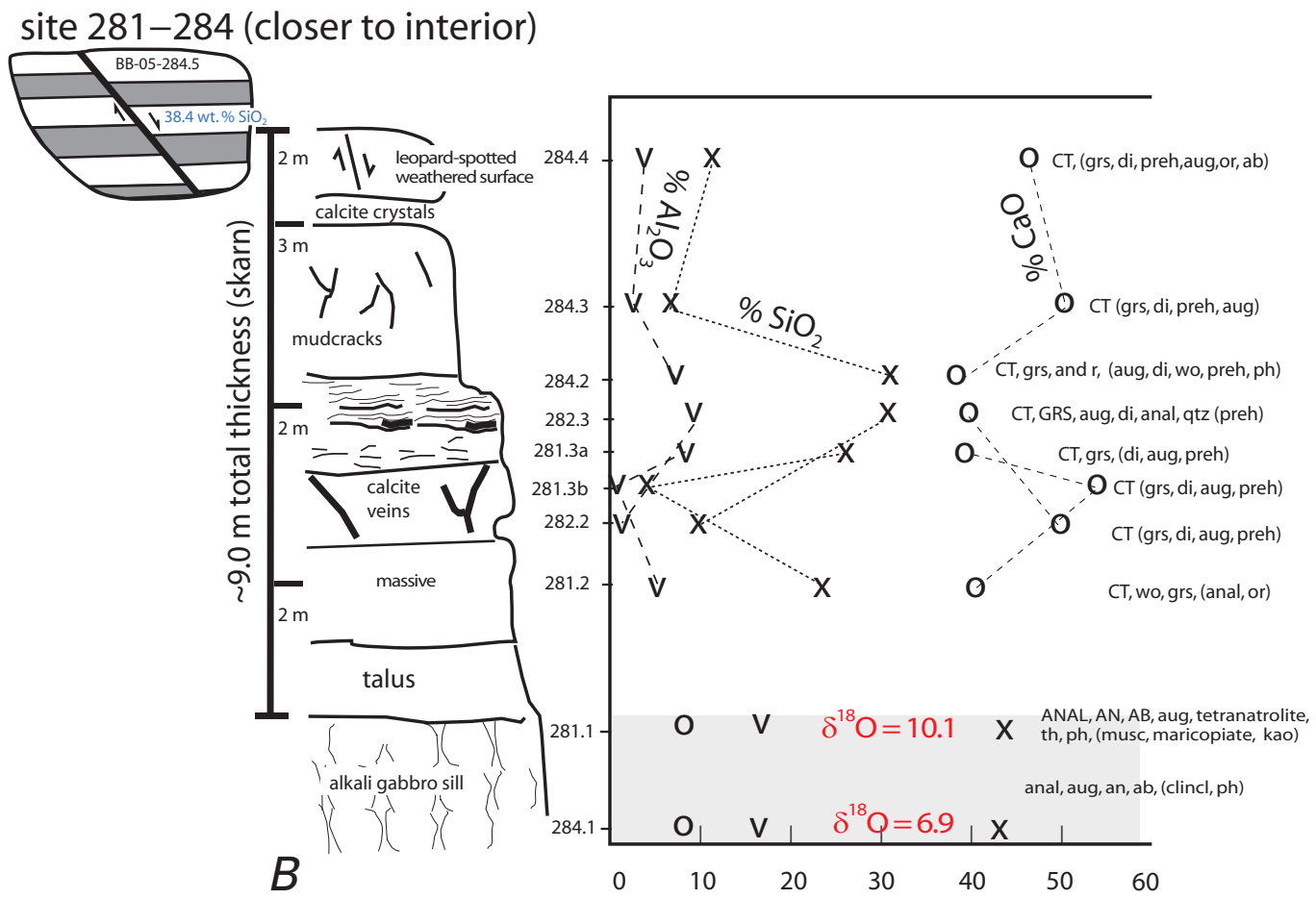


Figure 4-4 (continued). bedrock (Cretaceous Boquillas Formation) in which the Dagger Flats skarn formed. The Boquillas Formation consists of a series of alternating massive, marly mudstones and laminated silty carbonates that have been variably mineralized. Thickness of the capping skarn is approx. $4 \mathrm{~m}$. The skarn overlies a composite sill. Site 286 is located along the east side of a major northwest-trending fault and is located near the edge of the large sill body at depth. $B$, Schematic composite sketch of exposures at sites 281, 282, 283, and 284 (fig. 4-1B). Inset is a schematic sketch of a banded carbonate with tiny thrust fault; this sample is enriched with respect to silica (38.4 wt. \% $\mathrm{SiO}_{2}$ ). $C$, Schematic sketch of site 261 with contributions from sites 262, 248, and 287 (fig. 4-1B). D, Schematic sketch of site 247 (fig. 4-1B). site 261 (with contributions from 262, 248, 287)

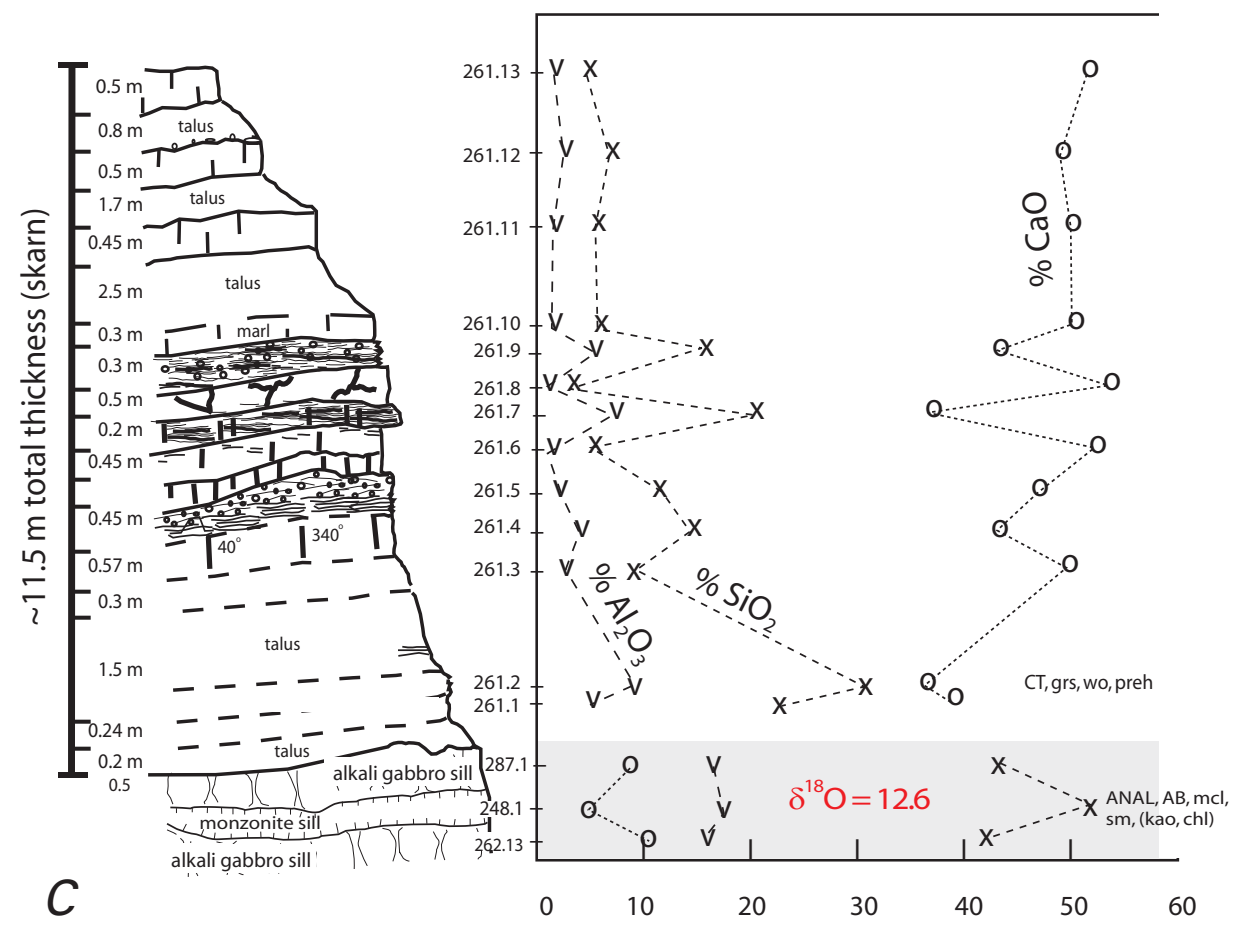

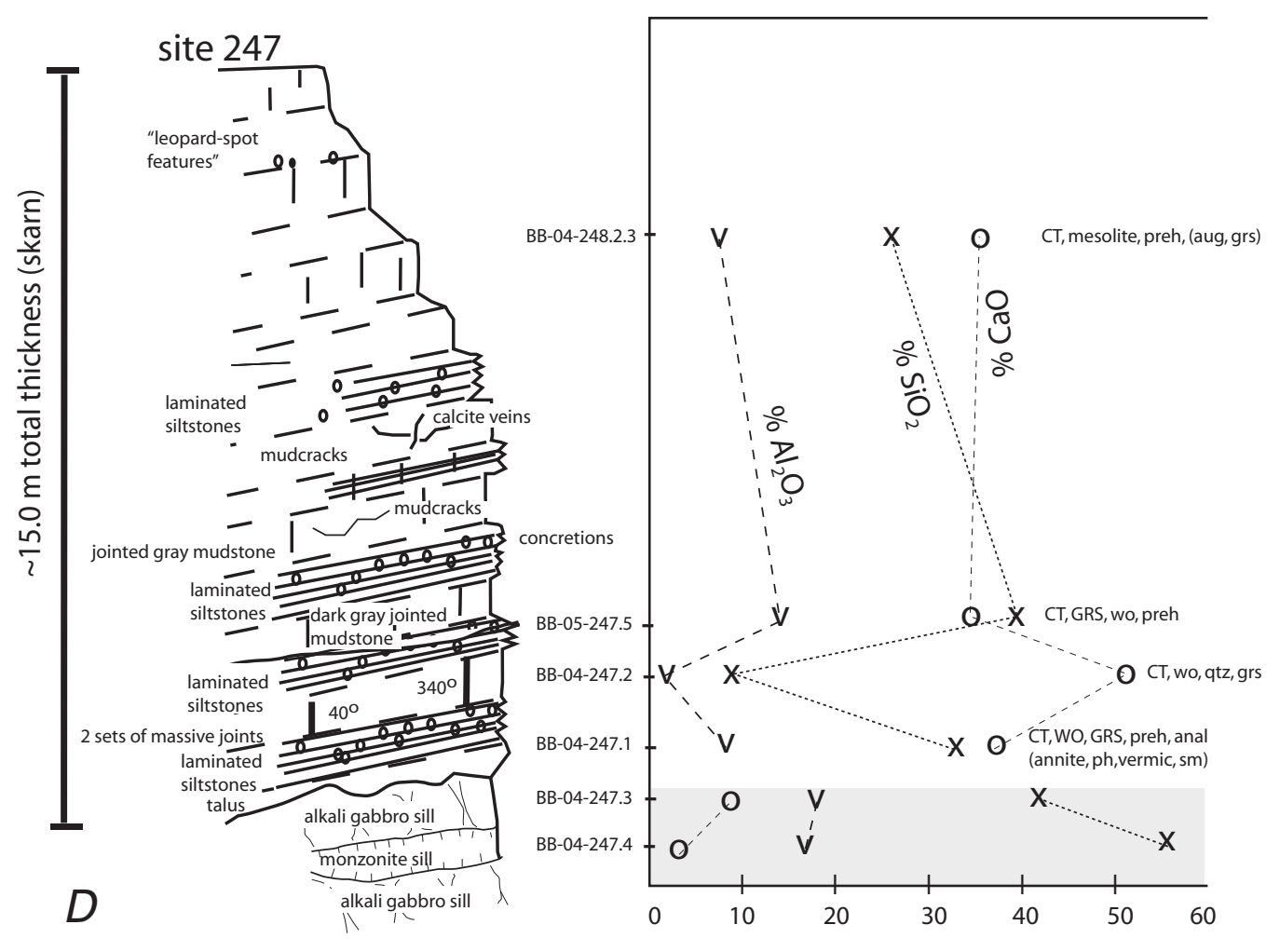




\section{Capping Skarns}

The skarn deposits at Dagger Flats are present in exposures capping the sill complex (fig. 4-5) in the Cretaceous Boquillas Formation. Thicknesses of the skarn deposits stratigraphically measured range from $<4 \mathrm{~m}$ to as thick as $20 \mathrm{~m}$; the complex extends for up to $10 \mathrm{~km}$ along its northwest strike. A series of alternating calcareous mudstones and fine-grained, well-sorted sandstones and siltstones, reflective of deposition in a near-shore marine environment, have been hydrothermally altered by heat, gases, and advecting fluids driven by emplacement of the underlying sills. Mineralogy of the skarn includes recrystallized calcite and quartz, wollastonite, grossular, prehnite, zeolites (mesolite, analcime), and clays (smectite). The carbonate host rock is strongly jointed and alteration is concentrated vertically along joints and fractured surfaces and laterally in the more porous fine-grained sandstones and siltstones (figs. 4-4 and 4-5). Alteration also appears zoned, with more intense alteration near the contact with the underlying sill complex (fig. 4-4). Fluid flow and heat were preferentially focused along well-defined vertical joints and the more porous, laminated, well-sorted siltstone units. Two sets of joints, oriented at $340^{\circ}$ with a subordinate set at $40^{\circ}$, are similar in orientation to the prevailing northwest-trending faults cutting the sill complex at Dagger Flats and controlling the orientation of the low-lying hills (figs. 4-1B and 4-2).

\section{Mineralogy and Geochemistry}

Results of X-ray diffraction mineralogical studies, confirmed by examination of thin sections, indicate that the calcsilicate skarn deposits at Dagger Flats predominantly contain recrystallized calcite and quartz, wollastonite $\left(\mathrm{CaSiO}_{3}\right)$, grossular garnet $\left(\mathrm{Ca}_{3} \mathrm{Al}_{2}\left(\mathrm{SiO}_{4}\right)_{3}\right)$, prehnite $\left(\mathrm{Ca}_{2} \mathrm{Al}_{2} \mathrm{Si}_{3} \mathrm{O}_{10}(\mathrm{OH})_{2}\right)$, and augite $\left((\mathrm{Ca}, \mathrm{Mg}, \mathrm{Fe})_{2} \mathrm{Si}_{2} \mathrm{O}_{6}\right)$ and (or) some other pyroxene.

This mineralogy is typical of skarn deposits. Wollastonite forms by the classic contact metasomatic reaction:

$$
\begin{gathered}
\mathrm{CaCO}_{3} \text { (limestone) }+\mathrm{SiO}_{2} \text { (quartz or hydrothermal } \\
\text { fluid) }=\mathrm{CaSiO}_{3}+\mathrm{CO}_{2}
\end{gathered}
$$

The $\mathrm{CO}_{2}$ may be removed from the system by advecting hydrothermal fluids. Grossular garnet, prehnite, and pyroxene (usually diopside) are typical skarn minerals and form by reaction of chemical components in the original limestones with introduced hydrothermal $\mathrm{SiO}_{2}$ (silica), $\mathrm{Na}$ (sodium), $\mathrm{Ca}$ (calcium), and other cations (Fe (iron), $\mathrm{Mg}$ (magnesium)).

Lower temperature, probably late-stage minerals include the zeolites mesolite $\left(\mathrm{Na}_{2} \mathrm{Ca}_{2} \mathrm{Al}_{6} \mathrm{Si}_{9} \mathrm{O}_{3}+8 \mathrm{H}_{2} \mathrm{O}\right)$ and analcime $\left(\mathrm{NaAlSi}_{2} \mathrm{O}_{6}+\mathrm{H}_{2} \mathrm{O}\right)$. The presence of the zeolite group mineral mesolite suggests low temperature conditions during waning stages of hydrothermal mineralization.

Chemical data for the skarn samples substantiate the mineralogical analyses and allow some quantification of mineral content. For example, assuming all carbonate carbon is in calcite, we calculate $\mathrm{CaCO}_{3}$ contents ranging from 10 to $80 \mathrm{wt}$ \% . This assumption is justified by the generally low $\mathrm{Mg}$ contents $(<2 \mathrm{wt} . \%)$ of these rocks and the lack of dolomite or other carbonate minerals. The large variations in $\mathrm{CaCO}_{3}$ contents also confirm field and thin section observations that the original limestone units are diverse in lithologic characteristics and porosity ranging from calcitic siltstones to relatively pure limestone units. The monzonite and alkali gabbro sills, in contrast, contain little carbonate, and thus did not experience metasomatic introduction of $\mathrm{CO}_{2}$ in the samples we have examined to date. The presence of smectite, kaolinite, and chlorite in the monzonite sill (fig. 4-4) and water contents as high as $4.1 \mathrm{wt}$. \% provides strong evidence, along with the oxygen isotope analysis, that the sills have experienced hydrothermal alteration.

Minor element geochemistry of the contact metasomatic skarn deposits indicates that these samples contain low contents of base metals (copper, lead, and zinc), and molybdenum. Concentrations of copper $(\mathrm{Cu})$ range from 51 to $150 \mu \mathrm{g} / \mathrm{g}$ in the alkali gabbro sills and from 8.0 to $25.0 \mu \mathrm{g} / \mathrm{g}$ in the monzonite sill. In the capping skarn deposit, concentrations of $\mathrm{Cu}$ range from 1.2 to $18.0 \mu \mathrm{g} / \mathrm{g}$; elevated $\mathrm{Cu}$ is present in the skarn at the contact with the sill where concentrations of $\mathrm{Cu}$ range from 29 to $44 \mu \mathrm{g} / \mathrm{g}$. Concentrations of lead $(\mathrm{Pb})$ range from 2.0 to $4.0 \mu \mathrm{g} / \mathrm{g}$ in the alkali gabbro sill and 7.0 to $9.4 \mu \mathrm{g} / \mathrm{g}$ in the monzonite sill. In the skarn, $\mathrm{Pb}$ concentrations range from 1.2 to $5.0 \mu \mathrm{g} / \mathrm{g}$ with higher $\mathrm{Pb}$ concentrations present at the sill contact ranging from 6.7 to $14.0 \mu \mathrm{g} / \mathrm{g}$. Concentrations of zinc (Zn) range from 78 to $100 \mu \mathrm{g} / \mathrm{g}$ in the alkali gabbro sill and from 81 to $94 \mu \mathrm{g} / \mathrm{g}$ in the monzonite sill. In the skarn deposit, $\mathrm{Zn}$ concentrations range from 16 to $31 \mu \mathrm{g} / \mathrm{g}$ with elevated $\mathrm{Zn}$ concentrations in the laminated siltstones ( 61 to $78 \mu \mathrm{g} / \mathrm{g}$ ) and at the sill contact ranging from 120 to $150 \mu \mathrm{g} / \mathrm{g}$. With respect to concentrations of molybdenum (Mo), both the alkali gabbro and monzonite sills are comparable and range from 1.2 to 6.2 $\mu \mathrm{g} / \mathrm{g}$. In the capping skarn deposit, concentrations of Mo are low $(0.79$ to $5.3 \mu \mathrm{g} / \mathrm{g})$ for the mineralized mudstones; however, in the skarn deposit, concentrations of Mo are somewhat elevated at the contact between the skarn and sill (27 to 110 $\mu \mathrm{g} / \mathrm{g}$ ), in faulted sections (46 $\mu \mathrm{g} / \mathrm{g}$ in sample BB-05-284.5), and in the mineralized laminated siltstone units (56 to 98 $\mu \mathrm{g} / \mathrm{g}$ ). Total iron (Fe) content ranges up to $3.2 \mathrm{wt} . \%$ as $\mathrm{Fe}_{2} \mathrm{O}_{3}$ and total sulfur (S) ranges from $<0.05$ to $0.43 \mathrm{wt}$. \%, which suggests most $\mathrm{Fe}$ is in the silicates, and most of the sulfur occurs as pyrite or pyrrhotite. Low Fe content in the unaltered Cretaceous limestone units suggests that $\mathrm{Fe}$ was probably introduced during metasomatism.

Geochemical and mineralogical data show how the extent of mineralization and recrystallization was affected by the porosity of the host rock (fig. 4-5). Alternating grey massive limey mudstones and orange-stained laminated siltstones are present in many skarn exposures in the Cretaceous Boquillas Formation (fig. 4-4A). Sample BB-04-247.5 is from a laminated silty limestone unit full of secondary concretions and corresponds to an enriched silica $\left(\mathrm{SiO}_{2}\right)$ content of 39.8 wt. \% (fig. 4-4D). Correspondingly, the major 

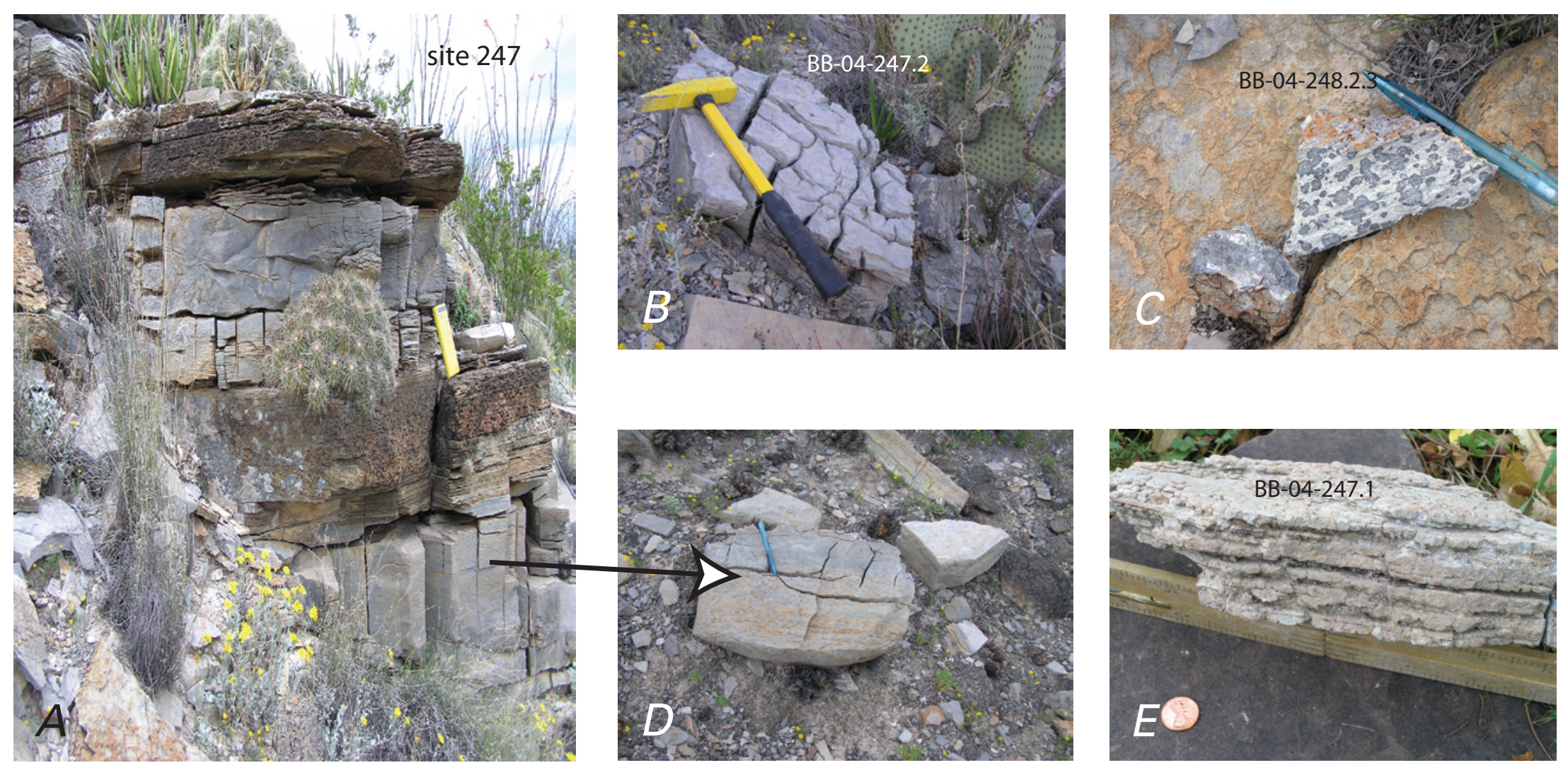

Figure 4-5. Photographs of features exposed in skarns at Big Bend National Park. A, Exposure of skarn in the Cretaceous Boquillas Formation at site 247 (fig. 4-1B); total thickness of skarn here is about $12 \mathrm{~m}$. B, Photograph of mineralized carbonate mudstone (BB-04-247.2) with mudcracks. $C$, Photograph of mineralized carbonate (BB-04-248.2.3) showing "leopard spot" replacement. D, Photograph of skarn showing mudstone in contact with mineralized laminated silty carbonate. E, Photograph of mineralized, laminated silty carbonate (BB-04-247.1). 

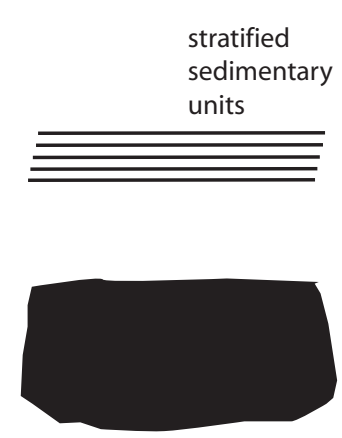

magma at depth A

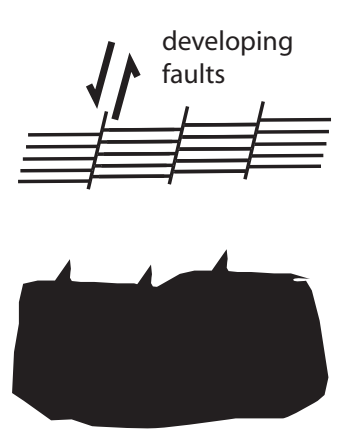

magma at depth

B

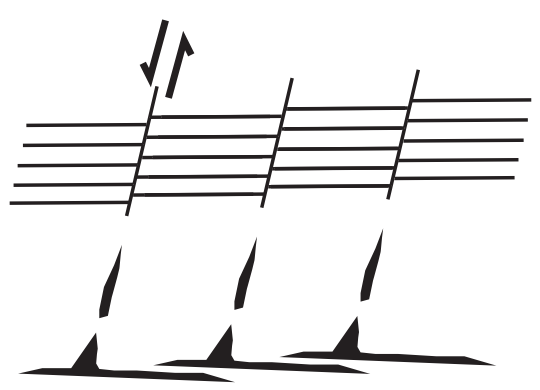

magma at depth

C

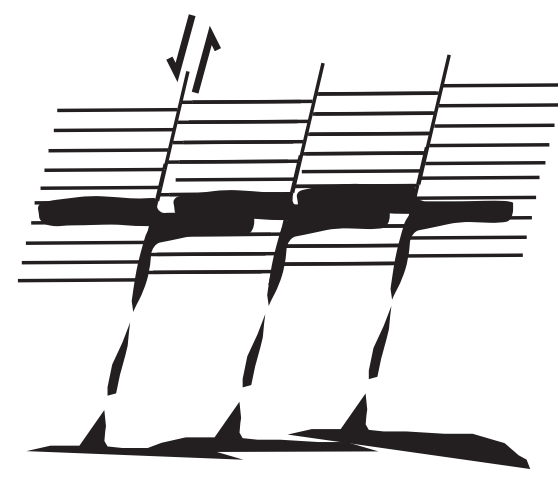

magma at depth

D

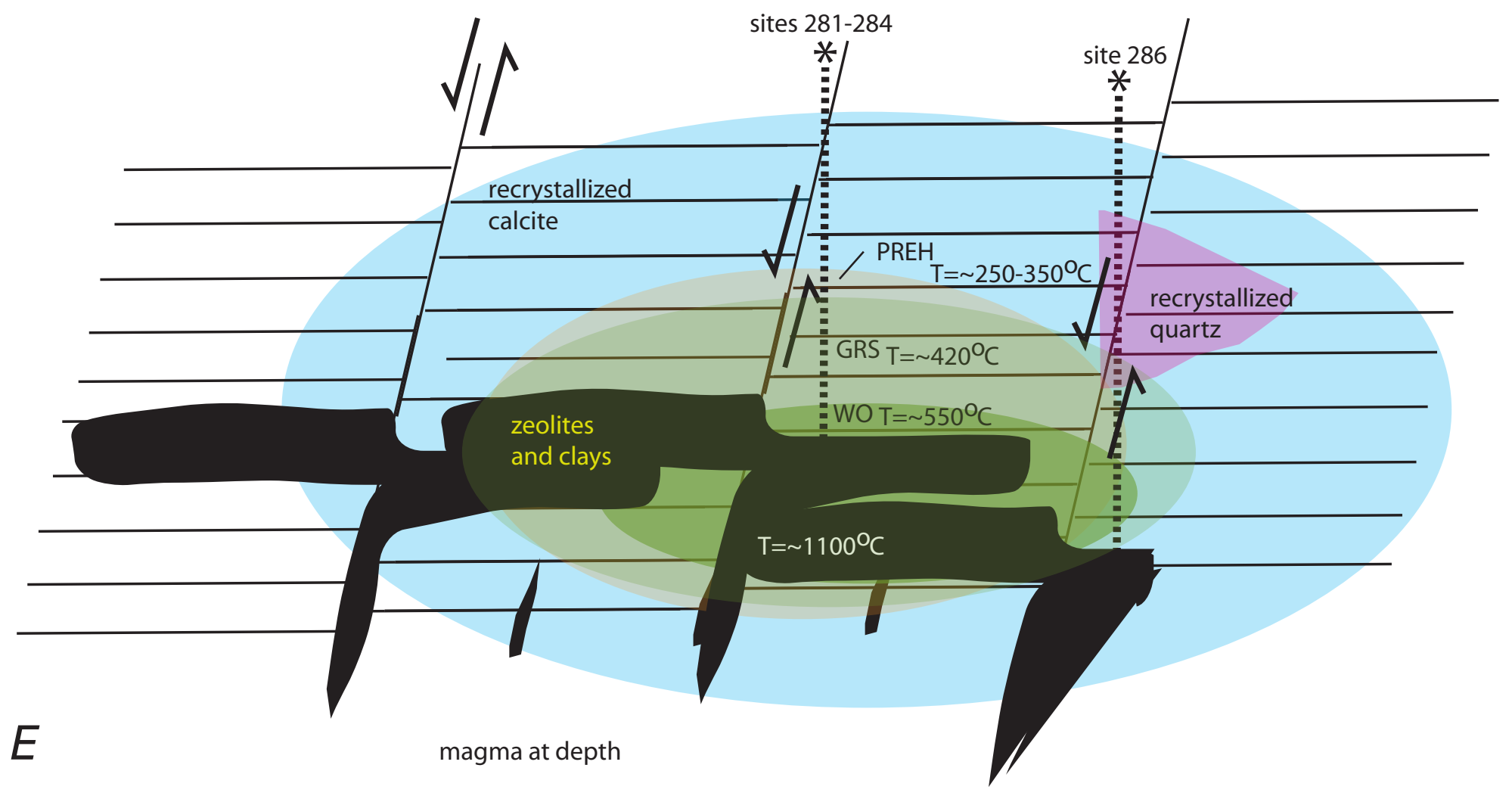


Figure 4-6 (facing page). Simplified schematic diagrams illustrating a model for the intrusion of sills at Dagger Flats into the Cretaceous Boquillas Formation and formation of the skarn. $A$, Magma chamber at depth below sequence of sedimentary rocks. $B$, Fractures in sedimentary rocks form in conjunction with extensional tectonism, allowing magma at depth to flow toward space created by fractures. Dike propagation is focused on fractures where magma fills voids created by extension. $C$, Dike propagation continues along extensional fractures. Magmatic temperatures for alkali gabbros are about $1100^{\circ} \mathrm{C}$. As the alkali gabbroic dike propagates along the fracture, the magma heats the wall rock. An increase of heat to the wall rock results in facilitating the ascent of magma. $D$, At some level higher in the crust (in this case, the level of the Cretaceous Boquillas Formation), the presence of lower density strata may result in a change to the overall stress field. The upward ascent of magma in the propagating dike, controlled by location of the fractures and axis of least compressive stress (at depth most likely horizontal resulting in dike propagation in the vertical plane) is affected by a change in stress field. At shallower depths in the crust, the least compressive stress field changes from a horizontal plane to a vertical plane affecting the upward ascent of dike propagation to flow where the axis of least compressive stress becomes dominant and magmas flows horizontally. E. Close-up diagram of figure 4-6D showing schematically the thermal aureole developed in the host rock (in this case, the Cretaceous Boquillas Formation) in response to the emplacement of hot, mostly mafic magma, associated magmatic gases rich in $\mathrm{H}_{2} \mathrm{O}, \mathrm{CO}_{2}$, and $\mathrm{H}_{2} \mathrm{~S}$, and percolating hydrothermal fluids. Minerals in the thermal aureole and their associated temperatures of formation are depicted schematically with the higher temperature minerals such as wollastonite (WO) forming in the limestone unit at the contact with the sill and lower temperature minerals found farther away from the intrusion. Recrystalized quartz and calcite are found at the perimeter of the thermal aureole. A range of alteration mineral minerals are present in the sills and represent a broad range of temperatures of formation associated with hotter magmatic gases and lower temperature hydrothermal fluids. PREH, prehnite; GRS, grossular garnet. alteration minerals in this sample are grossular garnet and recrystallized calcite, with minor wollastonite and prehnite. A lower unit in the section (BB-04-247.2) is a dense marly limestone containing well-developed mudcracks (fig. 4-5B). In contrast to BB-04-247.5, sample BB-04-247.2 has significantly lower total silica content $\left(9.29\right.$ wt. \% $\mathrm{SiO}_{2}$, fig. 4-4D), suggesting this carbonate unit was less permeable and not as influenced by the infiltration of reactants and heat. Major alteration mineralogy of BB-04-247.2 is calcite, most likely recrystallized, with minor wollastonite, quartz, and grossular garnet. Sample BB-04-247.1 (fig. 4-4D) is at the base of the skarn in contact with the underlying composite sill. This sample is a laminated, fine-grained, limey siltstone (fig. 4-5E) and is full of mineralized concretions up to $4 \mathrm{~mm}$ in diameter. Like BB-04-247.5, sample BB-04-247.1 contains enriched silica (33.2 wt. \% $\mathrm{SiO}_{2}$, fig. 4-4D), and its major alteration mineralogy consists of wollastonite, grossular garnet, and calcite with minor alteration mineralogy of prehnite and analcime. Lower temperature zeolite and clay alteration formed in later stages where meteoric water infiltrated and reacted with the cooling sill. Sample BB-04-247.1 was subjected to both early high-temperature and later low-temperature alteration. The relationship between varying silica content and the extent and type of alteration with respect to the physical and chemical characteristics of the host rock is seen repeatedly in the skarn exposures at Dagger Flats (fig. 4-4).

Faulting also influenced the infiltration of mineralizing fluids and heat into the carbonate host and is an important component aiding in the transport of fluids. Faulting also may have played a significant role in transporting mineralizing fluids. Sample BB-05-284.5 is associated with well developed slickensides with recrystallized calcite and quartz along its fault plane (fig. 4-4B) and is enriched with respect to Mo, $\mathrm{Zn}$, and $\mathrm{Cu}$. 


\section{Discussion}

About $32 \mathrm{Ma}$, north-northeast-trending faults formed in and around BBNP and were associated with south-southwest extension. This tectonic activity coincided with magmatic activity, which included intrusion of large oval-shaped sill complexes in the northeast quadrant of BBNP. Composition of the alkaline tabular intrusions at Dagger Flats is predominantly alkali gabbro with subordinate monzonite intrusions. Monzonite bodies within alkali gabbroic sills and laccoliths are common features in the Big Bend region and most likely formed as in-situ differentiates involving crystal fractionation (fig. 4-3B) (Carman, 1994).

Timing of emplacement of the Dagger Flats sills is closely contemporaneous with eruption of large-volume rhyolitic ignimbrites and intrusion of later felsic dikes less than 10 $\mathrm{km}$ to the south at the Pine Canyon caldera. Intrusive activity at Dagger Flats occurred about $32.47 \pm 0.41 \mathrm{Ma}$, while the predominantly rhyolitic volcanic activity at the Pine Canyon caldera ranged from $32.22 \pm 0.12 \mathrm{Ma}$ to $30.86 \pm 0.41 \mathrm{Ma}$ (Morgan and others, 2006).

Emplacement of the alkali gabbroic sills at Dagger Flats coincides with early tectonic extension in the area. From field relationships, such as a well-preserved chilled margin in the monzonite bodies within the alkali gabbroic sills, it is clear the monzonite sheets were quenched in the slightly younger but already cooled alkali gabbro. The monzonite sills, which make up only a small volumetric fraction of the total sill (probably $<2$ percent total volume).

As shown on the magnetic intensity map (fig. 4-2B), an oval, northwest-trending body with positive magnetic intensities is present below Dagger Flats extending to the south and southeast and may be related to other similar structures in the vicinity, such as those that underlie the McKinney Hills (fig. 4-2B), and the Rosillos Mountains and Grapevine Hills (fig. 4-1). These features are large $\left(>10 \mathrm{~km}^{2}\right)$, oval intrusive bodies. Samples taken from each of these areas indicate that the Dagger Flats sills and those in the Rosillos Mountains to the west are dominantly alkali gabbroic in composition, whereas compositions of samples collected from exposures in the McKinney Hills and the Grapevine Hills range from syenitic to quartz monzonitic to granitic (figs. 4-1 and 4-2). Additional studies at McKinney Hills and the Grapevine Hills may be warranted to determine the full range of compositions for their intrusions. The similar magnetic intensities of these bodies compared to those at Dagger Flats and the Rosillos Mountains indicate that they are probably also alkali gabbroic in composition. The more felsic-rich silllike subhorizontal sheets at McKinney Hills and laccoliths at Grapevine Hills that are now exposed may represent only a small fraction of the total intrusions. The total magnetic intensity values of these sill and laccolith bodies indicate that the larger, parental part of the intrusion is still buried and is alkali gabbroic or more mafic in composition than what is exposed.
Comparison of mineralogic, chemical, and oxygen isotope data for the Dagger Flats skarn deposits with other similar occurrences suggests that main stage skarn formation in the limestone rocks of the contact zone at Dagger Flats resulted from high-temperature reaction with magmatic fluids (Bowman, 1998). Skarn mineralogy adjacent to the sills is determined by the composition and physical characteristics of the intrusive body and the physical and chemical nature of the carbonate host rock. At Dagger Flats, emplacement of the alkali gabbroic sills occurred at temperatures that exceeded $1100^{\circ} \mathrm{C}$ and resulted in intense heating and degassing of magmatic gases $\left(\mathrm{H}_{2} \mathrm{O}, \mathrm{CO}_{2}\right.$, and $\left.\mathrm{H}_{2} \mathrm{~S}\right)$. These gases escaped into the adjacent carbonate strata and promoted reactions, typically at temperatures of $250-550^{\circ} \mathrm{C}$, which produced skarn minerals such as wollastonite, garnet, pyroxene, and prehnite (fig. 4-6). Additionally, intrusion of the sills into carbonate strata promoted recrystallization of the calcite and quartz that are present in the host rock. Following the main stage of skarn mineralization at Dagger Flats, meteoric waters convected in the skarn and the sills resulted in lower temperature (100$350^{\circ} \mathrm{C}$ ) alteration of the host rocks and produced additional alteration including the formation of chlorite, zeolites, and clays (fig. 4-6), as well as other sheet silicates, such as mica.

\section{References Cited}

Anderson, E.D., Finn, C.A., Scott, R.B., and Snee, L., 2004, Mapping and visualizing faults using aeromagnetic data and GIS in northern Big Bend National Park, Texas [abs.]: Geological Society of America Abstracts with Programs, v. 36, no. 5, p. 127.

Bird, D.K., Schiffman, P., Elder, W.A., Williams, A.E., and McDowell, S.D., 1984, Ca Flc-silicate mineralization in active geothermal systems: Economic Geology, v. 79, p. 671-695.

Bowman, J.R., 1998, Stable-isotope systematics of skarns, in Lentz, D.R., ed., Mineralized intrusion-related skarn systems: Mineralogical Association of Canada Short Course Series, v. 26, p. 99-146.

Carman, M.F., 1994, Mechanisms of differentiation in shallow mafic alkaline intrusions, as illustrated in the Big Bend area, western Texas: Journal of Volcanology and Geothermal Research, v. 61, p. 1-44.

Chevalier, L., and Woodford, A., 1999, Morph-tectonics and mechanism of emplacement of the dolerite rings and sills of the western Karoo, South Africa: South African Journal of Geology, v. 102, p. 43-54.

Henry, C.D., and Price, J.G., 1984, Variations in caldera development in the Tertiary volcanic field of Trans-Pecos Texas: Journal of Geophysical Research, v. 89, no. B10, p. 8,765-8,786. 
Lentz, D.R., 1998, Mineralized intrusion-related skarn systems, in Lentz, D.R., ed., Mineralized intrusion-related skarn systems: Mineralogical Association of Canada Short Course Series, v. 26, preface.

Maxwell, R.A., 1968, The Big Bend of the Rio Grande-A guide to the rocks, landscape, geologic history, and settlers of the area of Big Bend National Park: Bureau of Economic Geology Guidebook 7, 138 p.

Middlemost, E.A.K., 1994, Naming materials in the magma/ igneous rock system: Earth-Science Reviews, v. 37, p. 215-224.

Morgan, L.A., Shanks, W.C.P., and McIntosh, W.C., 2006, Late Oligocene igneous activity in Big Bend National Park, Texas-Contemporaneous activity at Dagger Flats sill complex and Pine Canyon caldera [abs.]: Geological Society of America Abstracts with Programs, v. 38, no. 7, p. 34.
Smallwood, J.R., and Maresh, J., 2002, The properties, morphology and distribution of igneous sills-Modeling, borehole data and 3D seismic data from the Faeroe-Shetland area, in Jolley, D.W., and Bell, B.R., eds., The North Atlantic igneous province-Stratigraphy, tectonic, volcanic, and magmatic processes: Geological Society of London, Special Publication 197, p. 271-306.

Thomson, K, 2004, Sill complex geometry and internal architecture-A 3D seismic perspective, in Breitkreuz, C., and Petford, N., eds., Physical geology of high-level magmatic systems: Geological Society of London, Special Publication 234, p. 229-232.

Thomson, K., and Hutton, D., 2004, Geometry and growth of sill complexes-Insights using 3D seismic from the North Rockall Trough: Bulletin of Volcanology, v. 66, p. 364-375. 


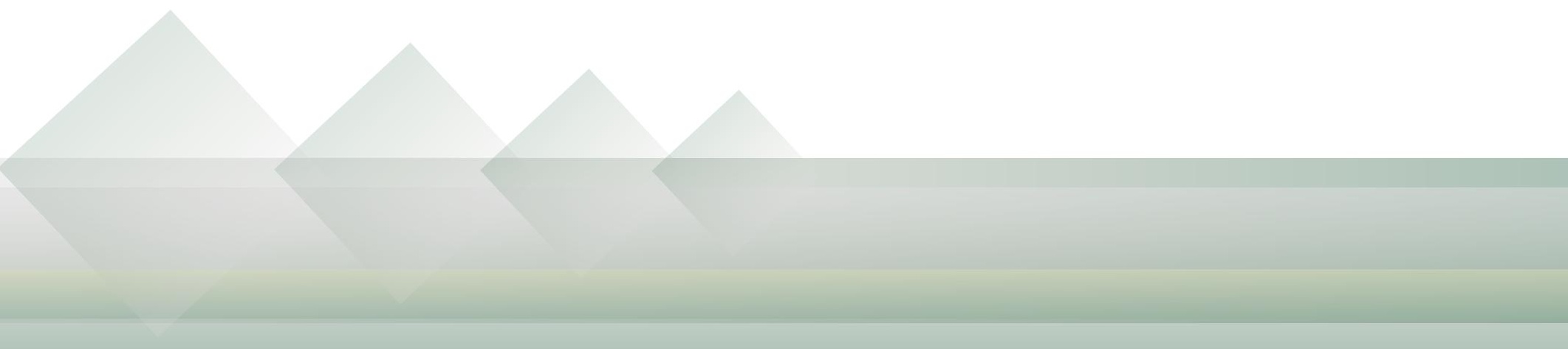




\title{
5. Evaluation of Mercury Contamination at Inactive Mercury Mines in and around Big Bend National Park
}

\author{
By John E. Gray, Peter M. Theodorakos, and David P. Krabbenhoft
}

\section{Abstract}

The concentration of mercury in mine waste, stream sediment, water, soil gas, and air was determined in and around inactive mercury mines in the Big Bend region of southwest Texas to evaluate possible contamination and transport of mercury into local ecosystems that eventually flow into the Rio Grande. In addition, concentrations of methylmercury were measured in mine waste, stream sediment, and water to evaluate conversion from inorganic mercury to highly toxic organic mercury compounds, such as methylmercury. Mine waste contains mercury and methylmercury concentrations as high as $19,000 \mu \mathrm{g} / \mathrm{g}$ and 1,500 $\mathrm{ng} / \mathrm{g}$, respectively, which are highly elevated but similar to those reported from other mercury mines worldwide. Mercury concentrations in stream sediment samples were generally below the probable effect concentration of $1.06 \mu \mathrm{g} / \mathrm{g}$ (the concentration above which harmful effects are likely to be observed in sediment dwelling organisms), but mercury concentrations in mine waste were found to exceed this concentration (however, this standard is a sediment quality guideline and not directly applicable to mine waste). Mercury concentrations in water samples collected vary from 1.2 to $14 \mathrm{ng} / \mathrm{L}$ in mine runoff, 2.7 to $13 \mathrm{ng} / \mathrm{L}$ in the Rio Grande, 0.68 to 9.7 $\mathrm{ng} / \mathrm{L}$ in baseline streams, and 0.049 to $10 \mathrm{ng} / \mathrm{L}$ in wells and springs. Mercury concentrations found in all water sampled in this study were significantly below the 2,000 ng/L drinking water standard for mercury and were also generally below the $12 \mathrm{ng} / \mathrm{L}$ aquatic wildlife standard for mercury, which are recommended by the U.S. Environmental Protection Agency (EPA). Although mercury and methylmercury concentrations are locally high in some mine waste samples, little mercury appears to be exported from these mercury mines through stream sediment and water primarily because of the arid climate, lack of precipitation, and resulting lack of mine runoff in this region. Mercury emission data for the mines studied suggest that, although concentrations of mercury in soil gas in mine waste are elevated (as much as $21,000 \mathrm{ng} / \mathrm{m}^{3}$ at Mariscal mine), persistent wind in southwest Texas disperses mercury in air $\left(2.5-59 \mathrm{ng} / \mathrm{m}^{3}\right)$ within a few meters of the ground surface to concentrations similar to or slightly higher than those found in air at regional baseline sites $\left(1.2-17 \mathrm{ng} / \mathrm{m}^{3}\right)$. In addition, baseline mercury measurements in air and soil gas in Big Bend National Park further suggest little regional influence of mercury emissions from these mines.

\section{Introduction}

Mining of mercury was prevalent in the Big Bend area beginning about 1888 with intermittent operations continuing until about 1973 (Sharp, 1980; Avery and others, 1996). There are no mercury mines presently operating in the United States, primarily because of environmental concerns related to mercury toxicity and the significant recycling of mercury that reduces the demand for new resources (Sznopek and Goonan, 2000). Several inactive mercury mines constitute the Terlingua district, located in and around Big Bend National Park (BBNP). Total production from this region exceeded 5,000 t of mercury (Sharp, 1980). Consequently, the Terlingua district ranks as the third largest mercury-producing region in the United States; only mercury mines in the California Coast Ranges (100,000 t of mercury) and McDermitt, Nev., (10,000 t of mercury) are larger (Rytuba, 2000; Gray and others, 2002). Mariscal, one of the smaller mercury mines of the Terlinugua district, located in the southern part of BBNP, produced about 50 t of mercury during mining between about 1900-1943 and became part of BBNP when the park was established in 1944. Access to these mines is generally unrestricted, especially in BBNP, and as a result, tourists often visit these sites. Runoff and downstream transport of waste containing mercury from the mines potentially contaminates streams and rivers in the area, which are located in or flow through BBNP and eventually flow into the Rio Grande (fig. 5-1). Because the Mariscal mine is the only mercury mine in the park, it was the dominant focus of U.S. Geological Survey (USGS) mercury contaminant research in BBNP. 


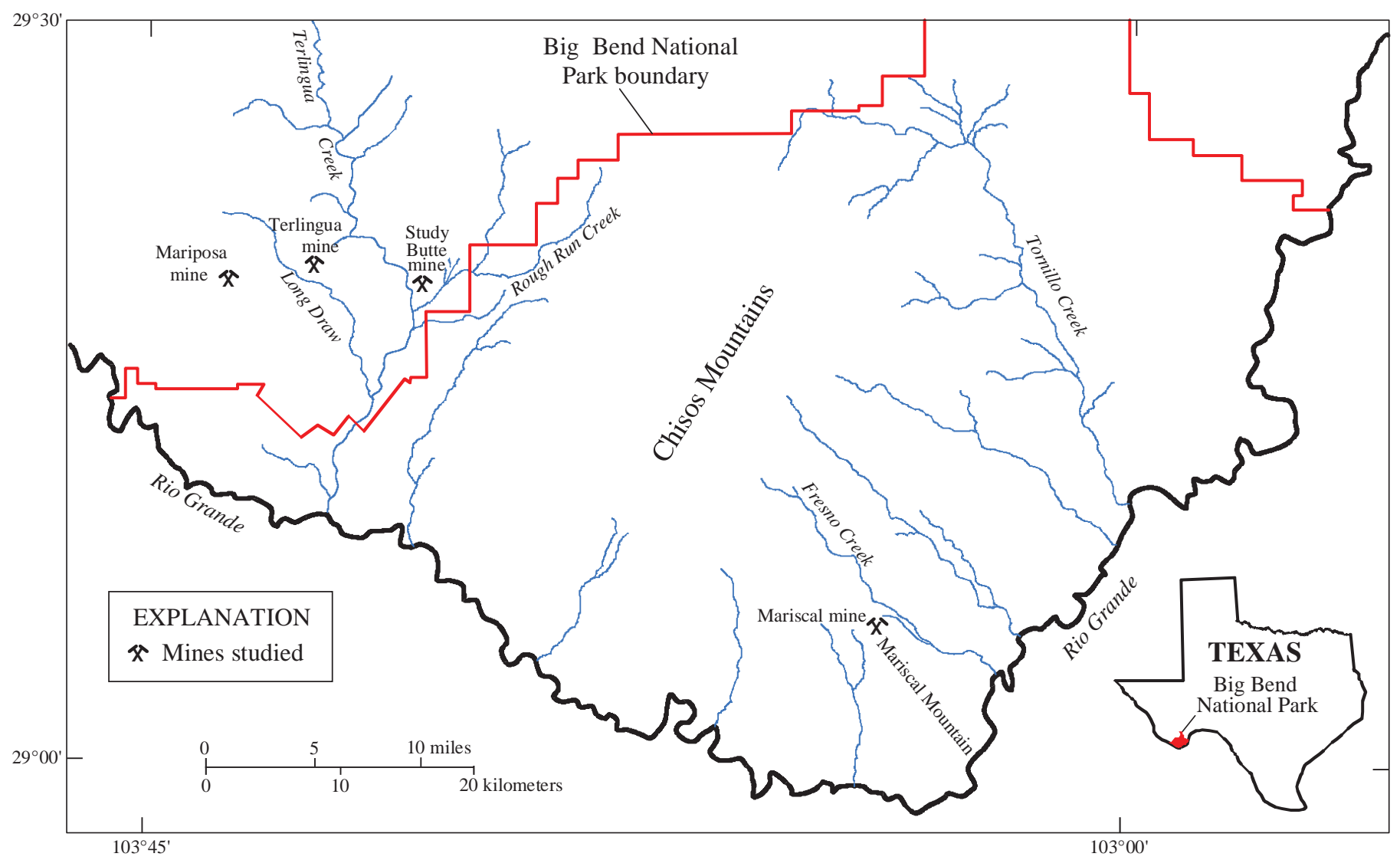

Figure 5-1. Location of the study area and mercury mines studied.

The most significant environmental concerns associated with mercury mines include mercury contamination in mine waste, sediment, and soil in and around the mines as well as evasion of mercury gas from these mined areas. Evaluation of downstream transport of mercury and chemical and microbial transformation of mercury to bioavailable organic compounds such as methylmercury, the most toxic of the mercury compounds, is especially important in areas of past mercury mining. Microbial activity is primarily responsible for the conversion of inorganic mercury to organic mercury compounds; although abiotic, chemical mercury methylation is also a known conversion process (Ullrich and others, 2001). Methylmercury is particularly problematic because it is water soluble and is readily transferred from the sediment column to the water column, then to aquatic wildlife. Methylmercury bioaccumulates in living organisms; its concentration increases with increasing trophic position in the food chain (biomagnification), and it is a human neurotoxin. Conversion and transfer of methylmercury from active and inactive mercury mines to surrounding ecosystems is a potential concern worldwide (Gray and others, 2004). As part of the USGS project in BBNP, concentrations of mercury and (or) methylmercury were measured in mine waste, stream sediment, soil, water, and air around several mines in order to evaluate mercury contamination at these sites.

\section{Mine Waste and Sediment}

The Terlingua district includes more than 30 separate mines (Ross, 1941), but the USGS mercury contaminant studies summarized in this report focused mostly on the Study Butte, Mariposa, Terlingua (also known as the Chisos mine), and Mariscal mines (fig. 5-1). Similar to most mercury mines worldwide, mercury ore at the studied mines is dominantly cinnabar (hexagonal $\mathrm{HgS}$ ), but minor metacinnabar (isometric $\mathrm{HgS})$, elemental mercury $\left(\mathrm{Hg}^{\circ}\right)$, and oxychlorides such as terlinguaite $\left(\mathrm{Hg}_{2} \mathrm{ClO}\right)$ and eglestonite $\left(\mathrm{Hg}_{2} \mathrm{Cl}_{2} \mathrm{O}\right)$ were identified at some mines (Ross, 1941; Sharp, 1980).

Extraction of mercury during mining is generally carried out in a furnace where mercury ore is heated to temperatures of about $600-700^{\circ} \mathrm{C}$ (a process termed retorting), which easily converts the ore (mostly cinnabar) to elemental mercury, the final mercury product that is used for commercial trade (Bailey and Phoenix, 1944). This ease of conversion combined with the unique properties of elemental mercury is the reason why mercury has been mined for such a long time, more than 2,000 years. However, the retorting of mercury ore is known to be an inefficient and incomplete process, and as a result, mine waste found at most mercury mines contains unconverted cinnabar, elemental mercury, and other mercury compounds formed during processing (Gray and others, 2006). Even after many years of inactivity, areas affected 
by mercury mining continue to be characterized by highly elevated mercury concentrations as a result of the inefficient and incomplete mercury extraction process (Gray, 2003). One consequence of mercury mining is that considerable mine waste is generated during ore processing; this waste is typically discarded at the site of mining, and much of this waste contains toxic mercury compounds. There are greater than $2,000,000 \mathrm{~m}^{3}$ of mine waste remaining in the Terlingua district and approximately $30,000 \mathrm{~m}^{3}$ at the Mariscal mine (fig. 5-2) (Gray and others, 2006). This mine waste contains elevated mercury concentrations as a result of incomplete mercury recovery and generation of mercury byproduct compounds (such as calomel, $\mathrm{Hg}_{2} \mathrm{Cl}_{2}$ ) during retorting, some of which are water soluble (Kim and others, 2003; Gray and others, 2004). Thus, these mine wastes contain significant amounts of mercury potentially available for downstream transport, leaching, and biogeochemical transformation to methylmercury. Runoff from mines in the Terlingua district potentially transports various mercury compounds downstream into tributaries that flow into Terlingua Creek, which flows through the western side of BBNP and eventually into the Rio Grande (fig. 5-1). Similarly, runoff from the Mariscal mine is transported downstream to Fresno Creek, which flows into the Rio Grande.

Mercury concentrations in mine waste samples collected from the Terlingua district vary widely from 4.1 to 19,000 $\mu \mathrm{g} / \mathrm{g}$ (fig. 5-3) and methylmercury concentrations vary from 0.051 to $1,500 \mathrm{ng} / \mathrm{g}$. Mine waste collected from the Mariscal mine also contains elevated mercury concentrations (6.9-150 $\mu \mathrm{g} / \mathrm{g})$ and methylmercury concentrations $(0.55-1.5 \mathrm{ng} / \mathrm{g})$, although these concentrations are generally lower than those found at other mines in the Terlingua district. Lower mercury concentrations at Mariscal are probably related to more efficient recovery of mercury at this mine during ore retorting (Gray and others, 2006). Mercury and methylmercury concentrations in mine waste collected from the Terlingua district are highly elevated relative to those in stream sediment samples collected from uncontaminated regional baseline sites in this study. Baseline samples contain mercury ranging from less than 0.010 to $0.028 \mu \mathrm{g} / \mathrm{g}$ (fig. 5-3) and methylmercury ranging from less than 0.010 to $0.025 \mathrm{ng} / \mathrm{g}$. Mercury concentrations in most mine waste samples also exceed the probable effect concentration (PEC) of $1.06 \mu \mathrm{g} / \mathrm{g}$ in sediment; harmful effects are likely to be observed in sediment dwelling organisms when mercury concentrations exceed this level (MacDonald and others, 2000). (It should be noted, however, that this concentration is a mercury sediment quality guideline and is not directly applicable to mine waste.) Highly elevated and variable mercury concentrations in waste from the mines studied relates to the presence of cinnabar and other mercury compounds. Due to the highly toxic nature of methylmercury, concentrations of this compound are most noteworthy. At present, it is unclear whether the methylmercury concentrations in mine waste reported here would be harmful to human health if such mine waste were inhaled because health guidelines for methylmercury in sediment have not been established.
Stream sediment samples were collected along Fresno Creek downstream from the Mariscal mine to evaluate transport of mercury and methylmercury to the Rio Grande, about $10 \mathrm{~km}$ downstream from the mine. These stream sediment samples show significant dilution of mercury and methylmercury concentration with increasing distance from the mine. No structures have been built at the Mariscal mine to prevent erosion and downslope transport of mine waste, so some mine waste material (although minor) is present in stream beds within a few meters of the Mariscal mine. Concentrations of mercury $(7.9 \mu \mathrm{g} / \mathrm{g})$ and methylmercury $(0.62 \mathrm{ng} / \mathrm{g})$ are elevated in the stream sediment sample collected nearest to the Mariscal mine ( $0.5 \mathrm{~km}$ downstream); however, within a few kilometers downstream, mercury and methylmercury concentrations are similar to those found in the regional baseline stream sediment sites. In addition, only the stream sediment sample collected nearest the Mariscal mine contains mercury that exceeded the PEC of $1.06 \mu \mathrm{g} / \mathrm{g}$ in sediment. Mariscal is the closest mercury mine to the Rio Grande, but geochemical results from the Mariscal mine area suggest that processes favoring microbial mercury methylation are limited and that the transference of significant mercury and methylmercury from mine waste to downstream sediment then to the Rio Grande is unlikely.

\section{Water}

To evaluate potential water-borne mercury contamination, water samples were collected from five sources: (1) near mercury mines, (2) the Rio Grande, (3) uncontaminated baseline streams, (4) hot and cold springs, and (5) wells in the Big Bend region. Because the study area is in the Chihuahuan Desert, there is little precipitation ( $<25 \mathrm{~cm} /$ year) and little mine runoff; therefore, mine water runoff was collected downstream from the Study Butte and Terlingua mines, the only mine sites where water was found flowing during fieldwork from 2003-2007. Mercury concentrations in seven samples of mine water runoff varied from 1.2 to $14 \mathrm{ng} / \mathrm{L}$ and methylmercury ranged from 0.034 to $1.3 \mathrm{ng} / \mathrm{L}$, whereas water samples collected from nine uncontaminated baseline stream sites in BBNP were found to contain mercury ranging from 0.68 to $9.7 \mathrm{ng} / \mathrm{L}$ and methylmercury ranging from 0.026 to $0.61 \mathrm{ng} / \mathrm{L}$ (fig. 5-4). Water samples collected from 10 sites along the Rio Grande contained mercury ranging from 2.7 to $13 \mathrm{ng} / \mathrm{L}$ and methylmercury ranging from 0.22 to $2.0 \mathrm{ng} / \mathrm{L}$, and 20 water samples collected from wells and springs in BBNP contained mercury concentrations ranging from 0.049 to $10 \mathrm{ng} / \mathrm{L}$ and methylmercury ranging from $<0.020$ to $0.099 \mathrm{ng} / \mathrm{L}$.

Average mercury concentrations measured in collected water samples are $8.5 \mathrm{ng} / \mathrm{L}$ in mine runoff, $5.1 \mathrm{ng} / \mathrm{L}$ in the Rio Grande, $4.2 \mathrm{ng} / \mathrm{L}$ in baseline streams, and $1.7 \mathrm{ng} / \mathrm{L}$ in wells and springs. These data indicate that wells and springs in BBNP contain the lowest mercury concentrations of the water samples collected, and thus, ground water collected in BBNP has lower mercury concentrations than those found in surface 
Figure 5-2. Photographs of Study Butte and Mariscal mercury mines and mine waste. $A$, View of the Study Butte mine showing large volume mine wastes in the foreground. $B$, View of the Mariscal mercury mine in Big Bend National Park. Mariscal was one of the smaller mines studied, was mined from 1900-1943, and became part of Big Bend National Park when the park was designated in 1944. C, View of a dilapidated brick retort at the Mariscal mine. Bricks from this retort still contain significant mercury even though the mine has not operated since the 1940s.

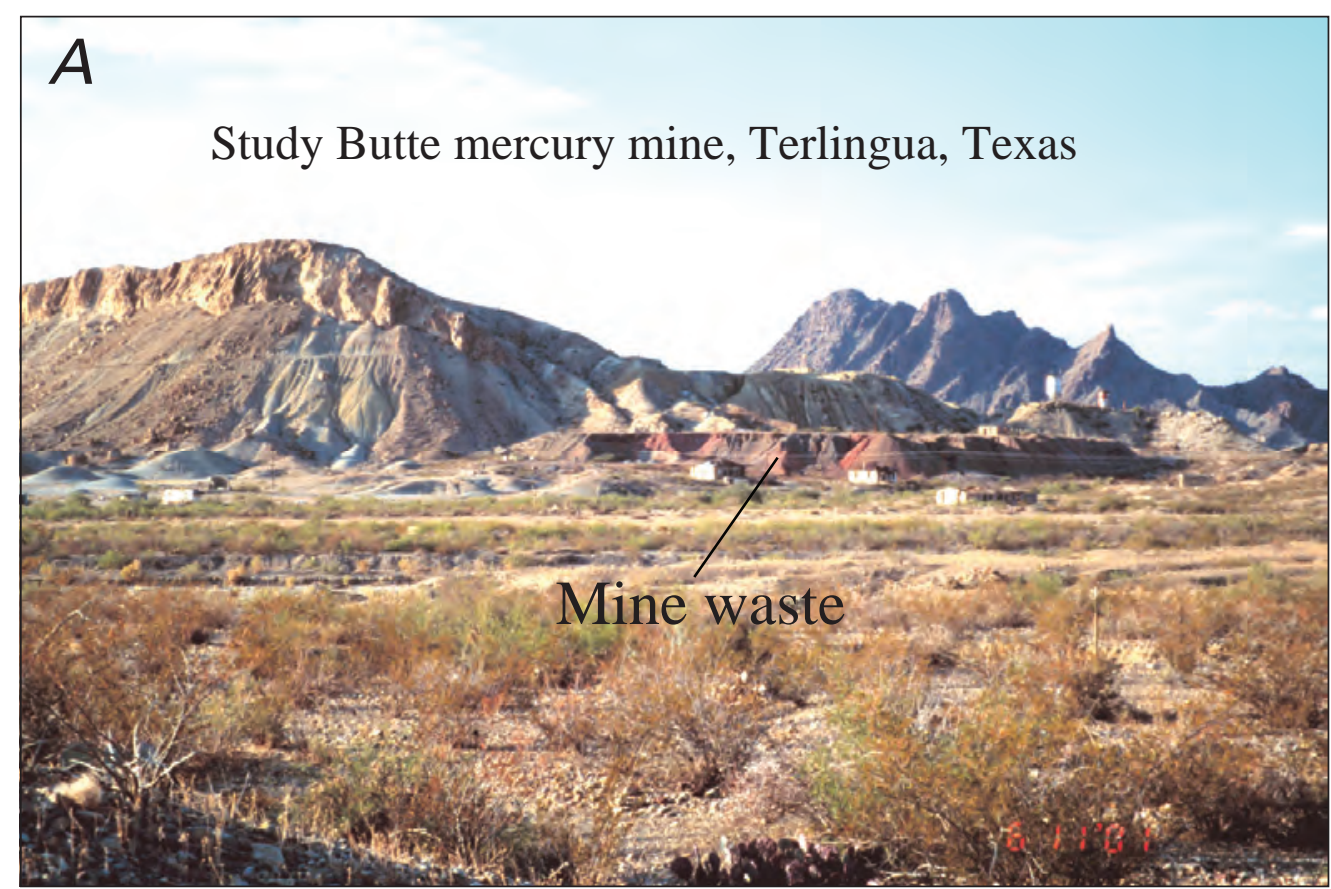

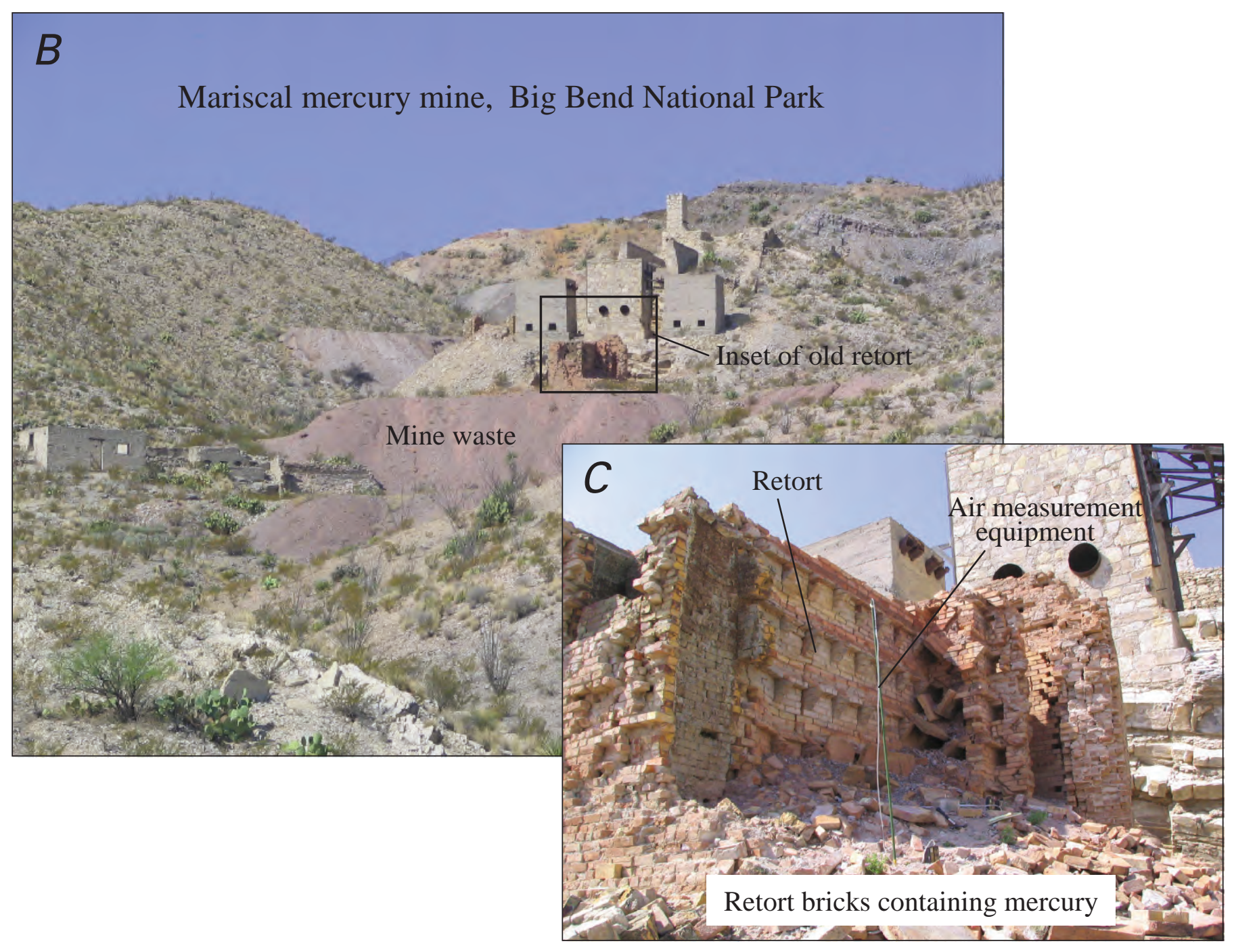




\section{$\square$ Mine waste $\quad \square$ Mine runoff sediment $\triangle$ Baseline sediment $\quad$ O Rio Grande}

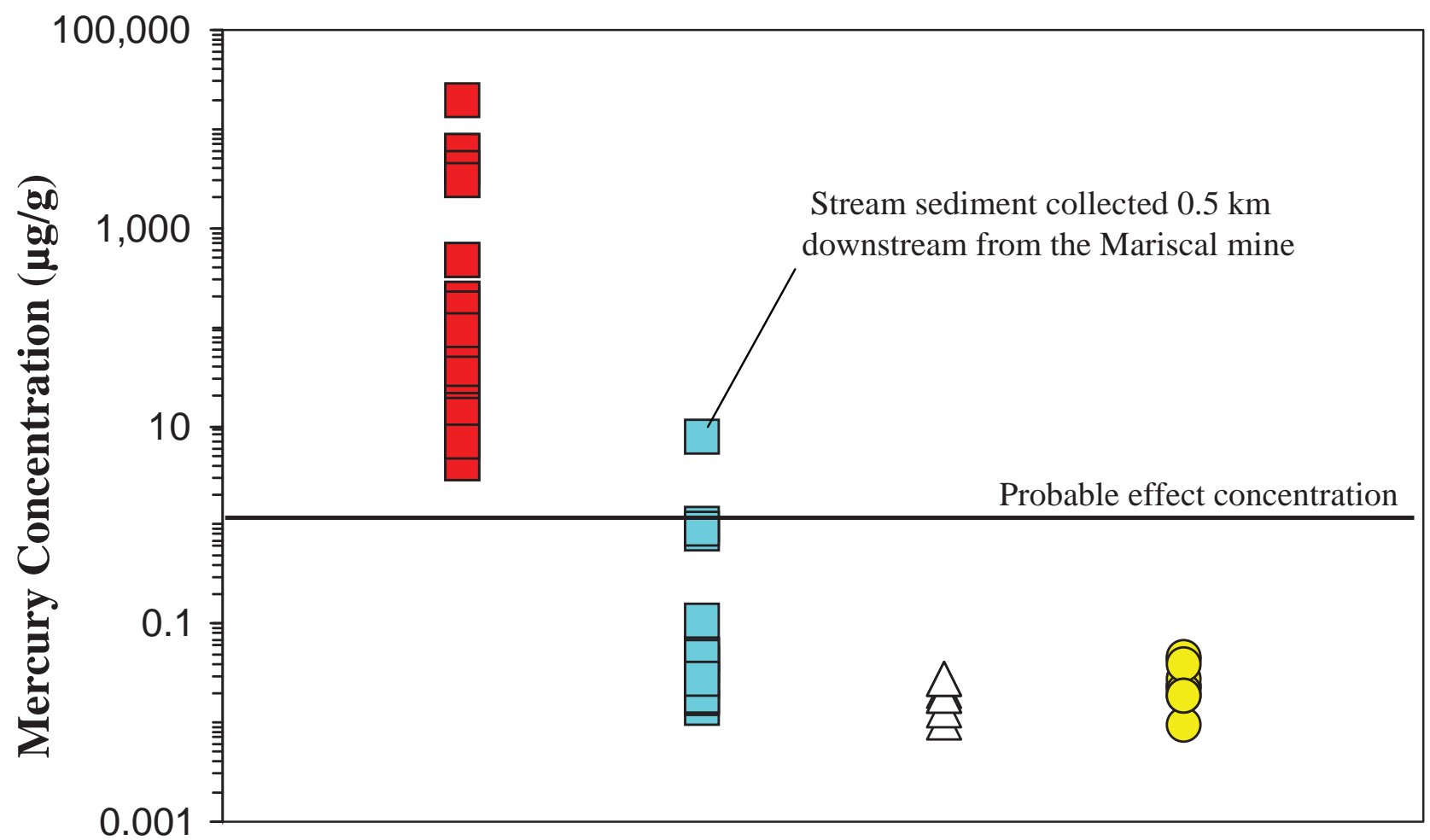

Figure 5-3. Concentration of mercury in mine waste and sediment collected in and around Big Bend National Park. The probable effect concentration of $1.06 \mu \mathrm{g} / \mathrm{g}$ in sediment is shown for reference and is the mercury concentration above which harmful effects are likely to be observed in sediment dwelling organisms (MacDonald and others, 2000). Only one stream sediment sample collected nearest the Mariscal mine contains mercury exceeding this probable effect concentration for mercury in sediment.

\section{Soil Gas and Air}

water samples collected in this study. Mercury concentrations found in all water samples collected in this study are significantly below the 2,000 $\mathrm{ng} / \mathrm{L}$ drinking water standard for mercury used in the United States (U.S. Environmental Protection Agency, 2003). Mercury concentrations in these water samples are also generally below the $12 \mathrm{ng} / \mathrm{L}$ mercury standard recommended by the EPA to protect against chronic effects to aquatic wildlife (U.S. Environmental Protection Agency, 1992). Only two water samples collected exceed the EPA aquatic life standard: (1) mine water runoff from the Terlingua mine that contained $14 \mathrm{ng} / \mathrm{L}$ mercury, and (2) Rio Grande water collected just outside of the western boundary of BBNP that contained $13 \mathrm{ng} / \mathrm{L}$. There are no water standards established for methylmercury concentrations in water; however, methylmercury concentrations in well and spring water, which are potential drinking water sources in BBNP, are similar to those reported for uncontaminated worldwide baselines (fig. 5-4) (Gray and others, 2004). With respect to mercury concentration, water quality in the samples collected in the Big Bend region is generally good where mercury concentrations are below acceptable EPA standards.
Mercury concentrations were measured in air and soil gas at the Mariscal mine in BBNP, as well as the Terlingua and Study Butte mines just outside of BBNP, to evaluate mercury emissions from mines in the Big Bend region. Concentrations of mercury emitted from mine waste at the Mariscal mine ranged from 690 to $1,400 \mathrm{ng} / \mathrm{m}^{3}$, and mercury emitted from mine waste at the Terlingua and Study Butte mine ranged from 720 to $1,600 \mathrm{ng} / \mathrm{m}^{3}$. However, concentrations of mercury emitted near an old brick Mariscal mine retort were higher and varied from 18,000 to $21,000 \mathrm{ng} / \mathrm{m}^{3}$ (figs. 5-2C and 5-5). Such mercury emissions reflect the presence of elemental mercury in mine waste and retort bricks. Mercury mine emission data indicate that the average flux of mercury emitted from the mines studied may exceed $2,000 \mathrm{ng} / \mathrm{m}^{2} / \mathrm{hr}$. Such mercury concentrations and mercury flux rates are high but are within the range of concentrations measured from other mercury mines worldwide (Ferrara and others, 1991; Gustin and others, 1996; Gray, 2003). In contrast, mercury concentrations in ambient air measured $2 \mathrm{~m}$ above the ground surface at these mercury mines ranged from 2.5 to $59 \mathrm{ng} / \mathrm{m}^{3}$, suggesting rapid atmospheric dispersion of mercury gas. Ambient air measured at $2 \mathrm{~m}$ 


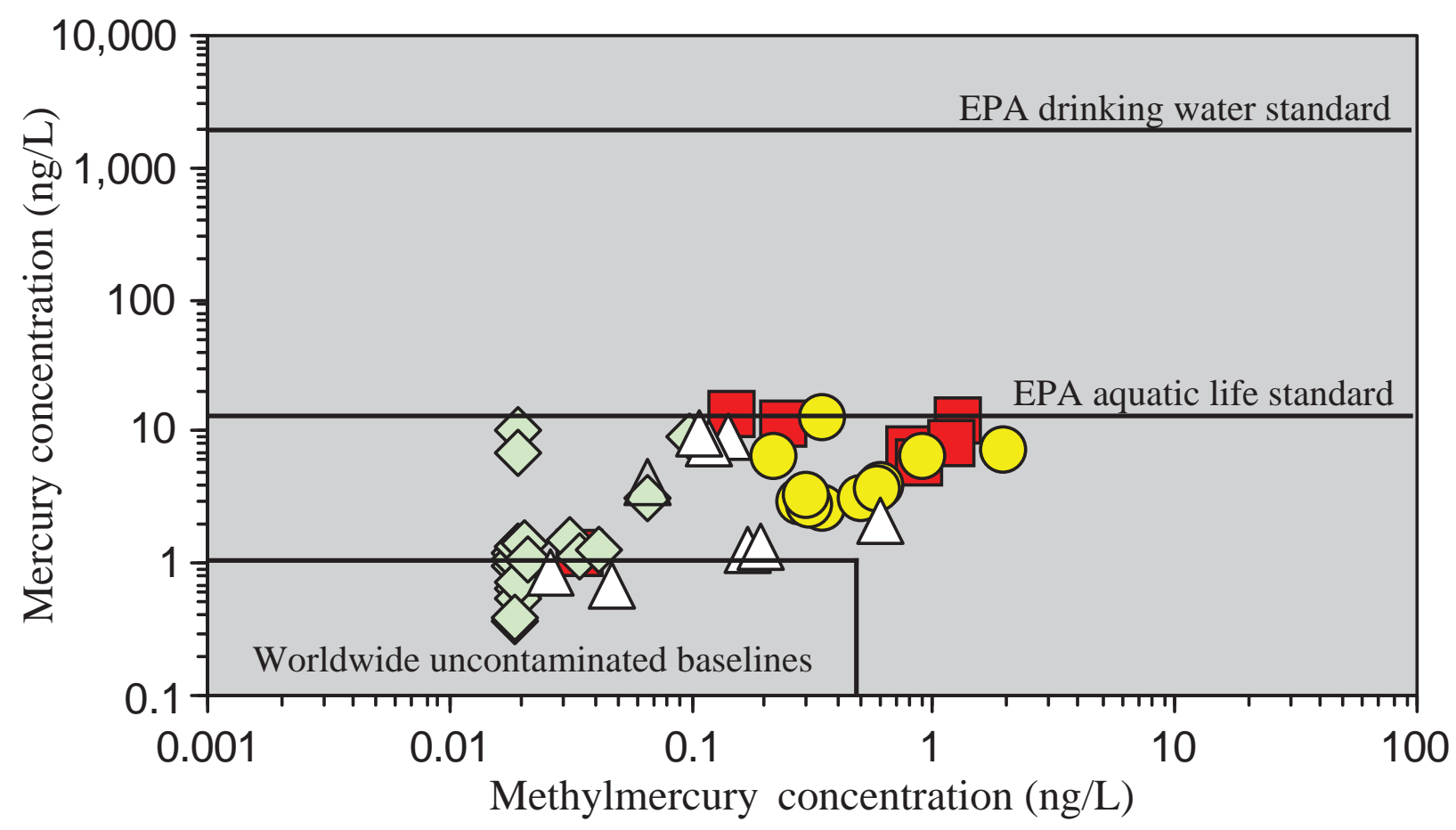

Figure 5-4. Concentration of mercury versus methylmercury in water collected in the Big Bend area. The EPA drinking water standard and the mercury standard to protect against adverse chronic effects to aquatic life are shown for reference. The range of data for worldwide uncontaminated baselines is also shown for reference.

above the surface at five baseline sites within BBNP contained mercury concentrations ranging from 1.2 to $17 \mathrm{ng} / \mathrm{m}^{3}$, similar to mercury found in the atmosphere worldwide, ranging from about 1 to $4 \mathrm{ng} / \mathrm{m}^{3}$ (Porcella, 1994; Lamborg and others, 2002). Soil at these baseline sites emitted mercury concentrations ranging from 2.6 to $71 \mathrm{ng} / \mathrm{m}^{3}$.

There are no mercury standards directly comparable to air and soil gas mercury data shown here, although the allowable mercury inhalation ceiling for the occupational health standard for workers in the United States is $100,000 \mathrm{ng} / \mathrm{m}^{3}$ (U.S. Occupational Safety and Health Administration, 1976); this mercury concentration cannot be exceeded at any time during the work day. Mercury concentrations measured in soil gas near the dilapidated brick retort at the Mariscal mine (fig. $5-2 C)$ were the highest observed in this study $\left(21,000 \mathrm{ng} / \mathrm{m}^{3}\right)$. These concentrations do not exceed the OSHA occupational standard, however, because these concentrations were measured in soil gas at the Mariscal mine retort area and are not directly analogous to the OSHA standard set for mercury concentrations inside of buildings. These results suggest that humans should not be exposed to mercury concentrations such as those found around the Mariscal mine retort for long periods of time, especially in closed spaces. People do not live near the Mariscal mine and there are no buildings located there for permanent or temporary occupation. The mercury emission data for the mines studied suggest that although concentrations of mercury in soil gas in mine waste are elevated, persistent wind in southwest Texas disperses mercury in air within a few meters of the ground surface. It is unlikely that tourists visiting mercury mines in the Big Bend region inhale enough mercury to make its presence a health concern. Furthermore, mercury concentrations found in air and soil gas at several baseline sites in BBNP suggest little regional influence of mercury emissions from these mines because the mercury concentrations from these baseline sites are similar to ambient air worldwide. 


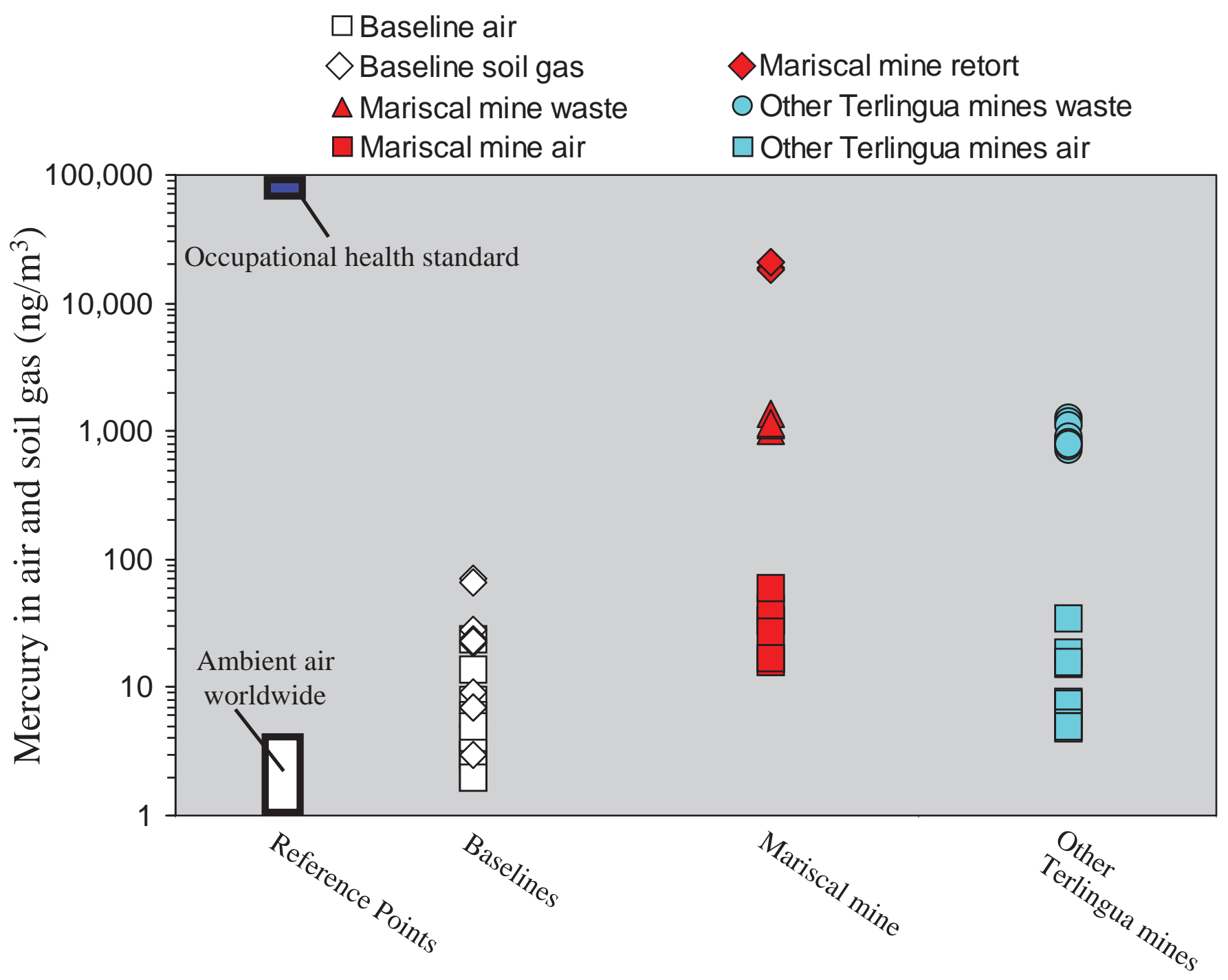

Figure 5-5. Mercury concentrations in air and soil gas collected from mercury mines in the Big Bend area and from uncontaminated baseline sites in the park. Concentrations of mercury in ambient air worldwide and the occupational health standard used in the United States are shown for reference.

\section{Conclusions}

Mercury was mined in the Big Bend region from about 1888 to 1973 and constituted an important mercury resource in the United States. Production exceeded 5,000 t of mercury, mostly from mines in and around the town of Terlingua, Tex.; one smaller mine, Mariscal, is located in BBNP. Although mercury and methylmercury concentrations in mine waste are locally elevated, there is only minor transference of mercury to surrounding ecosystems based on the mercury data for stream sediment and water samples collected downstream from the mines studied. Concentrations of mercury and methylmercury are generally low in stream sediment and water samples collected downstream from the mines studied, exhibiting significant mercury dispersion downstream. Low methylmercury concentrations in stream sediment and water indicate that the arid climate and lack of precipitation in the Chihuahuan Desert inhibit mercury methylation downstream, probably because methylating bacteria are dormant under such conditions. The Rio Grande is the most important ecosystem in the region, but mines in this region are distant from the Rio Grande ( $>10$ $\mathrm{km}$ ), and again, due to the lack of precipitation, mine runoff is minimal; when runoff is present, mercury is transported and significantly diluted before it reaches the Rio Grande. This lack of mining-related mercury influence in the Rio Grande is corroborated by the fact that mercury and methylmercury concentrations in Rio Grande sediment are similar to those found in regional baseline sediment samples (Gray and others, 2006). 


\section{References Cited}

Avery, D.W., Moyle, P.R., Reisenburg, R.M., and Fay, J.M., 1996, Preliminary assessment and site inspection, the Mariscal mine and mill site, Big Bend National Park, Brewster County, Texas: U.S. Bureau of Mines, Site Characterization Section special report.

Bailey, E.H., and Phoenix D.A., 1944, Quicksilver deposits in Nevada: Nevada Bureau of Mines and Geology Mining Series, v. 41, 206 p.

Ferrara, R., Maserti, B.E., Breder, R., 1991, Mercury in abiotic and biotic compartments of an area affected by a geochemical anomaly (Mt. Amiata, Italy): Water, Air, and Soil Pollution, v. 56, p. 219-233.

Gray, J.E., ed., 2003, Geologic studies of mercury by the U.S. Geological Survey: U.S. Geological Survey Circular 1248, $41 \mathrm{p}$.

Gray, J.E., Crock, J.G., Fey, D.L., 2002, Environmental geochemistry of abandoned mercury mines in West-central Nevada, USA: Applied Geochemistry, v. 17, p. 1,069-1,079.

Gray, J.E., Hines, M.E., and Biester, H., 2006, Mercury methylation influenced by areas of past mercury mining in the Terlingua district, southwest Texas, USA: Applied Geochemistry, v. 21, no. 11, p. 1,940-1,954.

Gray, J.E., Hines, M.E., Higueras, P.L., Adatto, I., and Lasorsa, B.K., 2004, Mercury speciation and microbial transformations in mine wastes, stream sediments, and surface waters at the Almadén mining district, Spain: Environmental Science and Technology, v. 38, p. 4,285-4,292.

Gustin, M.S., Taylor, G.E., Jr., Leonard, T.L., and Keislar, R.E., 1996, Atmospheric mercury concentrations associated with geologically and anthropogenically enriched sites in central western Nevada: Environmental Science and Technology, v. 30 , no. 8 , p. 2,572-2,579.

Kim, C.S., Bloom, N.S., Rytuba, J.J., and Brown, G.E., Jr., 2003, Mercury speciation by X-ray absorption fine structure spectroscopy and sequential chemical extractions-A comparison of speciation methods: Environmental Science and Technology, v. 37, p. 5,102-5,108.

Lamborg, C.H., Fitzgerald, W.F., O'Donnell, J., and Torgersen, T., 2002, A non-steady-state compartmental model of global-scale mercury biogeochemistry with interhemispheric atmospheric gradients: Geochimica et Cosmochimica Acta, v. 66, p. 1,105-1,118.

MacDonald, D.D., Ingersoll, C.G., and Berger, T.A., 2000, Development and evaluation of consensus-based sediment quality guidelines for freshwater ecosystems: Archives of Environmental Contamination and Toxicology, v. 39, p. 20-31.
Porcella, D.B., 1994, Mercury in the environment-Biochemistry, in Watras, C.J., and Huckabee, J.W., eds., Mercury pollution, integration and synthesis: Boca Raton, Fla., CRC Press, p. 3-19.

Ross, C.P., 1941, The quicksilver deposits of the Terlingua region, Texas: Economic Geology, v. 35, p. 115-142.

Rytuba, J.J., 2000, Mercury mine drainage and processes that control its environmental impact: Science of the Total Environment, v. 260, p. 57-71.

Sharp, R.D., 1980, Development of the mercury mining industry-Trans-Pecos Texas: University of Texas at Austin, Bureau Economic Geology Mineral Resource Circular 64, $32 \mathrm{p}$.

Sznopek, J.L., and Goonan, T.G., 2000, The materials flow of mercury in the economies of the United States and the world: U.S. Geological Survey Circular 1197, 28 p.

Ullrich, S.M., Tanton, T.W., and Abdrashitova, S.A., 2001, Mercury in the aquatic environment-A review of factors affecting methylation: Critical Reviews Environmental Science and Technology, v. 31, no. 3, p. 241-293.

U.S. Environmental Protection Agency, 1992, Water quality standards; establishment of numeric criteria for priority toxic pollutants; states' compliance; final rule: Federal Register, Title 40, Part 131, 57/246, p. 60,847-60,916.

U.S. Environmental Protection Agency, 2003, National primary drinking water standards: U.S. Environmental Protection Agency, Office of Ground Water and Drinking Water, EPA 816-F-03-016, http://www.epa.gov/safewater/contaminants/index.html, accessed 1 August 2008.

U.S. Occupational Safety and Health Administration, 1976, Mercury OSHA standards: U.S. Department of Labor, http://www.osha.gov/SLTC/mercury/standards.html, accessed 11 March 2008. 


\title{
6. The Waters of Big Bend: Geochemical Variations, Ages, and Sources
}

\author{
By W.C. Pat Shanks III, Lisa A. Morgan, John E. Gray, Andrew H. Manning, and Pamela A. Gemery-Hill
}

\section{Abstract}

Geochemical studies show a variety of different types of water in Big Bend National Park. Rainfall recharges ground water aquifers that supply wells and springs that constitute significant drinking water supplies at The Basin, the Headquarters area, Rio Grande Village, and the Castolon area. Panther Junction, K-Bar, and Oak Spring produce water that is dilute relative to surface water and hot spring water. Heliumtritium studies show these are mixed waters with old ( $>50 \mathrm{yr}$ ) and young components. Noble gas concentrations indicate that Oak Spring water is recharged above 1,600 m altitude, probably on Ward Mountain.

Hot springs in the Rio Grande Village (RGV) area are mostly old water that has much higher concentrations of dissolved solids resulting from subsurface reaction with limestone at moderately high temperatures $\left(130-180^{\circ} \mathrm{C}\right)$. Hot spring water is notably enriched in arsenic and lithium relative to other water in the park. Noble gas concentrations indicate that such water is recharged at an altitude of at least $900 \mathrm{~m}$. Likely recharge areas are $5 \mathrm{~km}$ north of RGV in Cretaceous Santa Elena Limestone or $15 \mathrm{~km}$ to the south in similar rocks in Mexico. Fluid flow is along fault zones and deep circulation allows heating along the geothermal gradient.

Water in the Castolon area is produced from wells near Cottonwood campground and generally has the highest dissolved solids of any ground water in the Park. Such water is young $(0-5 \mathrm{yr})$ and has chemical similarities to, but is more concentrated than, modern Rio Grande water. Most likely, Cottonwood water has dissolved soluble sodium, calcium, chloride, and sulfate salts that are stored in river alluvium from past evaporation events. Enriched concentrations of arsenic and lithium in the Cottonwood water may also come from soluble salts or may be a result of mixing with cooled geothermal water.

\section{Introduction}

Big Bend National Park (BBNP) encompasses 800,000 acres with altitudes from approximately $1,800 \mathrm{ft}(550 \mathrm{~m})$ along the Rio Grande to 7,800 $\mathrm{ft}(2,380 \mathrm{~m})$ in the Chisos Mountains. This includes environments ranging from extremely arid
Chihuahuan low desert with mesquite-lechuguilla-creosotecactus-sotol habitats to montane islands of pinyon-juniper-oak woodland, and cypress-pine-oak associations (Hellgren, 1993). Annual precipitation averages $30.5 \mathrm{~cm}$, with most falling during thunderstorms in July, August, and September. Rainfall accumulations generally increase with elevation in the park, as indicated by average annual precipitation of about $25 \mathrm{~cm}$ at $\mathrm{RGV}$ and about $50 \mathrm{~cm}$ in The Basin.

In the arid climate of BBNP, water quality and water supply are persistent issues. Geochemical data reported here are designed to evaluate sources, transport, residence time, and dispersion of metals and other constituents in surface water, ground water, and active hot springs. Determination of chemical and isotopic compositions of water provides baselines against which future trends related to climate change, drought, and other regional events can be compared. Water samples were collected from a broad range of geologic and geographic settings in BBNP including: hot springs near RGV, nonthermal springs throughout the park, water supply wells, and water from the Rio Grande and other streams (fig. 6-1).

Chemical compositions (major elements, trace elements, and noble gases), stable isotopes (hydrogen and oxygen), and radiogenic isotopic compositions (helium and tritium) have been analyzed using established geochemical procedures at the U.S. Geological Survey (USGS) laboratories in Denver, Colo. (Epstein and Mayeda, 1953; Kendall and Coplen, 1985; Aeschbach-Hertig and others, 1999; Solomon and Cook, 2000; Hageman, 2002; Lamothe and others, 2002; Theodorakos, 2002).

The geologic setting of BBNP (fig. 6-1) controls ground water flow paths through permeable units or along fault zones. Subsurface reactions with rocks and sediments and soluble salts determine water composition. In simplest terms, geologic units in BBNP include stream and alluvial fan deposits of mud, sand, and gravel of Holocene to Miocene age; felsic to mafic igneous rocks, including dikes, sills, laccoliths, stocks, lava flows, and pyroclastic flow and fall deposits; and Cretaceous limestone, sandstone, and shale units (fig. 6-1). Recent stream deposits, fractured igneous rocks, permeable sandstone layers, and fractured and faulted limestone units are the most important aquifers in BBNP (Baker and Buszka, 1993). 


\section{Big Bend Water Samples}

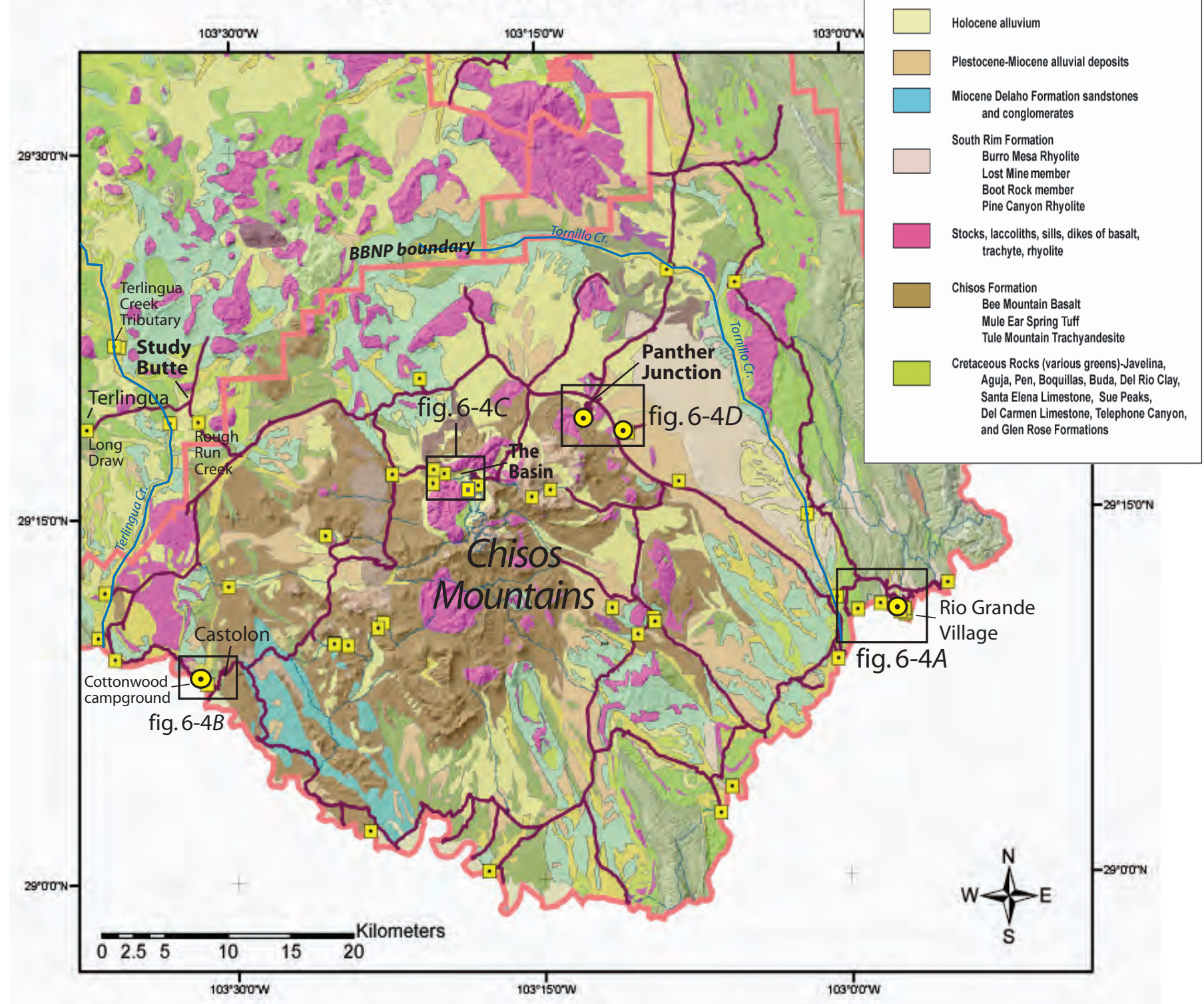

Figure 6-1. Location of Big Bend water samples from springs, streams, and drinking water wells. Surface and spring water samples (yellow squares) and well waters (yellow circles) were collected in and around Big Bend National Park. Geology from Maxwell and others (1967). Locations of detailed maps shown in figure 6-4 are shown by open boxes. 


\section{General Characteristics of Big Bend Water}

Oxygen and hydrogen stable isotope data indicate that all water samples from Big Bend are of meteoric origin (have participated in an atmospheric cycle) and generally enter the surface and subsurface water cycle as rainfall. The isotopes, $\delta^{18} \mathrm{O}$ and $\delta \mathrm{D}$, of stream water samples (fig. 6-2) follow the Global Meteoric Water Line (Craig, 1961). Thermal water and spring water samples are shifted to slightly higher values because of water-rock reactions in the subsurface or evaporation at the surface. Many spring water samples, collected in winter or spring, are from pools in alluvial drainages that show little evidence of flow and thus are subject to surface evaporation.

Chemical data shows that ground water generally has the lowest total dissolved solids in BBNP, consistent with fresh rainfall reacting at low temperatures with alluvium, limestones, sandstones, and igneous rocks. Hot spring water and Rio Grande water samples contain significantly more dissolved solids, and each has characteristic compositional ranges.

Variation plots (fig. 6-3) of major constituents (sodium, potassium, calcium, magnesium, sulfate, and chloride) and selected trace elements (arsenic, lithium, and strontium) show that there are significant differences among water types in BBNP. Stream water samples (fig. 6-3A) have the largest range of chemical composition; factors that affect this range are surface evaporation, dissolution of salt crusts, and agricultural irrigation runoff. Water samples from the Rio Grande and hot spring water samples (fig. 6-3B) are distinctly higher in total dissolved concentrations than Oak Spring and The Basin area waters (fig. 6-3C) or waters from the Panther Junction and K-Bar wells (fig. 6-3D).

In addition to chemical data and stable isotope data, radiogenic isotopes and noble gases have been analyzed to provide information about the age and conditions of recharge of ground water systems. Tritium $\left({ }^{3} \mathrm{H}\right)$ is a radioactive isotope of hydrogen produced during atmospheric nuclear bomb testing in the 1950s and 1960s. Tritium enters ground water by infiltration of precipitation and then decays with time into another isotope, helium-3 ( $\left.{ }^{3} \mathrm{He}\right)$. Because the rate of radioactive decay is known (tritium half-life $=12.43 \mathrm{yr}$ ), tritium and helium-3 can be used to date ground water younger than about $50 \mathrm{yr}$, as well as to determine the approximate fractions of old water ( $>50 \mathrm{yr}$ old $)$ and young water $(<50 \mathrm{yr}$ old $)$ in mixed age samples.

Helium-tritium data for Big Bend water (table 6-1) indicate that most ground water utilized as drinking water is a mixture of young water and an older, more deeply circulating water. In particular, K-Bar well water is composed mainly of old water ( $>50 \mathrm{yr}$ ) and Oak Spring, RGV, and Panther Junction (fig. 6-1) are mixed waters, with important components of both old and young water. Cottonwood well water, which supplies Castolon and Cottonwood campground (fig. 6-1), is mainly young water. Noble gas data indicate that aquifers that supply Oak Spring and RGV wells are recharged at elevations significantly higher than the elevation where the water is collected.

\section{River and Stream Water}

The water of the northern Rio Grande is derived from runoff in the mountainous regions of southern Colorado and northern New Mexico, but most of the water is lost to irrigation use, evaporation, and infiltration by the time the river reaches Texas. South of El Paso, the river is dry during many years, and more than 75 percent of the water in the Rio Grande at BBNP is derived from the Rio Conchos, which drains $77,000 \mathrm{~km}^{2}$ in northern Mexico and joins the Rio Grande at Ojinaga, just north of Presidio. The Rio Conchos carries significant dissolved solids resulting from evaporation, irrigation runoff, fertilizers and pesticides, and wastewater (Gutierrez and Borrego, 1999).

Most other streams in BBNP are ephemeral, but Terlingua Creek and Tornillo Creek have significant stretches of perennial flow. Chemical data (fig. 6-3A) show that perennial streams have lower total dissolved solids. Terlingua Creek waters are similar to typical ground waters (fig. 6-3C, D). Ephemeral streams (Long Draw, Rough Run, and a northern tributary of Terlingua Creek) can have very high concentrations attributed to evaporation in drainages or to dissolution of previously deposited salts like calcium sulfate. The Rio Grande dissolved solids generally are higher than perennial streams like Terlingua Creek or Big Bend ground waters (fig. 6-3A).

\section{Hot Spring Waters}

Hot springs in BBNP are located along the Rio Grande river valley, especially near RGV (figs. 6-1 and 6-4A). Hot springs have temperatures up to $40.1^{\circ} \mathrm{C}$ and are enriched in major constituents (sodium, potassium, calcium, magnesium, sulfate, and chloride) and some trace elements (arsenic, lithium, rubidium, strontium, thallium, uranium, and tungsten) relative to nonthermal springs. Potentially toxic trace metals in thermal waters have concentration ranges as follows: arsenic $(6.2-13.8 \mu \mathrm{g} / \mathrm{L})$, mercury $(1.3-10 \mu \mathrm{g} / \mathrm{L})$, thallium $(0.13-0.68 \mu \mathrm{g} / \mathrm{L})$, tungsten (to 7.0 $\mu \mathrm{g} / \mathrm{L})$, and uranium $(7.0-8.4 \mu \mathrm{g} / \mathrm{L})$. All of these concentrations are below drinking water limits (where established), except for arsenic in Langford hot spring, which exceeds the Environmental Protection Agency limit for drinking water of $10 \mu \mathrm{g} / \mathrm{L}$ (U.S. Environmental Protection Agency, 2007). Langford hot spring water, however, is not used for drinking, and water samples analyzed in this study from wells at RGV do not exceed the limit.

Helium-tritium and noble gas data for hot spring water samples collected in a production well that supplies drinking water for RGV (fig. 6-4A) indicate a large component of old water and relatively warm recharge temperatures (table 6-1). They are geothermally heated during deep circulation along major fault zones. Chemical geothermometer calculations indicate they probably reach temperatures of $130-180^{\circ} \mathrm{C}$ along their flow path.

Noble gas data indicate that recharge to the aquifer carrying $\mathrm{RGV}$ thermal water probably occurrs at altitudes greater than $900 \mathrm{~m}$ (table 6-1). The closest area with this altitude, and 


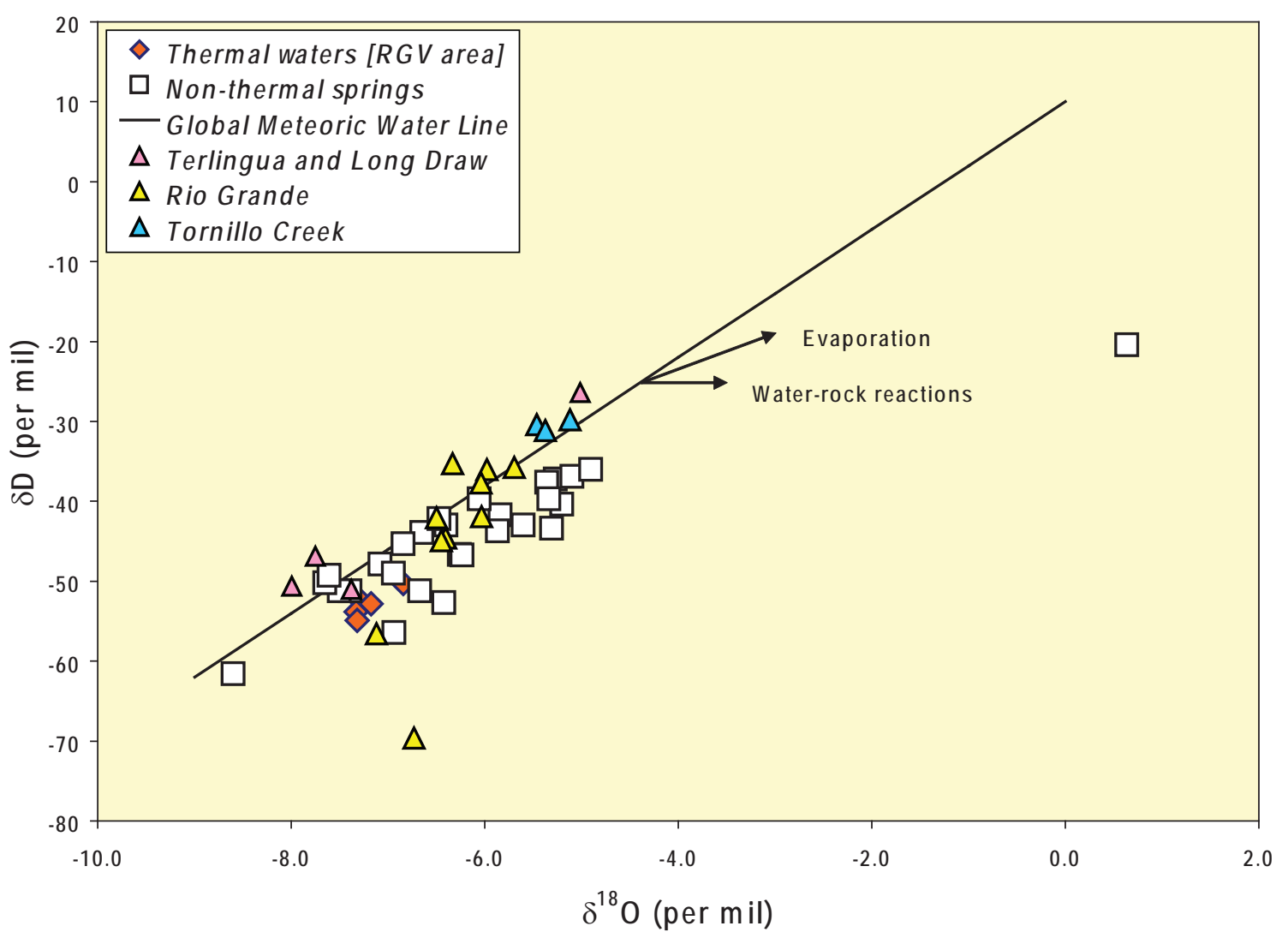

Figure 6-2. Oxygen and hydrogen composition of Big Bend waters. All waters are meteoric (rainfall or snow derived). Shifts off the Global Meteoric Water Line (Craig, 1961) are due to evaporation or water-rock reaction. RGV, Rio Grande Valley.

Figure 6-3 (facing page). Chemical variation diagrams for selected constituents that illustrate fundamental differences between waters from different areas. $A$, Stream water samples from the Big Bend area. The Rio Grande, Tornillo Creek, and Terlingua Creek are perennial streams. Long Draw, Rough Run, and the tributary of Terlingua Creek (fig. 6-1) are ephemeral streams, and their compositions are strongly affected by evaporation or dissolution of evaporative salts. Terlingua Creek is compositionally similar to many ground water samples from springs and wells. Inset: Photo of ephemeral stream bed with Ward Mountain in the background. $B$, Rio Grande, hot spring, and Cottonwood campground water samples are significantly more enriched in most constituents (see text for discussion). Note that the composition of $\mathrm{Na}$ in Cottonwood water samples is estimated because they exceeded the calibrated range during ICP-MS analyses. Inset: Photograph of Langford hot spring along the bank of the Rio Grande, located a few km west of Rio Grande Village. $C$, Water samples from La Paloma spring in The Basin, The Window spring, and Oak Spring are relatively dilute and are very similar in composition, except for significant variation in $\mathrm{Ca}$ and $\mathrm{SO}_{4}$. La Paloma water flows into pools along an incised bedrock drainage where evaporation during dry periods would cause deposition of calcite and gypsum. Gypsum may redissolve during wetter periods. Dilution occurs along the flow path to 0 ak Spring (indicated by yellow arrows in figure 6-4C). Inset: Photograph of The Window. $D$, Water from Panther Junction and $\mathrm{K}$-Bar wells are dilute $\mathrm{Na}-\mathrm{Cl}-\mathrm{Ca}-\mathrm{SO}_{4^{\prime}}$, like many ground water samples in the park. 

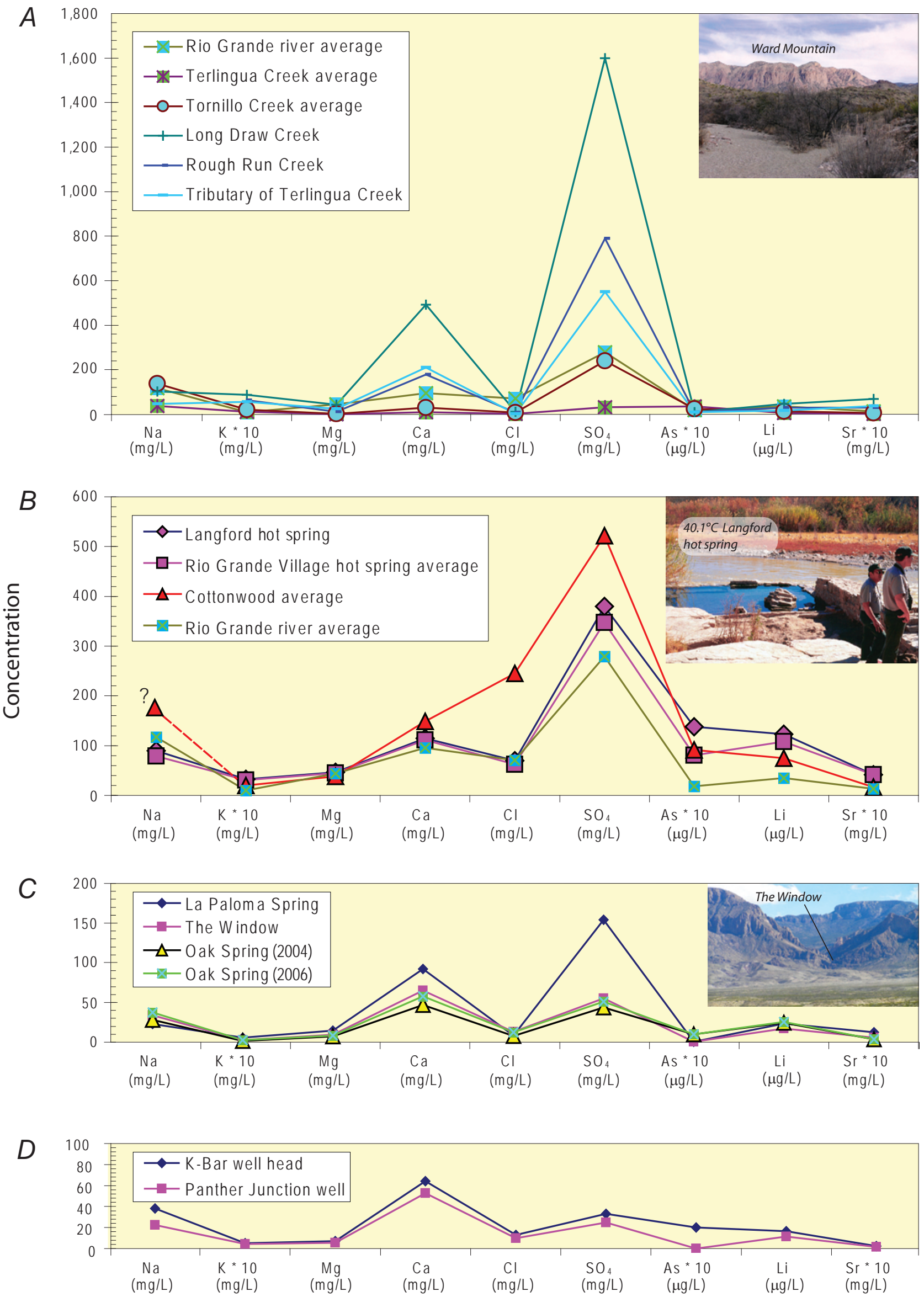
Table 6-1. Helium-tritium and rare gas results.

\begin{tabular}{|c|c|c|c|c|c|}
\hline Sample site & Site type & $\begin{array}{l}\text { Apparent } \\
\text { age' }^{1}(y r)\end{array}$ & $\begin{array}{c}\text { Tritium } \\
(\mathrm{TU})^{2}\end{array}$ & $\begin{array}{l}\text { Initial } \\
\text { tritium } \\
\text { (TU) }\end{array}$ & Interpretation of results \\
\hline $\begin{array}{l}\text { K-Bar well head } \\
\text { (BB-06-370) }\end{array}$ & $\begin{array}{l}\text { production } \\
\text { water well }\end{array}$ & 0.0 & 0.66 & 0.66 & $\begin{array}{l}\text { Mostly pre-nuclear bomb testing. }>80 \% \text { over } 50 \mathrm{yr} \text { old. } \\
\text { Age of modern component uncertain. }\end{array}$ \\
\hline $\begin{array}{l}\text { Cottonwood well } \\
\quad \# 1 \\
\text { (BB-06-380) }\end{array}$ & $\begin{array}{l}\text { production } \\
\text { water well }\end{array}$ & 5.2 & 3.43 & 4.60 & $\begin{array}{l}\text { Mostly modern. Modern component } 0-5 \mathrm{yr} \text { old. Cool } \\
\text { recharge temperature consistent with Rio Grande water. }\end{array}$ \\
\hline $\begin{array}{l}\text { Rio Grande Village } \\
\text { water system } \\
\text { well head } \\
\text { (BB-06-383) }\end{array}$ & $\begin{array}{l}\text { production } \\
\text { water well }\end{array}$ & $>50$ & 0.11 & 4.11 & $\begin{array}{l}\text { Pre-bomb. Requires recharge elevation }>900 \mathrm{~m}(<10 \% \\
\text { probability of recharge elevation }<900 \mathrm{~m}) \text { and deep wa- } \\
\text { ter table (warm recharge temperature). High }{ }^{3} \mathrm{He} \text { values } \\
\text { indicate a mantle component. }\end{array}$ \\
\hline $\begin{array}{l}\text { Panther Junction } \\
\text { water system } \\
\text { from building } \\
\text { (BB-06-384) }\end{array}$ & $\begin{array}{l}\text { production } \\
\text { water well }\end{array}$ & 27.8 & 2.77 & 13.24 & $\begin{array}{l}\text { Mixed water. Apparent age of young component could be } \\
0-28 \text { yr. }\end{array}$ \\
\hline $\begin{array}{l}\text { Oak Spring } \\
\text { (BB-06-400) }\end{array}$ & mixing box & 0.0 & 1.30 & 1.30 & $\begin{array}{l}\text { Mixed water. }>60 \% \text { over } 50 \mathrm{yr} \text { old. Age of modern com- } \\
\text { ponent uncertain. Requires recharge elevation }>1,900 \\
\mathrm{~m}(<10 \% \text { probability of recharge elevation }<1,900 \mathrm{~m}) \\
\text { and shallow water table (cool recharge temperature). }\end{array}$ \\
\hline
\end{tabular}

${ }^{1}$ For mixed waters, the apparent age is the approximate age of the modern water component.

${ }^{2} \mathrm{TU}$ is a tritium unit, defined as one tritium-bearing water molecule in $1,018 \mathrm{H}_{2} \mathrm{O}$ molecules. 
thus the most probable recharge area, is about $5 \mathrm{~km}$ north of RGV in the Cretaceous Santa Elena Limestone. A potential ground-water flow path from this recharge area is along N-S trending faults (fig. 6-4A). Another potential recharge area with elevations $>900 \mathrm{~m}$ is in Mexico about $15 \mathrm{~km}$ south of the hot springs. The geology to the south is also dominated by Cretaceous limestone that is similarly faulted, although mapping there shows no major structure directly south of the Langford hot spring site (fig. 6-4A).

\section{Castolon and Cottonwood Campground Water}

Helium-tritium analyses for waters from the Cottonwood water-supply well show that the well produces young water $(0-5 \mathrm{yr})$ with cool recharge temperatures. This result is reasonable for a geologic setting in alluvial deposits adjacent to the Rio Grande (fig. 6-4B) and suggests that modern Rio Grande water is the dominant component in the Castolon and Cottonwood water supply.

Cottonwood water samples (fig. 6-3B) have substantially higher concentrations of all elements than the typical ground water samples collected from Panther Junction, K-Bar, and Oak Spring. Moreover, chemical data (fig. 6-3B) show that Cottonwood water samples are significantly enriched in sodium, calcium, chloride, sulfate, arsenic, lithium, and strontium relative to Rio Grande water.
The potassium, lithium, and arsenic concentrations in Cottonwood water samples are intermediate between Rio Grande water and hot spring waters at RGV (fig. 6-3B). It is possible that Cottonwood waters have mixed with a cooled component of thermal water to produce the unusual enrichments in these elements. Thermal springs are not known to be in the Castolon area, but they are found to the north in the Presidio area and, of course, to the south in the RGV area. A thermal water component, however, cannot explain the enrichments in sodium, calcium, chloride, and sulfate (fig. 6-3B), so an additional or different source is required.

A likely source of sodium, calcium, chloride, and sulfate for Cottonwood water is the dissolution of salts deposited by evaporation after flood events or during periods of drought when river levels are especially low. Howari (2002) found three types of salt crusts in soil along the Rio Grande: hydrated calcium sulfate, sodium sulfate, and sodium chloride. These salt crusts form through evaporation of Rio Grande water and are redissolved during flood events. Over time, soluble salts would be buried in Rio Grande alluvium and might be redissolved by flowing ground water like that pumped from the Cottonwood wells.

Dissolution of soluble salts into modern Rio Grande water is the best explanation for the major element chemistry of Cottonwood water, but it is not clear if this process can also provide the high arsenic and lithium. Further investigation of the trace metal composition of soluble salts is needed to resolve this issue.

Figure 6-4 (following 2 pages). Geologic setting of drinking water production sites in Big Bend National Park. See figure 6-1 for locations of these subarea maps. Turquoise square symbols indicate water samples. Geologic units are: Qal, Quaternary alluvium; 0 co, Quaternary colluvium; QTog, Quaternary to Tertiary older gravels; Tacb, Tertiary Alamo Creek Basalt; Tasb, Tertiary Ash Springs Basalt; Tig, Tertiary igneous rocks; Tch, Tertiary Chisos Formation; Tcf, Tertiary Canoe Formation; Tbmb, Tertiary Bee Mountain Basalt; Tbr, Tertiary Brown Rhyolite; Twsf, Tertiary Wasp Spring Flow Breccia; Kag, Cretaceous Aguja Formation; Kp, Cretaceous Pen Formation; Kbo, Cretaceous Boquillas Formation; Kbu, Cretaceous Buda Formation; Kse, Cretaceous Santa Elena Formation; Kdr, Cretaceous Del Rio Formation; Kdc, Cretaceous del Carmen Formation; Ksp, Cretaceous Sue Peak Formation; Kjf, Cretaceous Javelina Formation. Big Bend National Park geology from Maxwell and others (1967). Mexican geologic mapping from Servicio Geológico Mexicano (2003). $A$, Geologic and shaded relief map of the Rio Grande Village (RGV) area. Note location of Langford hot spring, west of RGV, the hottest thermal water spring in the Park at $40.1^{\circ} \mathrm{C}$. Water samples at Rio Grande Village are all thermal waters similar in composition, but somewhat more diluted than Langford waters. Hot spring water is probably recharged about $5 \mathrm{~km}$ north of RGV in higher ground of the Cretaceous Santa Elena limestones and flows along N-S fault zones (yellow arrows) to the hot spring sites. Possible recharge sites to the south in Mexico also are shown. Mine symbols (crossed picks) indicate fluorite mines. $B$, Castolon area geology with location of water samples near Cottonwood campground. Castolon water is young water from Rio Grande alluvium. $C$, Geology and topography of The Basin area. The Basin water supply is at Oak Spring, which is a mixed water with young components recharged near Oak Spring and older (>50 yrs) waters sourced in the high Chisos Mountains, probably near Ward Mountain and LaPaloma spring (see text for discussion). Yellow arrows indicate probable flow path of waters that recharge Oak Spring. D, Geology and shaded relief map of the Panther Junction and K-Bar areas where important water production wells produce water from tuffaceous sandstones of the Tertiary Chisos Formation. 

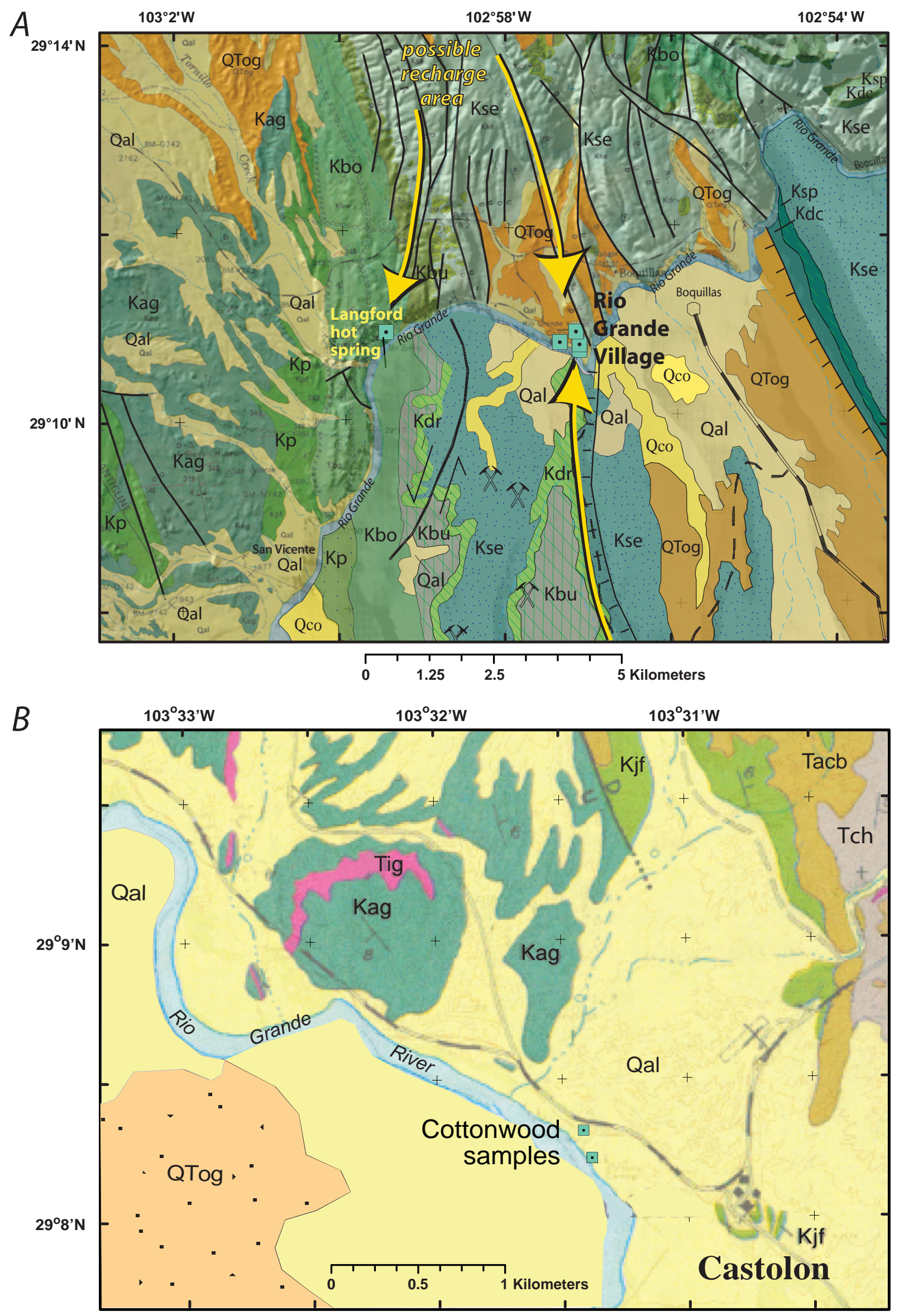

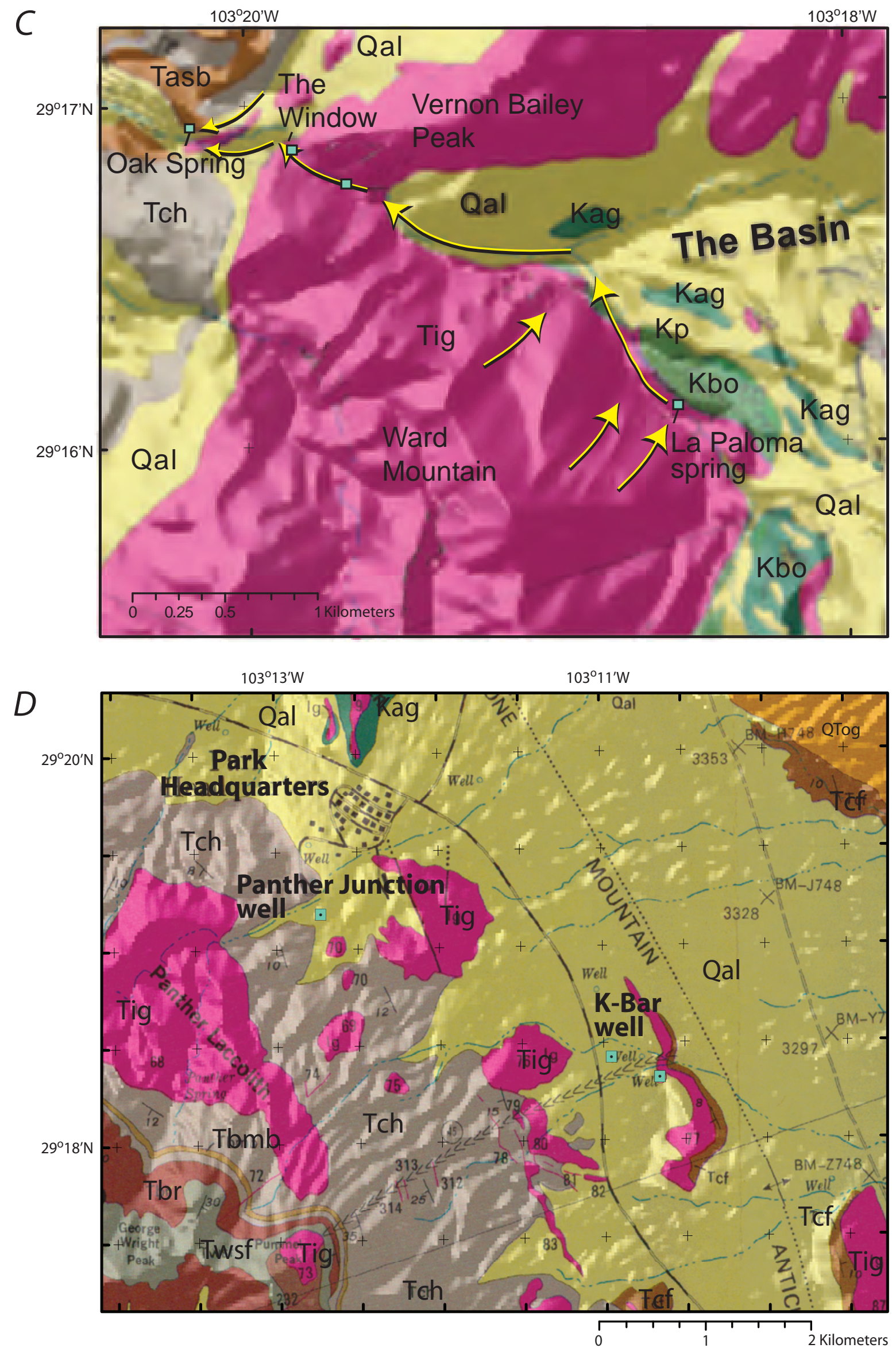


\section{Source of the Basin Water Supply}

The water supply for The Basin is at Oak Spring near the base of the Chisos Mountains, directly below The Window (figs. 6-1 and 6-4C). Helium-tritium data indicate that Oak Spring has mixed waters that contain approximately 60 percent old water (that is, water greater than $50 \mathrm{yr}$ old). Noble gas data indicate that water in Oak Spring is recharged at an altitude above 1,900 $\mathrm{m}$, which means it recharges in the high Chisos Mountains, most likely on Ward Mountain. Large areas of Ward Mountain are above 1,900 $\mathrm{m}$ in elevation and have drainage gradients toward La Paloma spring (fig. 6-4C), which is on the main drainage to The Window. Baker and Buszka (1993) used test drilling and seismic reflection data to show that the subsurface aquifer that locally supplies Oak Spring is a confined $1.5-\mathrm{m}$-thick sand bed. They concluded that most recharge occurs below The Window within approximately $500 \mathrm{~m}$ of Oak Spring; however, they also discussed the possibility of some of the recharge coming from the mountains above through fractures in the igneous rocks that underlie The Window.

Our new data suggest that a substantial portion of the recharge comes from high elevations in the Chisos Mountains, probably from the Ward Mountain area, with subsequent flow along the drainage occupied by La Paloma spring (fig. 6-4C) and into the subsurface along fractures (fig. 6-5) to the topographically lower Oak Spring. Flow pathways to Oak Spring could vary with time, meaning that the primary recharge area for Oak Spring water may vary seasonally.

The Basin area is underlain by rhyolitic intrusive bodies and limestone units, yet the water is similar to Panther Junction and K-Bar well water (fig. 6-3D). The main difference is a somewhat higher calcium and sulfate content in The Basin/ Oak Spring water. Geochemical similarities between water samples from LaPaloma spring on the flank of Ward Mountain and water samples from The Window spring downstream and Oak Spring below The Window pouroff (fig. 6-3C) indicate that such water is probably related and that the main compositional changes are due to salt dissolution followed by dilution along the flow path. Both The Window spring and La Paloma spring are in bedrock drainages where water may evaporate and precipitate minerals during dry periods. Geochemical calculations of evaporative removal of water indicate that calcium carbonate (calcite) deposition predominates, but calcium sulfate (gypsum) is deposited during dry periods. Later, during wet periods, these minerals may redissolve. Gypsum is much more soluble than calcite and hence the $\mathrm{Ca}$ and $\mathrm{SO}_{4}$ content of the water is strongly affected by salt dissolution. Because of salt dissolution, our La Paloma sample has higher initial values of these constituents, and dilution along the flow path leads to less concentrated water at Oak Spring.

This interpretation is consistent with the helium-tritium and noble gas solubility data that indicate young and old water components. The older component is recharged in the Chisos Mountains and the younger component is recharged in alluvium or in sedimentary deposits near Oak Spring.

\section{Panther Junction and K-Bar Drinking Water Wells}

Water from production wells at Panther Junction and $\mathrm{K}$-Bar (fig. 6-4D) is produced from subsurface aquifers in tuffaceous sandstone of the Tertiary Chisos Formation (Abbott, 1983; Gibson, 1983); this water has reacted mainly with rhyolitic ash. Helium-tritium data indicate that K-Bar water is mostly older than 50 yrs and Panther Junction water is mixed water with roughly equal proportions of old water and young water. Panther Junction and K-Bar waters have some of the lowest dissolved solids in BBNP and are sources of good quality water.

\section{Conclusion}

Water samples collected from BBNP show a large range of chemical compositions and complex histories of subsurface flow and reaction. Helium-tritium data show that most drinking water sources in BBNP are mixed waters with both young and older components. Exceptions are K-Bar water, which predates nuclear bomb testing ( $>50 \mathrm{yr}$ ), and Cottonwood well water, which is mostly young (0-5 yr). Noble gas solubility calculations show that RGV well water and Oak Spring water are recharged at higher elevations in surrounding mountains. Hot spring water found at RGV has a relatively long residence time during subsurface flow and is geothermally heated along the flow path, which probably follows N-S trending fault zones.

Water samples collected from BBNP are meteoric (derived from rainfall) and gain chemicals through subsurface reaction with rocks and sediments. Dissolved chemicals are further concentrated by evaporation in some springs and streams, or by dissolution of soluble salts deposited when water evaporates. Water from hot springs reacts more intensely with rocks at higher temperatures and has higher contents of certain elements, especially arsenic and lithium. Rio Grande water is dominated by water from the Rio Conchos and carries more dissolved solids than most waters in BBNP. Cottonwood well water, which supplies the village of Castolon, contains high concentrations of sodium, calcium, chloride, sulfate, arsenic, and lithium from the dissolution of soluble salts in river alluvium and possibly from mixing with spent thermal water. 


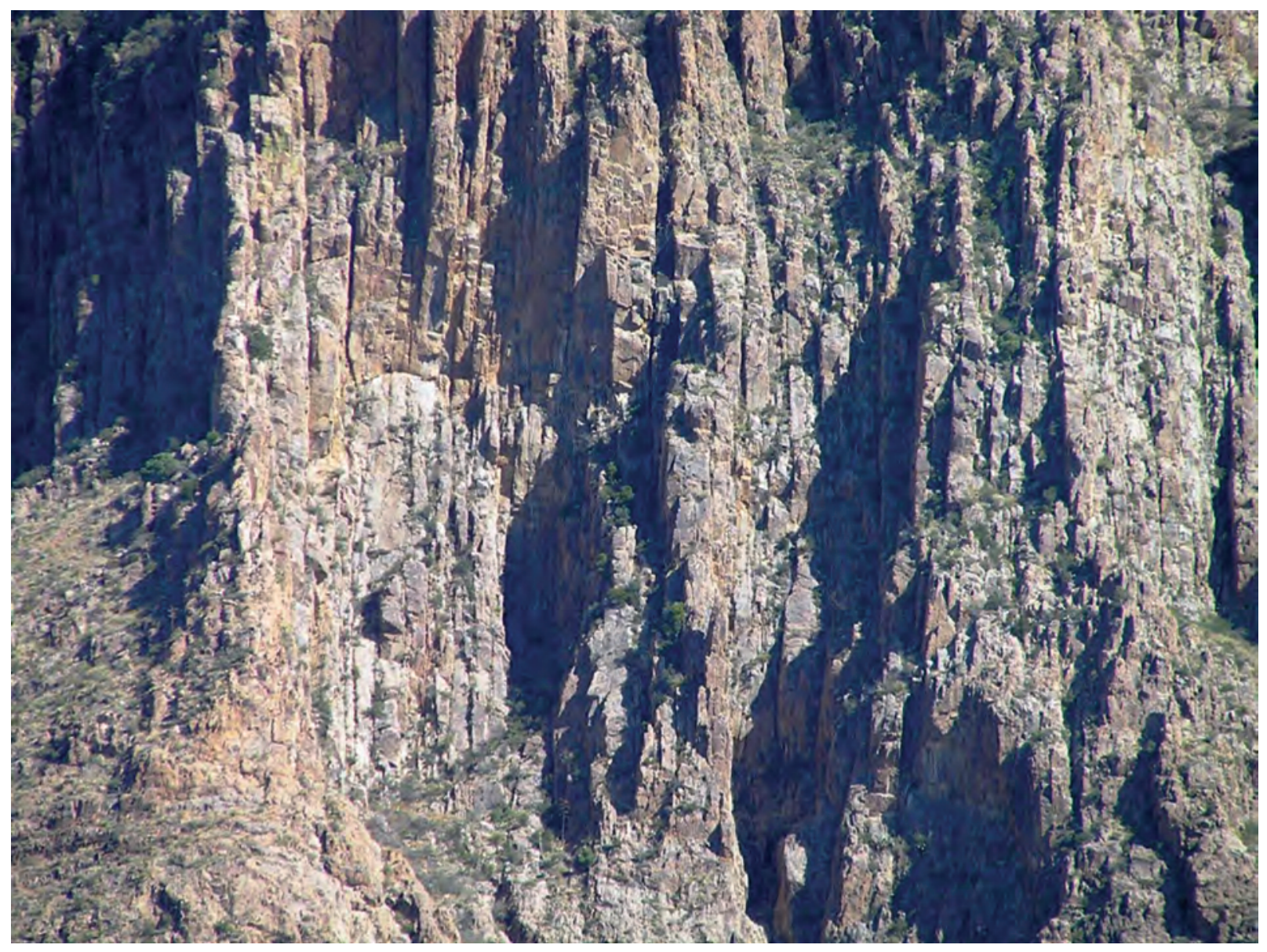

Figure 6-5. Photograph of vertical fractures (joints) in the Ward Mountain rhyolitic intrusive rocks east of Ward Spring. Such fractures, with spacing from centimeter to meter scales, are the likely conduits for subsurface fluid flow from The Basin through intrusive rocks in The Window area to Oak Spring below The Window pouroff. 


\section{Acknowledgments}

The authors thank Vidal Davila, Jeffrey Bennett, Betty Alex, Raymond Skiles, Tim Lafever, and Don Corrick of the National Park Service, Big Bend National Park, for assistance with field work and many helpful discussions. We thank Roland Thurston, Michael Anthony, Monique Adams, David Fey, and Casey Gulbransen of the U.S. Geological Survey for assistance with analyses and field work. The manuscript was reviewed by Rich Wanty and Phil Verplanck of the USGS. Finally we thank Louise Hamer of Wildhorse Station for good friendship and excellent accommodations during field work.

\section{References Cited}

Abbott, C.L., 1983, Bedrock aquifer geometry in the Panther Junction area of Big Bend National Park, Texas: College Station, Tex., Texas A\&M University, M.S. thesis, $113 \mathrm{p}$.

Aeschbach-Hertig, W., Peeters, F., Beyerle, U., and Kipfer, R., 1999, Interpretation of dissolved atmospheric noble gases in natural waters: Water Resources Research, v. 35, p. 2,779-2,792.

Baker, E.T., Jr., and Buszka, P.M., 1993, Hydrogeology, geochemistry, and quality of water of The Basin and Oak Spring Areas of the Chisos Mountains, Big Bend National Park, Texas: U.S. Geological Survey Water-Resources Investigations Report 93-4112, 76 p.

Craig, H., 1961, Isotopic variations in meteoric waters: Science, v. 133 , p. $1,702-1,703$.

Epstein, S., and Mayeda, T., 1953, Variations of $\mathrm{O}^{18}$ contents of waters from natural sources: Geochimica et Cosmochimica Acta, v. 4, p. 213-224.

Gibson, J.L., 1983, Ground-water hydrology of the Panther Junction area of Big Bend National Park, Texas: College Station, Tex., Texas A\&M University, M.S. thesis, 110 p.

Gutierrez, M., and Borrego, P., 1999, Water quality assessment of the Rio Conchos, Chihuahua, Mexico: Environment International, v. 25, p. 573-583.
Hageman, P.L., 2002, Mercury in water by flow injection-cold vapor-atomic fluorescence spectrometry, in Taggart, J.E., Jr., ed., Analytical methods for chemical analysis of geologic and other materials: U.S. Geological Survey Open-File Report 02-223, chap. N, 5 p.

Hellgren, E.C., 1993, Status, distribution, and summer food habits of black bears in Big Bend National Park: The Southwestern Naturalist, v. 38, p. 77-80.

Howari, F.M., 2002, Sources, types, storage, and release of salts in the soil-water system of the Rio Grande, Texas [abs.]: Geological Society of America Abstracts with Programs, v. 34, no. 6, p. 262.

Kendall, C., and Coplen, T.B., 1985, Multisample conversion of water to hydrogen by zinc for stable isotope determination: Analytical Chemistry, v. 57, p. 1,437-1,440.

Lamothe, P.J., Meier, A.L., and Wilson, S.A., 2002, The determination of forty four elements in aqueous samples by inductively coupled plasma-mass spectrometry, in Taggart, J.E., Jr., ed., Analytical methods for chemical analysis of geologic and other materials: U.S. Geological Survey OpenFile Report 02-223, chap. H, 11 p.

Maxwell, R.A., Lonsdale, J.T., Hazzard, R.T., and Wilson, J.A., 1967, Geology of Big Bend National Park, Brewster County, Texas: University of Texas at Austin, Bureau of Economic Geology Report 6711, 320 p.

Servicio Geológico Mexicano, 2003, Manuel Benavides H13-9, Chihuahua y Coahuila: Servicio Geológico Mexicano Carta Geológico-Minera, 1 sheet, scale 1:250,000.

Solomon, D.K., and Cook, P.G., 2000, ${ }^{3} \mathrm{H}$ and ${ }^{3} \mathrm{He}$, in Cook, P.G., and Herczeg, A.L., eds., Environmental tracers in subsurface hydrology: Boston, Kluwer Academic Publishers, p. 397-424.

Theodorakos, P.M., 2002, Fluoride, chloride, nitrate, and sulfate in aqueous solution utilizing auto-suppression chemically suppressed ion chromatography, in Taggart, J.E., Jr., ed., Analytical methods for chemical analysis of geologic and other materials: U.S. Geological Survey Open-File Report 02-223, chap. V, 7 p.

U.S. Environmental Protection Agency, 2007, Arsenic in drinking water-Basic information: U.S. Environmental Protection Agency, http://www.epa.gov/safewater/arsenic/ basicinformation.html. 


\title{
7. Stable Isotope and Trace Element Studies of Black Bear Hair, Big Bend Ecosystem, Texas and Mexico
}

\author{
By W.C. Pat Shanks III, Eric C. Hellgren, Craig Stricker, Pamela A. Gemery-Hill, and David P. Onorato
}

\section{Abstract}

Hair from black bears (Ursus americanus), collected from four areas in the Big Bend ecosystem, has been analyzed for stable isotopes of carbon, nitrogen, and sulfur to determine major food sources and for trace metals to infer possible effects of environmental contaminants. Results indicate that black bears are largely vegetarian, feeding on desert plants, nuts, and berries. Mercury concentrations in bear hair are below safe level standards $(<2 \mu \mathrm{g} / \mathrm{g})$, and other trace metal concentrations are generally below levels that have been associated with adverse affects in other mammals. These results indicate low potential for negative health affects on bears due to trace element contaminants in the Big Bend ecosystem.

\section{Introduction}

Naturalist Vernon Bailey described bears as common in the upper canyons of the Chisos Mountains in 1901 (Bailey, 1905). When Big Bend National Park (BBNP) was established in 1944, there were virtually no resident bears due to extirpation by Federal predator control and unregulated hunting (Onorato and Hellgren, 2001). Black bears reappeared in BBNP in the late 1980s. Sightings (fig. 7-1) increased dramatically after 1988 and included evidence of residency and breeding pairs (Hellgren and others, 2005). These observations allowed estimation of up to 6 resident adult females and 30 total individuals in the Park in 2000, with a decline to 2-3 females in 2001-2002 after an exodus to Mexico in the fall of 2000 (Hellgren and others, 2005).

Natural recolonization by bears is extremely rare and is of interest for predicting similar events in other parts of the Trans-Pecos region. Migrations into the BBNP area are believed to have come from the larger Sierra del Carmen and Serranias del Burro mountain ranges in Mexico (fig. 7-2). Bears in the region concentrate in montane islands like the Chisos Mountains, showing a preference for moderate to high elevations with pinyon-oak-juniper habitat, where they feed on acorns, juniper berries, pinyon nuts, and berries of
Texas madrone and sumac. They also may feed on sotol, yucca, lechuguilla, and on prickly pear and persimmon fruits. Hellgren (1993) used scat analysis to conclude that black bear diet in the Chisos Mountains consists of 77-86 percent plant material with an emphasis on succulents, fruits, and nuts, and only 11-14 percent animal material, roughly half of which was black bear hair (from grooming) and half insects.

Past mining activities in the Big Bend area, including mercury, fluorite, and silver-lead-zinc mines, justify assessment of important possible impacts of mining-related contaminants on the ecosystem. For example, Mora and others (2002) noted that Peregrine falcons (Falco peregrinus anatum) have low reproductive rates in BBNP, which might be caused by metal contamination or organic toxins such as DDE (a metabolite of DDT). They examined metals and organic contaminants in Peregrine falcon prey species including Black phoebe (Sayornis nigricans), Say's phoebe (Sayornis saya), Cliff swallow (Petrochlidon pyrrhonota), Northern rough-winged swallow (Stelgidopteryx serripennis), and Mexican free-tailed bat (Tadarida brasiliensis); they found mercury up to $2.5 \mu \mathrm{g} / \mathrm{g}$ $\mathrm{dw}$ (micrograms per gram dry weight) and selenium up to 15 $\mu \mathrm{g} / \mathrm{g}$ dw. Many of the measured mercury concentrations are above the threshold of $0.4 \mu \mathrm{g} / \mathrm{g} \mathrm{dw}$ accepted for protection of bird health (Eisler, 1987). Mora and others (2002) noted cases of selenium concentrations of $14.5-16.5 \mu \mathrm{g} / \mathrm{g} \mathrm{dw}$ in the diet that produced embryo deformities and oxidative stress in nestlings, so some of the prey species concentrations are in the range where adverse effects might be expected. All of the prey species analyzed in BBNP are insectivorous and Mora and others (2002) suggested that mercury in the insects originated in former mine sites, whereas selenium may be related to agricultural fertilization and irrigation practices.

The purpose of this study was to use stable isotope (carbon, C; nitrogen, N; and sulfur, S) and trace element data derived from bear guard hairs to assess dietary habits and evaluate possible trace metal accumulation resulting from mine waste or agricultural practices within the ecosystem. Hair samples analyzed in the present study were collected from bears in the Chisos Mountains, Black Gap Wildlife Management Area, and from the Sierra del Carmen and Serranias del Burro ranges in Mexico (fig. 7-2) (Onorato and others, 2004). 


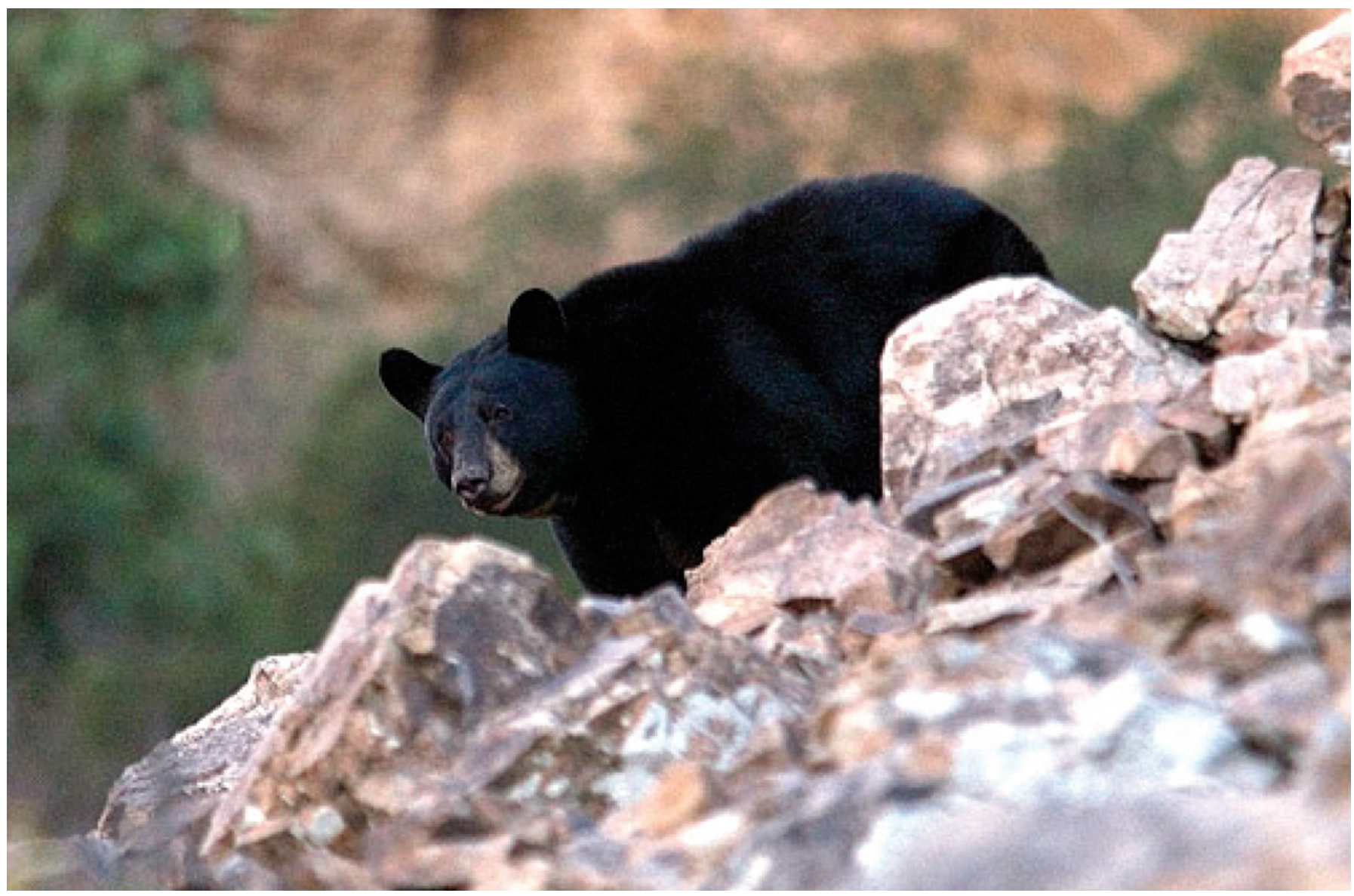

Figure 7-1. Black bear in Big Bend National Park.

\section{Stable Isotopes and Bear Diet}

Many elements have more than one stable (non-radioactive) isotope. Isotopes of an element have a different number of neutrons in the nucleus, but because they are the same element, have almost identical chemical and physical properties. However, some natural processes produce small changes, called fractionation, in the ratio of stable isotopes in a substance. These small changes can be measured with a mass spectrometer and provide information on processes that have affected the substance. In the case of stable isotopes in animals, the classic studies of DeNiro and Epstein $(1978,1981)$ have shown that "you are what you eat." Modern techniques allow automated, high-precision analysis of stable isotopes in plant and animal materials (Fry and others, 1992; Kester and others, 2001).

Hilderbrand and others (1996) studied stable isotopes $\left(\delta^{15} \mathrm{~N}\right.$ and $\left.\delta^{13} \mathrm{C}\right)$ in diets of captive bears and demonstrated a strong correlation between isotope values in plasma and foods. They also showed that hair, bone collagen, and red blood cells have the same isotopic values as plasma and foods when animals are on a consistent diet. Thus, stable isotopic analysis of BBNP black bear hair provides a tool for assessing diet.
Results (table 7-1) of $\delta^{13} \mathrm{C}$ studies of bear hair from the four areas sampled indicate that bear diet in the Big Bend area comprises mainly plants that thrive in desert environments. Plants in arid environments use one of two different metabolic pathways in photosynthesis (either C4 or CAM, crassulacean acid metabolism, an elaborate carbon fixation pathway in some photosynthetic plants usually found in plants living in arid conditions). These pathways contrast with most woody plants, which utilize the $\mathrm{C} 3$ metabolic pathway. Plants that use $\mathrm{C} 4$ metabolism include sugar cane, maize, sorghum, finger millet, amaranth, and switchgrass. Plants that use CAM metabolism include succulents, cacti, and flowering plants.

Park and Epstein (1961) were the first to show that different types of plants fractionate carbon isotopes differently during photosynthesis of atmospheric carbon dioxide $\left(\mathrm{CO}_{2}\right)$. As a result, $\mathrm{C} 4$ plants have higher $\delta^{13} \mathrm{C}$ ranges $(-11$ to -15$)$ than the much more abundant $\mathrm{C} 3$ plants (-20 to -35$)$, and CAM plants have intermediate values (-15 to -19) (Dawson and others, 2002). Therefore, differences in $\delta^{13} \mathrm{C}$ values of plants relate to the photosynthetic pathways for fixation of 


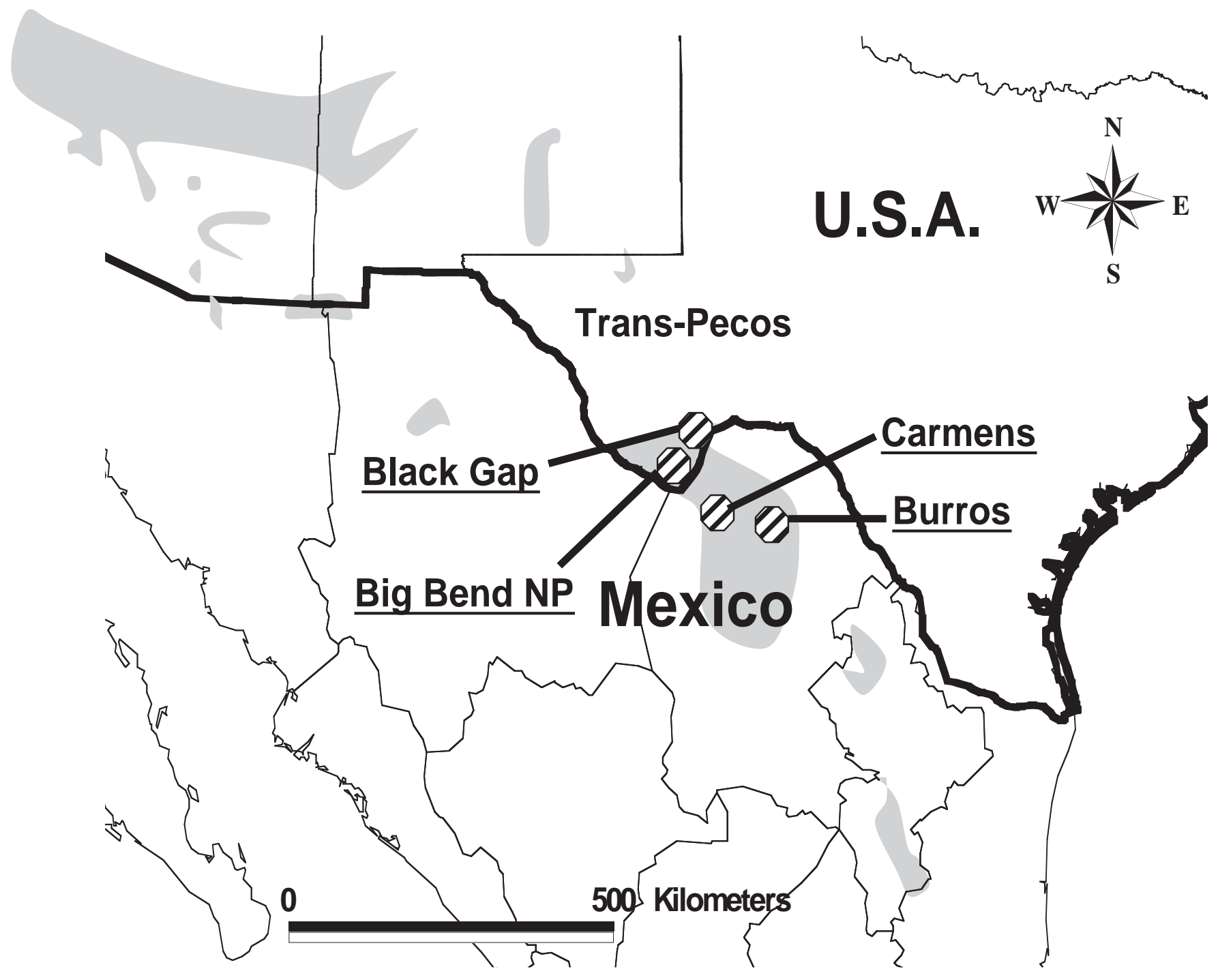

Figure 7-2. Map showing general location of the Big Bend ecosystem where black bear hair samples were collected for this study. Shaded areas show black bear range. From Onorato and others (2004). 


\section{Trace Elements in Bear Hair}

$\mathrm{CO}_{2}$ (Farquhar and others, 1982). The $\delta^{13} \mathrm{C}$ values of Big Bend bear hair (-16.9 to -19.8 ; table 7-1) and the feeding habits deduced from scat analysis suggest a significant fraction of $\mathrm{CAM}$ and possibly $\mathrm{C} 4$ plants in the diet.

Fellicetti and others (2003) studied stable isotopes in grizzly bear (Ursus arctos horribilis) hair and possible bear foods in Yellowstone National Park and showed that nitrogen and sulfur isotopes also are quite useful for estimating assimilated diets. Plots of nitrogen isotopes versus carbon and sulfur isotope values for Big Bend black bear hair (fig. 7-3) show fairly confined ranges with some possible differences between different geographic locations. The less-depleted $\delta^{13} \mathrm{C}$ values in the Chisos and the Black Gap samples may not be significant statistically from the two Mexican ranges, but their lower elevation and more arid environment is consistent with more $\mathrm{C} 4$ and CAM plants in the diet.

Ranges for $\delta^{13} \mathrm{C}$ and $\delta^{34} \mathrm{~S}$ in Yellowstone National Park (YNP) grizzly bear hair (Felicetti and others, 2003; Chaffee and others, 2007) are also outlined on figure 7-3 and show quite a different range than Big Bend black bear hair. Felicetti and others (2003) and Chaffee and others (2007) also collected and analyzed potential food sources consumed by YNP grizzly bears; the ranges of isotope values are indicated in figure 7-3. The ranges of values for individual food sources demonstrate that pine nuts, fish, and ungulates are critically important food resources for Yellowstone grizzly bears, while moths and vegetation are also part of their diet, and the diet varies temporally during the year and from year to year depending on the size of mast and spawning runs. Similar detailed analysis of Big Bend bear diet and potential foods are in progress. Some of the differences in isotope values (fig. 7-3) among bears from Chisos, Black Gap, and Burro Mountains/Sierra del Carmen may be related to differences in aridity, foods, or geological environment.
Trace element studies of BBNP bear hair (table 7-2) indicate detectable concentrations as follows, with average and range of concentrations in $\mu \mathrm{g} / \mathrm{g}$ for all samples in parentheses: barium (Ba: 13; 2-43), cadmium (Cd: 1.2; 0.04-9.9), copper (Cu: 15; 7-49), iron (Fe: 319; <50-1,120), mercury (Hg: 0.1; $<0.02-0.2$ ), manganese (Mn: 17; 1-51), molybdenum (Mo: $0.2 ;<0.05-0.2$ ), nickel (Ni: $5.5 ; 1.4-14)$, lead (Pb: 3.1; 0.730.0), selenium (Se: 1.2; <1-2), and zinc (Zn: 129; 94-151). Except for mercury, few comparative data are available in the literature. Concentrations of $\mathrm{Hg}$ are low $(0.1 \mu \mathrm{g} / \mathrm{g})$ compared to grizzly bear from Yellowstone National Park (17-2,600 $\mu \mathrm{g} / \mathrm{g}$ ) that feed on spawning cutthroat trout. Concentrations of $\mathrm{Ba}, \mathrm{Cd}, \mathrm{Cu}, \mathrm{Mn}, \mathrm{Ni}$, and $\mathrm{Pb}$ are generally higher in Big Bend bear hair than in YNP hair, whereas $\mathrm{Zn}$ is lower.

Standards for metal concentrations in mammal hair have not been set for many elements, but there are some studies that can be compared. Mora and others (2000) analyzed the hair of ocelots from the lower Rio Grande valley. They found the following average concentrations- $\mathrm{Hg}(0.7 \mu \mathrm{g} / \mathrm{g}), \mathrm{Se}(5.9$ $\mu \mathrm{g} / \mathrm{g})$, and $\mathrm{Pb}(0.7 \mu \mathrm{g} / \mathrm{g})$ - and observed no adverse effects on the animals. These ocelot $\mathrm{Hg}$ and Se concentrations are well above those for BBNP bears, but $\mathrm{Pb}$ is about 4-7 times higher in the BBNP bears. Burger and others (1994) studied hair from healthy opossum in a national park in Puerto Rico, mainly to establish concentrations so these abundant omnivorous marsupials can be used as bio-monitors for future contaminants as agricultural development proceeds. They found the following concentrations (average and standard error, $\mu \mathrm{g} / \mathrm{g} \mathrm{dw}$ ): $\mathrm{Cd}(36$ $\pm 4), \mathrm{Hg}(228 \pm 30), \mathrm{Mn}(34,119 \pm 7,867)$, and $\mathrm{Pb}(319 \pm 46)$. These concentrations are all significantly higher than those measured in the Big Bend bear hair. Thus, the concentrations measured for bear hair from the Big Bend ecosystem (table 7-2) are generally below concentrations found in other mammal hair from apparently healthy ecosystems.

Table 7-1. Stable isotope data for bear hair in the Big Bend National Park area.

[Stable isotope values are per mil deviations from the carbon isotope standard VPDB (Vienna Peedee Belemnite), nitrogen isotope standard AIR (atmospheric nitrogen composition), and the sulfur isotope standard VCDT (Vienna Canyon Diablo Trolite); \pm values are 1 standard deviation]

\begin{tabular}{|c|c|c|c|c|}
\hline & $\delta^{13} \mathbf{C}_{\mathrm{VPDB}}$ & $\delta^{15} \mathbf{N}_{\text {AIR }}$ & $\delta^{34} \mathbf{S}_{\mathrm{vCDT}}$ & \\
\hline Black Gap Wildlife Area, Tex. & $-17.1 \pm 2.2$ & $5.1 \pm 0.3$ & $7.7 \pm 0.1$ & $(n=2)$ \\
\hline Serranias del Burro mountains, Mexico & $-19.8 \pm 0.7$ & $4.1 \pm 0.5$ & $7.3 \pm 0.5$ & $(\mathrm{n}=9)$ \\
\hline
\end{tabular}



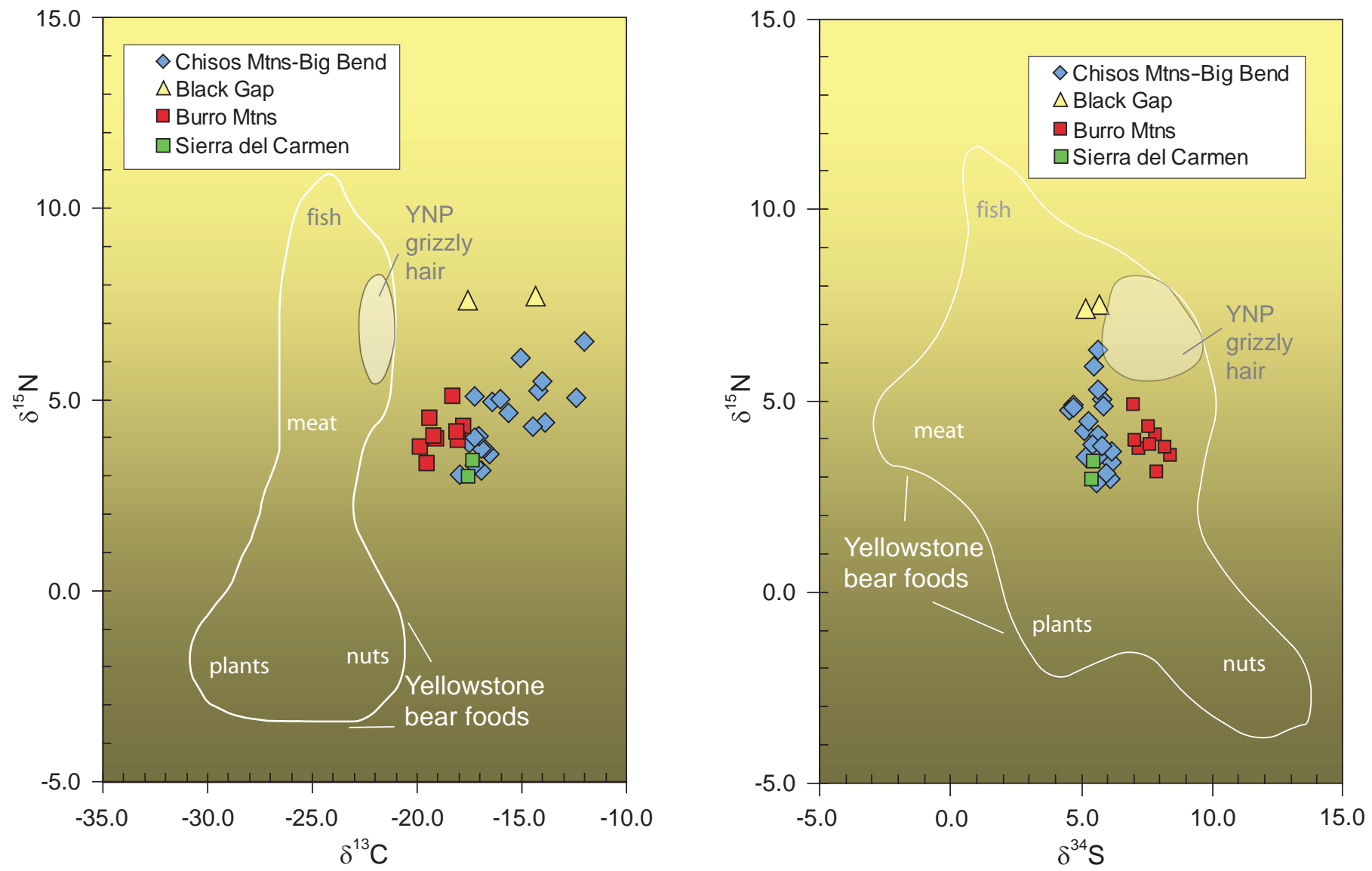

Figure 7-3. Plots of nitrogen isotopes versus carbon and sulfur isotope values for Big Bend black bear hair. Ranges for Yellowstone National Park (YNP) grizzly bear hair and potential YNP grizzly bear foods are shown for comparison (from Felicetti and others, 2003; Chaffee and others, 2007). 
Table 7-2. Average composition and standard deviation of selected elements in Big Bend National Park bear hair (all concentrations in $\mu \mathrm{g} / \mathrm{g}$, dry weight).

[All samples had concentrations less than the following detection limits in $\mu \mathrm{g} / \mathrm{g}$ : Ag $<2$, As $<1, \mathrm{Tl}<0.08$, Gd, Ho, Ta $<0.02$, Tm $<0.006$. All elemental analyses by Inductively Coupled Plasma-Mass Spectrometry following acid decomposition, except Hg analyzed by Cold Vapor Atomic Absorption Spectrometry. Ba, Barium; Cd, Cadmium; Cu, Copper; Fe, Iron; Hg, Mercury; Mn, Manganese; Mo, Molybdenum; Ni, Nickel; Pb, Lead; Se, Selenium; and Zn, Zinc]

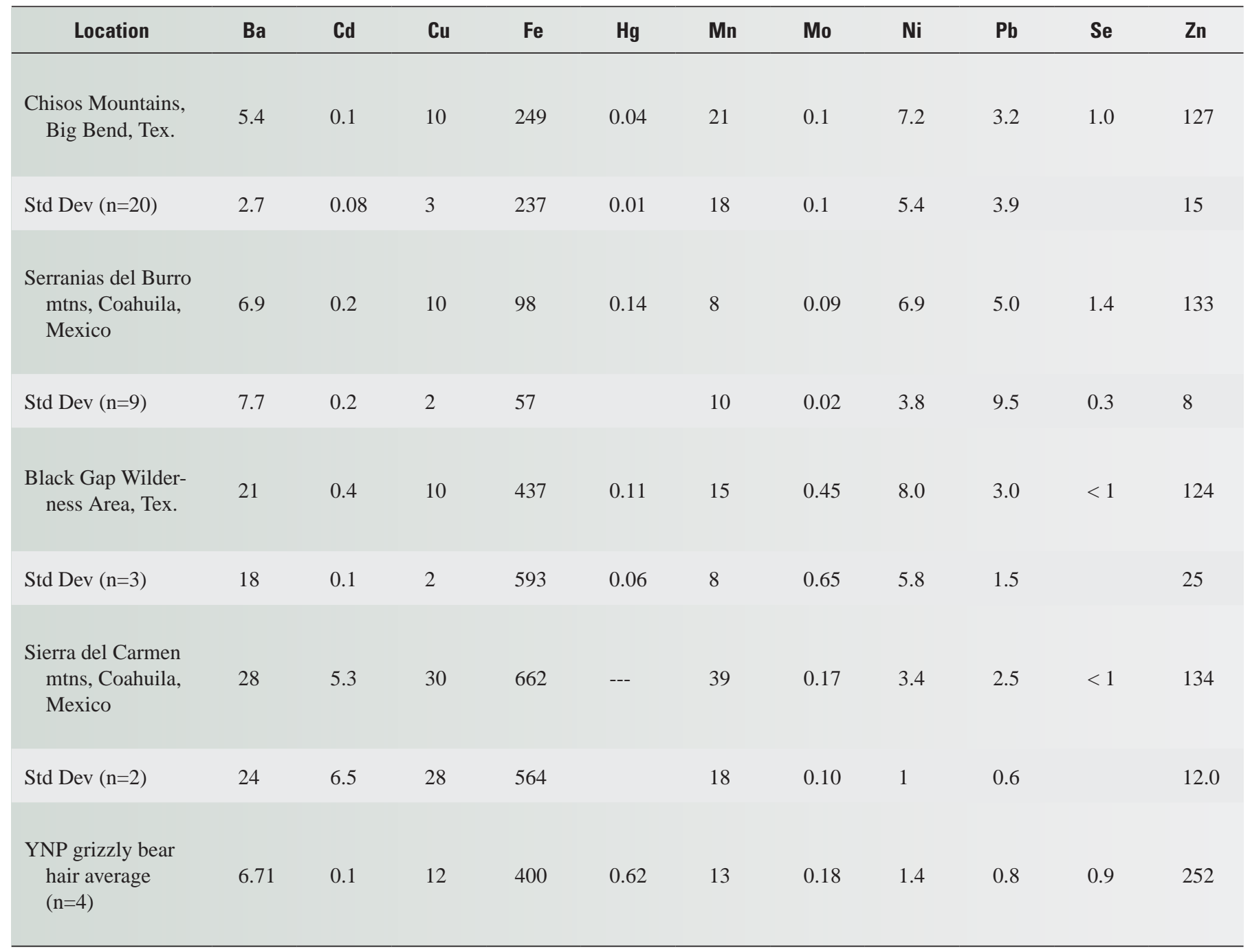


Eisler (1987) proposed that mercury concentrations in mammal hair at levels less than $2 \mu \mathrm{g} / \mathrm{g}$ constitute a safe level standard for animal health. Mercury analyses for BBNP bear hair are all at least a factor of ten below this standard. Additional information on mercury comes from feeding trials on captive bears (Felliceti and others, 2004) that demonstrated a direct correlation between mercury in a diet of fish from Yellowstone Lake and mercury in blood, plasma, and hair of the bears. They also sampled 42 Yellowstone grizzly bears with hair traps along cutthroat trout spawning streams and found mercury concentrations in hair that averaged about $360 \mu \mathrm{g} / \mathrm{g}$ and ranged from 17 to $2,600 \mu \mathrm{g} / \mathrm{g}$.

Fellicetti and others (2004) did not conduct controlled studies to examine the effects of mercury intake on reproduction by grizzly bears. However, they note that captive adult grizzly bears fed large amounts of salmon containing an average of $240 \mu \mathrm{g} / \mathrm{g} \mathrm{Hg}$ over multiple years had hair mercury concentrations averaging 4,778 $\mu \mathrm{g} / \mathrm{g}$ (9-35 times higher than YNP bears) and still showed healthy reproduction. Thus, it is unlikely that Big Bend black bears, with average $\mathrm{Hg}$ concentrations in hair of $0.1 \mu \mathrm{g} / \mathrm{g}$, have adverse health effects related to mercury in the diet.

One big distinction between BBNP and YNP bear populations is that the latter have a higher proportion of meat and fish in the diet. Plants bio-accumulate far less mercury than animals, and the BBNP bears are feeding at a relatively low trophic level on a food web that appears to be rather simple (plants and bugs). Thus, despite a habitat with potentially high metal contamination in some areas, mercury does not appear to have propagated into higher consumers, such as bears.

\section{Conclusions}

Stable isotope analysis of carbon, nitrogen, and sulfur in black bear hair is a useful tool for understanding the diet of bears. Future studies of bear foods will allow more detailed conclusions, but data presented here indicate that bear from the Big Bend area are largely vegetarians that feed on $\mathrm{C} 4$ and CAM plants, which flourish in the desert environment. Trace metal studies of bear hair indicate low concentrations of $\mathrm{Hg}$, suggesting that black bear are not being adversely affected by mercury in the environment around BBNP.

\section{References Cited}

Bailey, V., 1905, Biological survey of Texas: U.S. Department of Agriculture, Bureau of the Biological Survey North American Fauna Number 25, 216 p.

Burger, J., Marquez, M., and Gochfeld, M., 1994, Heavy metals in the hair of opossum from Palo Verde, Costa Rica: Archives of Environmental Contamination and Toxicology, v. 27 , p. $472-476$.

Chaffee, M.A., Shanks, W.C., III, Rye, R.O., Schwartz, C.C., Carlson, R.R., Crock, J.G., Adams, M., Gemery, P.A., Gunther, K.A., Kester, C.L., King, H.D., and Podruzny, S.R., 2007, Applications of trace-element and stable-isotope geochemistry to wildlife issues, Yellowstone National Park and vicinity, in Morgan, L.A., ed., Integrated geoscience studies in the greater Yellowstone area-Volcanic, hydrothermal and tectonic processes in the Yellowstone geoecosystem: U.S. Geological Survey Professional Paper 1717, p. 299-334.

Dawson, T.E., Mambelli, S., Plamboeck, A.H., Templer, P.H., and Tu, K.P., 2002, Stable isotopes in plant ecology: Annual Review of Ecological Systems, v. 33, p. 507-559.

DeNiro, M.J., and Epstein, S., 1978, Influence of diet on the distribution of carbon isotopes in animals: Geochimica et Cosmochimica Acta, v. 42, p. 495-506.

DeNiro, M.J., and Epstein, S., 1981, Influence of diet on the distribution of nitrogen isotopes in animals: Geochimica et Cosmochimica Acta, v. 45, p. 341-351.

Eisler, R. 1987, Mercury hazards to fish, wildlife, and invertebrates-A synoptic review: U.S. Fish and Wildlife Service Biological Report 85(1.10), 90 p.

Farquhar, G.D., O'Leary, M.H., and Berry, J.A., 1982, On the relationship between carbon isotope discrimination and the intercellular carbon dioxide concentration in leaves: Australian Journal of Plant Physiology, v. 9, p. 121-137.

Felicetti, L.A., Schwartz, C.C., Rye, R.O., Gunther, K.A., Crock, J.G., Haroldson, M.A., Waits, L., and Robbins, C.T., 2004, Use of naturally occurring mercury to determine the importance of cutthroat trout to Yellowstone grizzly bears: Canadian Journal of Zoology, v. 82, p. 493-501.

Felicetti, L.A., Schwartz, C.C., Rye, R.O., Haroldson, M.A., Gunther, K.A., Phillips, D.L., and Robbins, C.T., 2003, Use of sulfur and nitrogen stable isotopes to determine the importance of whitebark pine nuts to Yellowstone grizzly bears: Canadian Journal of Zoology, v. 81, p. 763-770.

Fry, B., Brand, W., Mersch, F.J., Tholke, K., and Garritt, R., 1992, Automated analysis system for coupled $\delta^{13} \mathrm{C}$ and $\delta^{15} \mathrm{~N}$ measurements: Analytical Chemistry, v. 64, p. 288-291. 
Hellgren, E.C., 1993, Status, distribution, and summer food habits of black bears in Big Bend National Park: The Southwestern Naturalist, v. 38, p. 77-80.

Hellgren, E.C., Onorato, D.P, and Skiles, J.R., Jr., 2005, Dynamics of a black bear population within a desert metapopulation: Biological Conservation, v. 122, p. 131-140.

Hilderbrand, G.V., Farley, S.D., Robbins, C.T., Hanley, T.A., Titus, K., and Servheen, C., 1996, Use of stable isotopes to determine diets of living and extinct bears: Canadian Journal of Zoology, v. 74, p. 2,080-2,088.

Kester, C.L., Rye, R.O., Johnson, C.A., Schwartz, C.C., and Holmes, C.W., 2001, On-line sulfur isotope analysis of organic material by direct combustion-Preliminary results and potential applications: Isotopes Environmental Health Studies, v. 37, p. 53-65.

Mora, M.A., Laack, L.L., Lee, M.C., Sericano, J., Presley, R., Gardinali, P.R., Gamble, L.R., Robertson, S., and Frank, D., 2000, Environmental contaminants in blood, hair, and tissues of ocelots from the lower Rio Grande Valley, Texas, 1986-1997: Environmental Monitoring and Assessment, v. 64, p. 477-492.

Mora, M., Skiles, R., McKinney, B., Paredes, M., Buckler, D., Papoulias, D., and Klein, D., 2002, Environmental contaminants in prey and tissues of the peregrine falcon in the Big Bend Region, Texas, USA: Environmental Pollution, v. 116, p. 169-176.

Onorato, D.P., and Hellgren, E.C., 2001, Black bear at the border-Natural recolonization of the Trans-Pecos, in Maehr, D.S., Noss, R., and Larkin, J., eds., Large mammal restoration-Ecological and sociological challenges in the $21^{\text {st }}$ century: Washington, D.C., Island Press, p. 245-259.

Onorato, D.P., Hellgren, E.C., Van Den Bussche, R.A., and Skiles, J.R., Jr., 2004, Paternity and relatedness of American black bears recolonizing a desert montane island: Canadian Journal of Zoology, v. 82, p. 1,201-1,210.

Park, R. and Epstein, S., 1961, Metabolic fractionation of $\mathrm{C}^{12}$ and $\mathrm{C}^{13}$ in plants: Plant Physiology, v. 36, p. 133-138. 


\title{
8. Aeromagnetic and Radioelement Analyses Identify Igneous Rocks in the Big Bend National Park Region
}

\author{
By Carol A. Finn and Eric D. Anderson
}

\section{Abstract}

Airborne magnetic and radioelement surveys were flown over the Big Bend National Park region in order to aid in surficial and subsurface geologic mapping. The data were collected along northeast-southwest lines spaced $400 \mathrm{~m}$ apart at a nominal flight height of approximately $400 \mathrm{~m}$ above the ground (Drenth and Finn, 2007). Aeromagnetic data facilitate geologic mapping of igneous rocks and faults in the inaccessible terrane of the Big Bend National Park region by mapping the distribution of magnetic minerals at and beneath the surface. Variations in magnetization that reflect differences in concentrations of magnetic minerals produce observed magnetic anomalies. The radioelement data are used to estimate the concentrations of potassium, uranium, and thorium in the near-surface soils and rocks (most of the gamma-rays detected originate in the top $30 \mathrm{~cm}$ of material). These estimated concentrations can in turn provide clues regarding the lithologic characteristics of the materials. In this paper, we provide a broad overview of how to use aeromagnetic data to map both exposed and buried igneous rocks and a brief description of radioelement mapping of the surficial igneous geology.

\section{Identifying Igneous Rocks with Aeromagnetic Data}

The dramatic topography of Big Bend National Park is largely formed or influenced by igneous processes. The aeromagnetic data provide a critical tool for imaging significant intrusions and thick sections of volcanic rocks. In order to facilitate geologic interpretation, reduction to pole transformation (a standard geophysical technique to center anomalies over their sources) was applied to the total field magnetic data (fig. 8-1A) (Baranov and Naudy, 1964; Blakely, 1995). Magnetic highs (red colors) centered over their exposed and buried Tertiary igneous sources dominate the reduced to the pole magnetic map of the region. The buried rocks are identified as continuations of anomalies related to similar magnetic signatures from exposed rocks. Most of the topographic features in the park are influenced by intrusions at varying scales. Many of the broad, high amplitude anomalies correlate with topography produced by laccoliths and other intrusive bodies such as the Rosillos Mountains granitic laccolith (fig. 8-1B) (Anderson, 2007) and the Chisos Mountains, which are underlain by a large buried intrusion that presumably caused the uplift of the mountains (fig. 8-1C) (Drenth and Finn, 2007). Other small buried intrusions often cause local doming of beds (fig. 8-2) that, in places, is superimposed on uplift related to the Laramide orogeny (for example, east of Javalina Creek, fig. 8-1A). Not all intrusions produce magnetic anomalies (compare outcrop with anomalies, fig. 8-1A), either because they are too thin or their magnetization does not significantly differ from surrounding rocks, or both. Many of the mapped geologic units in the Big Bend region, particularly the sedimentary and volcaniclastic rocks, lack spatial correlation with magnetic anomalies, leading to the interpretation that these units are not anomaly sources.

Other sources of magnetic anomalies include normally and reversely magnetized Tertiary volcanic rocks, which produce magnetic highs and lows, respectively. Reversely magnetized volcanic rocks fill calderas in the northeastern and southwestern edges of the Chisos Mountains and in the Christmas Mountains (fig. 8-1A). Other small circular, highamplitude magnetic lows may relate to old volcanic centers. Mapped lava flows in the northeastern portion of the map produce generally northwest trending high amplitude magnetic highs and lows. Northwest trending magnetic highs and lows over the rest of this region may indicate similar buried or unmapped igneous sources, such as those over mafic lavas exposed southwest of the Chisos Mountains. The high amplitude, northeast trending magnetic highs in the western portion of the region (fig. 8-1A) delineate buried pre-Tertiary basement rocks-perhaps Precambrian in age (Drenth and Finn, 2007).

The magnetic data can be used to estimate the depths to buried sources and, where constrained by geologic mapping and rock property measurements, to determine the source geometry. Depth estimates show that most sources in the region lie in the upper 1,600 $\mathrm{m}$ of the surface. Three dimensional models (fig. 8-1B), show that an 800-m-thick, 12-km-diameter granitic laccolith underlies the Rosillos Mountains (Anderson, 2007). Other laccoliths in the region, 

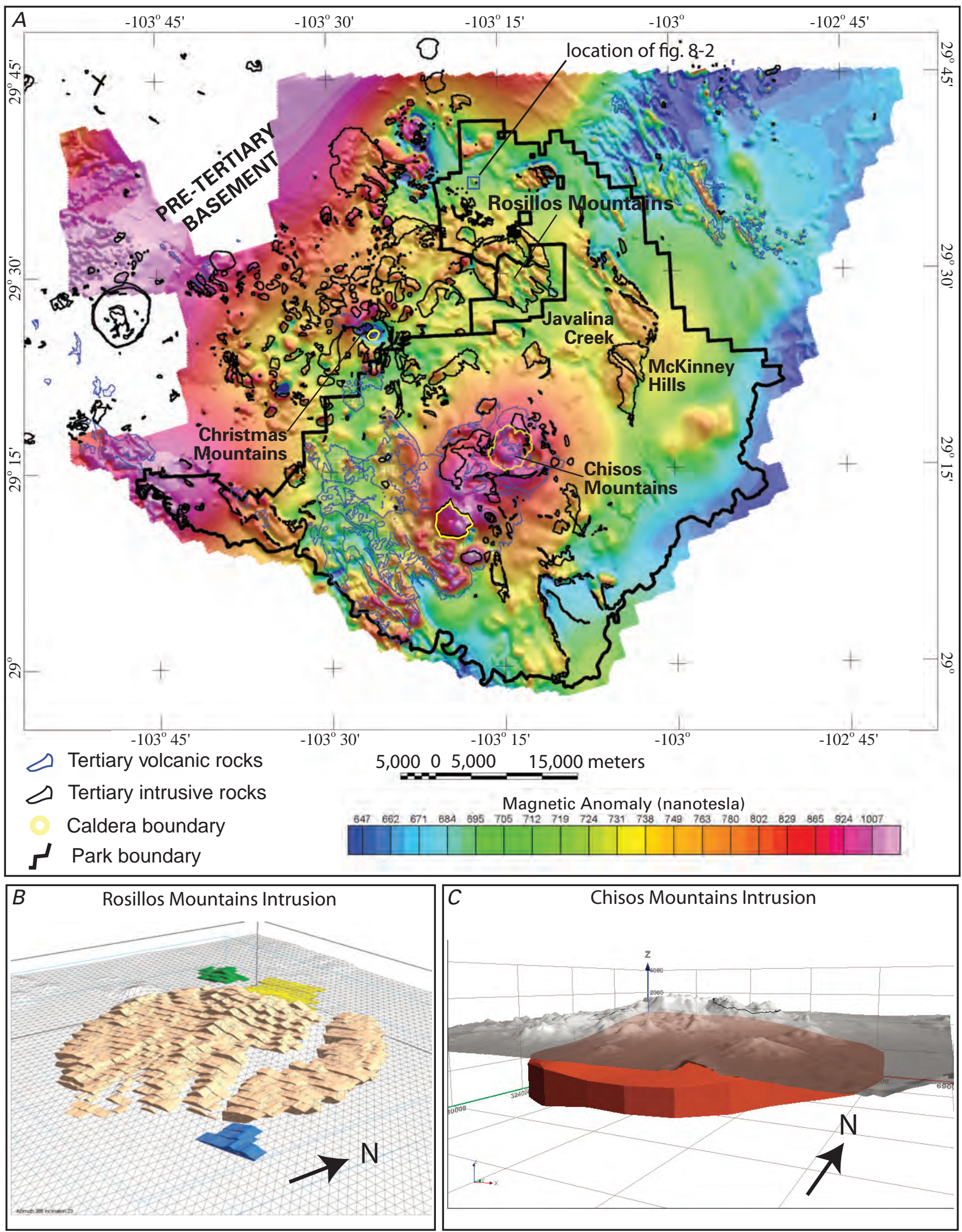
Figure 8-1 (facing page). Magnetic anomaly and magnetic sources from the Big Bend National Park region. $A$, Color shaded relief image of reduced to pole magnetic anomaly map with outlines of selected geologic units (Barnes, 1979). Blue box north of the Rosillos Mountains shows the location of figure 8-2. $B$, Magnetic model of the Rosillos laccolith (Anderson, 2007). The topography is shown as a blue triangulated mesh; beige body represents the Rosillos laccolith; green and blue bodies represent Tertiary reversely magnetized intrusions; yellow body is a thin, normally magnetized intrusive body. View is to the northwest. $C$, Magnetic model of the Chisos Mountains intrusion (from Drenth and Finn, 2007). Gray shaded surface is the digital elevation model; black lines outline the Pine Canyon (NE) and Sierra Quemada (SW) calderas; and the orange body represents the intrusion with a susceptibility of $0.03 \mathrm{SI}$. View is from the southwest. such as the McKinney Hills and Javalina Creek, have similar amplitude and wavelength anomalies (fig. 8-1A), suggesting comparable thickness and geometry. The largest intrusion in the region underlies the Chisos Mountains (fig. 8-1C) and is approximately $1-4 \mathrm{~km}$ thick and $28-34 \mathrm{~km}$ in diameter (Drenth and Finn, 2007).

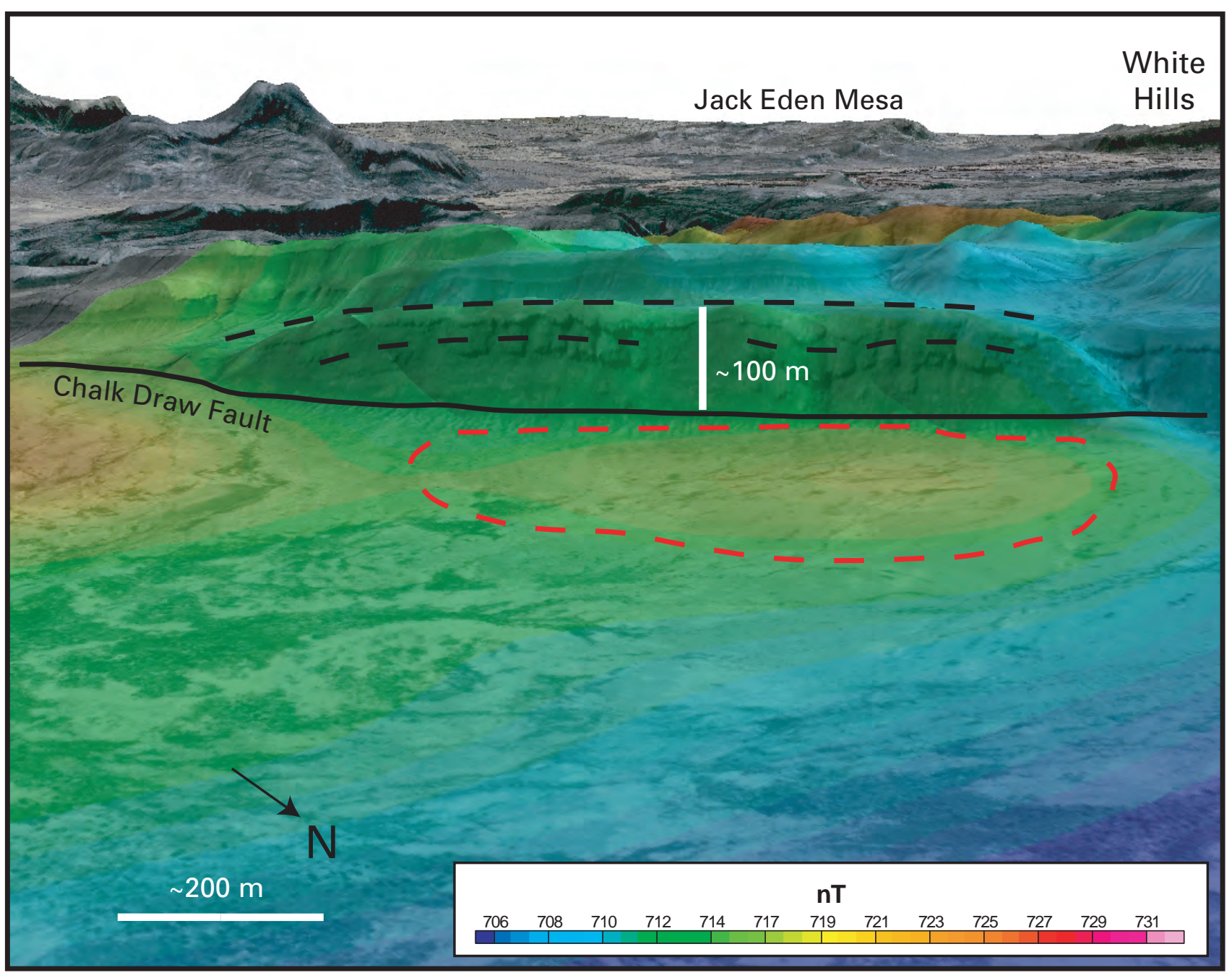

Figure 8-2. Magnetic data (colors) superimposed on an aerial photo draped on a DEM along the south central portion of the Chalk Draw Fault. Red dotted line indicates approx. $10 \mathrm{nT}$ high related to a buried intrusion. View from the northeast. Vertical exaggeration is 2 . 


\section{Identifying Faults with Aeromagnetic Data \\ Identifying Surficial Geologic Units with Radioelement Data}

Faults, fractures, and lithologic contacts can be delineated by the magnitude of the horizontal gradients of the reduced to pole aeromagnetic anomalies (Cordell and Grauch, 1985; Phillips, 2000). Local maxima that form linear and curved ridges mark magnetic property contrasts in the subsurface. Closed circular peaks suggest magnetic sources such as laccoliths, plugs, caldera boundaries, and cinder cones. Long, narrow, linear peaks typically indicate faults or dikes. In some locations circular peaks interrupt linear trends (for example, in the south central region of the park, fig. 8-3), suggesting that igneous bodies intrude fault planes, which indicates whether igneous activity is either syn- or post-tectonic.

The mapped faults almost exclusively trend NNW with a few NE trending faults (fig. 8-3). The NNW trend dominates the local extrema from the maximum horizontal gradient data, but the NE trend is also prominent. Many mapped faults correspond to maxima of the horizontal gradient, but many do not. Some mapped faults are parallel to nearby gradient maxima, which could indicate that the faults offset magnetite-poor rocks at the surface and more magnetic ones at depth and dip in the direction of the gradient. The faults that do not correspond to magnetic gradient maxima typically offset magnetitepoor rocks at the surface, but not deeper magnetic sources (such as in the northwest portion of the region, fig. 8-3). This suggests that the faults have limited vertical extent. Although the NNW trend parallels Cretaceous structures, most of the faults cut Tertiary intrusions, including the Rosillos laccolith (fig. 8-1B), indicating that they formed in the Late Tertiary during northwest-directed Basin and Range Extension. The magnetic model from the Rosillos laccolith indicates that the faults do not have significant vertical offset (300-600 m) and have no demonstrable horizontal offset (fig. 8-1B).
Radioelement data can be used to help map surficial rock types. Here, we use the data to further the understanding of the distribution and composition of surficial igneous rocks. In order to maximize the utility of the radioelement data, we added gridded potassium (red), thorium (green), and uranium (blue) data together to produce a ternary radioelement map (fig. 8-4). White regions contain high concentrations of all three elements, whereas dark areas contain low concentrations.

Tertiary intrusions in the region are enriched in potassium, uranium, and thorium, as are most of the volcanic rocks (fig. 8-4). Intrusions slightly enriched in thorium (yellow color), such as the Rosillos laccolith and a large intrusion to the northwest, indicate slightly more mafic compositions than those in the Chisos Mountains region. Brownish regions reflecting low uranium content characterize mafic lava flows in the northeast and gabbro near the Mariscal Mountains (fig. 8-4). White regions in the Chisos Mountains region not associated with igneous rocks relate primarily to sediments shed from igneous rocks, as do the pink-orange regions around the Rosillos laccolith (Anderson, 2007). Other rock types can be identified with radioelement data through various classification methods (Duval, 2005). 


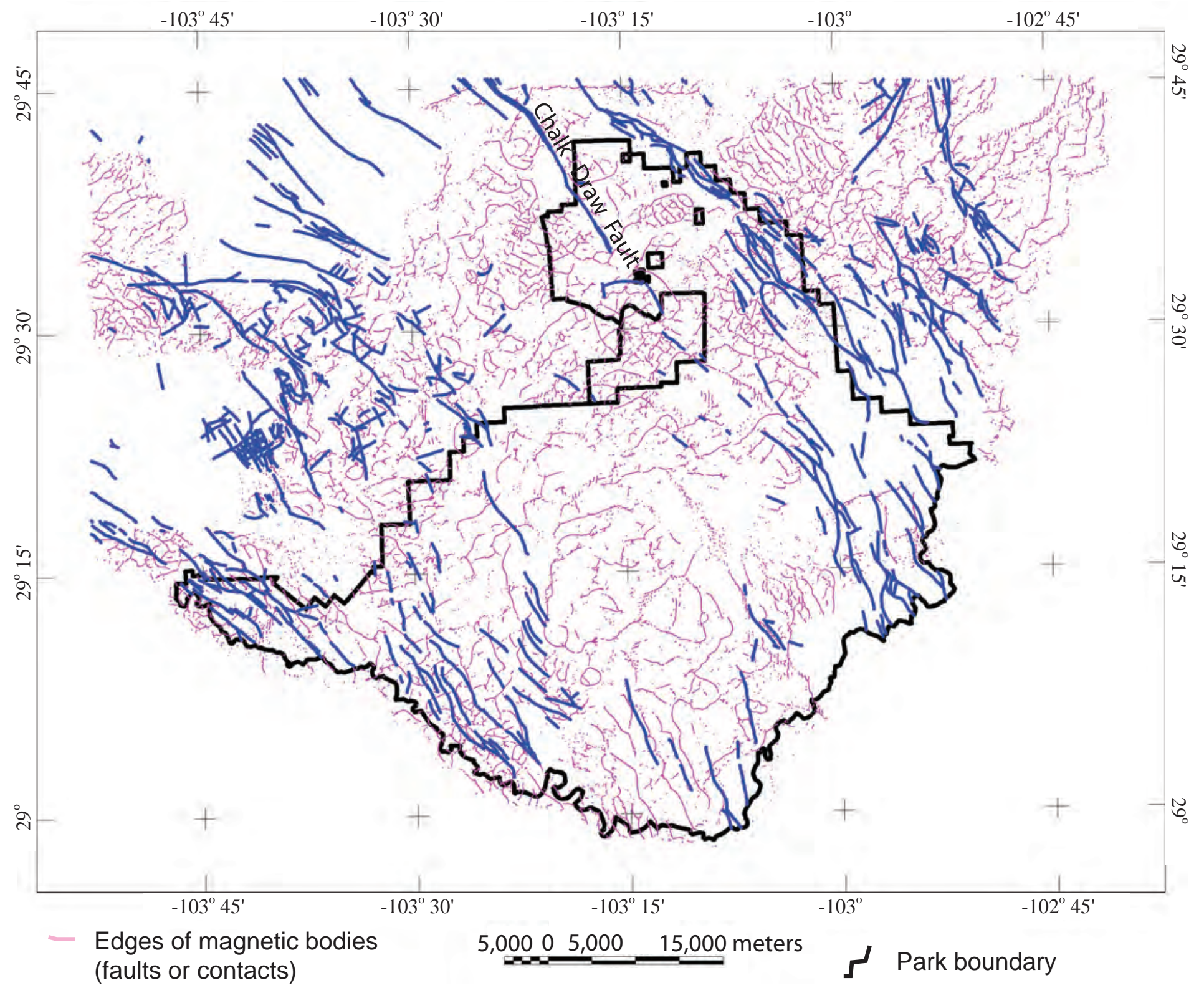

- Mapped faults

Figure 8-3. Mapped faults (Barnes, 1979) superimposed on the maxima of the horizontal gradient of the reduced to the pole magnetic anomaly (fig. 8-1). 


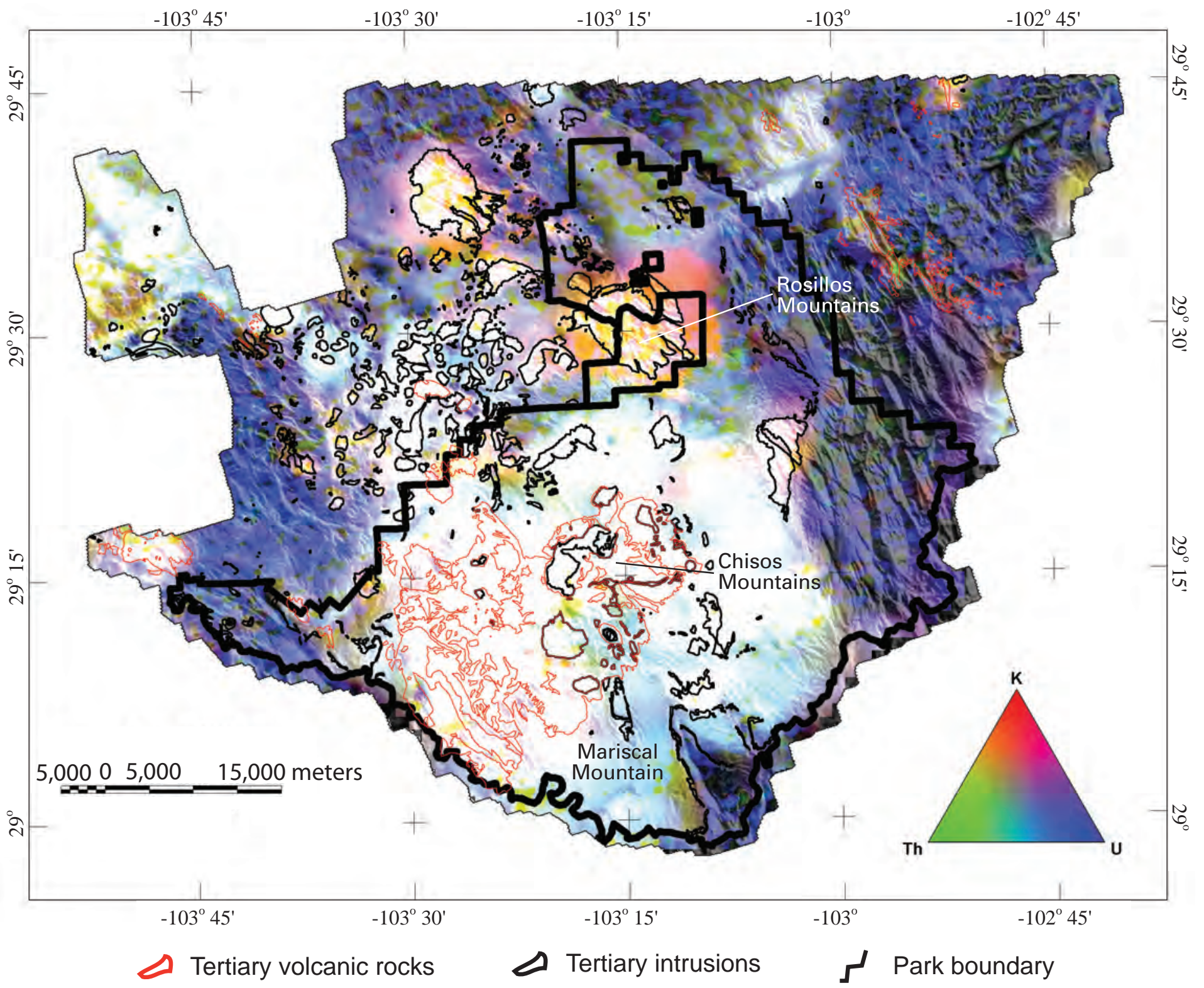

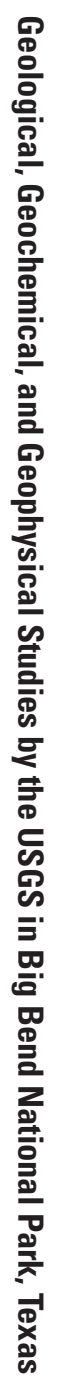

Figure 8-4. Color composite of potassium (red), thorium (green), and uranium (blue) superimposed on a grey shade map of the topography, with outlines of selected geologic units (Barnes, 1979). 


\section{References Cited}

Anderson, E.D., 2007, Integrating 2D geologic data with geophysics to generate a 3D geologic map of the Rosillos Mountains in Big Bend National Park, TX [abs.]: Geological Society of America Abstracts with Programs, v. 39, no. 6, p. 634.

Baranov, V., and Naudy, H., 1964, Numerical calculation of the formula of reduction to the magnetic pole: Geophysics, v. 29, p. 67-79.

Barnes, V.E., 1979, Emory Peak-Presidio sheet, Geologic atlas of Texas: University of Texas at Austin, Bureau of Economic Geology, 13 p.

Blakely, R.J., 1995, Potential theory in gravity and magnetic applications: Cambridge, U.K., University Press, 441 p.

Cordell, L., and Grauch, V.J.S., 1985, Mapping basement magnetization zones from aeromagnetic data in the San Juan basin, New Mexico, in Hinze, W. J., ed., The utility of regional gravity and magnetic anomaly maps: Society of Exploration Geophysicists, p. 181-197.

Drenth, B.J., and Finn, C.A., 2007, Aeromagnetic mapping of the structure of Pine Canyon caldera and Chisos Mountains intrusion, Big Bend National Park, Texas: Geological Society of America Bulletin, v. 119, p. 1,521-1,534.

Duval, J.S., 2005, Aerial gamma-ray, Landsat TM, and digital elevation data, Big Bend Area, Texas: U.S. Geological Survey Open-File Report 2005-1371, http://pubs.usgs.gov/ of/2005/1371/.

Phillips, J.D., 2000, Locating magnetic contacts-A comparison of the horizontal gradient, analytic signal, and local wavenumber methods: Society of Exploration Geophysicists Technical Program Expanded Abstracts, v. 21, p. 402-405. 


\section{Contributing Authors}

John E. Gray

editor, main point of contact

U.S. Geological Survey

Denver Federal Center

Box 25046, Mail Stop 973

Denver, C0 80225

jgray@usgs.gov

William R. Page

co-editor

U.S. Geological Survey

Denver Federal Center

Box 25046, Mail Stop 980

Denver, C0 80225

rpage@usgs.gov

Eric D. Anderson

U.S. Geological Survey

Denver Federal Center

Box 25046, Mail Stop 964

Denver, CO 80225

ericanderson@usgs.gov

Elizabeth Y. Anthony

Department of Geological Sciences

University of Texas at El Paso

500 University Ave.

El Paso, TX 79902

eanthony@geo.utep.edu

Margaret E. Berry

U.S. Geological Survey

Denver Federal Center

Box 25046, Mail Stop 980

Denver, C0 80225

meberry@usgs.gov

Robert G. Bohannon

U.S. Geological Survey

Denver Federal Center

Box 25046, Mail Stop 980

Denver, C0 80225

bbohannon@usgs.gov

Carol A. Finn

U.S. Geological Survey

Denver Federal Center

Box 25046, Mail Stop 964

Denver, C0 80225

cfinn@usgs.gov
Pamela A. Gemery-Hill*

U.S. Geological Survey

Denver Federal Center

Box 25046, Mail Stop 973

Denver, CO 80225

Eric C. Hellgren

Cooperative Wildlife Research Laboratory

Southern Illinois University at Carbondale

Carbondale, IL 62901

hellgren@siu.edu

David P. Krabbenhoft

U.S. Geological Survey

8505 Research Way

Middleton, WI 53562

dpkrabbe@usgs.gov

Andrew H. Manning

U.S. Geological Survey

Denver Federal Center

Box 25046, Mail Stop 964

Denver, C0 80225

amanning@usgs.gov

Daniel P. Miggins

U.S. Geological Survey

Denver Federal Center

Box 25046, Mail Stop 974

Denver, CO 80225

dmiggins@usgs.gov

Lisa A. Morgan

U.S. Geological Survey

Denver Federal Center

Box 25046, Mail Stop 973

Denver, C0 80225

Imorgan@usgs.gov

David P. Onorato

Fish and Wildlife Research Institute

Florida Fish and Wildlife Conservation Commission

Naples, FL 34104

dave.onorato@myFWC.com

Minghua Ren

Department of Geological Sciences

University of Texas at El Paso

500 University Ave.

El Paso, TX 79902

ren@geo.utep.edu 
W.C. Pat Shanks III

U.S. Geological Survey

Denver Federal Center

Box 25046, Mail Stop 973

Denver, C0 80225

pshanks@usgs.gov

Craig A. Stricker

U.S. Geological Survey

Denver Federal Center

Box 25046, Mail Stop 963

Denver, CO 80225

cstricker@usgs.gov

Peter M. Theodorakos

U.S. Geological Survey

Denver Federal Center

Box 25046, Mail Stop 973

Denver, C0 80225

ptheodor@usgs.gov

Kenzie J. Turner

U.S. Geological Survey

Denver Federal Center

Box 25046, Mail Stop 980

Denver, C0 80225

kturner@usgs.gov

Van S. Williams

U.S. Geological Survey

Denver Federal Center

Box 25046, Mail Stop 980

Denver, C0 80225

vwilliam@usgs.gov

* At time of publication, Pamela A. Gemery-Hill is no longer affiliated with the U.S. Geological Survey. Author can be contacted at pagemeryhill@aol.com 


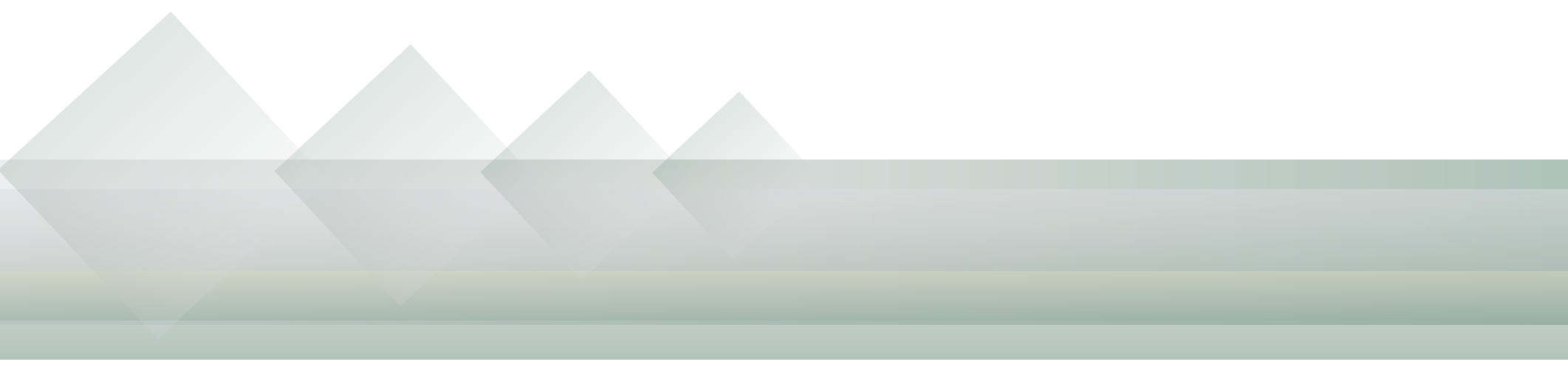


Publishing support provided by:

Denver Publishing Service Center

For more information concerning this publication, contact: Team Chief Scientist, USGS Central Mineral Resources

Box 25046, Mail Stop 973

Denver, CO 80225

(303)236-1562

Or visit the Central Mineral Resources Team Web site at: http://minerals.cr.usgs.gov/ 


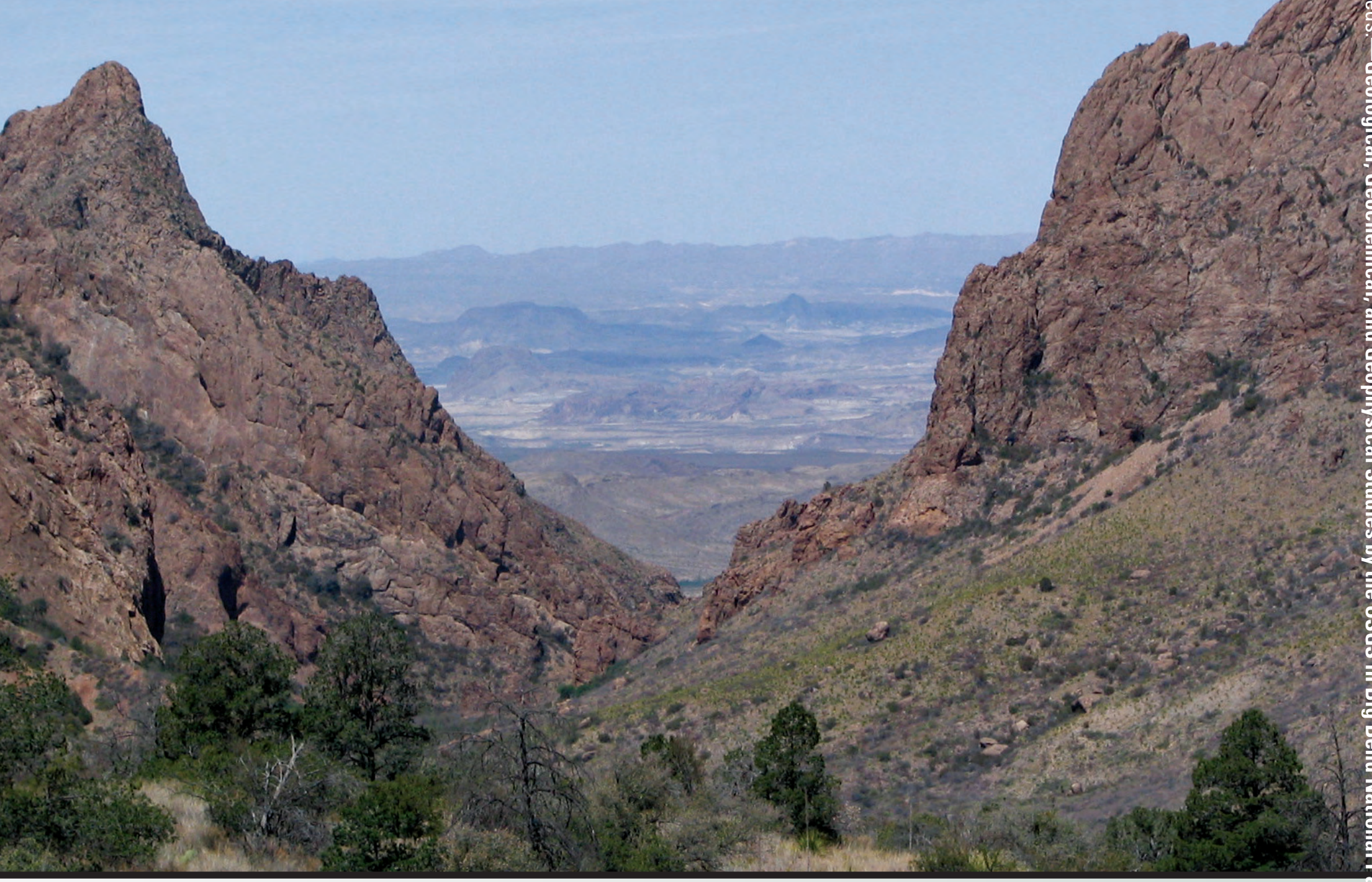

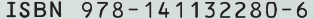

